FERNANDO HENRIQUE CORRÊA CUSTODIO

\title{
UMA NOVA ANÁLISE SOBRE OS BENEFÍCIOS POR INCAPACIDADE: ÊNFASE NA SUA EFETIVIDADE COMO DIREITO HUMANO FUNDAMENTAL SOCIAL
}

Dissertação de Mestrado

Orientador: Professor Titular Dr. Sérgio Pinto Martins

UNIVERSIDADE DE SÃO PAULO

FACULDADE DE DIREITO

São Paulo - SP

2016 


\title{
UMA NOVA ANÁLISE SOBRE OS BENEFÍCIOS POR INCAPACIDADE: ÊNFASE NA SUA EFETIVIDADE COMO DIREITO HUMANO FUNDAMENTAL SOCIAL
}

\begin{abstract}
Dissertação apresentada à Banca Examinadora do Programa de Pós-Graduação em Direito, da Faculdade de Direito da Universidade de São Paulo, como exigência parcial para a obtenção do título de Mestre em Direito, na área de concentração de Direito do Trabalho e da Seguridade Social, sob a orientação do Professor Titular Dr. Sérgio Pinto Martins.
\end{abstract}

UNIVERSIDADE DE SÃO PAULO

FACULDADE DE DIREITO

São Paulo - SP

2016 
Autorizo a reprodução e divulgação total ou parcial deste trabalho, por qualquer meio convencional ou eletrônico, para fins de estudo e pesquisa, desde que citada a fonte.

\section{Catalogação da Publicação}

Custodio, Fernando Henrique Corrêa

Uma nova análise sobre os benefícios por incapacidade: ênfase na sua efetividade como direito humano fundamental social / Fernando Henrique Corrêa Custodio. -- São Paulo: USP / Faculdade de Direito, 2016. $243 \mathrm{f}$.

Orientador: Professor Titular Dr. Sérgio Pinto Martins

Dissertação (Mestrado), Universidade de São Paulo, USP, Programa de Pós-Graduação em Direito, Direito do Trabalho e da Seguridade Social, 2016.

1. Direitos humanos fundamentais sociais. 2. Princípios jurídicos. 3. Força normativa da Constituição. 4. Benefício social. I. Martins, Sérgio Pinto. II. Título. 
BANCA EXAMINADORA

Orientador Prof. Dr. Sérgio Pinto Martins 
À minha esposa Anamaria, razão do meu viver.

Ao meu recém-chegado e já amado filho Felipe. 


\section{AGRADECIMENTOS}

Agradeço ao meu Orientador, Professor Doutor Sérgio Pinto Martins, pela confiança depositada em meus esforços e paciência para as diversas correções ao longo da elaboração desta dissertação.

Também agradeço aos Professores Doutores Francisco Jucá e Ari Possidônio Beltran, componentes de minha banca examinadora, pelos excelentes esclarecimentos prestados quando do exame de qualificação, que muito me auxiliaram no norteamento e concatenação dos argumentos utilizados ao longo desta dissertação.

Por fim, agradeço aos colegas de pós-graduação, especialmente ao colega Luciano Palhano, pelos profícuos debates sobre os mais diversos temas, que muito me auxiliaram. 
CUSTODIO, Fernando Henrique Corrêa. Uma nova análise sobre os benefícios por incapacidade: ênfase na sua efetividade como direito humano fundamental social. 2016. 243f. Mestrado - Faculdade de Direito, Universidade de São Paulo, São Paulo, 2016.

\section{RESUMO}

Estudo dos benefícios previdenciários por incapacidade sob o prisma dos direitos humanos fundamentais sociais, com enfoque na garantia de sua máxima efetividade possível em termos de concretização, como princípio jurídico. Importância cada vez maior do tema, tendo em vista o aumento de sua litigiosidade, atualmente responsável pelo maior número de ações ajuizadas e em trâmite junto aos Juizados Especiais Federais da Terceira Região. Utilização dos métodos dedutivo e interdisciplinar de estudo, com ênfase nos enfoques histórico, político, filosófico, social e jurídico. Análise dos direitos humanos fundamentais sob o prisma da Teoria Crítica (Escola de Frankfurt) e do pós-positivismo (neoconstitucionalismo concretista; força normativa da constituição), levando-se em conta sua evolução histórica, bem como a evolução dos modelos de Estado, dos ordenamentos jurídicos e da própria sociedade ao longo dos séculos. Conclusão pela existência de um regime jurídico único de proteção de todos os direitos humanos fundamentais, de nível constitucional, bem como de seu caráter universalizante, fruto de longo processo de lutas pelo reconhecimento do ser humano como sujeito de direitos e da sacralização da pessoa humana, alçada ao centro dos ordenamentos jurídicos estatais. Reflexos de tais constatações na via jurisdicional, mediante a garantia de plena justiciabilidade dos direitos humanos fundamentais, com ênfase nos direitos sociais. Inserção do direito a previdência social dentre os direitos humanos fundamentais sociais, com assento constitucional (art. 201, I). Necessidade de seu estudo a partir da análise das contingências sociais elencadas constitucionalmente e em lei como objeto de proteção estatal. Aglutinação das prestações previdenciárias em torno de cada contingência social, com a formação de um regime jurídico único de proteção. Enfoque na contingência social da incapacidade laboral decorrente de doença e/ou acidente, objeto do presente estudo. Aglutinação dos três benefícios previdenciários por incapacidade (aposentadoria por invalidez, auxílio-doença e auxílio-acidente) em um regime jurídico protetivo único, caracterizado pela fungibilidade ontológica entre eles. Necessidade de garantia da prestação adequada ao caso concreto, sem exigências de prévia definição acerca do grau e alcance da incapacidade laboral do trabalhador segurado. Reflexos de tais constatações sobre as demandas previdenciárias por incapacidade laboral, com ênfase na garantia da proteção jurisdicional ao direito humano fundamental social. Escopo principal de desenvolvimento de uma teoria geral voltada à proteção dos benefícios previdenciários por incapacidade, notadamente pela via jurisdicional, como medida de estímulo ao debate acadêmico e desenvolvimento destes estudos, com ganhos em termos de fundamentação e coerência. Fomento, outrossim, a uma análise sistemática e coerente de tais benefícios pelo Poder Judiciário, com o abandono da análise casuística e pontual levada a efeito até hoje.

Palavras-chave: Direitos humanos fundamentais sociais. Princípios jurídicos. Benefícios por incapacidade. Fungibilidade. Teoria crítica. Força normativa da constituição. Concretização. Efetividade dos direitos fundamentais. 
CUSTODIO, Fernando Henrique Corrêa. A new analysis of the incapacity benefits: emphasis on its effectiveness as a social fundamental human right. 2016. 243p. Mestrado Faculdade de Direito, Universidade de São Paulo, São Paulo, 2016.

\begin{abstract}
Study of the incapacity benefits through the prism of social fundamental human rights, with a focus on ensuring the maximum possible effectiveness in their implementation, as a legal principle. Growing importance of the issue, given the increase in their litigation, currently responsible for the largest number of lawsuits filed and pending with the Federal Special Courts of the Third Region. Use of deductive and interdisciplinary study methods, emphasizing the historical, political, philosophical, social and legal approaches. Analysis of fundamental human rights from the perspective of Critical Theory (Frankfurt School) and post-positivism (concretist neoconstitutionalism; normative force of the constitution), taking into account its historical evolution and the evolution of state models, of legal system and society itself over the centuries. Conclusion by the existence of a unified legal regime for the protection of all fundamental human rights, at constitutional level, as well as its universalizing character, as a result of long process of struggles for recognition of the human being as a subject of rights and the sacredness of the human person, raised to the center of state legal systems. Reflections of those findings in the judicial process, by ensuring full justiciability of fundamental human rights, with emphasis on social rights. Insertion of the right to social security among the social fundamental human rights, with constitutional provision (art. 201, I). Need for their study from the analysis of social contingencies listed constitutionally and in law as state protection object. Agglutination of social security benefits around each social contingency, with the formation of a unified legal regime of protection. Focus on social contingency of incapacity due to illness and/or accident, the present study object. Agglutination of the three incapacity benefits (disability retirement, sickness and accident allowance) in a unified protective legal regime, characterized by ontological fungibility between them. Need to ensure the appropriate benefit to the case, without requiring prior definition of the extent and scope of the incapacity of the insured worker. Reflections of such findings on the judicial claims for incapacity, emphasizing the guarantee of judicial protection to the social fundamental human right. Principal aim of developing a general theory focused on the protection of incapacity benefits, notably by judicial process, as a stimulus to the academic debate and development of these studies, with gains in terms of reasoning and coherence. Promoting, moreover, a systematic and coherent analysis of such benefits by the judiciary, with the abandonment of the casuistic and punctual analysis carried out to date.
\end{abstract}

Keywords: Social fundamental human rights. Legal principles. Incapacity benefits. Fungibility. Critical Theory. Normative force of the constitution. Concretion. Effectiveness of fundamental rights. 


\section{SUMÁRIO}

INTRODUÇÃO

\section{EVOLUÇÃO HISTÓRICA DOS DIREITOS HUMANOS FUNDAMENTAIS: AS} TRÊS DIMENSÕES

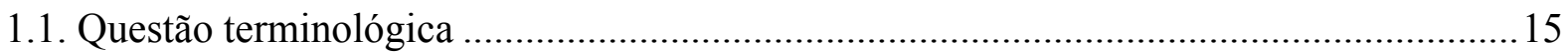

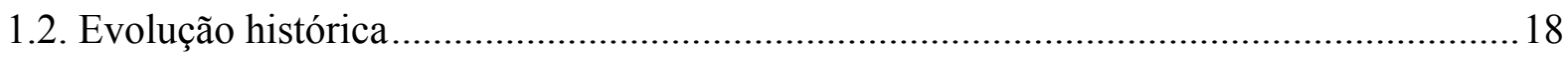

1.3. As três dimensões dos direitos humanos fundamentais (direitos de liberdade,

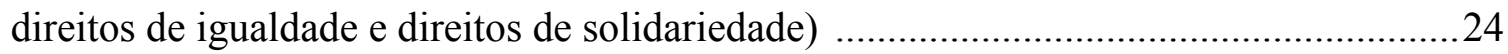

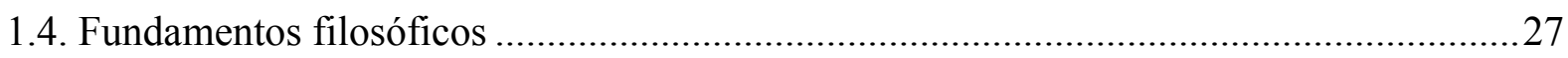

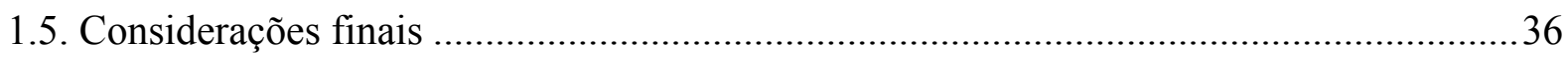

2. DOS DIREITOS SOCIAIS: CONCEITO, ABRANGENCIA (PLANOS INTERNACIONAL E INTERNO) E EFICÁCIA …...................................................... 38

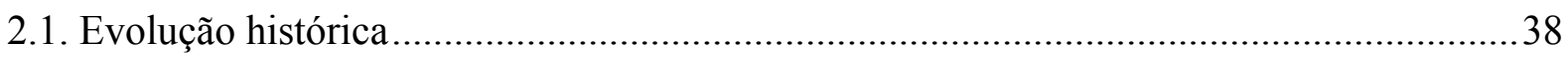

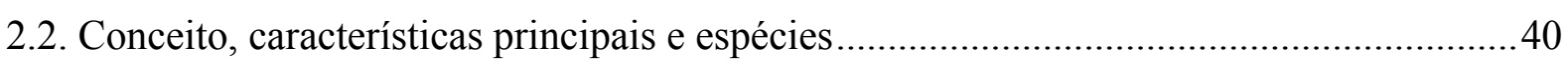

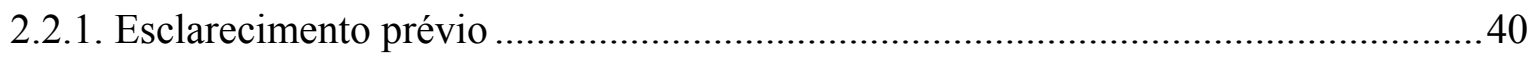

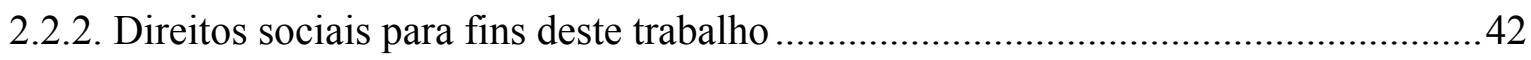

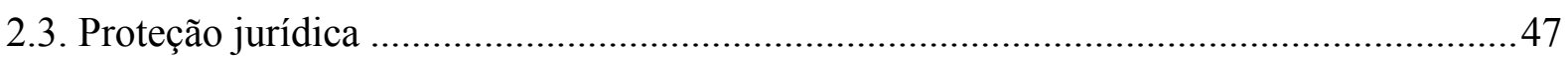

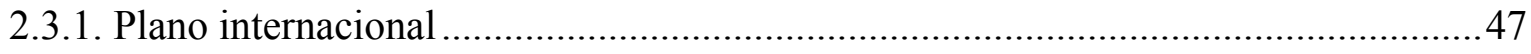

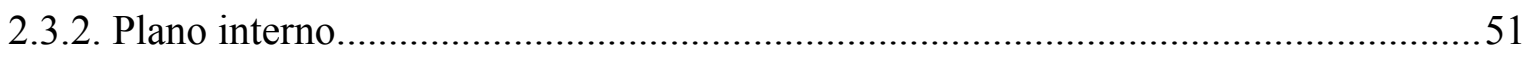

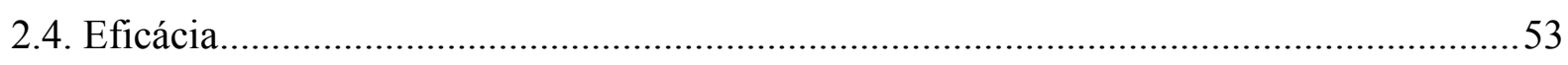

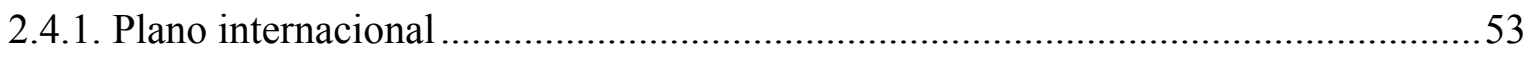

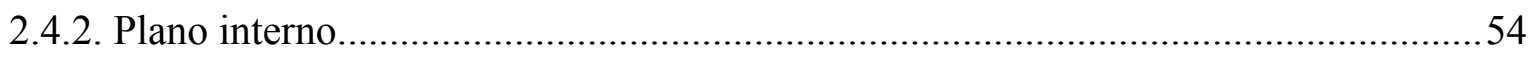

3. OS DIREITOS HUMANOS FUNDAMENTAIS COMO PREVISTOS E GARANTIDOS CONSTITUCIONALMENTE: A FORÇA NORMATIVA DA

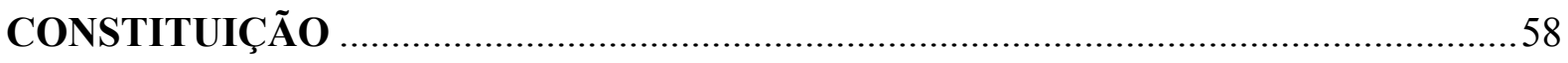

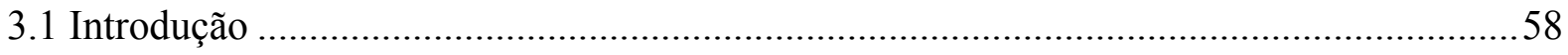

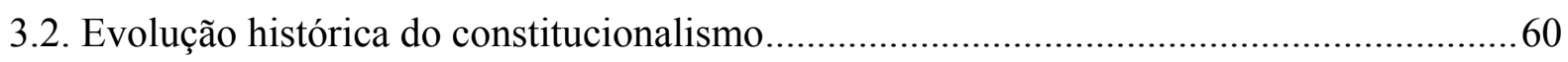

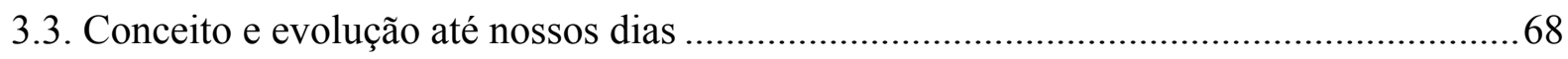

3.4. A evolução teórica do constitucionalismo: de um documento político para um documento dotado de força normativa - de Ferdinand Lassalle a Konrad Hesse .............72 
4. A FORÇA NORMATIVA DA CONSTITUIÇÃO E SEUS REFLEXOS SOBRE OS DIREITOS SOCIAIS: OS TEMAS DA FORÇA NORMATIVA DOS PRINCÍPIOS CONSTITUCIONAIS, DA DIGNIDADE DA PESSOA HUMANA, DA VEDAÇÃO DO RETROCESSO SOCIAL E DO DIREITO ADQUIRIDO

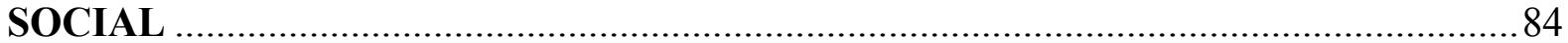

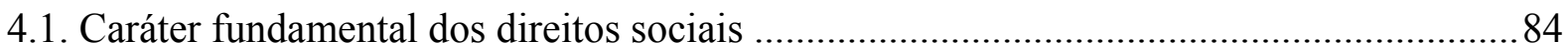

4.2. Mecanismos neoconstitucionais de garantia e eficácia dos direitos sociais ......................86

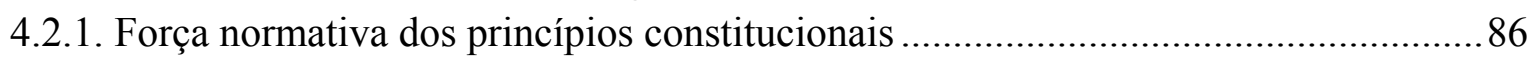

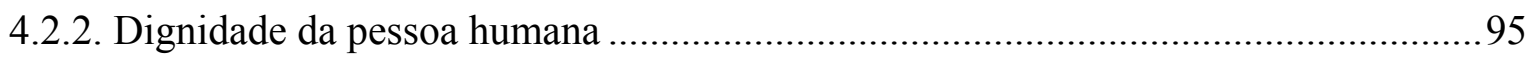

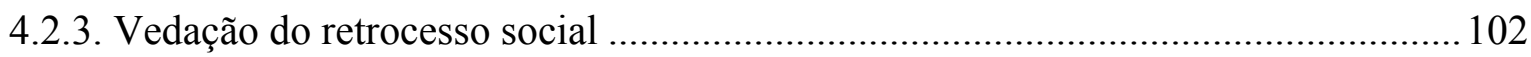

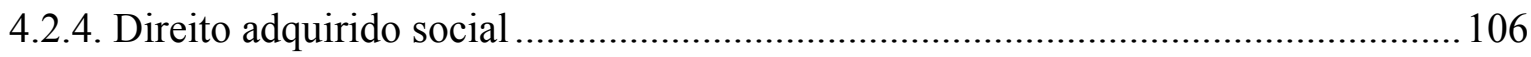

5. DIREITOS SOCIAIS E SUA PROTEÇÃO JURISDICIONAL: DO ATIVISMO JUDICIAL E DA RESERVA DO POSSÍVEL. DO FALSO PROBLEMA DA NÃO JUSTICIABILIDADE DAS CHAMADAS “POLÍTICAS PÚBLICAS" ...................... 110

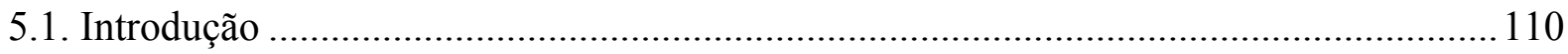

5.2. Direitos sociais sob o prisma restritivo das "políticas públicas": uma visão crítica....... 114

5.3. Rebatendo os principais argumentos contrários à legitimidade do Poder Judiciário em exercer o controle das "políticas públicas" ............................................................ 117

5.3.1. Da alegada violação ao princípio da separação dos poderes................................... 117

5.3.2. Da alegada violação ao princípio da igualdade ...................................................... 119

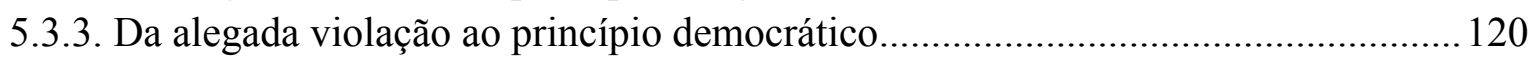

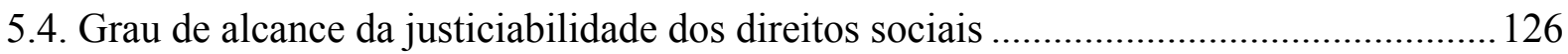

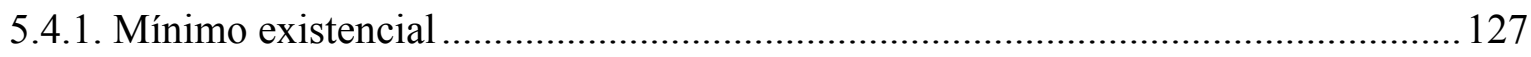

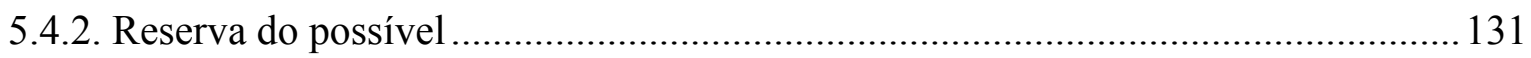

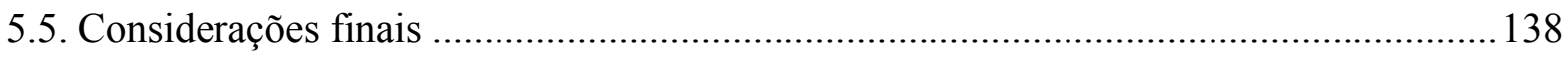

6. DA PREVIDÊNCIA SOCIAL COMO DIREITO HUMANO FUNDAMENTAL DE SEGUNDA DIMENSÃO (=direito social) VOLTADO À PROTEÇÃO DAS

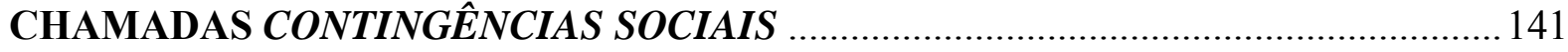

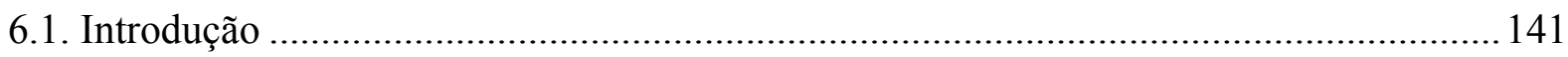

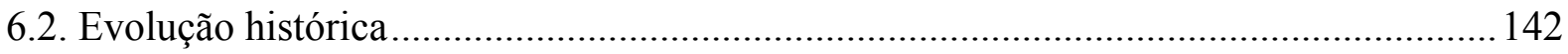

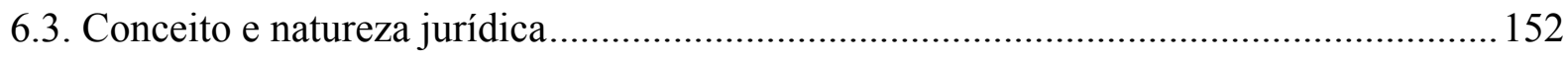

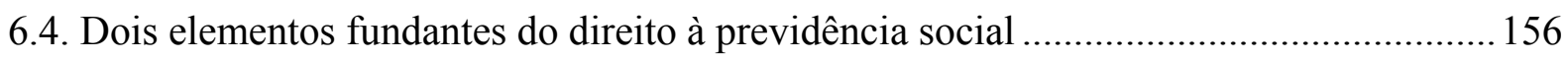

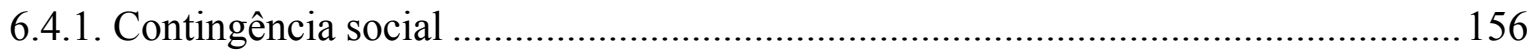

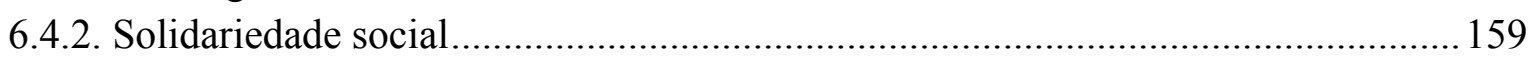

7. DAS CONTINGÊNCIAS SOCIAIS PROTEGIDAS PELO REGIME GERAL DE

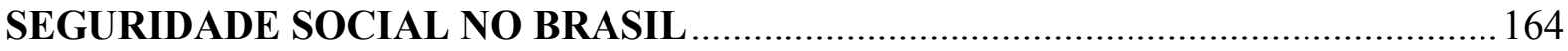

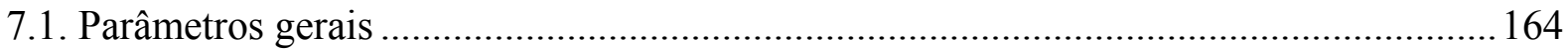

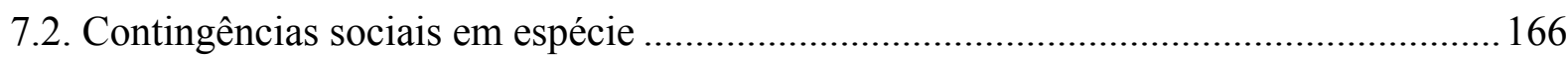

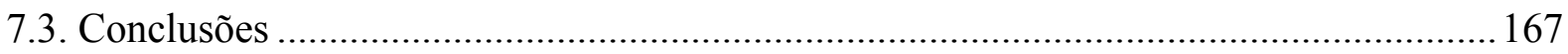


8. DA CONTINGÊNCIA SOCIAL DA INCAPACIDADE LABORAL E RESPECTIVOS BENEFÍCIOS PREVIDENCIÁRIOS 171

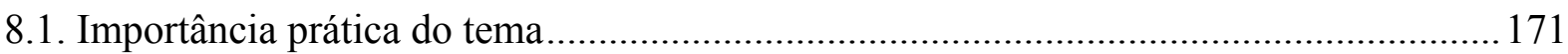

8.2. Da contingência social protegida: questão terminológica............................................. 173

8.3. Análise comparativa dos benefícios por incapacidade ............................................. 175

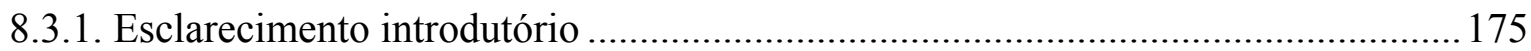

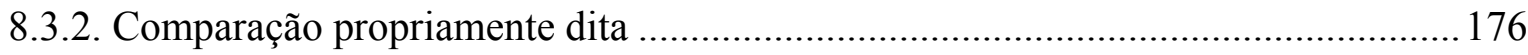

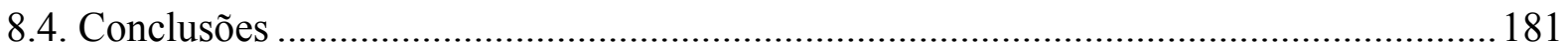

9. DA INCLUSÃO DO AUXÍLIO-ACIDENTE NO ROL DOS BENEFÍCIOS PREVIDENCIÁRIOS PAGOS EM RAZÃO DA CONSTATAÇÃO DA CONTINGÊNCIA SOCIAL DA INCAPACIDADE LABORAL ................................. 184

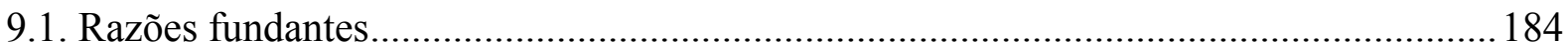

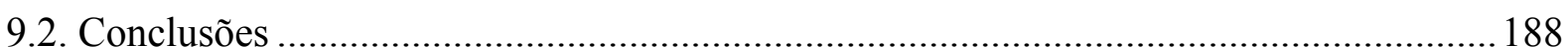

10. IDENTIDADE ONTOLÓGICA ENTRE OS BENEFÍCIOS PREVIDENCIÁRIOS POR INCAPACIDADE E SEU COROLÁRIO: DA FUNGIBILIDADE

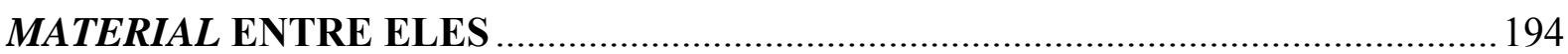

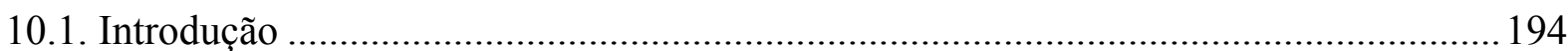

10.2. Da fungibilidade material entre os benefícios previdenciários por incapacidade laboral.

11. DA CONTINGÊNCIA SOCIAL DA INCAPACIDADE LABORAL E SUA TUTELA JURISDICIONAL: A MÁXIMA EFETIVAÇÃO POSSÍVEL DO

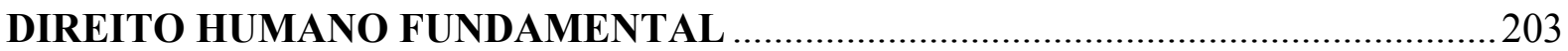

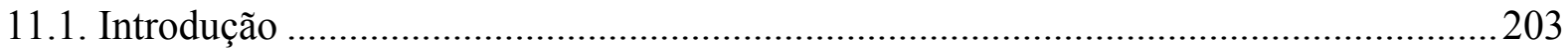

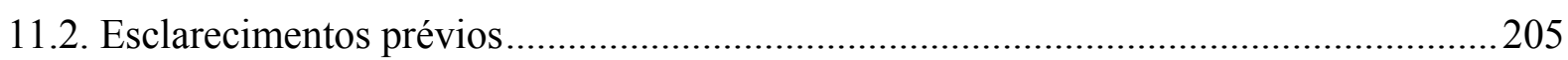

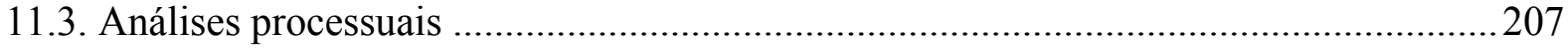

11.3.1. Direito à previdência social e pedido inicial .....................................................207

11.3.2. Direito à previdência social e princípio da congruência .....................................2212

11.3.3. Direito à previdência social e atividade probatória.............................................216

12. CONSIDERAÇÕES FINAIS DE ORDEM PROCESSUAL ........................................224

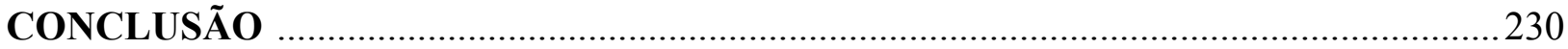

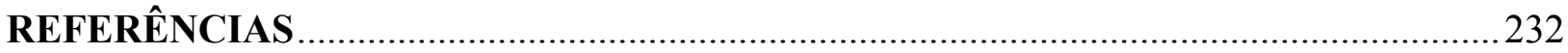




\section{INTRODUÇÃO}

Antes de adentrar na análise do objeto deste trabalho, reputo necessários alguns esclarecimentos iniciais.

A importância deste estudo está no desenvolvimento de uma análise científica acerca do modo pelo qual deve ser interpretado o regramento jurídico disciplinador dos benefícios previdenciários por incapacidade, como a maior demanda judicial atualmente existente junto aos Juizados Especiais Federais da Terceira Região ${ }^{1}$.

Busca-se, deste modo, disponibilizar aos operadores do Direito um arsenal técnicojurídico argumentativo coeso, profundo e sistemático acerca de tais benefícios, com ganhos em termos de rigor científico e disciplina no estudo da matéria, o que, com todo o respeito, não é o que tem ocorrido na doutrina majoritária e nos julgamentos a respeito do tema, notadamente aqueles erigidos em sede do Superior Tribunal de Justiça ${ }^{2}$.

$\mathrm{Na}$ atual quadra evolutiva, os benefícios previdenciários ainda são estudados de forma desvinculada das contingências sociais eleitas e protegidas constitucionalmente. Trata-se de um estudo separado de cada prestação, realizado de forma unitária, a partir das disposições legais disciplinadoras dos requisitos necessários à percepção de cada qual.

A análise atualmente realizada parte da prestação previdenciária prevista em lei para a fixação do sentido e alcance da proteção estatal, com grande limitação em termos de sua abrangência e ausência de preocupação com um estudo sistematizado, garantidor da supressão de lacunas e de incoerências internas quando da busca de soluções para os diversos casos concretos, de modo a se evitar o apontamento de soluções díspares para casos análogos.

Com todo o respeito, não é o método mais correto e útil para o estudo do tema, devendo ser realizada uma verdadeira inversão de perspectiva, estudando-se tais benefícios a partir da visão da previdência social como direito humano fundamental social, tendo como pedra de toque a noção de contingência social.

\footnotetext{
${ }^{1}$ Integrado pelos Estados de São Paulo e Mato Grosso do Sul.

${ }^{2}$ Tribunal de superposição responsável pela unificação de entendimento sobre a interpretação das normas jurídicas infraconstitucionais, logo, tendo a última palavra acerca da grande maioria das questões previdenciárias, disciplinadas, via de regra, pela legislação ordinária.
} 
Somente assim restará assegurada a máxima proteção possível a tal direito humano fundamental, protegido constitucionalmente, dentro de um regime jurídico único, altamente protetivo.

Uma análise possível a partir de tal perspectiva, com a criação de um verdadeiro regime jurídico único, altamente protetivo do direito à previdência social, será apresentada como objeto de estudo deste trabalho, que culminará com a análise dos reflexos de tal visão sobre os benefícios previdenciários por incapacidade em termos de máxima efetividade possível.

Em termos metodológicos, como o próprio título deixa transparecer, não por acaso, o processo argumentativo a ser desenvolvido na presente dissertação envolverá o método dedutivo, pelo qual se partirá da utilização e fundamentação racional de afirmações mais teóricas e genéricas, com base nas quais se promoverá um processo de aproximação gradual do objeto de estudo, propriamente dito, desta obra - os benefícios previdenciários por incapacidade -, culminando com sua análise final e o estabelecimento de um conjunto de conclusões, fundamentadas exatamente em todo este processo argumentativo-racional de aproximação do objeto de estudo.

Claro que um esforço racional-argumentativo de tal envergadura demanda a adoção de pontos de partida inquestionáveis (epistemológicos), que serão expostos ao longo dos temas analisados, juntamente com as razões pelas quais devem ser necessariamente adotados em um estudo de tal jaez.

Buscarei, portanto, não só fundamentar cada assunto tratado como indispensável para a análise em si do objeto de estudo do presente trabalho, mas também as razões pelas quais se adota uma específica análise, com a inclusão de certos temas (p.e.: estudo dos direitos humanos fundamentais sob a perspectiva de sua evolução histórica, tendo como pilares filosóficos a Teoria Crítica e a sacralização da pessoa humana como sujeito de direitos, estudo do pós-positivismo e do neoconstitucionalismo dentro de sua vertente concretista [força normativa da Constituição] e como tais teorias jurídicas influenciam sobremaneira a forma de entender e interpretar os direitos humanos fundamentais sociais, neles incluído o direito à previdência social; estudo dos diversos mecanismos de proteção e efetivação jurídico-constitucional dos direitos humanos fundamentais, como a supremacia da Constituição, a força normativa dos princípios constitucionais, as cláusulas pétreas, a aplicação imediata das normas garantidoras de tais direitos, a vedação do retrocesso social, o direito adquirido social, dentre outros; estudo dos principais temas envolvendo o 
problema da proteção dos direitos humanos fundamentais sociais na esfera jurisdicional, como a justiciabilidade de tais direitos, a legitimidade do Poder Judiciário para o controle de políticas públicas sociais, o mínimo existencial e a reserva do possível) e a exclusão de outros (cortes metodológicos que envolvem a não discussão, nesta obra científica, de temas como a classificação das normas jurídicas constitucionais, o papel e a estruturação de cada modelo de Estado em sua evolução histórica, uma análise comparativa entre os diversos modelos constitucionais [jusnatural, positivista, pós-positivista], as diversas classificações acerca dos direitos humanos fundamentais, seu caráter universal ou relativo, o sistema de seguridade social brasileiro e suas características principais, dentre outros temas que não guardam uma relação direta e umbilical com o objeto deste trabalho).

O presente estudo parte da noção fulcral de que o direito à previdência social é espécie integrante dos direitos humanos fundamentais. Logo, tem seu início exatamente com o estudo dos próprios direitos humanos fundamentais, mediante a adoção de um viés de análise que conjuga os enfoques histórico-político-filosófico-jurídico, com prevalência do binômio Teoria Crítica (enfoque filosófico)/pós-positivismo (enfoque jurídico) (capítulos 1 a 3 ).

As primeiras conclusões nodais dirão respeito à necessidade de se focar os direitos humanos fundamentais sob o prisma de seu caráter evolutivo, necessariamente universalizante, inserido em um regime jurídico único, altamente protetivo, de nível constitucional, voltado à máxima eficácia possível dos direitos inseridos em seu conceito, inclusive, em termos de controle e efetivação pela via jurisdicional (capítulos 4 e 5).

Em seguida, se repetirá o mesmo processo teórico-argumentativo, agora tendo por objeto o direito humano fundamental específico à previdência social, chegando-se às mesmas conclusões: existência de um regime jurídico único de proteção do direito à previdência social, de nível constitucional, voltado à sua efetividade, com pleno controle jurisdicional (capítulos 6 e 7).

Por fim, agora em análise específica do objeto propriamente dito deste estudo, qual seja, os benefícios previdenciários por incapacidade laboral, como decorrência inexorável das análises e conclusões previamente levadas a efeito, também se chegará às mesmas conclusões: existência de um regime jurídico único protetivo da contingência social da incapacidade laboral, unificador dos três benefícios por incapacidade previstos em lei (aposentadoria por invalidez, auxílio-doença e auxílio-acidente), caracterizador de sua fungibilidade material, a moldar a forma de interpretação das disposições legais 
disciplinadoras de cada qual, inclusive com inovações na forma de análise e conclusões acerca das principais questões atuais a envolver tais benefícios (padronização dos requisitos legais, inclusão do auxílio-acidente no rol dos benefícios previdenciários por incapacidade, sua identidade ontológica e o corolário da fungibilidade material) (capítulos 8 a 10).

Nos dois capítulos finais, o sistema jurídico protetivo de tais benefícios por incapacidade desenvolvido neste estudo científico passará por um teste empírico, que levará em consideração as principais questões processuais e jurisprudenciais relacionadas ao tema, sacando-se as conclusões finais, de ordem prática, decorrentes do emprego do arsenal teórico aqui desenvolvido sobre tais questões fáticas (capítulos 11 e 12).

Todos os argumentos utilizados e desenvolvidos ao longo deste estudo terão um único fio condutor, a saber: a busca da máxima efetivação ${ }^{3}$ possível do direito humano fundamental à previdência social, dentro da seara das prestações decorrentes da contingência social da incapacidade laboral.

De se observar que o fio condutor desta obra reflete fielmente a linha de pesquisa eleita pela pós-graduação da USP no campo do Direito do Trabalho e da Seguridade Social, qual seja, os "Direitos Sociais no contexto dos Direitos Humanos", mais especificamente dentro da linha de projetos acadêmicos relacionados "A previdência, a assistência a saúde e a solidificação da dignidade humana", refletindo também alguns aspectos da linha relacionada "A eficiência dos institutos, normas e princípios de direito interno, comunitário e internacional do trabalho e a efetivação dos direitos humanos", sob a perspectiva do direito humano fundamental à previdência social.

O objetivo final será a construção de um sistema argumentativo substancial que justifique de forma robusta as conclusões a serem lançadas ao final de cada capítulo e da própria dissertação, de modo que elas surjam como decorrências necessárias e imprescindíveis dos argumentos lançados no início do trabalho.

Acredito que, assim, o estudo ganha em racionalidade, profundidade e densidade nas fundamentações necessárias às conclusões que serão sacadas ao longo do estudo, contribuindo de forma efetiva para a evolução do debate tanto no seu âmbito teórico $e$ abstrato - os direitos humanos fundamentais - quanto no seu âmbito mais específico $e$

\footnotetext{
${ }^{3}$ Tal expressão ("efetivação") deve ser entendida ao longo desta obra como sinônimo de "concretização", ou seja, de realização do direito em favor de determinada pessoa em dado caso concreto.
} 
concreto - os benefícios por incapacidade e seu caráter de fungibilidade material, fomentado pelo regime jurídico básico comum.

Como se trata de um estudo voltado à busca da máxima efetivação possível do direito humano fundamental à previdência social, especificamente na seara dos benefícios previdenciários por incapacidade, com a análise das principais celeumas atuais acerca do sentido e alcance de tal proteção estatal, optei por inserir as diversas conclusões e soluções no final de cada capítulo relacionado a cada questão abordada (itens 1.5, 5.5, 7.3, $8.4,9.2,10.2,11.3$ e subitens e 12). Isso por razões metodológicas, respeitando a pertinência temática entre as exposições e fundamentações apresentadas ao longo de cada capítulo e as conclusões a ele relacionadas.

Em virtude do relativamente grande número de conclusões apresentadas acerca dos temas analisados, sua inserção em um capítulo único, desvinculado das razões e argumentações justificantes de cada assunto, certamente geraria confusão e perplexidade, com sérios prejuízos à unidade e coerência nos estudos, o que justifica sua classificação e inserção tópica de acordo com cada tema estudado, ao final de cada capítulo.

De qualquer sorte, que não se perca de vista a conclusão nodal e objetivo primordial deste trabalho: o estudo da previdência social, com ênfase nos benefícios previdenciários por incapacidade, sob a perspectiva da Constituição, como direito humano fundamental social, dotado de grande carga eficacial, com a constituição de um regime jurídico próprio, altamente protetivo, balizado por teorias jurídicas e construções filosóficas utilizadas ao longo deste estudo como pilares fundantes da busca de sua máxima efetividade possível, seja em termos de beneficiários, seja em termos de contingências sociais abrangidas pela proteção estatal. 


\section{EVOLUÇÃO HISTÓRICA DOS DIREITOS HUMANOS FUNDAMENTAIS: AS TRÊS DIMENSÕES}

\subsection{Questão terminológica}

O ponto de partida imprescindível para um estudo científico que verse sobre "Direitos Humanos Fundamentais" é a análise de sua origem e evolução ao longo da história, uma vez que se trata de tema com raízes longínquas e profundas, que antecedem o próprio surgimento de sistemas jurídicos, sociais, políticos e econômicos, coincidindo quase que com o próprio surgimento do homem enquanto raça, além de interferir de forma decisiva na conformação e modificação de cada um desses sistemas.

Antes disso, porém, analisarei em rápidas pinceladas a questão inicial do assunto em voga, que é a terminológica.

Ou seja: qual o melhor conceito a ser utilizado para se falar, em termos científicos, sobre direitos endereçados a todo e qualquer ser humano, de caráter fundamental?

No atual estágio doutrinário de discussão, existe uma certa convergência ao redor de três principais conceitos utilizados: i) direitos do homem; ii) direitos humanos; iii) direitos fundamentais.

Também é relativamente uniforme o entendimento que se tem em relação à definição e campo de utilização de cada qual: i) por "direitos do homem" deve-se entender aqueles direitos inerentes à condição humana, sejam eles garantidos ou não por sistemas jurídicos estatais; ii) já a expressão "direitos humanos” é utilizada quando se faz referência àquele rol de direitos garantidos dentro da Ordem Jurídica Internacional, notadamente pela via dos Tratados e Convenções Internacionais; iii) por fim, o conceito "direitos fundamentais" diz respeito àqueles direitos do homem garantidos dentro de cada ordem jurídica interna, constituída por cada Estado Soberano ${ }^{4}$.

\footnotetext{
${ }^{4}$ Para um estudo mais aprofundado acerca das terminologias utilizadas pelos mais diversos doutrinadores acerca do assunto, confira-se a obra de Ingo Wolfgang Sarlet intitulada A eficácia dos direitos fundamentais. 8. ed. Porto Alegre: Livr. do Advogado, 2007, em seu capítulo inicial, que trata da "A problemática da delimitação conceitual e da definição na seara terminológica: a busca de um consenso", p. $33-42$.
} 
Bastante elucidativo é o escólio de Ingo Wolfgang Sarlet, ao discorrer sobre os três conceitos em voga:

\begin{abstract}
Em que pese sejam ambos os termos ('direitos humanos' e 'direitos fundamentais') comumente utilizados como sinônimos, a explicação corriqueira e, diga-se de passagem, procedente para a distinção é de que o termo 'direitos fundamentais' se aplica para aqueles direitos do ser humano reconhecidos e positivados na esfera do direito constitucional positivo de determinado Estado, ao passo que a expressão 'direitos humanos' guardaria relação com os documentos de direito internacional, por referir-se àquelas posições jurídicas que se reconhecem ao ser humano enquanto tal, independentemente de sua vinculação com determinada ordem constitucional, e que, portanto, aspiram à validade universal, para todos os povos e tempos, de tal sorte que revelam um inequívoco caráter supranacional (internacional).
\end{abstract}

De minha parte, não obstante entenda o critério utilizado por Ingo Wolfgang Sarlet para a separação dos três conceitos, qual seja, o da "concreção positiva", discordo desta separação, já que tal elemento de discrímen, com todo o respeito, não possui utilidade prática.

Ao contrário, acaba por criar dois sistemas estanques e aparentemente incomunicáveis de direitos da pessoa humana, o que gera uma situação de maior restrição e menor eficácia a tais direitos, já que cada qual deveria constar em ambos os sistemas para que houvesse uma proteção efetiva e maximizada.

Tal solução não observa o caráter de complementaridade entre os sistemas jurídicos internacional e interno (estatal) de direitos da pessoa humana, tampouco a própria razão de ser de tais sistemas, que é exatamente a proteção da pessoa humana como sujeito de direitos.

Também não observa a evolução histórica desses direitos, tampouco as características comumente atribuídas a tal feixe de direitos, o que será abordado mais adiante.

A meu ver, para a designação desse feixe de direitos, voltados ao ser humano como sujeito de direitos de índole fundamental, deve ser utilizada única e exclusivamente a expressão "direitos humanos fundamentais", que bem sintetiza os dois caracteres

\footnotetext{
${ }^{5}$ SARLET, Ingo Wolfgang. A eficácia dos direitos fundamentais, cit., p. 35-37.

${ }^{6}$ Id. Ibid., p. 38. Por ele, "o termo 'direitos humanos' se revelou conceito de contornos mais amplos e imprecisos que a noção de direitos fundamentais, de tal sorte que estes possuem sentido mais preciso e restrito, na medida em que constituem o conjunto de direitos e liberdades institucionalmente reconhecidos e garantidos pelo direito positivo de determinado Estado, tratando-se, portanto, de direitos delimitados espacial e temporalmente, cuja denominação se deve ao seu caráter básico e fundamentador do sistema jurídico do Estado de Direito”.
} 
essenciais de tais direitos: são direitos positivados da pessoa humana, de índole fundamental, ou seja, inseridos no ápice dos sistemas jurídicos internacional e interno (estatal).

Em assim sendo, basta a positivação de dado direito endereçado ao ser humano em apenas um dos sistemas jurídicos, para que ele receba a denominação de "direito humano fundamental"7, com todas as garantias e consequências jurídicas daí advindas em termos de proteção da pessoa humana. Não obstante concorde com Ingo Wolfgang Sarlet no tocante ao maior grau de eficácia de tais direitos no plano interno, se comparado ao plano internacional, no atual estágio de desenvolvimento da humanidade.

De qualquer sorte, será a expressão "direitos humanos fundamentais" que adotarei para efeitos do presente estudo, e que a meu ver melhor traduz o regime jurídico altamente protetivo da pessoa humana, alçado à condição de pilar dos sistemas jurídicos modernos, a ser abordado a seguir.

A corroborar a definição e terminologia a ser por mim utilizada ${ }^{8}$, socorro-me do escólio de Jorge Miranda, para quem os direitos humanos fundamentais correspondem a "toda a posição jurídica subjectiva das pessoas enquanto consagrada na Lei Fundamental"'.

Neste ponto, reputo de extrema relevância salientar que os direitos humanos fundamentais, em razão de sua importância fulcral nos sistemas jurídicos ocidentais, possuem um duplo caráter: i) configuram direitos públicos subjetivos do cidadão, exercitáveis em face do Estado e dos demais cidadãos; ii) possuem uma faceta objetiva, servindo como instrumentos e garantias viabilizadoras do exercício de direitos individuais fundamentais.

Assim é que, dentre o extenso rol de direitos humanos fundamentais, encontrar-seão direitos individuais exercitáveis pelos cidadãos de imediato (p.e.: liberdade religiosa, liberdade de expressão, liberdades públicas em geral), mas também será fácil identificar todo um instrumental viabilizador e garantidor do gozo desses direitos públicos subjetivos

\footnotetext{
${ }^{7}$ Expressão utilizada, dentre outros, por Alexandre de Moraes, em Direitos humanos fundamentais. 9. ed. São Paulo: Atlas, 2011 e por Manoel Gonçalves Ferreira Filho, em homônima Direitos humanos fundamentais. 13. ed. São Paulo: Saraiva, 2011.

${ }^{8}$ José Afonso da Silva utiliza a expressão "direitos fundamentais da pessoa humana", salientando exatamente as expressões "fundamentais" e "pessoa humana", que a seu ver bem sintetizam os caracteres mais importantes de tais direitos - a meu ver, com razão -, em sua obra Curso de direito constitucional positivo. 34. ed. São Paulo: Malheiros Ed., 2011, valendo conferir, a propósito, a passagem contida nas p. $175-179$.

${ }^{9}$ MIRANDA, Jorge. Manual de direito constitucional. 3. ed. Coimbra: Coimbra Ed., 2000. v. 4, p. 8-9.
} 
(p.e.: direito de ação, os remédios constitucionais do mandando de segurança e do habeas corpus, dentre outros).

Tal observação é importante para que não se pense que sob o rótulo "direitos humanos fundamentais" existem unicamente direitos públicos subjetivos, sendo os mesmos integrados também por instrumentos e mecanismos garantidores de tais direitos ${ }^{10}$.

\subsection{Evolução histórica}

No tocante à evolução histórica dos direitos humanos fundamentais, deve-se salientar desde já que sua enorme relevância se dá pelo fato de que, desde a antiguidade, já existia uma preocupação do homem em garantir um rol mínimo de direitos que lhe assegurasse uma existência digna e com segurança.

Evidentemente que, nos primórdios, as pessoas agraciadas com tais direitos representavam uma ínfima minoria composta pela nobreza e governantes, não sendo demais relembrar que, mesmo na Grécia antiga, a população era formada em sua esmagadora maioria por escravos, que eram considerados meros objetos apropriáveis e negociáveis (não cidadãos).

Assim é que, segundo o entendimento reinante dentre os estudiosos do assunto, já se verifica desde o Código de Hamurabi, datado aproximadamente de 1.800 a.C., a existência de regras voltadas à garantia de um mínimo de direitos em favor da pessoa humana.

Também na Grécia antiga, conforme já mencionado, a existência de direitos e garantias mínimos em favor dos cidadãos era tema recorrente dentre os filósofos, valendo relembrar a clássica obra de Sófocles intitulada “Antígona”, onde se defende a existência

\footnotetext{
${ }^{10}$ Confira-se, a propósito, escólio de Konrad Hesse: "Nos direitos fundamentais da Lei Fundamental unem-se, distintamente acentuadas e, muitas vezes, em passagens correntes, várias camadas de significado. Por um lado, eles são direitos subjetivos, direitos do particular, e precisamente, não só nos direitos do homem e do cidadão no sentido restrito (por exemplo, artigo $3^{\circ}, 4^{\circ}, 5^{\circ}, 8^{\circ}, 9^{\circ}$, da Lei Fundamental), mas também lá onde eles, simultaneamente, garantem um instituto jurídico ou a liberdade de um âmbito de vida (por exemplo, artigo $6^{\circ}$, alínea 1, 14, alínea $1,5^{\circ}$, alínea 3, da Lei Fundamental). Por outro, eles são elementos fundamentais da ordem objetiva da coletividade. Isso é reconhecido para garantias, que não contêm, em primeiro lugar, direitos individuais, ou, que em absoluto, garantem direitos individuais, não obstante estão, porém, incorporadas no catálogo de direitos fundamentais da Constituição (por exemplo, artigo $7^{\circ}$, alínea 1 , alínea 3, frase 1 e 2, alínea 5, da Lei Fundamental). Vale também para aqueles direitos fundamentais que são organizados, em primeiro lugar, como direitos subjetivos". HESSE, Konrad. Elementos de direito constitucional da República Federal da Alemanha. Tradução da 20. ed. alemã. Porto Alegre: Sergio Antonio Fabris, 1998. p. 228-229. Para maior aprofundamento de cada um dos aspectos (subjetivo e objetivo) dos direitos humanos fundamentais, confira-se, na mesma obra, p. 230-246.
} 
de normas superiores em favor dos cidadãos, que não poderiam ser violadas sequer pelos governantes. $\mathrm{O}$ mesmo se pode dizer acerca da civilização romana ${ }^{11}$.

Foi a Magna Charta Libertatum, assinada em 1215 pelo Rei João Sem-Terra, da Inglaterra, que inaugurou o rol de documentos onde se verifica a existência de um sistema coordenado de direitos e garantias voltado à proteção dos cidadãos - no caso, somente a nobreza e o clero -, valendo lembrar que tal documento foi assinado em um momento histórico onde a nobreza se revoltou contra a excessiva cobrança de impostos por parte do rei, sendo tal documento eminentemente um limitador do poder real ${ }^{12}$.

A partir desse ponto, e já adentrando na Idade Média, a evolução histórica dos direitos humanos fundamentais se triparte, com três desenvolvimentos que se somam na busca da conformação e sedimentação da ideia de direitos inerentes à pessoa humana: i) o catolicismo, que prega a igualdade entre os homens e a semelhança entre Deus e o homem (imago Dei), tendo como grande expoente Santo Tomás de Aquino; ii) os diversos documentos garantidores de direitos individuais à pessoa humana produzidos na Inglaterra, dentre eles a Petition of Right (1628), o Habeas Corpus Act (1679), a Bill of Rights (1689) e, finalmente, o Act of Settlement (1701), todos eles voltados, em última análise, ao aumento paulatino da limitação do poder real em face dos cidadãos (ampliação dos direitos de liberdade); iii) os forais e cartas de franquia, documentos outorgados pelos reis e senhores feudais garantidores de direitos em favor de certos grupos de pessoas, típicos da

\footnotetext{
${ }^{11}$ Resumo interessante acerca desta fase inicial de preocupação com a existência de direitos inerentes ao homem, ainda sem qualquer positivação e cuidado de sistematização, é dado por Alexandre de Moraes: “A origem dos direitos individuais do homem pode ser apontada no antigo Egito e Mesopotâmia, no terceiro milênio a.C., onde já eram previstos alguns mecanismos para proteção individual em relação ao Estado. O Código de Hammurabi (1690 a.C.) talvez seja a primeira codificação a consagrar um rol de direitos comuns a todos os homens, tais como a vida, a propriedade, a honra, a dignidade, a família, prevendo, igualmente, a supremacia das leis em relação aos governantes. A influência filosófico-religiosa nos direitos do homem pôde ser sentida com a propagação das ideias de Buda, basicamente sobre a igualdade de todos os homens (500 a.C.). Posteriormente, já de forma mais coordenada, porém com uma concepção ainda muito diversa da atual, surgem na Grécia vários estudos sobre a necessidade da igualdade e liberdade do homem, destacando-se as previsões de participação política dos cidadãos (democracia direta de Péricles); a crença na existência de um direito natural anterior e superior às leis escritas, defendida no pensamento dos sofistas e estóicos (por exemplo, na obra Antígona - 441 a.C. -, Sófocles defende a existência de normas não escritas e imutáveis, superiores aos direitos escritos pelo homem). Contudo, foi o Direito romano que estabeleceu um complexo mecanismo de interditos visando tutelar os direitos individuais em relação aos arbítrios estatais. A Lei das doze tábuas pode ser considerada a origem dos textos escritos consagradores da liberdade, da propriedade e da proteção aos direitos do cidadão". MORAES, Alexandre de. Direitos humanos fundamentais, cit., p. 6.

${ }^{12} \mathrm{~A}$ referência à Magna Charta Libertatum como o primeiro documento garantidor e sistematizador de direitos humanos fundamentais, mesmo que limitados a uma ínfima minoria (nobreza e clero) e relacionados unicamente a direitos e garantias individuais de liberdade, é quase que unânime na doutrina pátria, valendo conferir: i) MORAES, Alexandre de. Direitos humanos fundamentais, cit., p. 7; ii) MARMELSTEIN, George. Curso de direitos fundamentais. 4. ed. São Paulo: Atlas, 2013. p. 27-31; iii) FIRMINO, Nelson Flávio. Curso de direitos fundamentais. Curitiba: Juruá, 2013. p. 138-142; iv) FERREIRA FILHO, Manoel Gonçalves. op. cit., p. 29-30.
} 
lógica corporativa da época, segundo a qual a pessoa humana não era reconhecida em sua individualidade, mas como parte integrante de um corpo coletivo (corporações de ofício, castas, grupos sociais).

Importante salientar que a Idade Média e todos os movimentos supra mencionados nela ocorridos prepararam caminho para o surgimento dos direitos humanos fundamentais no formato atualmente conhecido, promovendo um deslocamento e uma ampliação graduais no seu âmbito de abrangência, tanto em termos de número de direitos garantidos, quanto de pessoas sob a sua proteção.

Assim é que, se em um primeiro momento ainda não se falava em cidadão no formato individualizado e abrangente atual, sendo que a pessoa estava sempre atrelada a uma corporação de ofício, ou a um título nobiliárquico (caso da nobreza e do clero), a série de documentos elaborados e de teorias desenvolvidas em prol da proteção dos direitos do homem - visto como imagem e à semelhança de Deus - acabou por culminar em uma fase de grandes transformações, ocorridas no período entre o fim do Século XVIII e início do Século XIX.

Transformações: i) econômicas - passagem da economia baseada nas corporações de ofício, trocas e títulos nobiliárquicos para a economia capitalista; ii) sociais surgimento da burguesia; iii) políticas - transformação do Estado Absolutista em Estado de Direito, com poderes limitados e supremacia da lei; iv) filosóficas - teorias jusnaturalistas, resgate do modelo democrático, universalização dos direitos do homem, surgimento do constitucionalismo etc.

Todas estas transformações culminam em dois momentos decisivos para a positivação e consagração dos direitos humanos fundamentais: i) o movimento de independência dos Estados Unidos da América (1776) e a Declaração de direitos do povo da Virgínia, do mesmo ano; ii) a Revolução Francesa (1789) e a Declaração dos Direitos do Homem e do Cidadão.

Foi somente a partir desses dois momentos históricos que se passa a fixar, por escrito e com firme propósito de vinculação pelos governantes e por toda a coletividade, um rol de direitos e de garantias voltados à proteção do homem, na sua individualidade.

Direitos e garantias com pretensão universal, ou seja, aplicáveis a todos os indivíduos, sem distinções ou privilégios, não obstante ainda reinasse a escravidão no mundo (para quem tais direitos ainda não eram aplicáveis). Flagrante, aqui, a influência da 
filosofia jusnaturalista, com seus três expoentes John Locke, Barão de Montesquieu e JeanJacques Rousseau, nos dois movimentos revolucionários e nas respectivas cartas universais de direitos produzidas, como ponto culminante de ambos.

De qualquer sorte, é evidente que tais movimentos importaram em uma ruptura ampliativa do rol de direitos positivados e de seus beneficiários, razão pela qual a doutrina quase unânime consagra esses dois momentos como marcos históricos do surgimento dos direitos humanos fundamentais no formato atualmente concebido.

Sucede que, desde a Antiguidade até o advento da Revolução Francesa, com seu nítido caráter liberal-burguês, a concepção por trás da idéia da necessidade de se garantir direitos aos cidadãos é a da limitação do poder do Estado, para que se impeçam abusos por parte dos governantes.

Ou seja, até aqui falo unicamente de direitos da pessoa humana em face do Estado, em um sentido de proteção do cidadão contra o arbítrio estatal. São os clássicos direitos de defesa, ou direitos a uma abstenção por parte do Estado (um não fazer). Em resumo: direitos de liberdade.

Não é sem razão que ambos os movimentos paradigmáticos de afirmação dos direitos humanos fundamentais implementam, em termos políticos, governos republicanos, inaugurando na prática o conceito de República, com a derrocada dos respectivos regimes monárquicos. Tudo em favor da emergente e já poderosa classe burguesa, detentora dos meios de produção.

Decorrência quase que imediata de tais transformações é o surgimento do constitucionalismo, com seu corolário correspondente, qual seja, o surgimento das primeiras Constituições escritas, todas garantidoras de direitos humanos fundamentais de liberdade (e unicamente estes): francesa (1791 e 1848), espanhola (1812), portuguesa (1822) e belga (1831) ${ }^{1314}$.

\footnotetext{
${ }^{13}$ Para um maior aprofundamento sobre o assunto, estendendo-se desde o surgimento histórico até a fase de consolidação dos direitos humanos fundamentais de liberdade, confira-se, nas já citadas obras, as seguintes páginas: i) MORAES, Alexandre de. Direitos humanos fundamentais, cit., p. 7-11; ii) MARMELSTEIN, George. op. cit., p. 27-36; iii) FIRMINO, Nelson Flávio. op. cit., p. 142-147; iv) FERREIRA FILHO, Manoel Gonçalves. op. cit., p. 29-45; v) SARLET, Ingo Wolfgang. A eficácia dos direitos fundamentais, cit., p. 45-53.

${ }^{14} \mathrm{Um}$ resumo extremamente feliz dessa etapa inaugural da evolução histórica dos direitos humanos fundamentais, até culminar com a fixação de direitos de índole constitucional de liberdade, consta da seguinte passagem da obra de Ingo Wolfgang Sarlet: "Sintetizando o devir histórico dos direitos fundamentais até o seu reconhecimento nas primeiras Constituições escritas, K. Stern, conhecido mestre de Colônia, destaca três etapas: a) uma pré-história, que se estende até o século XVI; b) uma fase
} 
Até tal ponto, conforme já esclarecido anteriormente, houve o surgimento em termos jurídicos de um feixe de direitos voltados unicamente à proteção e garantia da pessoa humana frente ao Estado, ou seja, direitos de liberdade. Direitos esses direcionados primordialmente à proteção da emergente classe burguesa, mola propulsora da nova economia capitalista e sua principal beneficiária.

Sucede que tal revolução econômica deu surgimento não só à dominante classe burguesa, detentora do capital, mas também a uma enorme classe de trabalhadores, que passaram a vender sua força de trabalho para a burguesia capitalista. Estou falando do proletariado, que numericamente passou a ser a maior classe econômica da humanidade.

E, como a ordem capitalista privilegia o dono do capital (acumulação de riqueza), o que se verifica ao longo do século XIX é um movimento de crescente exploração da massa proletária, dentro da lógica da maximização dos lucros e diminuição do preço da mão de obra trabalhadora, movimento acentuado a partir da Revolução Industrial inglesa do início do Século XIX.

Sintomas de tal exploração são a contratação de mulheres e crianças para o trabalho, já que se trata de mão de obra mais barata comparativamente aos trabalhadores adultos do sexo masculino; uma intensificação cada vez maior do número de horas diárias de trabalho (não raras vezes, de 14, 15 horas); a diminuição paulatina do valor pago por hora trabalhada, a proibição de movimentos reivindicatórios etc ${ }^{15}$.

\footnotetext{
intermediária, que corresponde ao período de elaboração da doutrina jusnaturalista e da afirmação dos direitos naturais do homem; c) a fase da constitucionalização, iniciada em 1776, com as sucessivas declarações de direitos dos novos Estados americanos". SARLET, Ingo Wolfgang. A eficácia dos direitos fundamentais, cit., p. 44.

${ }^{15} \mathrm{Um}$ cenário muito interessante da realidade atravessada pela Inglaterra nesse período é dado por Leo Huberman: "Se um marciano tivesse caído naquela ocupada ilha da Inglaterra teria considerado loucos todos os habitantes da Terra. Pois teria visto de um lado a grande massa do povo trabalhando duramente, voltando à noite para os miseráveis e doentios buracos onde moravam, que não serviam nem para porcos; de outro lado, algumas pessoas que nunca sujaram as mãos com o trabalho, mas não obstante faziam as leis que governavam as massas, e viviam como reis, cada qual num palácio individual. Havia, na realidade, duas Inglaterras. Disraeli acentuou isso em sua Sybil: 'Duas nações; entre as quais não há intercâmbio nem simpatia; que ignoram os hábitos, idéias e sentimentos uma da outra, como se habitassem zonas diferentes, e não são governadas pelas mesmas leis.' 'O Senhor fala de ...', disse Egremont, hesitante. 'DOS RICOS E POBRES.' Essa divisão não era nova. Mas com a chegada das máquinas e do sistema fabril, a linha divisória se tornou mais acentuada ainda. Os ricos ficaram mais ricos e os pobres, desligados dos meios de produção, mais pobres. Particularmente ruim era a situação dos artesãos, que ganhavam antes o bastante para uma vida decente e que agora, devido à competição das mercadorias feitas pela máquina, viram-se na miséria". HUBERMAN, Leo. História da riqueza do homem. Tradução de Waltensir Dutra. 8. ed. Rio de Janeiro: ZAHAR, 1972. p. 188-189.
} 
Assim é que, na medida em que a exploração da classe operária cresceu, começaram a surgir movimentos contrários, limitadores de tal exploração, capitaneados pela Igreja Católica e pela própria classe operária (ação e reação).

São movimentos reivindicadores de uma série de direitos voltados à garantia de um mínimo de condições dignas de sobrevivência, ou seja, direitos voltados à proteção de uma classe social específica, o proletariado, contra a exploração burguesa, não mais sob o enfoque da liberdade, e sim da igualdade de condições materiais para uma existência digna.

Trata-se de uma ampliação do rol de direitos humanos fundamentais, passando-se a consagrar direitos prestacionais, de criação de condições de igualdade de oportunidades para todos: direito ao voto, ao trabalho, à previdência e assistência sociais, à saúde, à educação, dentre outros. Tais são os consagrados direitos sociais, que serão melhor analisados no próximo capítulo.

Por ora, basta afirmar que a positivação deste novo feixe de direitos humanos fundamentais se deu com o advento das famosas Constituições do México (1917) e de Weimar (1919), sendo também de enorme relevo histórico a Encíclica Rerum Novarum, editada pelo Papa Leão XIII em $1891^{16}$. O surgimento deste novo feixe de direitos também deu forte impulso à modificação do Estado Liberal para o Estado Social de Direito, cujo modelo mais famoso é o do Welfare State.

Por fim, confluem ao longo do século XX dois movimentos distintos em relação à positivação e garantia de direitos humanos fundamentais: i) um movimento de intensificação da positivação e proteção dos direitos humanos fundamentais de liberdade e de igualdade já consagrados ao longo dos séculos anteriores, tanto no plano internacional, com a edição de uma série de tratados e convenções internacionais, dos quais o mais famoso é a Declaração Universal dos Direitos Humanos, de 1948, quanto no plano interno de cada Estado Soberano, por via da constitucionalização da previsão de tais direitos e garantias, realizada de forma difundida em todos os países do globo; ii) um movimento de reconhecimento e positivação de um novo feixe de direitos humanos fundamentais, agora voltados à proteção do ser humano como integrante e participante da comunidade, que são

\footnotetext{
${ }^{16}$ Para um apanhado dos documentos mais importantes, editados ao longo dos séculos XIX e início do XX, garantidores dos direitos humanos fundamentais de índole social, confira-se: FIRMINO, Nelson Flávio. op. cit., p. 147-148.
} 
chamados de direitos de solidariedade (direito ao meio ambiente, à paz mundial, à autodeterminação dos povos, à qualidade de vida, ao desenvolvimento etc. $)^{17}$.

O Brasil seguiu o movimento mundial, prevendo de forma paulatina e crescente, em cada Constituição editada, feixes de direitos humanos fundamentais: i) direitos humanos fundamentais de liberdade nas Constituições de 1824, 1891, 1934 e 1937, cujo rol foi sendo paulatinamente ampliado em cada edição; ii) direitos humanos fundamentais de liberdade e de igualdade nas Constituições de 1946, 1967 e na Emenda Constitucional n. 01, de 1969; iii) a mais completa de todas, a Constituição atualmente vigente de 1988 previu extenso rol de direitos humanos fundamentais individuais e coletivos, de liberdade, de igualdade e de solidariedade ${ }^{18}$.

\subsection{As três dimensões dos direitos humanos fundamentais (direitos de liberdade, direitos de igualdade e direitos de solidariedade)}

É extremamente interessante notar que, historicamente, houve o surgimento e positivação paulatinos de três categorias diversas de direitos humanos fundamentais, cada qual dotada de características próprias, relacionadas com a própria razão de ser de sua existência em cada momento histórico: i) o primeiro feixe de direitos humanos fundamentais, voltados à proteção da esfera de liberdade do indivíduo em face do Estado, como reação ao regime Absolutista e conformador do Estado de Direito Liberal, tendo como grande beneficiária a classe burguesa e cujas prestações são eminentemente negativas e formais (não fazer pelo Estado; limitação do poder estatal); ii) o segundo feixe de direitos humanos fundamentais, voltados à proteção da esfera de igualdade material de condições dos indivíduos entre si, como reação ao regime jurídico formal burguês e conformador do Estado Social de Direito (Welfare State), tendo como grande beneficiária a classe proletária e cujas prestações são eminentemente positivas (fazer pelo Estado); iii) o terceiro e último feixe de direitos humanos fundamentais, voltados à proteção da esfera da solidariedade entre os indivíduos, com um enfoque não reacionário, mas de ampliação do feixe de direitos sob um enfoque comunitário, universal, a abranger todos os seres

\footnotetext{
${ }^{17}$ Para um maior aprofundamento sobre este novo feixe de direitos humanos fundamentais, de solidariedade, confira-se, nas já citadas obras, as seguintes páginas: i) MARMELSTEIN, George. op. cit., p. 48-50; ii) FIRMINO, Nelson Flávio. op. cit., p. 157-158; iii) FERREIRA FILHO, Manoel Gonçalves. op. cit., p. 7588; iv) SARLET, Ingo Wolfgang. A eficácia dos direitos fundamentais, cit., p. 58-60.

${ }^{18}$ Para um maior aprofundamento do assunto, confira-se: MORAES, Alexandre de. Direitos humanos fundamentais, cit., p. 13-15.
} 
humanos como integrantes da comunidade, a demandar prestações negativas e positivas por parte do Estado (abstenções e obrigações de fazer) ${ }^{19}$.

E a percepção de existência de uma verdadeira equivalência entre tal evolução e o lema da Revolução Francesa é inescapável: Liberté, Egalité et Fraternité. É como se o movimento de expansão dos direitos humanos fundamentais estivesse voltado, desde a Revolução Francesa até o presente momento histórico, à implementação e efetivação do lema revolucionário francês, em uma evolução que demandou quase 250 anos para sua efetivação, e que ainda pende de complementação.

Por isso, considero correta e oportuna esta associação direta, trazida pela doutrina de forma inaugural por Karel Vasak, em virtude de sua objetividade e clareza ${ }^{20}$.

É certo que a expressão "geração" pode gerar alguma confusão em termos do caráter alternativo ou cumulativo de cada grupo de direitos humanos fundamentais positivados como conquistas civilizatórias históricas, em razão do que também reputo mais prudente e preciso o uso da expressão "dimensão"21. Porém, é inegável que a expressão "geração" resume e traduz, de forma clara e singela, a saga da evolução histórica dos direitos humanos fundamentais, devendo ser registrada a felicidade de seu uso por Karel Vasak, inclusive, como atitude sedimentadora da cultura dos direitos humanos fundamentais ao redor do mundo.

Que fique claro desde já que cada feixe de direitos humanos fundamentais mencionados representa um marco de surgimento e positivação de direitos em favor da

\footnotetext{
${ }^{19}$ Não abordarei neste trabalho científico a discussão acerca da existência de novas dimensões de direitos humanos fundamentais, já que tal não é o meu objeto de estudo. Mas, para uma noção acerca do atual estágio da discussão, confiram-se: i) SARLET, Ingo Wolfgang. A eficácia dos direitos fundamentais, cit., p. 60-68; ii) MARMELSTEIN, George. op. cit., p. 50-51; iii) FIRMINO, Nelson Flávio. op. cit., p. 158.

${ }^{20}$ Confira-se, a propósito, o escólio de André de Carvalho Ramos: "A afirmação histórica dos direitos humanos é marcada pela mutação e constante renovação, desde a Antiguidade aos dias de hoje. Por isso, a abordagem tradicional do conteúdo dos direitos humanos é a da chamada 'geração de direitos'. Tal teoria foi lançada pelo jurista francês de origem checa, KAREL VAZAK, que, em Conferência proferida no Instituto Internacional de Direitos Humanos no ano de 1979, classificou os direitos humanos em três gerações, cada uma com características próprias. Assim, a teoria geracional dos direitos humanos divide os direitos protegidos em três (para alguns, quatro) gerações". RAMOS, André de Carvalho. Teoria geral dos direitos humanos na ordem internacional. 2. ed. São Paulo: Saraiva, 2012. p. 71. Interessante é a leitura de sua nota de rodapé “4”, onde aparece, de forma nítida, a correlação explícita levada a efeito por Vasak entre cada geração de direitos humanos fundamentais com cada lema da Revolução Francesa.

${ }^{21}$ Grande entusiasta da utilização da expressão "dimensão" como a mais correta para se referir às diversas modalidades de direitos humanos fundamentais existentes é Ingo Wolfgang Sarlet: “Assim sendo, a teoria dimensional dos direitos fundamentais não aponta, tão-somente, para o caráter cumulativo do processo evolutivo e para a natureza complementar de todos os direitos fundamentais, mas afirma, para além disso, sua unidade e indivisibilidade no contexto do direito constitucional interno e, de modo especial, na esfera do moderno 'Direito Internacional dos Direitos Humanos"'. Confira-se sua obra A eficácia dos direitos fundamentais, cit., p. 55.
} 
pessoa humana, como conquista civilizatória advinda de movimentos reivindicatórios históricos por parte de grupos sociais que transformaram, cada qual, as ordens social, econômica, jurídica, filosófica e política até então reinantes.

Pela ordem de aparição, temos os direitos de liberdade como primeira e inicial dimensão dos direitos humanos fundamentais ( $1^{\text {a }}$ dimensão; séculos XVII e XVIII, com o surgimento do Estado Liberal Burguês, da economia capitalista liberal, da democracia representativa e do jusnaturalismo), seguidos pelos direitos sociais ou de igualdade material ( $2^{\mathrm{a}}$ dimensão; séculos XIX e XX, com o surgimento do Estado Social de Direito, da economia de mercado controlada pelo Estado [Welfare State], da democracia participativa, do materialismo histórico e da escola da teoria crítica), e, por fim, pelos direitos de solidariedade ( $3^{\mathrm{a}}$ dimensão; Séculos XX e XXI, ainda em processo de sedimentação).

Tais direitos se somam ${ }^{22}$, não se excluem, pelo que se verifica um nítido movimento de ampliação dos feixes de direitos humanos fundamentais existentes, ao mesmo tempo em que se amplia o rol de direitos integrantes de cada dimensão, bem como o número de beneficiários de tais direitos ${ }^{23}$.

É de tais constatações que se sacam as principais características dos direitos humanos fundamentais, agora globalmente analisadas: i) historicidade (fruto de longa evolução histórica); ii) indivisibilidade, interdependência e complementaridade (não há divisão ou contradição entre os direitos humanos fundamentais, que são um todo coeso); iii) inalienabilidade; iv) irrenunciabilidade; v) imprescritibilidade; vi) universalidade (os

\footnotetext{
22“"Conquanto esta maneira de ver possa ajudar a empreender os diferentes momentos históricos de aparecimento dos direitos, o termo geração, geração de direitos, afigura-se enganador por sugerir uma sucessão de categorias de direitos, umas substituindo-se às outras - quando, pelo contrário, o que se verifica em Estado social de direito é um enriquecimento crescente em resposta às novas exigências das pessoas e das sociedades". MIRANDA, Jorge. op. cit., v. 4, p. 24.

${ }^{23}$ Embora não seja objeto propriamente dito deste estudo, até porque reconheço válido e extremamente útil o critério da classificação dos direitos humanos fundamentais em três dimensões, vale a pena a leitura da obra de Jairo Schäfer intitulada "Classificação dos direitos fundamentais: do sistema geracional ao sistema unitário" (2. ed. Porto Alegre: Livr. do Advogado, 2013), onde se propõe um estudo dos direitos humanos fundamentais voltado à configuração de um sistema jurídico unitário. Apenas lembro que adotar o sistema classificatório dimensional dos direitos humanos fundamentais não importa negar a necessidade de criação de um sistema jurídico unitário, mas apenas demonstrar a existência de feixes próprios de direitos, aglutinados em razão de suas peculiaridades próprias. Também entendo que os direitos humanos fundamentais possuem um regime jurídico único comum, que fica nítido nas características de universalidade, interdependência e complementaridade entre eles, porém, sem perder de vista a existência de feixes específicos de direitos, que possuem outras características peculiares justificadoras de tal classificação.
} 
beneficiários de tais direitos são todos os seres humanos); vii) efetividade (caráter cogente de tais direitos, garantidos pelos ordenamentos jurídicos estatais e internacional ${ }^{24}$.

\subsection{Fundamentos filosóficos}

Os fundamentos teórico-filosóficos utilizados para o surgimento e sedimentação dos direitos humanos fundamentais, no mais das vezes apontam na direção de uma evolução em torno de quatro ideias principais: sua origem divina (São Tomás de Aquino), o jusnaturalismo (Locke, Montesquieu, Rousseau), o positivismo jurídico (Kelsen) e a sua origem moral (Perelman, Habermas, Dworking). Isso sem falar nos negacionistas, que negam a existência de direitos humanos fundamentais de caráter universal, ao argumento de se tratar de algo impossível dentro da pluralidade cultural de nossa humanidade; não obstante a grande maioria defenda a existência de direitos fundamentais da pessoa humana, apenas reconhecendo que o trajeto rumo à sua positivação passa por constantes retrocessos e reiteradas lutas por confirmação (Norberto Bobbio) ${ }^{25}$.

Trata-se de teorias que buscam explicar a razão do surgimento e sedimentação dos direitos humanos fundamentais, disputando entre si o papel de melhor fundamento filosófico para tanto.

Outra disputa teórico-filosófica de enorme relevo dentro do campo dos direitos humanos fundamentais é a dicotomia entre o caráter universalista ou relativista de tais direitos, resumida na seguinte indagação: os direitos humanos fundamentais são iguais para todos os povos e culturas, ou diferem de acordo com critérios espaço-temporais?

As quatro primeiras teorias apontadas (origem divina, jusnaturalista, positivista e origem moral), assim como as demais tendentes a procurar justificar a existência dos direitos humanos fundamentais, são universalistas, pois consideram que existe um feixe de direitos superiores (=fundamentais) voltados à proteção de todos os seres humanos, que jamais poderão ser suprimidos pelos governos, tampouco modificados.

\footnotetext{
${ }^{24}$ Para um aprofundamento no estudo das principais características dos direitos humanos fundamentais, confira-se: i) MORAES, Alexandre de. Direitos humanos fundamentais, cit., p. 22; ii) MARMELSTEIN, George. op. cit., p. 53-57; iii) FIRMINO, Nelson Flávio. op. cit., p. 149; iv) SILVA, José Afonso da. op. cit., p. 181; v) SAMPAIO, José Adércio Leite. Teoria da Constituição e dos direitos fundamentais. Belo Horizonte: Del Rey, 2013. p. 549-560.

${ }^{25}$ Acerca dos fundamentos filosóficos comumente utilizados para o surgimento e positivação dos direitos humanos fundamentais, confira-se: i) MORAES, Alexandre de. Direitos humanos fundamentais, cit., p. $15-$ 16; ii) RAMOS, André de Carvalho. op. cit., p. 40-49; iii) FIRMINO, Nelson Flávio. op. cit., p. 215; iv) CANOTILHO, José Joaquim Gomes. Direito constitucional e teoria da Constituição. 7. ed. 11. reimp. Coimbra: Almedina, 2003. p. 1395-1402.
} 
Já os relativistas, de que são exemplo os negacionistas, não acreditam na existência de direitos humanos fundamentais de índole universal, mas sim que tais direitos variam de acordo com o tempo e o espaço (=local) analisados ${ }^{26}$.

Não obstante, basta verificar as características comumente atreladas aos direitos humanos fundamentais, bem como seu próprio conceito e evolução histórica, para se constatar que o movimento levado a cabo ao longo dos vários séculos de evolução sempre foi no sentido de sua universalização ${ }^{27}$, seja em termos de beneficiários (todos os seres humanos), seja em termos de ampliação de feixes de direitos (diversas dimensões) e de direitos integrantes de cada feixe, bem como no sentido de criação de um sistema internacional e mundial de proteção a tais direitos (sistema universal de proteção).

Tal caráter é flagrante ao se considerar o surgimento do sistema internacional de proteção dos direitos humanos fundamentais, que tomou corpo logo após a descoberta das atrocidades cometidas durante a Segunda Guerra Mundial pela Alemanha Nazista contra os judeus, culminando no esforço mundial de elaboração da Declaração Universal dos Direitos Humanos, de 1948 - ou seja, somente três anos após o final da guerra. Indiscutível a presença dos ideais kantianos universais ao longo de seu corpo ${ }^{28}$.

Neste ponto, trago uma colaboração ao estudo das origens, do desenvolvimento e da sedimentação dos direitos humanos fundamentais.

Uma vez constatado que os direitos humanos fundamentais são fruto de um longo processo histórico de surgimento, sedimentação, positivação e ampliação, sempre tendentes à universalização, então, muito produtivo é o enfoque de sua análise dento da chamada "Teoria Crítica".

O que vem a ser a "Teoria Crítica"?

\footnotetext{
${ }^{26}$ Para aprofundamento, indico artigos de Leonardo Massud, intitulado Universalismo e relativismo cultural, p. 59-73, e de Melina Girardi Fachin, intitulado Universalismo versus relativismo: superação do debate maniqueísta acerca dos fundamentos dos direitos humanos, p. 75-93; in PIOVESAN, Flávia; IKAWA, Daniela (Coords.). Direitos humanos: fundamento, proteção e implementação; perspectivas e desafios contemporâneos. Curitiba: Juruá, 2008. v. 2.

${ }^{27}$ Utilizo a expressão "universalização" de forma rigorosa e proposital, para demonstrar que o movimento dos direitos humanos fundamentais busca a universalidade. Não são direitos universais, mas menos ainda relativos, e sua evolução inexorável é no sentido da universalização.

${ }^{28}$ Vale a pena conferir, a propósito, artigo da lavra de Carolina de Mattos Ricardo, intitulado Reflexões kantianas na construção histórica dos direitos humanos. In: PIOVESAN, Flávia; IKAWA, Daniela (Coords.). Direitos humanos: fundamento, proteção e implementação; perspectivas e desafios contemporâneos. Curitiba: Juruá, 2008. v. 2, p. 31-41.
} 
Remontando historicamente aos escritos de Karl Marx, e tendo sua origem declarada em estudos de Horkheimer, da década de $1930^{29}$, a Teoria Crítica surgiu como um modelo de estudo da sociedade e de suas condições, voltado não apenas a descrever os seus mecanismos de funcionamento em certa época e local, mas a identificar as falhas e inconsistências presentes na realidade social, criticando-as, e a apontar, outrossim, caminhos para o seu aprimoramento e desenvolvimento. Trata-se de uma análise real e crítica da realidade social de certo tempo e local.

Daí vem sua enorme importância e utilidade para o estudo do surgimento e da evolução dos direitos humanos fundamentais, exatamente em razão de seu caráter histórico, de estudo das lutas sociais pelo reconhecimento de direitos em favor de certas categorias de pessoas, em um caminho de crítica da realidade social de cada época, apontando deficiências e possibilidades de melhorias; o que inegavelmente ocorreu, durante a evolução da humanidade, por meio do movimento de constante ampliação dos direitos humanos fundamentais como fruto de lutas pelo reconhecimento da pessoa humana como sujeito de direitos.

Nesse exato sentido, observe que, conforme afirmado anteriormente, os primeiros direitos humanos fundamentais foram positivados já em razão de lutas travadas entre o Rei inglês, de um lado, e a nobreza e o clero, de outro, culminando com o surgimento da Magna Charta Libertatum, em 1215.

De 1215 até a Revolução Francesa (1789), o movimento de surgimento, positivação e ampliação dos direitos humanos fundamentais limitou-se ao reconhecimento de direitos em favor, notadamente, de uma classe social em específico: a burguesia.

É evidente que outras categorias de pessoas também tiveram reconhecidos tais direitos, até mesmo porque, na época da Revolução Francesa, surgiu a ideia da igualdade formal, materializada na prevalência e aplicação uniforme das leis sobre e para todos, mecanismo inegável de universalização do reconhecimento de direitos à pessoa humana.

\footnotetext{
${ }^{29}$ Por se tratar de um modelo de estudo inaugurado por Max Horkheimer, juntamente com Felix Weil e Friedrich Pollock junto à Universidade de Frankfurt, mediante a criação do "Instituto de Pesquisa Social", a vertente intelectual da Teoria Crítica ficou amplamente conhecida como "Escola de Frankfurt", não obstante não se limite a tal círculo intelectual. Para um maior aprofundamento sobre o assunto, notadamente em termos de melhor caracterização do que venha a ser a Teoria Crítica, e sua não delimitação unicamente à chamada "Escola de Frankfurt", confira-se a excelente apresentação escrita por Marcos Nobre à Obra de Axel Honneth intitulada Luta por reconhecimento: a gramática moral dos conflitos sociais. Tradução Luiz Repa. 1. ed. São Paulo: Ed. 34, 2003.
} 
Porém, é inegável que foi a emergente classe burguesa quem mais se beneficiou do movimento dos direitos humanos fundamentais nesse período, e não é sem razão que a primeira dimensão de direitos humanos fundamentais teve como objetivo e objeto principais a positivação e garantia de "liberdades públicas" (também chamadas de direitos de defesa ou negativos, impositivos de um não fazer por parte do Estado), ou seja, direitos limitadores do poder estatal - leia-se, limitação do poder real da época, com a derrocada do Absolutismo, abrindo espaço para a ascensão burguesa.

Sucede que a evolução da sociedade não segue um caminho linear, de evolução em uma única direção. Assim é que, nos dois séculos seguintes (XIX e XX), e fruto uma vez mais de constantes lutas pelo reconhecimento de direitos, houve a positivação e garantia dos chamados "Direitos Sociais", voltados à proteção daqueles materialmente necessitados, notadamente a classe operária, altamente explorada pela burguesia, dando origem à segunda dimensão de direitos humanos fundamentais, com a imposição de deveres prestacionais por parte do Estado, direcionados à garantia de igualdade material para todos.

Por fim, e já na metade do século XX, há o surgimento da terceira dimensão de direitos humanos fundamentais, que são os direitos de solidariedade, em um claro movimento de universalização da proteção da pessoa humana, agora vista sob um enfoque não exclusivamente individual, mas coletivo, ou seja, a pessoa humana em suas relações sociais. São direitos positivados em favor de grupos e de coletividades inteiras, impositivos de deveres não só perante o Estado, mas também perante cada ser humano, de respeito aos direitos do próximo e com o objetivo de permitir o máximo gozo possível por todos e por cada um.

Fica claro, assim, o triplo movimento histórico na dinâmica de surgimento e positivação dos direitos humanos fundamentais: i) um movimento inicial de surgimento $e$ ampliação no número de direitos assegurados à pessoa humana, voltados à sua proteção; ii) um movimento um pouco mais tardio de ampliação do número de pessoas beneficiadas por tais direitos, de universalização do conceito de pessoa humana como sujeito de direitos; iii) um movimento relativamente recente de ampliação de enfoque dos direitos humanos fundamentais, passando de um enfoque exclusivamente individual para uma 
visão de grupos humanos e, no presente, com uma visão coletiva global, do ser humano como participante da sociedade ${ }^{30}$.

A vertente da Teoria Crítica que melhor explora tal dinâmica, qual seja, do surgimento, sedimentação, positivação e ampliação dos direitos humanos fundamentais como um processo de constante luta pelo reconhecimento da pessoa humana como sujeito de direitos, é a Escola de Frankfurt, notadamente por meio de dois teóricos, aqui utilizados: Axel Honneth e Hans Joas.

Honneth $^{31}$ parte do modelo hegeliano de luta pela autoconservação do indivíduo, com enfoque nas relações intersubjetivas de conflito, desenvolvendo um modelo de análise social também fulcrado nas relações intersubjetivas de conflitos (lutas) pelo reconhecimento, mas agora fincado em um tripé: a existência de três padrões de reconhecimento intersubjetivo, a saber, o amor, o direito e a solidariedade.

O amor corresponde ao padrão mais íntimo de reconhecimento da pessoa humana (ela com ela mesma), seguido pelo direito (indivíduo com indivíduo) e culminando com a solidariedade (indivíduo visto pela coletividade).

Tais padrões de reconhecimento possuem, por sua vez, as correspondentes patologias, que levam exatamente aos processos intersubjetivos conflituosos em decorrência do desrespeito à pessoa humana: respectivamente, a violação, a privação de direitos e a degradação.

Fica claro que o presente trabalho aborda o padrão de reconhecimento do direito dentro da lógica dos conflitos sociais, por se tratar de uma obra jurídica.

Observe como a dinâmica de análise de Honneth acerca das relações sociais em muito se aproxima do movimento de surgimento, sedimentação, positivação e ampliação dos direitos humanos fundamentais, exatamente como um processo de luta constante de

\footnotetext{
${ }^{30}$ Norberto Bobbio também traz, de forma clara e objetiva, esse processo de ampliação dos direitos humanos fundamentais em três frentes, ao afirmar: "Essa multiplicação (ia dizendo 'proliferação') ocorreu de três modos: a) porque aumentou a quantidade de bens considerados merecedores de tutela; b) porque foi estendida a titularidade de alguns direitos típicos a sujeitos diversos do homem; c) porque o próprio homem não é mais considerado como ente genérico, ou homem em abstrato, mas é visto na especificidade ou na concreticidade de suas diversas maneiras de ser em sociedade, como criança, velho, doente, etc. Em substância: mais bens, mais sujeitos, mais status do indivíduo. É supérfluo notar que, entre esses três processos, existem relações de interdependência: o reconhecimento de novos direitos de (onde 'de' significa sujeito) implica quase sempre o aumento de direitos a (onde 'a' indica o objeto)". BOBBIO, Norberto. A era dos direitos. Tradução Carlos Nelson Coutinho. 18. tir. Rio de Janeiro: Elsevier, 2004. p. 63.

${ }^{31}$ Aconselho a leitura da segunda parte da obra de Axel Honneth Luta por reconhecimento: a gramática moral dos conflitos sociais, cit., p. 117 a 224, para melhor compreensão de sua tese.
} 


\title{
grupos e categorias sociais pelo reconhecimento como sujeitos de direitos dentro da ordem jurídica vigente.
}

Dentro desta ótica, a categoria jurídica dos direitos humanos fundamentais representa a etapa final do processo dentro do padrão de reconhecimento do direito, tal qual elaborado por Honneth, quando são positivados os direitos exigidos pelos diversos grupos sociais.

O resultado deste processo constante de lutas pelo reconhecimento levou, leva e levará inexoravelmente a uma dinâmica de ampliação e universalização constantes dos direitos humanos fundamentais, inclusive e notadamente em termos de positivação pelos diversos ordenamentos jurídicos estatais, além do campo internacional.

Um resumo extremamente feliz desta junção entre movimentos revolucionários pelo reconhecimento da pessoa humana como sujeito de direitos e o surgimento, sedimentação, positivação e ampliação dos direitos humanos fundamentais é dado da seguinte forma por Axel Honneth:

\begin{abstract}
A hipótese evolutiva assim traçada, porém, só pode se tornar a pedra angular de uma teoria da sociedade na medida em que ela é remetida de maneira sistemática a processos no interior da práxis da vida social: são as lutas moralmente motivadas de grupos sociais, sua tentativa coletiva de estabelecer institucional e culturalmente formas ampliadas de reconhecimento recíproco, aquilo por meio do qual vem a se realizar a transformação normativamente gerida das sociedades $^{32}$.
\end{abstract}

Assim é que, não obstante não concorde com o caráter relativista dos direitos humanos fundamentais, tampouco com seu surgimento apenas no início da Era Moderna, como defende Norberto Bobbio $^{33}$ - isso pelas razões já exaustivamente expostas anteriormente -, estou de pleno acordo com a inserção de seu surgimento e desenvolvimento dentro da lógica da luta pelo reconhecimento da pessoa humana como

\footnotetext{
${ }^{32}$ HONNETH, Axel. op. cit., p. 156. Também Norberto Bobbio defende o surgimento e evolução dos direitos humanos fundamentais como um processo inserido dentro da lógica da luta por reconhecimento, in BOBBIO, Norberto. op. cit., p. 5. Confira-se, ademais, HABERMAS, Jürgen. Um ensaio sobre a Constituição da Europa. Tradução Marian Toldy e Teresa Toldy. 1. ed. Lisboa: Edições 70, 2012. p. 51.

${ }^{33}$ Bobbio deixa muito claro seu pensamento no sentido de que os direitos humanos fundamentais representariam conquistas relativas, variáveis de acordo com o tempo, local e cultura pesquisados, já nas primeiras páginas de sua obra "A era dos direitos", valendo conferir, para aprofundamento, o capítulo referente à "introdução", p. 01-12. Também é interessante notar como, partindo de uma mesma constatação - a de que os direitos humanos fundamentais são fruto de um processo histórico de lutas por reconhecimento da pessoa humana como sujeito de direitos - Bobbio, de um lado, e Honneth e Joas, de outro, chegam a conclusões diversas: o primeiro ao caráter relativista e, de certa forma, "precário", dos direitos humanos fundamentais; os segundos, ao caráter universalizante e cristalizador dos mesmos direitos. Creio tenha ficado clara minha posição em favor da segunda vertente.
} 
sujeito de direitos, e que elevou o ser humano à categoria de elemento fundamental $e$ central dos sistemas filosófico, político, social, moral e jurídico atualmente vigentes.

No concernente à evolução histórica deste processo, a Teoria Crítica a entende como um movimento constante e necessário de ampliação de direitos voltados ao reconhecimento de certos grupos sociais como membros de igual valor dentro da comunidade.

Ou seja, a evolução histórica dos direitos humanos fundamentais tem por fio condutor também a luta pelo reconhecimento, levada a cabo, em um primeiro momento, pela burguesia ascendente, com o surgimento dos direitos de liberdade (liberdades públicas); em seguida, pelos movimentos sociais e dos trabalhadores, dando origem aos direitos de igualdade (direitos sociais e de participação democrática); mais recentemente, por grupos ambientalistas e novos movimentos sociais, dando origem aos direitos de solidariedade ${ }^{34}$.

Tal processo de paulatino e crescente reconhecimento de direitos humanos fundamentais em favor da pessoa humana possui inegável caráter universalizante, isto é, tende a abarcar toda a humanidade, em um movimento de contínua ampliação, seja em termos de beneficiários, seja no número de direitos assegurados ${ }^{35}$.

O conceito jurídico chave deste processo de reconhecimento da pessoa humana dentro do sistema jurídico é o de "sujeito de direitos", como elemento fundamental dos ordenamentos jurídicos modernos, cujo surgimento e evolução possuem uma dinâmica e história próprias, altamente influenciada por dois movimentos principais: i) o cristianismo,

\footnotetext{
${ }^{34}$ Tal movimento expansionista é trazido de forma cristalina na seguinte passagem de Honneth, ao retomar as ideias de Thomas Marshall: "Marshall dá a essa tripartição uma inflexão histórica, cuja versão mais tosca reza que a constituição dos direitos liberais de liberdade deu-se no século XVIII, o estabelecimento dos direitos políticos de participação, no século XIX, e finalmente a criação de direitos sociais de bem-estar, no XX; no entanto, em sua sugestiva periodização, mais refinada na sequência, é importante para os nossos fins somente a demonstração de que a imposição de cada nova classe de direitos fundamentais foi sempre forçada historicamente com argumentos referidos de maneira implícita à exigência de ser membro com igual valor da coletividade política”. HONNETH, Axel. op. cit., p. 191.

${ }^{35}$ Confira-se, a propósito, a seguinte passagem de Honneth: “(...) o princípio de igualdade embutido no direito moderno teve por consequência que o status de uma pessoa de direito não foi ampliado apenas no aspecto objetivo, sendo dotado cumulativamente de novas atribuições, mas pôde também ser estendido no aspecto social, sendo transmitido a um número sempre crescente de membros da sociedade. (...) no segundo caso, ao contrário, a relação jurídica é universalizada no sentido de que são adjudicados a um círculo crescente de grupos, até então excluídos ou desaparecidos, os mesmos direitos que a todos os demais membros da sociedade. Uma vez que as relações jurídicas modernas contêm estruturalmente essas duas possibilidades evolutivas, tanto Hegel quanto Mead estão convencidos de que há um prosseguimento da 'luta por reconhecimento' no interior da esfera jurídica; portanto, os confrontos práticos, que se seguem por conta da experiência do reconhecimento denegado ou do desrespeito, representam conflitos em torno da ampliação tanto do conteúdo material como do alcance social do status de uma pessoa de direito". HONNETH, Axel. op. cit., p. 193-194.
} 
com seu dogma do ser humano constituído à imagem e semelhança de Deus (imago Dei); ii) o racionalismo individualista, que eleva o ser humano à posição de centro do universo (antropocentrismo), como condutor das transformações sociais e, por decorrência, como peça mestra dos sistemas jurídicos modernos, construídos ao redor do pilar do elemento estrutural "sujeito de direitos".

Assim é que, em termos de evolução histórica, a ideia do ser humano visto como imagem e semelhança de Deus, pilar do ideal cristão, vai sendo deslocada de sua tradição religiosa, passando por um processo de secularização que, com o advento do racionalismo, eleva o ser humano à categoria de centro do universo, como seu elemento integrante mais importante, responsável pelas grandes transformações ocorridas no mundo.

Inicia-se, assim, um movimento de valorização do ser humano como fim em si mesmo, o que no universo jurídico o coloca como elemento central do sistema, qual seja, como "sujeito" dos direitos, e não mero objeto.

Trata-se de um processo extremamente longo, que se inicia com o advento do cristianismo, primeira religião defensora da origem divina do homem, segundo ela criado à luz e semelhança de Deus, dotado da dualidade corpo/alma e que, como tal, deve ser respeitado e tratado como semelhante por todos e cada um; essa concepção desloca-se do campo religioso para o campo científico, com o racionalismo e a ideia de que o homem é o centro do universo; o processo culmina com as várias manifestações de reconhecimento de categorias até então excluídas do conceito de "pessoa humana"36, em um claro movimento universalizante de proteção do ser humano como sujeito de direitos, muito bem captado por Hans Joas ${ }^{37}$.

Em reforço às ideias de Joas, de conjunção entre o ideal cristão de igualdade e o racionalismo moderno individualista como propulsores do processo de sacralização da pessoa como sujeito de direitos humanos fundamentais, confira-se Bobbio, ao afirmar: "No

\footnotetext{
${ }^{36}$ Inegavelmente o movimento revolucionário mais expressivo de universalização do reconhecimento da pessoa humana como sujeito de direitos foi o movimento antiescravista, que será oportunamente abordado, mesmo que de forma pontual.

37، A ideia-chave deste livro é, portanto, que a história dos direitos humanos constitui uma história de sacralização desse tipo, mais precisamente uma história da sacralização da pessoa. (...) Com efeito, se os direitos humanos de fato recorrem a tradições como a cristã, mas pressionam essas tradições na direção de uma nova articulação, então valores como o da dignidade humana são universais e direitos como os direitos humanos não estão 'trancafiados' numa determinada tradição. Eles também estarão acessíveis a partir de outras tradições e sob novas condições, na medida em que lograrem uma reinterpretação criativa similar desses direitos e valores, como a que a tradição cristã sem dúvida conseguiu amplamente. Em conseqüência disso, tais tradições religiosas ou culturais também podem encontrar novos aspectos em comum, sem romper consigo mesmas". JOAS, Hans. A sacralidade da pessoa: nova genealogia dos direitos humanos. Tradução Nélio Schneider. São Paulo: Unesp, 2012. p. 19 e 22.
} 
final desse caminho, parece agora ter ocorrido, para além dos insensatos e estéreis facciosismos, a reconciliação do pensamento cristão com uma das mais altas expressões do pensamento racionalista e laico" 38 .

Em termos históricos, de enorme relevo se revelou o movimento antiescravista, levado a efeito ao longo dos séculos XVIII e XIX, único que conseguiu, finalmente, libertar uma categoria imensa de seres humanos - os escravos - de sua mera condição de objeto, integrando-a à nobre categoria de sujeito de direitos (de pessoa humana como sujeito de relações jurídicas, e não mero objeto, apropriável). Trata-se de movimento decisivo para a efetiva universalização da pessoa humana como sujeito de direitos ${ }^{39}$.

Interessante verificar, outrossim, que o próprio movimento de surgimento e consolidação do conceito de "pessoa", como ser humano visto em sua individualidade e colocado como o centro dos diversos sistemas sociais, passa pelos mesmos estágios e sofre as mesmas influências aqui já demonstradas no tocante ao movimento em prol dos direitos humanos fundamentais (plano jurídico), o que pode ser percebido pelo resumo evolutivo apresentado por Marcel Mauss:

De uma simples mascarada à máscara; de um personagem a uma pessoa, a um nome, a um indivíduo; deste a um ser com valor metafísico e moral; de uma consciência moral a um ser sagrado; deste a uma forma fundamental do pensamento e da ação; foi assim que o percurso se realizou ${ }^{40}$.

Fica claro, assim, que todos esses movimentos evolutivos se encontram umbilicalmente imbricados - a pessoa como sujeito de direitos, sua sacralização, os direitos humanos fundamentais -, como faces de uma mesma realidade complexa, moldada ao longo do tempo em razão das constantes e inúmeras lutas por reconhecimento travadas pelos diversos grupos sociais, em favor dos quais o direito surge como locus formal e importante de reconhecimento de direitos.

\footnotetext{
${ }^{38}$ BOBBIO, Norberto. op. cit., p. 119.

${ }^{39}$ Confira-se o escólio de Hans Joas: "Essas asserções esquemáticas e abstratas serão concretizadas agora num exemplo central para o tema deste livro, a saber, no que certamente constituiu o movimento mais importante pelos direitos humanos do século XIX: o abolicionismo, o movimento em favor da eliminação da escravidão". JOAS, Hans. op. cit., p. 131.

${ }^{40}$ MAUSS, Marcel. Sociologia e antropologia. Tradução de Paulo Neves. São Paulo: Cosac \& Naify, 2003. p. 397.
} 


\subsection{Considerações finais}

Procurei demonstrar com este capítulo inicial o longo e conflituoso processo histórico de surgimento, cristalização, positivação e ampliação dos direitos humanos fundamentais, como fruto de processos de luta pelo reconhecimento de grupos humanos como sujeitos de direito.

Foi em razão de tal dinâmica de conflitos pelo reconhecimento que os direitos humanos fundamentais foram surgindo de forma paulatina, em três grandes movimentos, atrelados cada qual a um grupo notadamente beneficiário dos movimentos reivindicatórios: a burguesia (direitos de liberdade, séculos XVII e XVIII), o proletariado (direitos sociais, séculos XIX e primeira metade do XX) e a coletividade (segunda metade do século XX).

Também tal dinâmica possui um caráter inegavelmente ampliador dos beneficiários (pessoas) e do número de direitos garantidos em cada grupo (dimensão), além de ampliador do enfoque a ser dado aos beneficiários (caráter individual e, posteriormente, coletivo).

Outra característica marcante desse processo de lutas pelo reconhecimento foi a passagem do reconhecimento de tais direitos das esferas filosófica, política, econômica e social para a esfera do direito, com a positivação paulatina de cada dimensão de direitos humanos fundamentais nas ordens jurídicas dos diversos Estados Ocidentais; o que gerou, inclusive, o movimento de constitucionalização dos sistemas jurídicos internos, com a criação do Estado Liberal de Direito no século XIX, acompanhado dos direitos humanos fundamentais de liberdade, passando pelo Estado Social de Direito do século XX e a inserção dos correspondentes direitos sociais; e culminando com o atual Estado Democrático e Social de Direito, da segunda metade do século XX, com a inserção da categoria de direitos de solidariedade (meio ambiente, democracia participativa, autodeterminação, dentre outros direitos, chamados de "terceira dimensão").

Interessante notar que tal processo histórico, longo e contínuo, tem levado os direitos humanos fundamentais a um processo inegável de universalização, qual seja, de ampliação gradativa e constante do número de direitos garantidos e positivados, mas também de pessoas beneficiadas, além de um aprofundamento contínuo dos mecanismos de garantia e de efetividade de tais direitos nas ordens jurídicas.

Perfilho-me, assim, a Honneth e Joas, quando afirmam que os direitos humanos fundamentais tendem à universalização, a uma ampliação cada vez maior em termos de 
reconhecimento, fruto de constantes lutas sociais, do ser humano alçado a elemento central dos modernos sistemas jurídicos (sujeito de direitos), a ponto de sua "sacralização"; mas sem que eu perca de vista as preocupações práticas que levaram Bobbio a negar tal caráter, em razão dos retrocessos fatalmente verificados ao longo da história humana, cheia de avanços, retrocessos e saltos evolutivos.

Em arremate, parece-me claro que o resultado de tal processo fortaleceu e muito, em termos justificativos, as próprias características basilares dos direitos humanos fundamentais, agora muito bem embasadas em uma teoria consistente e de grande rigor racional: i) historicidade (fruto de longa evolução histórica); ii) indivisibilidade, interdependência e complementaridade (não há divisão ou contradição entre os direitos humanos fundamentais, que são um todo coeso); iii) inalienabilidade; iv) irrenunciabilidade; v) imprescritibilidade; vi) universalidade (os beneficiários de tais direitos são todos os seres humanos); vii) efetividade (caráter cogente de tais direitos, garantidos pelos Ordenamentos Jurídicos).

De todo o exposto resulta o relevante papel do direito como locus de reconhecimento da pessoa humana como sujeito de direitos, também em um claro e constante movimento de ampliação da positivação de tais direitos, bem como de sua importância, evidenciada na constatação geral de que os direitos humanos fundamentais contam hoje com diversos sistemas internacionais de proteção, em um movimento de especialização (capítulo 2), além de estarem previstos, invariavelmente, no bojo das Constituições dos Estados, e frequentemente protegidos pela imutabilidade das chamadas “cláusulas pétreas”, o que será tratado no capítulo 3 . 


\section{DOS DIREITOS SOCIAIS: CONCEITO, ABRANGÊNCIA (PLANOS INTERNACIONAL E INTERNO) E EFICÁCIA}

\subsection{Evolução histórica}

Passo, a partir de agora, em um processo nítido de aproximação do meu objeto de estudo, a focar a análise sobre a segunda dimensão de direitos humanos fundamentais, consagradamente intitulada "Direitos Sociais".

Já foi verificado, no primeiro capítulo, que tal feixe de direitos teve seu surgimento e evolução históricos notadamente entre os séculos XIX e primeira metade do século XX, como fruto da Revolução Industrial ocorrida na Inglaterra e o surgimento de uma nova classe social, o proletariado, paulatina e crescentemente explorada pela dominante classe burguesa, beneficiária dos movimentos revolucionários consagradores da primeira dimensão dos direitos humanos fundamentais - os direitos de liberdade e de igualdade formal (=liberdades públicas).

Dentro da lógica já explorada no primeiro capítulo, de surgimento de feixes de direitos humanos fundamentais como fruto de movimentos sociais de massa reivindicadores do reconhecimento jurídico como sujeitos de direitos, é fácil localizar o feixe de direitos sociais como fruto de inúmeros e crescentes movimentos de reivindicação da classe operária em prol da melhoria das condições de trabalho, salariais, de saúde e segurança no trabalho, de amparo nas situações de vulnerabilidade social decorrentes do desemprego e da própria limitação física do ser humano no desempenho laboral ${ }^{41}$.

Trata-se de uma reação à excessiva exploração pela classe burguesa, até então a maior beneficiária pela positivação do primeiro feixe de direitos humanos fundamentais.

É correto, assim, afirmar que o surgimento, a sedimentação, positivação e evolução dos direitos humanos fundamentais sociais tiveram como grande grupo beneficiado a classe operária ${ }^{42}$, em um nítido movimento de ampliação quantitativa e qualitativa dos direitos humanos fundamentais.

\footnotetext{
${ }^{41}$ Para um quadro muito bem elaborado da situação de penúria enfrentada pela classe operária na Inglaterra do pós Revolução Industrial, confira-se a obra de Leo Huberman, História da riqueza do homem, cit., capítulo XVI, p. 187-206.

42“"Contrapostos aos direitos de liberdade são, nesse século e no século XX reivindicados (sobretudo, por movimentos de trabalhadores) e sucessivamente obtidos, direitos económicos, sociais e culturais - direitos económicos para garantia da dignidade do trabalho, direitos sociais como segurança na necessidade e
} 
A doutrina é praticamente unânime em fixar sete grandes acontecimentos históricos de enorme relevo no movimento de surgimento, cristalização, positivação e expansão dos direitos sociais como o segundo feixe de direitos humanos fundamentais, a saber: i) a Constituição francesa revolucionária de 1848, a qual, por ter sido fruto de revolução que contou com grande participação das classes menos favorecidas, notadamente a classe operária e os desvalidos, acabou por reconhecer uma incipiente proteção social às classes mais necessitadas, contrariamente aos interesses da burguesia; ii) quase que concomitantemente, o surgimento do Manifesto Comunista, de Karl Marx e Frederich Engels, fundado na obra $O$ Capital, de Marx, que sacudiu a intelectualidade da época com um novo método de abordagem científica da realidade social ("materialismo histórico", precursor da escola da "Teoria Crítica"), pelo qual se deixa de apenas descrever a realidade social, política e econômica de dado período e local, passando para uma abordagem crítica dos sistemas vigentes, na busca de soluções e aprimoramentos, e que representou feroz crítica ao sistema econômico capitalista liberal da época, indicando a luta de classes como o problema e caminho para a evolução da sociedade; iii) o movimento social da Igreja católica ("doutrina social da igreja”), que teve seu auge com a famosa Encíclica Rerum Novarum, editada pelo Papa Leão XIII em 1891, voltada para a análise e crítica da exploração da miséria humana que havia tomado conta do mundo da época; iv) A Constituição mexicana de 1917, como a primeira Carta Constitucional formal consagradora de direitos sociais específicos; v) no mesmo ano, a Revolução Russa de 1917, que acabou com o regime czarista, altamente liberal-burguês, iniciando um processo de instauração de um regime comunista, liderado por Lênin, seguidor das idéias de Marx; vi) logo em seguida, a Constituição de Weimar, de 1919, como a primeira Constituição de um país europeu positivadora de direitos sociais; vii) no mesmo ano, o surgimento da Organização Internacional do Trabalho (OIT), como primeiro organismo internacional voltado à proteção dos trabalhadores ao redor do mundo ${ }^{43}$.

Percebe-se claramente destes eventos históricos a dinâmica das lutas sociais pelo reconhecimento de direitos, operadas pela classe operária, com o apoio de intelectuais e da

direitos culturais como exigência de acesso à educação e à cultura e em último termo de transformação da condição operária". MIRANDA, Jorge. op. cit., v. 4, p. 22-23. Confira-se, outrossim: MORAES, Alexandre de. Direito constitucional. 23. ed. São Paulo: Atlas, 2008. p. 193.

${ }^{43}$ Excelente panorama em termos de surgimento e positivação dos direitos humanos fundamentais sociais ao longo da história é dado por Sérgio Pinto Martins em sua Direitos fundamentais trabalhistas. São Paulo: Atlas, 2008. p. 5-32. Confira-se, outrossim: CESARINO JUNIOR, Antônio Ferreira. Direito social. São Paulo: LTr, 1980. p. 73-80. 
Igreja Católica, que culminam com a positivação de direitos voltados à proteção de tal categoria $^{44} 45$.

\subsection{Conceito, características principais e espécies}

\subsubsection{Esclarecimento prévio}

Deve ficar claro desde já que a expressão "direitos sociais" é utilizada neste trabalho para fazer menção a um grupo de direitos humanos fundamentais surgido historicamente nos séculos XIX e XX, tendo como principais beneficiários os trabalhadores, como fruto de longo processo de lutas pelo reconhecimento dessa categoria específica de pessoas como sujeitos de direito.

Ou seja, a expressão nomina uma dimensão própria de direitos humanos fundamentais, a segunda na ordem de surgimento e positivação históricos.

Trata-se de um conceito restrito de "direito social" normas jurídicas voltadas à proteção dos trabalhadores, não se referindo, portanto, ao seu

\footnotetext{
${ }^{44}$ Um apanhado muito bem elaborado de tal dinâmica é dado por José Afonso da Silva: "Todos esses fundamentos foram sendo superados pelo processo histórico-dialético das condições econômicas, que deram nascimento a novas relações objetivas com o desenvolvimento industrial e o aparecimento de um proletariado amplo sujeito ao domínio da burguesia capitalista. Essas novas condições materiais da sociedade teriam que fundamentar a origem de outros direitos fundamentais - os direitos econômicos e sociais - e concomitantemente a transformação do conteúdo dos que serviam à burguesia em sua luta contra o absolutismo. Daí também sobreviriam novas doutrinas sociais, postulando a transformação da sociedade no sentido da realização ampla e concreta desses direitos. Essas novas fontes de inspiração dos direitos fundamentais são: (1) o Manifesto Comunista e as doutrinas marxistas, com sua crítica ao capitalismo burguês e ao sentido puramente formal dos direitos do homem proclamados no século XVIII, postulando liberdade e igualdade materiais num regime socialista; (2) a doutrina social da Igreja, a partir do Papa Leão XIII, que teve especialmente o sentido de fundamentar uma ordem mais justa, mas ainda dentro do regime capitalista, evoluindo, no entanto, mais recentemente, para uma Igreja dos pobres que aceita os postulados sociais marxistas; (3) o intervencionismo estatal, que reconhece que o Estado deve atuar no meio econômico e social, a fim de cumprir uma missão protetora das classes menos favorecidas, mediante prestações positivas, o que é ainda manter-se no campo capitalista com sua inerente ideologia de desigualdades, injustiças e até crueldades". SILVA, José Afonso da. op. cit., p. 174-175.

${ }^{45}$ Para um maior aprofundamento sobre a evolução histórica ocorrida nos séculos XIX e primeira metade do $\mathrm{XX}$, que culminou com o surgimento, sedimentação e positivação dos direitos sociais como direitos humanos fundamentais de segunda dimensão, confiram-se: i) PINTO, Airton Pereira. Direito do trabalho, direitos humanos sociais e a Constituição Federal. 1. ed. São Paulo: LTr, 2006. p. 63-72; ii) SARLET, Ingo Wolfgang. A eficácia dos direitos fundamentais, cit., p. 56-58; iii) FERREIRA FILHO, Manoel Gonçalves. op. cit., p. 59-65; iv) MARMELSTEIN, George. op. cit., p. 44-48.

46"Por Direito Social Restrito ou Direito Social 'tout court', compreendemos: 'a ciência dos princípios e leis geralmente imperativas, cujo objetivo imediato é, tendo em vista o bem comum, auxiliar as pessoas físicas, dependentes do produto de seu trabalho para a subsistência própria e de suas famílias, a satisfazerem convenientemente suas necessidades vitais e a terem acesso à propriedade privada". CESARINO JUNIOR, Antônio Ferreira. op. cit., p. 42.
} 
conceito amplo, qual seja, de direito como regulação do comportamento humano ${ }^{47}$.

Nesse diapasão, vale recordar antiga crítica à adoção da expressão ${ }^{48}$, na medida em que todo direito é social, pois o ser humano vive em sociedade e os comportamentos humanos relevantes para o direito são, em sua esmagadora maioria, aqueles praticados por mais de uma pessoa, por meio de relações interpessoais ${ }^{49}$.

Não obstante, é de se ressaltar o uso consagrado de tal expressão dentro do estudo dos direitos humanos fundamentais, forma pela qual a mesma também é por mim utilizada.

Estou de acordo, assim, com as razões apontadas por Antônio Ferreira Cesarino Júnior como aptas a justificar o emprego da expressão "direito social" em nosso meio jurídico:

\begin{abstract}
Ora, a bibliografia da disciplina mostra que não são tão poucos os autores que adotam o nome 'Direito Social'. A alegada ambiguidade do qualificativo social não existe nas demais expressões em que ele figura (questão social, política social, previdência social, etc.). Por que existiria somente na denominação Direito Social? Ademais é ele essencialmente antiindividualista e foi, historicamente pelo menos, direito autônomo, representando o exemplo mais completo da socialização do direito, o que lhe justifica a denominação social, muito embora todo direito se socialize! Na realidade, a economia, a política social e a sociologia aplicada não são ciências jurídicas, mas se tornam tais quando seus ensinamentos são formulados em normas legais, como acontece no que chamamos Direito Assistencial. Aliás, a denominação Direito Social é mais compreensível e tem sujeitos próprios, os economicamente débeis, que
\end{abstract}

47،"Por Direito Social Genérico, entendemos o sentido social que hoje domina todo o Direito, levando alguns autores a falar numa 'socialização do Direito', e o definimos: 'complexo de princípios e normas imperativas que têm por objeto a adaptação da forma jurídica à realidade social, considerando os homens na sua personalidade concreta e como membros dos grupos sociais diferentes do Estado e, tendo em vista, principalmente, as diferenças de situação econômica entre eles existentes"”. CESARINO JUNIOR, Antônio Ferreira. op. cit., p. 42.

48“Objeções à denominação Direito Social são sintetizadas por Evaristo de Moraes Filho: 1) contam-se a dedo os autores que adotam essa nomenclatura; 2) o qualificativo social é ambíguo, excessivamente genérico e equívoco; 3) usa-se muito a expressão social em oposição ao direito individual; 4) o chamado direito social é uma das manifestações da socialização do direito e não todo ele; 5) direito social tem também o sentido de exteriorização jurídica de corpos sociais autônomos, tais como os sindicatos e outros, independentes de sanção expressa e direta da vontade do Estado; 6) compreender o Direito Social como nós o fazemos é estender demasiado o campo do Direito do Trabalho, invadindo os domínios da economia, da política social e da sociologia aplicada; 7) na denominação direito social a qualificação não pode ser aplicada nem a um círculo de pessoas, nem a determinados estados de fato ou a diferenças específicas”. Id. Ibid., p. 37.

49“'Direito Social e Legislação Social incidem na arguição de que todo o direito é naturalmente social, pois só há Direito em sociedade: Ubi societas, ibi jus. Respondem seus partidários que o termo 'social', na denominação, visa opor esta disciplina ao direito individualista, oriundo da Revolução Francesa, significando predominância do interesse coletivo sobre o individual. Têm razão, embora hoje 'todo o direito' se socialize, se imbua de sentido social, como tão bem demonstram Le Fur, Josserand e Radbruch. Apesar do sentido social da 'Humanização do Direito' ser comum a todos os seus ramos, ele se acentuou, se concentrou no ramo dos conhecimentos chamados Legislação ou Direito Social. Daí existir o Direito Social lato sensu ou Direito Social Genérico e o Direito Social stricto sensu, Direito Social Restrito ou Direito Social propriamente dito, por abreviação, Direito Social'”. Id. Ibid., p. 33-34. 
chamamos hipossuficientes, e se refere a um estado de fato determinado, a hipossuficiência ou debilidade econômica ${ }^{50}$.

\subsubsection{Direitos sociais para fins deste trabalho}

No tocante ao seu conceito ${ }^{51}$, deve-se entender os direitos sociais como um feixe de direitos humanos fundamentais de segunda dimensão, surgidos historicamente entre os séculos XIX e primeira metade do XX, tendo como grande beneficiária a classe operária, voltados à implementação das condições materiais necessárias ao efetivo gozo dos direitos de liberdade e de igualdade pelos seres humanos ${ }^{52}$. $^{53}$

\footnotetext{
${ }^{50}$ CESARINO JUNIOR, Antônio Ferreira. op. cit., p. 37.

${ }^{51}$ Meu conceito de direito social está inegavelmente inserido dentro da tradição kantiana de direitos humanos fundamentais, de índole individualista, tendo no homem o centro dos ordenamentos jurídicos estatais (homem como sujeito de direitos). Para um conceito coletivo, sob o enfoque da sociedade, confira-se GURVITCH, Georges. L'idée du droit social. Paris: Scientia Verlag Aalen, 1972. Sua definição de direito social é a seguinte: "O direito social é um direito autônomo de comunhão, integrando de uma forma objetiva cada totalidade ativa real, que encarna um valor positivo atemporal. Este direito advém diretamente do 'todo' em questão para regular-lhe a vida interna, independentemente do fato de que este 'todo' seja organizado ou não. O direito de comunhão faz participar o 'todo' de uma forma imediata na relação jurídica que dele resulta, sem transformar este 'todo' em um sujeito distinto dos seus membros. O 'direito de integração' institui um 'poder social' que não está essencialmente ligado a uma coação incondicionada e que pode se realizar plenamente na maior parte dos casos através de uma coação relativa à qual se pode subtrair; sob certas condições este poder social funciona, às vezes, mesmo sem coação. $\mathrm{O}$ direito social precede, na sua camada primária, toda organização do grupo e não pode se exprimir de uma forma organizada a não ser que a associação esteja fundada sobre o direito da comunidade objetiva subjacente, quer dizer, ao mesmo tempo em que constitui uma associação igualitária de colaboração e não uma associação hierárquica de dominação. $O$ direito social se dirige, na sua camada organizada, a sujeitos jurídicos específicos - pessoas coletivas complexas - tão diferentes dos sujeitos individuais isolados quanto das pessoas morais - unidades simples - que absorvem a multiplicidade de seus membros na vontade única da corporação ou da organização". Id. Ibid., p. 15-16 (tradução do original, em francês). Na doutrina pátria, confira-se: MORAIS, Jose Luis Bolzan de. A ideia de direito social: o pluralismo jurídico de Georges Gurvitch. Porto Alegre: Livr. do Advogado, 1997.

${ }^{52}$ Confira-se o conceito trazido por José Afonso da Silva: “Assim, podemos dizer que os direitos sociais, como dimensão dos direitos fundamentais do homem, são prestações positivas proporcionadas pelo Estado direta ou indiretamente, enunciadas em normas constitucionais, que possibilitam melhores condições de vida aos mais fracos, direitos que tendem a realizar a igualização de situações sociais desiguais. São, portanto, direitos que se ligam ao direito de igualdade. Valem como pressupostos do gozo dos direitos individuais na medida em que criam condições materiais mais propícias ao auferimento da igualdade real, o que, por sua vez, proporciona condição mais compatível com o exercício efetivo da liberdade." SILVA, José Afonso da. op. cit., p. 286-287.

${ }^{53}$ Confira-se importante e esclarecedora conceituação trazida por Sérgio Pinto Martins: "Os direitos do segundo grupo são os direitos econômicos, sociais e culturais, bem como os direitos coletivos e das coletividades. Decorrem do princípio da igualdade. É a ideia do Estado do Bem-Estar Social, com caráter individualista. Visa-se corrigir questões sociais e econômicas decorrentes da Revolução Industrial. São direitos de crédito contra o Estado, exigindo prestações positivas. O Estado passa a intervir nas áreas econômica e social. No Brasil, são encontrados nos governos totalitários e nos militares. Na Europa, são observados no período pós guerra. Celso Lafer afirma que os direitos do segundo grupo 'buscam assegurar as condições para o pleno exercício do primeiro, eliminando ou atenuando os impedimentos ao pleno uso das capacidades humanas. Por isso, os direitos de crédito, denominados direitos econômico-sociais e culturais, podem ser encarados como direitos que tornam mais reais direitos formais: procuram garantir a todos o acesso aos meios de vida e de trabalho num sentido amplo". MARTINS, Sérgio Pinto. Direitos fundamentais trabalhistas, cit., p. 57. Para maior aprofundamento, confira-se: LAFER, Celso. A reconstrução dos direitos humanos: um diálogo com o pensamento de Hannah Arendt. 6. reimp. São Paulo: Companhia das Letras, 2006. p. 125-131.
} 
Veja que tais direitos, ao invés de se contraporem aos direitos de primeira dimensão, na verdade complementam-nos, ampliando o rol de seus beneficiários, já que possuem por escopo a criação das necessárias condições econômicas, políticas e educacionais para que a classe operária também possa gozar dos direitos de liberdade e igualdade.

É um claro movimento de ampliação dos direitos humanos fundamentais, tanto em número de direitos assegurados quanto em número de pessoas beneficiadas.

A chave mestra para se entender o conceito e alcance de tais direitos é a da igualdade material, a qual, contrariamente à igualdade meramente formal, exige a atuação estatal no sentido de se criarem as condições materiais necessárias ao surgimento da efetiva igualdade entre os seres humanos.

Já a igualdade formal, defendida e conquistada pela burguesia no século XVIII, inserida dentre os direitos humanos fundamentais de primeira dimensão, exige unicamente a edição de leis gerais e abstratas (igualdade perante a lei) que imponham limites ao poder estatal nas suas intervenções sobre as pessoas.

É de tais constatações que se sacam diferenciações como: i) igualdade perante a lei (igualdade formal) X igualdade na lei (igualdade material); ii) Estado de Direito Liberal X Estado de Direito Social; iii) Democracia Representativa X Democracia Participativa, dentre outras diferenciações, todas fruto da evolução social obtida mediante 0 reconhecimento dos direitos sociais, após mais um longo processo de lutas pelo reconhecimento da classe operária como sujeito de direitos fundamentais.

Importante destacar das conceituações apresentadas os caracteres intrínsecos aos direitos sociais: i) são prestações eminentemente positivas, ou seja, demandam um fazer por parte do Estado, no sentido da busca da igualdade material, que é sua mola propulsora; ii) possuem caráter agregador e complementar às liberdades públicas; iii) como direitos humanos fundamentais, são positivados nas Constituições dos Estados soberanos, o que realça a grande carga protetiva e de eficácia dos mesmos.

Nesse diapasão, algumas observações são extremamente relevantes, para que se evitem confusões ou mal entendidos ao longo da análise.

Já ficou bastante claro que os direitos sociais, como direitos humanos fundamentais de segunda dimensão, são fruto de um processo de expansão tendente à universalização dos direitos humanos fundamentais, reconhecendo a classe operária como sujeito de 
direitos após longo processo de lutas. Por isso mesmo são direitos que se somam aos direitos humanos fundamentais de primeira dimensão, complementando-os.

Tal caráter de complementaridade fica claro ao se verificar que, enquanto as liberdades públicas possuem como mola propulsora a efetivação do pilar da liberdade, mediante a imposição de limites ao poder estatal (prestações negativas perante o Estado), os direitos sociais possuem como mola propulsora a efetivação do pilar da igualdade, em seu aspecto material, mediante a imposição de prestações positivas perante o Estado ${ }^{54}$.

E a necessária relação entre o advento e positivação dos direitos humanos fundamentais sociais e o surgimento do Estado de Direito Social ${ }^{56}$, bem como a efetivação da igualdade material, é feita de forma cabal por Vicente de Paulo Barretto, que assinala:

Com a superação da ética liberal, o conceito de direitos fundamentais deixou de estar circunscrito ao status negativus libertatis, que vedava a interferência do Estado nas atividades da sociedade civil. A instituição dos direitos sociais supunha também a garantia do status positivus libertatis, que compreende o terreno das exigências, postulações e pretensões com que o indivíduo, dirigindose ao poder público, recebe em troca prestações. É, portanto, o status positivus que permite ao Estado construir socialmente as condições da liberdade concreta e efetiva. Deste modo, o Estado Social de Direito, substituindo o Estado Liberal, inclui no sistema de direitos fundamentais não só as liberdades clássicas, mas também os direitos econômicos, sociais e culturais. A satisfação de certas necessidades básicas e o acesso a certos bens fundamentais, para todos os membros da comunidade, passam a ser vistos como exigências éticas a que o Estado deve necessariamente responder ${ }^{57}$.

\footnotetext{
${ }^{54}$ Resumo bastante elucidativo de tal evolução é dado por José Joaquim Gomes Canotilho: "Se o capitalismo mercantil e a luta pela emancipação da $<<$ sociedade burguesa $>>$ são inseparáveis da consciencialização dos direitos do homem, de feição individualista, a luta das classes trabalhadoras e as teorias socialistas (sobretudo Marx em A Questão Judaica) põem em relevo a unidimensionalização dos direitos do homem $<<$ egoísta $>>$ e a necessidade de completar (ou substituir) os tradicionais direitos do cidadão burguês pelos direitos do $<<$ homem total $>>$, o que só seria possível numa nova sociedade. Independentemente da adesão aos postulados marxistas, a radicação da ideia da necessidade de garantir o homem no plano económico, social e cultural, de forma a alcançar um fundamento existencial-material, humanamente digno, passou a fazer parte do património da humanidade. As declarações universais dos direitos tentam hoje uma $<<$ coexistência integrada $>>$ dos direitos liberais e dos direitos sociais, económicos e culturais, embora o modo como os estados, na prática, asseguram essa imbricação, seja profundamente desigual". CANOTILHO, José Joaquim Gomes. op. cit., p. 385-386.

${ }^{55}$ Para um maior aprofundamento sobre o assunto, confira-se a obra de Jorge Reis Novais Direitos sociais: teoria jurídica dos direitos sociais enquanto direitos fundamentais. 1. ed. Coimbra: Coimbra Ed., 2010, Capítulo 1, p. 17-35; também José Afonso da Silva, Curso de direito constitucional positivo, cit., p. 184185. Para um enfoque filosófico da questão, confira-se o artigo de José Reinaldo de Lima Lopes intitulado Direito subjetivo e direitos sociais: o dilema do Judiciário no Estado Social de Direito. In: FARIA, José Eduardo (Org.). Direitos humanos, direitos sociais e justiça. 1. ed. 5. tir. São Paulo: Malheiros Ed., 2010. p. 113-143.

${ }^{56}$ Para um maior aprofundamento da questão, confira-se SARLET, Ingo Wolfgang; MARINONI, Luiz Guilherme; MITIDIERO, Daniel. Curso de direito constitucional. 1. ed. 2 tir. São Paulo: Ed. Revista dos Tribunais, 2012. p. 258-262.

${ }^{57}$ BARRETTO, Vicente de Paulo. Reflexões sobre os direitos sociais. In: SARLET, Ingo Wolfgang (Org.). Direitos fundamentais sociais: estudos de direito constitucional, internacional e comparado. Rio de Janeiro: Renovar, 2003. p. 128-130.
} 
Há que se acabar, portanto, com aquele ranço, enraizado na prática doutrinária, de considerar os direitos humanos fundamentais sociais como uma segunda categoria, inferiorizada, de direitos da pessoa humana, preocupação que está na base da obra de Jorge Reis Novais, intitulada "Direitos Sociais: Teoria Jurídica dos Direitos Sociais enquanto Direitos Fundamentais" 58 .

Outro equívoco frequente, que deve ser afastado, é o de se considerar as liberdades públicas como direitos humanos fundamentais exclusivamente negativos, e os direitos sociais como exclusivamente positivos.

Não obstante cada qual realmente tenha características próprias, o que justifica a inserção de cada categoria em uma dimensão diversa, o fato é que ambas as dimensões possuem carga negativa e positiva, impondo, de acordo com as características próprias de cada espécie de direito inserida no feixe, um grau variado de componente negativo e positivo.

O que está por trás de tal constatação é o fato de os direitos humanos fundamentais se submeterem a um mesmo regime jurídico protetivo, dotado de funções, ou seja, de objetivos e razões de ser, magistralmente apontadas por Canotilho da seguinte forma: i) função de defesa ou de liberdade, tradicionalmente conhecida como negativa, limitadora dos poderes estatais; ii) função de prestação social, tradicionalmente conhecida como positiva, a impor o dever estatal de realização de prestações de fazer; iii) função de proteção perante terceiros, e que traz à tona a questão dos efeitos horizontais dos direitos humanos fundamentais, ou seja, perante terceiros; iv) função de não discriminação ${ }^{59}$.

Quais são as espécies de direitos sociais integrantes dessa segunda dimensão de direitos humanos fundamentais?

\footnotetext{
${ }^{58}$ Confira-se advertência feita no início de sua introdução: “Apesar de a Constituição portuguesa ter optado pela consagração expressa de um vasto elenco de direitos sociais na qualidade de direitos fundamentais, são escassas ou contraditórias as consequências normativas que se têm retirado de tal opção. Ao longo de mais de três décadas de vigência da Constituição, o tom geral da caracterização doutrinária e jurisprudencial dos direitos sociais tem sido marcado por uma sua evidente secundarização, como se aquela afirmação constitucional, todavia inequívoca, não passasse de uma proclamação política ou de mero cumprimento retórico de um ritual politicamente correcto, mas dogmaticamente inconseqüente. O presente trabalho, partindo dessa verificação, preocupa-se, de um lado, com a evidenciação dos equívocos, debilidades e contradições que subjazem a uma tal menorização dos direitos sociais, mas, de outro, e sobretudo, assume-se como contributo na prossecução de um objectivo partilhado, actualmente, nas mais diversas latitudes: o da reabilitação dogmática dos direitos sociais como direitos fundamentais”. NOVAIS, Jorge Reis. op. cit., p. 9.

${ }^{59}$ CANOTILHO, José Joaquim Gomes. op. cit., p. 407-410. Voltarei ao tema com mais vagar e profundidade quando analisar a questão atinente à proteção jurisdicional dos direitos humanos fundamentais sociais (Capítulo 5).
} 
A espécie de direito social mais importante, verdadeiro pilar dos direitos sociais, seja porque foi o primeiro a surgir e a ser positivado, seja porque foi o direito social que mais demandou lutas pelo reconhecimento, seja por ser o direito diretamente ligado à classe operária, é o direito ao trabalho ${ }^{60}$.

Os demais direitos inseridos no feixe dos direitos humanos fundamentais sociais surgiram e foram positivados posteriormente, sempre relacionados à proteção dos trabalhadores, como mecanismos e condições necessários à garantia do direito ao trabalho, isto é, gravitam em torno do direito ao trabalho ${ }^{61}$.

No Brasil, classificação de grande utilidade acerca dos direitos sociais ${ }^{62}$ é dada por Sérgio Pinto Martins:

\begin{abstract}
Os direitos sociais são classificados em: (a) relativos ao trabalhador; (b) relativos à seguridade, compreendendo os direitos à saúde, à previdência e à assistência social; (c) relativos à educação e à cultura; (d) relativos à família, criança, adolescente e idoso; (e) relativos ao meio ambiente ${ }^{63}$. (grifado)
\end{abstract}

Já ficou claro que a previdência social, na qual estão inseridas as prestações estatais devidas em razão da ocorrência da contingência social da incapacidade laboral (objeto do presente estudo), é espécie de direito humano fundamental social, logo, beneficiando-se do regime jurídico protetivo dos direitos humanos fundamentais, inclusive, em termos de busca de sua máxima aplicação e efetividade, o que será objeto dos desdobramentos contidos nos próximos três capítulos (3 a 5).

\footnotetext{
${ }^{60}$ Tal é a conclusão cabal de Sérgio Pinto Martins: “A Revolução Francesa de 1848 e sua Constituição reconheceram o primeiro dos direitos econômicos e sociais: o direito ao trabalho. Foi imposta ao Estado a obrigação de dar meios ao desempregado de ganhar sua subsistência. Tem por base o trabalho (IV). Devem assegurar pelo trabalho os meios de vida (VII). A República deve proteger os cidadãos em seu trabalho, proporcionando-lhes trabalho nos limites dos seus recursos (VIII)." MARTINS, Sérgio Pinto. Direitos fundamentais trabalhistas, cit., p. 11.

${ }^{61}$ Conforme o escólio de Jorge Reis Novais, a doutrina tende a convergir para o seguinte núcleo de direitos como integrantes desse feixe constitutivo dos direitos humanos fundamentais sociais, em razão de suas características comuns, já apresentadas: “Assim, numa enumeração relativamente consolidada própria de Estado de Direito social, independentemente da diferenciação de positivação constitucional, consideraremos como direitos sociais como um todo (e é basicamente relativamente aos aqui enumerados que há um 'problema' de direitos sociais) integrantes daquele corpus os seguintes: um direito a um mínimo vital ou existencial (ou direito a um mínimo para uma existência condigna); um direito à saúde (ou à protecção da saúde); um direito à habitação (ou a uma habitação condigna); um direito à segurança social (ou à assistência social); um direito ao trabalho e um direito ao ensino (à educação ou à formação). Ou seja, independentemente da consagração constitucional positiva, é relativamente aos direitos integrantes deste corpus nuclear que se têm suscitado, ao longo de décadas intenso debate doutrinário e tratamento jurisprudencial, as dúvidas sobre a sua eventual natureza jusfundamental, sobre a sua justiciabilidade e alcance jurídico, sobre as diferenças ou especificidade de natureza que apresentam face aos direitos de liberdade". NOVAIS, Jorge Reis. op. cit., p. 40-41.

${ }^{62}$ Classificação muito próxima, a evidenciar a convergência da doutrina sobre o assunto, é dada por José Afonso da Silva, Curso de direito constitucional positivo, cit., p. 287.

${ }^{63}$ MARTINS, Sérgio Pinto. Direitos fundamentais trabalhistas, cit., p. 64.
} 


\subsection{Proteção jurídica}

Passo, a partir de agora, a abordar a abrangência atual dos direitos sociais, nos planos internacional e interno.

\subsubsection{Plano internacional}

Já a positivação e proteção dos direitos humanos fundamentais sociais no plano

internacional representaram processo histórico mais tardio, também fundamento e pilar da afirmação do Direito Internacional como formador de um verdadeiro ordenamento jurídico ${ }^{64}$.

Tal processo representou, na verdade, a inclusão da pessoa humana como sujeito de direitos no plano internacional, já que, até então, somente os Estados Soberanos e Organizações Internacionais eram reconhecidos como sujeitos de Direito Internacional.

Seu escopo nítido foi o de complementar e reforçar a positivação e proteção já previstas nas ordens jurídicas internas ${ }^{65}$, diante de eventos históricos catastróficos, dos quais a Segunda Guerra Mundial é o maior exemplo em termos de violação aos direitos humanos fundamentais ${ }^{66}$.

\footnotetext{
${ }^{64} \mathrm{Um}$ excelente apanhado da evolução histórica do processo de reconhecimento e positivação, no plano internacional, dos direitos humanos fundamentais sociais é dado por Flávia Piovesan no artigo Proteção internacional dos direitos econômicos, sociais e culturais. In: SARLET, Ingo Wolfgang (Org.). Direitos fundamentais sociais: estudos de direito constitucional, internacional e comparado. Rio de Janeiro, Renovar, 2003. p. 233-261.

${ }^{65}$ Conforme observa Flávia Piovesan: "Importa esclarecer que a sistemática internacional de proteção dos direitos humanos, ao constituir uma garantia adicional de proteção, invoca dupla dimensão, enquanto: a) parâmetro protetivo mínimo a ser observado pelos Estados, propiciando avanços e evitando retrocessos no sistema nacional de direitos humanos; e b) instância de proteção dos direitos humanos, quando as instituições nacionais se mostram falhas ou omissas no dever de proteção desses direitos." PIOVESAN, Flávia. Direitos humanos e o direito constitucional internacional. 9. ed. São Paulo: Saraiva, 2008. p. 8. Para um maior aprofundamento sobre o regime jurídico de proteção internacional dos Direitos Humanos, confira-se: i) LEWANDOWSKI, Enrique Ricardo. Proteção dos direitos humanos na ordem interna $e$ internacional. 1. ed. Rio de Janeiro: Forense, 1984, capítulo IX; p. 139-179; ii) TRINDADE, Antônio Augusto Cançado. Tratado de direito internacional dos direitos humanos. 1. ed. Porto Alegre: Sergio Antonio Fabris, 1997. v. 1, capítulo IX; p. 353-397; iii) RAMOS, André de Carvalho. op. cit., Parte 1, Item 6; p. 49-70.

${ }^{66}$ Confira-se, a propósito, importante escólio de Flávia Piovesan: "A internacionalização dos direitos humanos constitui, assim, um movimento extremamente recente na história, que surgiu a partir do pósguerra, como resposta às atrocidades e aos horrores cometidos durante o nazismo. Apresentando o Estado como o grande violador de direitos humanos, a Era Hitler foi marcada pela lógica da destruição e da descartabilidade da pessoa humana, o que resultou no extermínio de onze milhões de pessoas. O legado do nazismo foi condicionar a titularidade de direitos, ou seja, a condição de sujeito de direitos, à pertinência a determinada raça - a raça pura ariana. No dizer de Ignacy Sachs, o século XX foi marcado por duas guerras mundiais e pelo horror absoluto do genocídio concebido como projeto político e industrial. (...) Nesse contexto, desenha-se o esforço de reconstrução dos direitos humanos, como paradigma e referencial ético a
} 
Realmente, a Declaração dos Direitos do Homem e do Cidadão, editada na França em 1789, previa unicamente direitos de liberdade, e ainda assim sem qualquer pretensão cogente perante os Estados soberanos.

O primeiro documento internacional que prevê expressamente liberdades públicas e direitos sociais com caráter cogente é a Declaração Universal dos Direitos Humanos, adotada pela Organização das Nações Unidas por meio da Resolução n. 217-A, de 10 de dezembro de 1948, estando os direitos sociais arrolados em seus artigos 22 a 28.

Por ser o objeto do presente estudo, é fácil perceber a previsão do direito humano fundamental à segurança social em mais de uma passagem da referida Declaração, notadamente nos seus artigos 22 e 25, item 1, que assim prescrevem:

\begin{abstract}
Artigo 22.
Todo ser humano, como membro da sociedade, tem direito à segurança social $\mathrm{e}$ à realização, pelo esforço nacional, pela cooperação internacional e de acordo com a organização e recursos de cada Estado, dos direitos econômicos, sociais e culturais indispensáveis à sua dignidade e ao livre desenvolvimento da sua personalidade. (grifado)
\end{abstract}

\title{
Artigo 25.
}

1. Todo ser humano tem direito a um padrão de vida capaz de assegurar a si e a sua família saúde e bem estar, inclusive alimentação, vestuário, habitação, cuidados médicos e os serviços sociais indispensáveis, e direito à segurança em caso de desemprego, doença, invalidez, viuvez, velhice ou outros casos de perda dos meios de subsistência fora de seu controle. (grifado)

Em um segundo momento, houve a adoção de uma Convenção Internacional específica, voltada exclusivamente à prescrição e proteção dos direitos humanos fundamentais sociais, qual seja, o Pacto Internacional dos Direitos Econômicos, Sociais e Culturais, aprovado pela Resolução n. 2.200-A, da ONU, datada de 16 de dezembro de 1966.

Diferentemente da Declaração Universal, de cunho mais declaratório e genérico, tal Pacto passa a prever obrigações e mecanismos expressos a serem adotados pelos Estados Membros com vistas à efetivação de tais direitos, sob pena de sanções, o que é evidenciado

orientar a ordem internacional contemporânea. Se a Segunda Guerra significou a ruptura com os direitos humanos, o pós-guerra deveria significar sua reconstrução.

Nasce ainda a certeza de que a proteção dos direitos humanos não deve se reduzir ao âmbito reservado de um Estado, porque revela tema de legítimo interesse internacional. Sob esse prisma, a violação dos direitos humanos não pode ser concebida como questão doméstica do Estado, e sim como problema de relevância internacional, como legítima preocupação da comunidade internacional. A necessidade de uma ação internacional mais eficaz para a proteção dos direitos humanos impulsionou o processo de internacionalização desses direitos, culminando na criação da sistemática normativa de proteção internacional, que faz possível a responsabilização do Estado no domínio internacional quando as instituições nacionais se mostram falhas ou omissas na tarefa de proteger os direitos humanos". PIOVESAN, Flávia. Direitos humanos e o direito constitucional internacional, cit., p. 118-119. 
pela própria linguagem utilizada nos diversos artigos, sempre trazendo expressões imperativas como "Os Estados Membros comprometem-se", ou "Os Estados Membros devem promover".

O direito à previdência social é expressamente garantido pelo que dispõe seu artigo 9': "Os Estados Membros no presente Pacto reconhecem o direito de toda pessoa à previdência social, inclusive ao seguro social".

A grande inovação trazida pelo Pacto Internacional dos Direitos Econômicos, Sociais e Culturais é a previsão de mecanismos de controle e efetivação de tais direitos, previstos em sua "Parte IV" (arts. 16 a 25), notadamente o envio de relatórios periódicos pelos Estados Membros à ONU e a outorga de poderes ao Conselho Econômico e Social para fiscalizar o cumprimento da Convenção Internacional por parte dos Estados Membros, podendo indicar sanções a serem impostas pela Assembleia Geral.

O terceiro passo dado rumo à maior abrangência e especificação do feixe de direitos humanos fundamentais sociais, inclusive em termos de efetividade, foi a edição da Declaração de Direitos Humanos de Viena, de junho de 1993.

Trata-se de um documento muito mais amplo, pormenorizado e abrangente, que não só enuncia direitos sociais, mas também se preocupa com a criação de órgãos voltados à promoção e efetivação de tais direitos ao redor do mundo, além de esmiuçar o sentido e alcance de cada direito social específico.

Possui enorme importância no sentido de reconhecer e positivar, no plano internacional, os caracteres intrínsecos aos direitos humanos fundamentais, a saber:

\footnotetext{
5. Todos os Direitos Humanos são universais, indivisíveis, interdependentes e inter-relacionados. A comunidade internacional deve considerar os Direitos Humanos, globalmente, de forma justa e equitativa, no mesmo pé e com igual ênfase. Embora se deva ter sempre presente o significado das especificidades nacionais e regionais e os diversos antecedentes históricos, culturais e religiosos, compete aos Estados, independentemente dos seus sistemas políticos, econômicos e culturais, promover e proteger todos os Direitos Humanos e liberdades fundamentais. (grifado)
}

Observe, pois, que o reconhecimento, a positivação, a proteção e a efetividade dos direitos humanos fundamentais no plano internacional, inclusive, dos direitos sociais, são fenômenos relativamente recentes em nossa história, porém, em um inegável processo de ampliação e especificação, de modo a considerar cada direito integrante do feixe de 
direitos fundamentais dentro de suas especificidades, com o claro objetivo de incremento em sua proteção e efetividade ${ }^{67}$.

Também é de extremo relevo o reconhecimento expresso, no plano internacional, da inexistência de graus diversos de importância entre os direitos humanos fundamentais, estando todos "no mesmo pé e com igual ênfase". Isso significa ultrapassar antiga disputa doutrinária acerca da prevalência (ou não) das liberdades públicas sobre os direitos sociais, assunto já abordado e que ainda será retomado no Capítulo 5, quando tratar da justiciabilidade dos direitos sociais, exatamente para criticar a injustificável persistência de tal celeuma, a qual não possui mais razão de $\operatorname{ser}^{68}$.

Os atuais níveis de positivação, proteção e coerção impostos aos Estados Membros em termos de reconhecimento dos direitos humanos fundamentais (inclusive sociais) também permitem afirmar a existência de um verdadeiro Direito Constitucional Internacional, como nível superior de positivação no plano internacional, constituindo o seu ápice; assim como se dá no plano interno de cada Estado soberano, os direitos humanos fundamentais funcionam igualmente como pilar e mola propulsora de um movimento que, além de propiciar a interação entre os planos interno e internacional de proteção dos direitos humanos fundamentais, reforçam-se mutuamente ${ }^{69}$.

\footnotetext{
${ }^{67}$ Trata-se de fenômeno muito bem percebido por Bobbio: "Além dos processos de conversão em direito positivo, de generalização e de internacionalização, aos quais me referi no início, manifestou-se nestes últimos anos uma nova linha de tendência, que se pode chamar de especificação; ela consiste na passagem gradual, porém, cada vez mais acentuada, para uma ulterior determinação dos sujeitos titulares de direitos. Ocorreu, com relação aos sujeitos, o que desde o início ocorrera com relação à ideia abstrata de liberdade, que se foi progressivamente determinando em liberdades singulares e concretas (de consciência, de opinião, de imprensa, de reunião, de associação), numa progressão ininterrupta que prossegue até hoje: basta pensar na tutela da própria imagem diante da invasão dos meios de reprodução e difusão de coisas do mundo exterior, ou na tutela da privacidade diante do aumento da capacidade dos poderes públicos de memorizar nos próprios arquivos os dados privados da vida de cada pessoa. Assim, com relação ao abstrato sujeito 'homem', que já encontrara uma primeira especificação no 'cidadão' (no sentido de que podiam ser atribuídos ao cidadão novos direitos com relação ao homem em geral), fez-se valer a exigência de responder com nova especificação à seguinte questão: que homem, que cidadão?” BOBBIO, Norberto. op. cit.

${ }^{68}$ Tem plena razão Jorge Reis Novaes quando afirma: “Assim, entre nós, os direitos sociais, sendo direitos fundamentais constitucionais, gozam, portanto, à partida, do regime dos direitos fundamentais enquanto normas jurídicas vinculativas de força superior e gozam desse regime relativamente a todo o seu conteúdo, tal como os direitos de liberdade, e não apenas relativamente a um dificilmente delimitável 'mínimo social'." NOVAIS, Jorge Reis. op. cit., p. 84.

${ }^{69}$ Confira-se, a propósito, a seguinte observação feita por Flávia Piovesan: "Por sua vez, o Direito Internacional dos Direitos Humanos, ao concentrar seu objeto nos direitos da pessoa humana, revela um conteúdo materialmente constitucional, já que os direitos humanos, ao longo da experiência constitucional, sempre foram considerados matéria constitucional. Contudo, no âmbito do Direito Internacional dos Direitos Humanos, a fonte de tais direitos é de natureza internacional. O enfoque da investigação é, assim, interdisciplinar, já que se localiza justamente na interação entre o Direito Constitucional e o Direito Internacional dos Direitos Humanos. A interdisciplinaridade aponta para uma resultante: o chamado Direito Constitucional Internacional. Por Direito Constitucional Internacional subentende-se aquele ramo do Direito no qual se verifica a fusão e a interação entre o Direito Constitucional e o Direito Internacional,
} 


\subsubsection{Plano interno}

A positivação dos direitos sociais nos ordenamentos jurídicos internos seguiu a mesma lógica de positivação da primeira dimensão de direitos humanos fundamentais (liberdades públicas), qual seja: deu-se por meio de sua fixação e proteção em nível constitucional, no ápice do ordenamento jurídico de cada Estado.

Já foi afirmado no Capítulo 1, e será demonstrado de forma pormenorizada no Capítulo 3, que a história da positivação dos direitos humanos fundamentais serviu de mola propulsora ao próprio movimento constitucionalista, como um dos mais importantes pilares e causas para a formalização de um documento jurídico alçado ao ápice do ordenamento jurídico estatal.

No Brasil não foi diferente, sendo que a vigente Constituição, de 1988, corporifica o auge de um modelo de Estado Social Democrático de Direito, de nítido cunho assistencialista, em que os direitos humanos fundamentais, inclusive sociais, ocupam importantíssimo lugar, expressamente citados no seu preâmbulo (“destinado a assegurar o exercício dos direitos sociais e individuais"), dentre os seus princípios (art. $1^{\circ}$, inciso IV) e objetivos (art. $3^{\circ}$, incisos I, III e IV) fundamentais, além de figurarem dentre os princípios que regem as relações internacionais (art. $4^{\circ}$, inciso II).

Ademais, seu artigo $5^{\circ}$ arrola um grande número de direitos individuais e coletivos, notadamente de primeira dimensão, sendo que os artigos $6^{\circ}$ a 11 arrolam diversos direitos sociais, de segunda dimensão, direitos esses pormenorizados em termos de regime jurídico em seu Título VIII, que trata "Da Ordem Social” (arts. 193 a 232), o qual traz, inclusive, direitos enquadrados na terceira dimensão, como é o caso do direito ao meio ambiente (art. 225).

Trata-se de um verdadeiro Estado de Bem Estar Social tardio, cujo modelo foi desenvolvido na Europa durante o período pós $2^{\mathrm{a}}$ Guerra Mundial e que teve seu auge nas

\footnotetext{
interação que assume um caráter especial quando esses dois campos do direito buscam resguardar um mesmo valor - o valor da primazia da pessoa humana -, concorrendo na mesma direção e sentido. Ao tratar da dinâmica da relação entre a Constituição brasileira e o sistema internacional de proteção dos direitos humanos, objetiva-se não apenas estudar os dispositivos do Direito Constitucional que buscam disciplinar o Direito Internacional dos Direitos Humanos, mas também desvendar o modo pelo qual este último reforça os direitos constitucionalmente assegurados, fortalecendo os mecanismos nacionais de proteção dos direitos da pessoa humana. Isto é, o trabalho se atém à dialética da relação entre Constituição e Direito Internacional dos Direitos Humanos, na qual cada um dos termos da relação interfere no outro, com ele interagindo". PIOVESAN, Flávia. Direitos humanos e o direito constitucional internacional, cit., p. 16-17.
} 
décadas de 50 a 70, sofrendo posterior declínio em razão do grande endividamento dos Estados para a efetivação dos direitos sociais, custosos por natureza ${ }^{70}$.

Dentre os direitos inseridos no rol constitucional brasileiro de direitos sociais encontramos, no artigo $6^{\circ}$, "a educação, a saúde, a alimentação, o trabalho, a moradia, o lazer, a segurança, a previdência social, a proteção à maternidade e à infância e a assistência aos desamparados"71.

Embora não seja assunto a ser abordado neste momento, mas apenas para demonstrar a elevada carga cogente de tais direitos, além de seu elevado grau de proteção, deve ser mencionado que a Constituição brasileira de 1988, altamente inspirada na portuguesa de 1976, bem como em outras constituições europeias, prevê expressamente que: i) o rol de direitos humanos fundamentais representativos de cada dimensão não é exaustivo, não excluindo "outros decorrentes do regime e dos princípios por ela adotados, ou dos tratados internacionais em que a República Federativa do Brasil seja parte" (art. $5^{\circ}$, $\S 2^{\circ}$ ); ii) "as normas definidoras dos direitos e garantias fundamentais têm aplicação imediata" (art. $5^{\circ}, \S 1^{\circ}$ ), ou seja, não dependem de prévia regulamentação pelo legislador ordinário para irradiar efeitos jurídicos.

Esta última regra, da aplicação imediata das normas jurídicas constitucionais consagradoras de direitos humanos fundamentais, vai ao encontro do conceito formal de direitos humanos fundamentais dado por Robert Alexy: "Pode-se dizer que os direitos fundamentais da Constituição alemã são posições que, do ponto de vista do direito

\footnotetext{
${ }^{70}$ Para uma importante visão histórica do surgimento do Estado de Bem Estar Social, dentro da lógica da constitucionalização dos direitos humanos fundamentais sociais, confira-se artigo escrito por Carlos Miguel Herrera, Estado, Constituição e direitos sociais. In: SOUZA NETO, Claudio Pereira de; SARMENTO, Daniel (Orgs.). Direitos sociais: fundamentos, judicialização e direitos sociais em espécie. Rio de Janeiro: Lumen Juris, 2008. p. 5-24.

${ }^{71}$ Importantíssima é a advertência feita por Jorge Reis Novais no tocante ao caráter jusfundamental dos direitos sociais nos países em que os mesmos são expressamente previstos como direitos humanos fundamentais pelas respectivas constituições (caso brasileiro), hipótese em que não há espaço para maiores disputas, não sendo válida a simples importação do modelo alemão, cuja constituição não apresenta um rol de direitos sociais: "Com efeito, quando uma Constituição consagra e reconhece inequivocamente os direitos sociais como direitos fundamentais, elencando-os, de resto, de forma muito pormenorizada e desenvolvida, toda a discussão sobre a sua controversa natureza jusfundamental perde grande parte do sentido. Portanto, se, como acontece entre nós, o legislador constituinte, atendendo à respectiva fundamentalidade no quadro de um Estado social e democrático de Direito, intencionalmente acolhe os direitos sociais como direitos fundamentais, podemos discutir o alcance desse reconhecimento, podemos discutir o que significa ser um direito fundamental, mas deixa de fazer sentido consumir o essencial dos esforços dogmáticos a apurar se há ou não, e com que fundamentos, direitos constitucionais sociais." NOVAIS, Jorge Reis. op. cit., p. 84.
} 
constitucional, são tão importantes que a decisão sobre garanti-las ou não garanti-las não pode ser simplesmente deixada para a maioria parlamentar simples". ${ }^{72}$

\subsection{Eficácia}

Por fim, passo a analisar, mesmo que de forma sucinta, a questão atinente à eficácia ${ }^{73}$ dos direitos humanos fundamentais sociais, iniciando pelo plano internacional.

\subsubsection{Plano internacional}

No atual estágio de evolução da positivação dos direitos humanos fundamentais sociais no plano internacional pode-se dizer que o caminho percorrido tem sido de um paulatino incremento: i) do número de direitos sociais protegidos por meio de Convenções Internacionais; ii) dos mecanismos de proteção dos direitos sociais, seja via positivação de sanções, seja via criação de Tribunais e Órgãos internacionais voltados à apuração e aplicação de sanções aos Estados Membros violadores de tais direitos; iii) dos mecanismos de efetivação de tais direitos, notadamente por meio da criação de Organismos Internacionais voltados à implementação dos direitos sociais, com ênfase nos países subdesenvolvidos. ${ }^{74}$

A grande dificuldade enfrentada em termos de implementação dos direitos humanos fundamentais sociais no plano internacional é a mesma enfrentada pelos Estados Soberanos no plano interno: o fato de se tratar de direitos prestacionais, logo, demandando uma série de processos e atividades estatais para sua efetivação, o que envolve altos custos financeiros.

\footnotetext{
${ }^{72}$ ALEXY, Robert. Teoria dos direitos fundamentais. Tradução de Virgílio Afonso da Silva. 2. ed. São Paulo: Malheiros Ed., 2011. p. 446-447.

${ }^{73}$ Verificar, a respeito, a Declaração de Direitos Humanos aprovada pela Convenção de Viena, de 1993, onde a preocupação com a instituição de mecanismos, órgãos e políticas públicas voltados à efetivação dos direitos humanos fundamentais sociais restou externada especialmente pelos seus itens 4, 13, 26, 27, 31 e 34. DECLARAÇÃO e Programa de Ação de Viena. Conferência Mundial sobre Direitos Humanos. Viena, 14-25 de Junho de 1993, cit.

${ }^{74}$ Para maior aprofundamento sobre a questão, confira-se: PIOVESAN, Flávia. Direitos humanos e o direito constitucional internacional, cit., Capítulo VI, p. 157-236.
} 
Mas isso apenas significa que tais direitos não podem ser implementados de uma só vez e em um único ato. Sua implementação paulatina é dever internacional e pode gerar sanções aos Estados Membros que descumprirem suas obrigações ${ }^{75}$.

\subsubsection{Plano interno}

Já no plano interno, especialmente no caso brasileiro, tem-se, hodiernamente, um sistema de proteção aos direitos humanos fundamentais (inclusive sociais) altamente desenvolvido.

Tal proteção se dá, basicamente, por meio de quatro pilares, a seguir explicitados.

O primeiro deles diz respeito à enumeração de uma série de direitos humanos

fundamentais no bojo da Constituição, como Lei Maior do País, logo, a orientar a produção legislativa do Parlamento, bem como a atuação dos demais Poderes estatais (Executivo e Judiciário).

Assim é que os direitos de primeira dimensão (liberdades públicas) estão arrolados no artigo $5^{\circ}$; os de segunda dimensão (direitos sociais) encontram-se positivados nos artigos $6^{\circ}$ a 11 , e melhor disciplinados em termos de regime jurídico nos artigos 193 a 232 (Título VIII da Constituição, "Da Ordem Social"); e os de terceira dimensão (direitos de solidariedade) encontram-se espraiados pela Constituição (p.e.: art. 225, direito ao meio ambiente).

\footnotetext{
${ }^{75}$ Tais conclusões não passaram despercebidas por Flávia Piovesan: "Contudo, reitera-se, o Pacto dos Direitos Econômicos, Sociais e Culturais estabelece a obrigação dos Estados de reconhecer e progressivamente implementar os direitos nele enunciados. Como afirma o Comitê sobre os Direitos Econômicos, Sociais e Culturais: 'Se a plena realização de relevantes direitos pode ser alcançada progressivamente, medidas nesta direção devem ser adotadas em um razoavelmente curto período de tempo, após o Pacto entrar em vigor em relação a determinado Estado. Estas medidas devem ser deliberadas e concretamente alcançáveis, da forma mais clara possível, no sentido de conferir cumprimento às obrigações reconhecidas no Pacto'. (...) Quanto ao debate sobre a acionabilidade dos direitos sociais, econômicos e culturais, compartilha-se da visão de que 'a insistência de que as Cortes são incompetentes para tratar de políticas sociais parece ignorar sua histórica e contínua intervenção nesta área. As Cortes criam políticas sociais não apenas quando interpretam a Constituição, mas também quando interpretam legislações de Direito econômico, trabalhista e ambientalista, dentre outras, assim como em suas resoluções em disputas privadas'. Acredita-se que a idéia da não-acionabilidade dos direitos sociais é meramente ideológica e não científica. É uma pré-concepção que reforça a equivocada noção de que uma classe de direitos (os direitos civis e políticos) merece inteiro reconhecimento e respeito, enquanto outra classe (os direitos sociais, econômicos e culturais), ao revés, não merece qualquer reconhecimento. Compartilha-se, pois, da noção de que os direitos fundamentais - sejam civis e políticos, sejam sociais, econômicos e culturais - são acionáveis e demandam séria e responsável observância". PIOVESAN, Flávia. Direitos humanos e o direito constitucional internacional, cit., p. 178-181.
} 
Essa função primordial de vinculação ${ }^{76}$ dos Poderes estatais com vistas à proteção e efetivação dos direitos humanos fundamentais em razão de sua positivação em nível constitucional $^{77}$ traz o segundo pilar de proteção de tais direitos, diretamente relacionado com o primeiro: a aplicabilidade imediata das normas constitucionais que versam sobre direitos fundamentais, conforme regra expressa do artigo $5^{\circ}, \S 1^{\circ}$, a saber: "As normas definidoras dos direitos e garantias fundamentais têm aplicação imediata".

Ou seja, as normas constitucionais veiculadoras de direitos humanos fundamentais não podem ser interpretadas como meramente programáticas, a depender do legislador ordinário para a produção de efeitos jurídicos, mas devem ser consideradas como normas jurídicas completas, vinculantes e produtoras de efeitos jurídicos de forma imediata, ou seja, a partir do início de sua vigência ${ }^{78} 79$.

O terceiro pilar diz respeito ao caráter meramente exemplificativo do rol dos direitos humanos fundamentais, o que é expresso no artigo $5^{\circ}, \S 2^{\circ}$, da Constituição, ao prescrever que "Os direitos e garantias expressos nesta Constituição não excluem outros decorrentes do regime e dos princípios por ela adotados, ou dos tratados internacionais em que a República Federativa do Brasil seja parte" ${ }^{\text {. }}$.

\footnotetext{
${ }^{76}$ Inescapável, uma vez mais, a conclusão no sentido de uma relação íntima e de mútua imbricação entre direitos humanos fundamentais e constitucionalismo. Ademais, sob o aspecto específico da vinculação dos Poderes estatais aos direitos humanos fundamentais em razão de sua positivação constitucional, é de se salientar o poder conferido ao Judiciário de controle de constitucionalidade das leis e atos normativos expedidos pelo Legislativo e Executivo, como garantia adicional à eficácia dos direitos humanos fundamentais, em razão da supremacia da constituição, noção que será retomada e aprofundada nos Capítulos 3 e 4.

${ }^{77}$ Para maior aprofundamento do assunto, confira-se: MARMELSTEIN, George. op. cit., p. 247-268.

${ }^{78}$ Confira-se, outrossim, Id. Ibid., p. 297-300.

${ }^{79}$ Tais pilares restaram argutamente percebidos por Ingo Wolfgang Sarlet: “Ao art. $5^{\circ}, \S 1^{\circ}$, da Constituição de 1988 é possível atribuir, sem sombra de dúvidas, o mesmo sentido outorgado ao art. 18/1 da Constituição da República Portuguesa e ao art. $1^{\circ}$, inc. III, da Lei Fundamental da Alemanha, o que, em última análise, significa - de acordo com a lição de Jorge Miranda - que cada ato (qualquer ato) dos poderes públicos deve tomar os direitos fundamentais como 'baliza e referencial'. Importante, ainda, é a constatação de que o preceito em exame fundamenta uma vinculação isenta de lacunas dos órgãos e funções estatais aos direitos fundamentais, independentemente da forma jurídica mediante a qual são exercidas estas funções, razão pela qual - como assevera Gomes Canotilho - inexiste ato de entidade pública que seja livre dos direitos fundamentais. Neste sentido, é possível falar de uma dupla significação da eficácia vinculante dos direitos fundamentais. Assim, se de acordo com um critério formal e institucional os detentores do poder estatal formalmente considerados (os órgãos dos Poderes Legislativo, Executivo e Judiciário) se encontram obrigados pelos direitos fundamentais, também num sentido material e funcional todas as funções exercidas pelos órgãos estatais o são. Por este motivo é que se aponta para a necessidade de todos os poderes públicos respeitarem o âmbito de proteção dos direitos fundamentais, renunciando, em regra, a ingerências, a não ser que presente justificativa que as autorize. Do efeito vinculante inerente ao art. $5^{\circ}, \S 1^{\circ}$, da CF decorre, num sentido negativo, que os direitos fundamentais não se encontram na esfera de disponibilidade dos poderes públicos, ressaltando-se, contudo, que, numa acepção positiva, os órgãos estatais se encontram na obrigação de tudo fazer no sentido de realizar os direitos fundamentais". SARLET, Ingo Wolfgang. A eficácia dos direitos fundamentais, cit., p. 389-390.

${ }^{80}$ Para aprofundamento do assunto, confira-se: MARMELSTEIN, George. op. cit., p. 204-212.
} 
Trata-se de expresso reconhecimento pelo constituinte do caráter evolutivo $e$ progressivo dos direitos humanos fundamentais, além de seu caráter de fundamentalidade, como pilar da civilização humana ${ }^{81}$.

$\mathrm{O}$ quarto pilar diz respeito à inserção das normas constitucionais relativas aos direitos humanos fundamentais dentre as chamadas "cláusulas pétreas" (art. $60, \S 4^{\circ}$, inciso IV, da Constituição), ou seja, são normas de especial envergadura constitucional, que não podem ser extirpadas da Constituição mesmo que por meio de Emendas Constitucionais $^{82}$.

Mais uma vez se vê o evidente caráter evolutivo dos direitos humanos fundamentais reconhecido pelo constituinte pátrio, sendo que tal proteção reforça, ademais, a consagrada teoria da vedação do retrocesso em termos de direitos humanos fundamentais, entendidos como conquista civilizatória.

Vedação esta evidenciada na medida em que, uma vez positivado, o direito humano fundamental não pode mais ser extirpado do texto constitucional, protegido que se encontra, inclusive, do constituinte derivado, pela garantia da "cláusula pétrea" 83 .

\footnotetext{
${ }^{81}$ Não obstante, é inegável a existência atual de enormes dificuldades doutrinárias para a enumeração dos direitos humanos fundamentais que não constam expressamente de normas constitucionais, o que restou reconhecido por Ingo Wolfgang Sarlet na seguinte passagem de sua obra: "Sem qualquer pretensão de esgotar o espectro temático com o qual nos deparamos, é de se referir que a doutrina ainda não se encontra completamente pacificada no que diz com posição assumida pelos direitos materialmente fundamentais (de modo especial os que não encontram assento na Constituição formal) com relação aos direitos do catálogo, isto é, se podem, ou não - e de que maneira -, ser equiparados no que tange ao seu regime jurídico. Outra questão crucial decorrente da abertura material do catálogo reside na dificuldade em identificar, no texto constitucional (ou mesmo fora dele), quais os direitos - e aqui deixamos de adentrar o terreno espinhoso da conceituação do termo 'direitos' - que efetivamente reúnem as condições para poder ser considerados materialmente fundamentais. Ponto que igualmente merece destaque é o que diz respeito às fontes dos direitos fundamentais fora do catálogo, que, ao menos em princípio, podem ter assento em outras partes do texto constitucional ou residir em outros textos legais nacionais ou internacionais. Além disso, há que considerar a problemática da abrangência da regra, visto que topograficamente situada no capítulo dos direitos individuais e coletivos, sendo, no mínimo, prudente a indagação a respeito da viabilidade de sua extensão aos direitos fundamentais econômicos, sociais e culturais, comumente e genericamente denominados de direitos sociais". SARLET, Ingo Wolfgang. A eficácia dos direitos fundamentais, cit., p. 95-96.

${ }^{82}$ Para aprofundamento do assunto, confira-se: MARMELSTEIN, George. op. cit., p. 269-286.

${ }^{83}$ Tal reforço protetivo não passou despercebido por Ingo Wolfgang Sarlet: "Em virtude tanto de sua especial posição na arquitetura constitucional, que, por sua vez, se manifesta mediante o que convencionamos considerar uma fundamentalidade formal e material, que outorga aos direitos fundamentais força jurídica reforçada relativamente às demais normas constitucionais, quanto da vinculação de todos, poderes públicos e particulares, aos direitos fundamentais, impõe-se que estes sejam devidamente protegidos, sob pena de esvaziar-se sua particular dignidade na ordem constitucional. Aliás, consoante assinalado alhures, verificou-se que um dos elementos caracterizadores da fundamentalidade em sentido formal, ao menos em nossa Constituição, é justamente a circunstância de terem os direitos fundamentais sido erigidos à condição de 'cláusula pétrea', integrando o rol do art. $60, \S 4^{\circ}$, inc. IV, da nossa Carta Magna, constituindo, portanto, limites materiais à reforma da Constituição. Ora, esta proteção jurídica reforçada, peculiar apenas aos direitos fundamentais e alguns poucos princípios escolhidos pelo Constituinte, não deixa de poder ser considerada um dos efeitos jurídicos gerados pelos direitos fundamentais e, portanto, uma dimensão de sua
} 
E que não pairem dúvidas acerca da inclusão dos direitos sociais no rol dos direitos humanos fundamentais protegidos pelos quatro pilares constitucionais erigidos pela vigente Ordem Constitucional de 1988, o que já restou demonstrado no Capítulo 1 por meio da comprovação da existência de um regime jurídico único para os direitos humanos fundamentais, integrado pelas três dimensões ${ }^{84}$.

Restou claro, do exposto, o elevado grau de proteção e eficácia dos direitos humanos fundamentais (inclusive sociais) nos planos internacional e brasileiro, o que também foi fruto de longa evolução histórica, cuja interface mais evidente será estudada no capítulo seguinte, qual seja, o surgimento e evolução do constitucionalismo, como movimento teórico criador de instrumentos jurídicos garantidores da máxima eficácia possível aos direitos humanos fundamentais, dentro de um regime jurídico único, a abarcar os direitos sociais ${ }^{85}$.

eficácia. Por outro lado, se até mesmo contra emendas à Constituição, expressão do Poder Constituinte Derivado ou Reformador, os direitos fundamentais se encontram protegidos (ainda que não de forma absoluta, como se verá), com ainda maior razão se justifica uma proteção contra uma eventual erosão por parte do legislador infraconstitucional, a quem incumbe, em princípio, a concretização e regulamentação dos direitos fundamentais, atividade na qual, muitas vezes, estes acabam sendo objeto de restrições em seu âmbito de proteção". SARLET, Ingo Wolfgang. A eficácia dos direitos fundamentais, cit., p. 408-409.

${ }^{84}$ Dentre os grandes doutrinadores defensores de tal inclusão, cito os seguintes: i) SILVA, José Afonso da. op. cit., p. 184-185; ii) SARLET, Ingo Wolfgang; MARINONI, Luiz Guilherme; MITIDIERO, Daniel. Curso de direito constitucional, cit., p. 130-138 e 313-319; iii) MORAES, Alexandre de. Direito constitucional, cit., p. 662-664; iv) MARMELSTEIN, George. op. cit., p. 271-274.

${ }^{85} \mathrm{Uma}$ interessante análise acerca da grande carga eficacial das normas constitucionais veiculadoras de direitos humanos fundamentais sociais, sob o prisma do Direito Administrativo, é trazida por Celso Antonio Bandeira de Mello em sua curta e elucidativa publicação intitulada Eficácia das normas constitucionais e direitos sociais. 1. ed. 3. tir. São Paulo: Malheiros Ed., 2011. 


\section{OS DIREITOS HUMANOS FUNDAMENTAIS COMO PREVISTOS E GARANTIDOS CONSTITUCIONALMENTE: A FORÇA NORMATIVA DA CONSTITUIÇÃO}

\subsection{Introdução}

Começo, agora, a analisar e demonstrar que a história do surgimento, da sedimentação, positivação e ampliação dos direitos humanos fundamentais (inclusive sociais) coincide com a história do surgimento, da sedimentação, positivação e ampliação das constituições, como documento normativo mais importante de cada Estado soberano, ápice do ordenamento jurídico estatal ${ }^{86}$ e corolário do movimento constitucionalista.

Ao final do processo, espero que fique claro que ambos - direitos humanos fundamentais e constituições - são responsáveis pelo surgimento e evolução do próprio Estado de Direito, em suas sucessivas modalidades, como principais mecanismos de garantia e proteção das pessoas em face do Estado e de terceiros, para que possam desenvolver ao máximo suas potencialidades, com a preservação de suas características intrínsecas.

Também são conquistas voltadas à garantia da sacralização da pessoa humana, dentro de um processo histórico de lutas pelo reconhecimento da pessoa humana como sujeito de direitos, conforme abordado no capítulo 1.

Entre eles, a relação é de meio (constituição) imprescindível à garantia do respeito e efetivação dos fins (direitos humanos fundamentais), moldando o Estado para que seja o principal motor do desenvolvimento da humanidade, tendo como resultado a obtenção paulatina de novos direitos humanos fundamentais como conquistas civilizatórias.

Por isso mesmo, não há como se falar de um (direitos humanos fundamentais, já abordados nos capítulos precedentes), sem mencionar o outro (constituição, a ser abordada

\footnotetext{
${ }^{86}$ Inconfundível definição trazida por Hans Kelsen, alçado ao posto de um dos maiores juristas do século XX pela quase unanimidade dos estudiosos do Direito, e cuja contribuição maior foi a construção da Teoria Pura do Direito, pela qual o ordenamento jurídico se encontra escalonado de forma piramidal, de modo que dada norma jurídica retire seu fundamento de validade de uma norma jurídica de maior escalão, até se chegar à "norma fundamental", no ápice do ordenamento jurídico estatal. Não obstante se enquadre dentre os filósofos positivistas do Direito, suas contribuições são até hoje imprescindíveis ao estudo da Ciência do Direito.
} 
nos capítulos 3 e 4 desta obra), demonstrando como ambos os institutos caminham juntos em prol da evolução da humanidade, estando umbilicalmente ligados.

Começo por esclarecer que, assim como ocorreu com os direitos humanos fundamentais, a história das constituições remonta à Idade Antiga, passando por lento desenvolvimento até desembocar em momentos históricos fulcrais, nos quais se afirma como instrumento de defesa e garantia dos cidadãos.

A partir de tal ponto, deixa de ser mera realidade fática, passando a instrumento jurídico introduzido nos diversos ordenamentos jurídicos ocidentais, fruto de longa evolução histórico-econômica-filosófica-social da humanidade, logo, sofrendo mutações e evoluções de acordo com as mudanças sofridas pela sociedade, a partir do século XVIII até nossos dias.

Interessante notar, desde logo, que o constitucionalismo, como ciência jurídica, somente surgiu após a positivação da primeira constituição (americana, datada de 1787 e ratificada pelo número mínimo de Estados em 1788), não obstante tal fenômeno já fosse conhecido e estudado desde antes da Grécia antiga ${ }^{87}$.

Isso só demonstra que, assim como os direitos humanos fundamentais, o fenômeno constitucional era, é e continuará sendo uma exigência intrínseca à raça humana, em termos de disciplina da vida em sociedade, buscando-se sempre uma conciliação no exercício das capacidades individuais em um patamar máximo que respeite, ao mesmo tempo, as demais pessoas, possibilitando a coexistência pacífica de todos.

Não é sem razão que a quase unanimidade dos constitucionalistas indique que uma carta constitucional (constituição como documento jurídico inserido como fundamento de validade máximo do ordenamento jurídico estatal; constituição em sentido formal) sempre possui três ordens de normas jurídicas: i) normas conformadoras do modelo e estrutura estatal adotados pela sociedade; ii) normas garantidoras de direitos humanos fundamentais; iii) normas fixadoras dos valores e fins públicos a serem perseguidos pela

\footnotetext{
${ }^{87}$ BARROSO, Luís Roberto. Curso de direito constitucional contemporâneo. 4. ed. São Paulo: Saraiva, 2013. p. 26-27. A propósito, confira-se: "O termo constitucionalismo é de uso relativamente recente no vocabulário político e jurídico do mundo ocidental. Data de pouco mais de duzentos anos, sendo associado aos processos revolucionários francês e americano. Nada obstante, as ideias centrais abrigadas em seu conteúdo remontam à Antiguidade Clássica, mais notadamente ao ambiente da Polis grega, por volta do século V a.C."
} 
estrutura estatal montada ${ }^{88}$ (normas estas configuradoras da constituição em sentido material).

Em resumo: uma constituição, em sentido material, é um sistema normativo ordenador e unificador do regime jurídico de dado Estado de Direito ${ }^{89}$, que geralmente vem instrumentalizado em uma carta constitucional (constituição formal).

\subsection{Evolução histórica do constitucionalismo}

Feita essa introdução sumária, passo a analisar a constituição sob o aspecto de sua evolução histórica ${ }^{90}$, demonstrando os inúmeros pontos de contato entre a sua evolução e a evolução dos direitos humanos fundamentais.

Assim é que, desde a Antiguidade, já havia a preocupação, por parte dos teóricos, com a necessidade de fixação de um conjunto de regras fundamentais que organizasse a vida em sociedade, dentro de uma estrutura incipiente que pode ser considerada como o antecedente histórico do Estado moderno ${ }^{91}$.

Regras essas limitadoras do poder dos governantes, impedindo-se o arbítrio, o mau uso do poder a eles conferido, submetendo o exercício do poder ao império da lei - nota fundamental identificadora da constituição como documento limitador do poder estatal ${ }^{92}$.

De tal época são as seguintes codificações, antecedentes históricos da constituição moderna: i) Código de Ur-Nammu, editado aproximadamente em 2100 a.C.; ii) Código de Hamurabi, rei da Mesopotâmia, famoso pela lógica do "olho por olho, dente por dente", o que na época representou uma grande revolução jurídica, pois impôs limites ao poder de

\footnotetext{
${ }^{88} \mathrm{~A}$ propósito, confira-se: i) CANOTILHO, José Joaquim Gomes. op. cit., p. 52; ii) BARROSO, Luís Roberto. Curso de direito constitucional contemporâneo, cit., p. 97; iii) SILVA, José Afonso da. op. cit., p. 43; iv) SARLET, Ingo Wolfgang; MARINONI, Luiz Guilherme; MITIDIERO, Daniel. Curso de direito constitucional, cit., p. 60-61; v) MORAES, Alexandre de. Direito constitucional, cit., p. 6-7; vi) OLIVEIRA, Márcio Luís de. A Constituição juridicamente adequada: transformações do constitucionalismo e atualização principiológica dos direitos, garantias e deveres fundamentais. Belo Horizonte: Arraes, 2013. p. 62-63; vii) SOUZA NETO, Cláudio Pereira de; SARMENTO, Daniel. Direito constitucional: teoria, história e métodos de trabalho. Belo Horizonte: Fórum, 2013. p. 50; viii) MOHNHAUPT, Heinz; GRIMM, Dieter. Constituição: história do conceito desde a antiguidade até nossos dias. Tradução Peter Naumann. Belo Horizonte: Tempus, 2012. p. 184-185.

${ }^{89}$ É nesse sentido que se manifesta Konrad Hesse ao falar em constituição como "ordem jurídica fundamental da comunidade". Confira-se em HESSE, Konrad. Constituição e direito constitucional. In: HESSE, Konrad. Temas fundamentais do direito constitucional. Tradução Carlos dos Santos Almeida, Gilmar Ferreira Mendes e Inocêncio Mártires Coelho. São Paulo: Saraiva, 2009. p. 3-8.

${ }^{90}$ Para um aprofundamento do tema relativo à história da constituição, confira a excelente obra: CERQUEIRA, Marcello. A Constituição na história: origem \& reforma. Rio de Janeiro: Revan, 1993.

${ }^{91}$ BARROSO, Luís Roberto. Curso de direito constitucional contemporâneo, cit., p. 25-27.

${ }^{92}$ Id. Ibid., p. 28-32.
} 
reparação de danos; iii) Torá, documento datado de aproximadamente 1250 a.C., organizador do povo de Israel.

Quanto aos teóricos da Antiguidade defensores da necessidade de se impor limites legais ao poder do soberano, destacam-se: i) Meng-tzu (Mêncio), seguidor de Confúcio e defensor da ideia fundamental da bondade da natureza humana (340 a.C.), retomada posteriormente pelos iluministas e inspiradora da ideia de contrato social, como fundamento teórico das primeiras constituições modernas; ii) Aristóteles, autor do primeiro ensaio sobre a necessidade do estabelecimento de normas para uma sociedade política, no "Ensaio sobre a Constituição de Atenas", datado entre 332 e 322 a.C., e o primeiro filósofo a utilizar a expressão "constituição", definindo-a como “distribuição de poderes num estado" $" 93$.

Não se pode olvidar, ademais, que Grécia e Roma foram duas formas de organização do Estado em que o poder era limitado pela lei, havendo uma separação entre as funções estatais, antecedente histórico do regime de separação das funções no Estado moderno ${ }^{94}$.

Já durante a Idade Média, há que se recordar a organização social do período, baseada no poder dos senhores feudais e na existência dos estamentos, ou seja, cada pessoa integrava um grupo pré-definido, inclusive, dotado de regime jurídico próprio, outorgado exatamente pelo senhor feudal.

Com o passar dos séculos, notadamente a partir do século XII, iniciou-se a formação dos Estados Nacionais, dotados de soberania, ou seja, de unidade de jurisdição e de poder, mediante a unificação de diversos feudos, iniciando-se a forma de governo das monarquias nacionais absolutistas, onde o monarca conferia direitos restritos aos súditos, por meio de instrumentos jurídicos como as cartas forais e, o mais famoso deles, a Magna Carta, outorgada pelo rei inglês João I (João sem-terra) em 1215 em favor dos barões ingleses ${ }^{95}$.

\footnotetext{
${ }^{93}$ Para maior aprofundamento sobre o assunto, confira-se: CASTILHO, Ricardo. Direitos humanos: processo histórico - evolução no mundo, direitos fundamentais: constitucionalismo contemporâneo. São Paulo: Saraiva, 2010. p. 23-25.

${ }^{94}$ Um quadro da estrutura de poder na Grécia e em Roma explicando como a expressão "constituição" era entendida em tais contextos é dado por MOHNHAUPT, Heinz; GRIMM, Dieter. op. cit., p. 19-31.

${ }^{95}$ Confira-se, a propósito: i) CASTILHO, Ricardo. op. cit., p. 27-38; ii) MOHNHAUPT, Heinz; GRIMM, Dieter. op. cit., p. 31-60.
} 
A partir deste momento histórico, a história das constituições se triparte, até culminar em três revoluções próprias, todas instituidoras do moderno Estado Constitucional de Direito, a saber: i) história da revolução inglesa; ii) história da revolução americana; iii) história da revolução francesa.

I) Em termos resumidos, a Inglaterra passa por um processo lento, seguro e gradual de transformação de um Estado feudal para um Estado monárquico (séc. X), primeiro absolutista, migrando aos poucos para a figura da Monarquia Constitucional (sécs. XIII a XVII).

Tal movimento se inicia com a outorga da Magna Carta em 1215, passa pela edição de documentos jurídicos de outorga de direitos fundamentais aos súditos como a Petition of Rights (1628) e o Habeas Corpus Act (1679), e culmina com a edição do Bill of Rights (1689), considerado a etapa final de consolidação do poder nas mãos do Parlamento inglês.

Não há um movimento revolucionário propriamente dito, não obstante ao longo daqueles séculos - notadamente durante o século XVII - tenha havido uma série de lutas internas entre o monarca e o parlamento, com avanços e retrocessos em termos de transferência paulatina, do poder, do monarca para o parlamento.

Ademais, trata-se da transferência de poder político do monarca para a elite econômica - nobreza e burguesia ascendente - sem participação direta da população, razão pela qual, como já vimos, esse modelo de Estado consolidado na Inglaterra é chamado de Estado Liberal. Essa transferência de poder gerará uma série de revoltas populares ao longo dos séculos XIX e início do XX (pós-revolução industrial), culminando na transformação do Estado Liberal em Estado Social, voltado à garantia do proletariado e positivador dos direitos humanos fundamentais sociais.

Tal movimento, ademais, não culmina na edição de uma carta constitucional formal, mas representa a evolução e consolidação de costumes e comportamentos políticos reiterados, editados pelos monarcas, e pelo parlamento, que vai conformando limites e o alcance desse modelo de Estado Liberal.

De qualquer sorte, ao final do processo (final do século XVII), tem-se um modelo de Estado Constitucional, fundado na common law e na primazia do parlamento, com a imposição clara de limites ao poder político e a garantia de direitos humanos fundamentais 
de liberdade aos súditos (as chamadas liberdades públicas, como direitos humanos fundamentais de primeira dimensão, verdadeiras vedações à atuação estatal) ${ }^{96}$.

É certo que o modelo constitucional inglês não foi inspirado em um modelo teórico filosófico, sendo fruto de longa e lenta evolução histórica.

Não obstante, sua consolidação em uma monarquia constitucional - o Poder Judiciário, historicamente, não tinha competência para analisar a constitucionalidade das leis editadas (apenas recentemente foi criado o Tribunal Constitucional inglês, e somente em razão da adoção de tratado firmado na União Europeia) - demonstra a influência do modelo teórico de John Locke, iluminista inglês, estudioso da realidade inglesa dos séculos XIV e XV, defensor do contratualismo como fundamento do Estado e de uma constituição fulcrada na separação de poderes notadamente entre o monarca e o parlamento ${ }^{97}$.

II) Já o constitucionalismo de matriz norte-americana é fruto de uma revolução calcada em um binômio: i) fático, resultante da excessiva exploração inglesa na tributação da colônia; ii) teórico, coincidente com o pensamento dos teóricos iluministas, principalmente John Locke, Barão de Montesquieu e Jean-Jacques Rousseau, que no mundo do Direito ficaram conhecidos como os introdutores do pensamento jusnaturalista.

Há que se recordar que o pensamento jusnaturalista tinha como pressuposto a existência de direitos humanos naturais, anteriores e superiores à própria formação do Estado, já que, no estado natural, o homem seria bom e dotado de direitos ilimitados, restringidos pelos governantes unicamente e na exata medida necessária à vida em sociedade ${ }^{98}$.

Corolário inarredável, limitador e conformador do poder dos governantes, foi a conclusão pela existência de limites imanentes e inerentes ao poder político no funcionamento estatal, e cujo instrumento jurídico veiculador é a constituição.

Tal pensamento se ajustou como uma luva aos interesses dos colonos norteamericanos, que não suportavam mais a exploração econômica pela metrópole inglesa,

\footnotetext{
${ }^{96}$ Para aprofundamento histórico do processo de formação do Estado Constitucional Liberal inglês, confirase: i) CASTILHO, Ricardo. op. cit., p. 39-48; ii) CERQUEIRA, Marcello. op,. cit., p. 18-24; iii) BARROSO, Luís Roberto. Curso de direito constitucional contemporâneo, cit., p. 32-36.

${ }^{97} \mathrm{Um}$ bom resumo dos principais pensamentos de John Locke é encontrado em: MORRIS, Clarence (Org.). Os grandes filósofos do direito. Tradução de Reinaldo Guarany. São Paulo: Martins Fontes, 2002. p. 130-155.

${ }^{98} \mathrm{Um}$ resumo do pensamento destes três expoentes do iluminismo é obtido em: MORRIS, Clarence (Org.). op. cit., p. 130-181 e 211-234.
} 
fazendo eclodir o levante em meados de 1770 que teve como pano de fundo a tributação sobre o chá.

Em poucas tintas, as treze colônias se reuniram inicialmente em uma assembleia chamada de "Congresso Continental”, e posteriormente em reuniões que evoluíram no período entre 1773 a 1787, culminando com a promulgação da constituição americana de 1787, ratificada pelos Estados-membros até 1789, posteriormente emendada para a inclusão do rol de direitos humanos fundamentais constitucionais em 1791 (Bill of Rights).

Apesar de ter havido uma série de disputas em torno dos ideais a nortearem o novo Estado norte-americano, prevaleceu o ideal mais próximo do pensamento iluministajusnaturalista, de verdadeira ruptura com as ordens políticas até então existentes, o que transformou os Estados Unidos da América na primeira nação republicana e federalista da história.

A preocupação com a separação e a harmonia entre as três funções clássicas de exercício do poder político estatal, com nítida origem teórica em Montesquieu, norteou a elaboração da sucinta constituição norte-americana, dotada de apenas sete artigos, sendo que os três primeiros dão a conformação exata dos Poderes Executivo, Legislativo e Judiciário.

O papel do Poder Judiciário como guardião e defensor da constituição se cristalizou por meio da célebre decisão proferida pelo então chief justice John Marshall no caso Marbury x Madison, proferida em 1803, na qual se reconheceu de forma expressa a competência do Poder Judiciário para a realização do controle difuso de constitucionalidade de leis e atos normativos editados pelos outros dois poderes da República. Modelo que inspirou a primeira constituição republicana do Brasil (1891), que nesse particular não seguiu a tradição constitucional europeia, mas, por influência de Rui Barbosa, a tradição norte-americana, repetida até os dias atuais.

Veja que, diversamente do constitucionalismo inglês, o norte-americano surgiu mediante revolução dos colonos que queriam se tornar independentes da metrópole, logo, de forma abrupta e turbulenta, contando desde o início com substrato teórico (iluministajusnaturalista), formador também de um Estado Constitucional Liberal, porém, com tripartição do poder político estatal, e dentro de um modelo republicano.

Ademais, tratou-se da prática de atos que levaram à formação de um Estado totalmente novo, até então inexistente, com a introdução de uma constituição também 
nova, logo, criadora do modelo de Estado norte-americano. Foi ato original de criação de Estado Constitucional de Direito ${ }^{99}$.

Por fim, trata-se de modelo instituidor de uma carta constitucional, aliás, da primeira constituição formal da história da humanidade, conforme entendimento pacífico entre os constitucionalistas ${ }^{100}$.

III) Por último, surge o movimento constitucionalista francês, fruto de uma revolução levada a cabo dentro de um Estado monárquico absolutista, no qual a burguesia ascendente era alijada do poder político, não obstante detivesse o poder econômico, ficando relegada ao chamado "terceiro Estado", dentro de um modelo então vigente no qual o poder era concentrado nos dois primeiros Estados, compostos pela nobreza e pelo clero.

Não obstante tanto norte-americanos como franceses tenham compartilhado a ideia de revolução como forma para se alcançar a mudança do modelo de Estado vigente, bem como o ideal teórico iluminista, há uma diferença fundamental entre os dois levantes instauradores de um modelo de Estado Constitucional de Direito Liberal: a revolução norte-americana fez surgir um Estado novo, enquanto que na França o que houve foi uma substituição de modelo de Estado, quando o povo, insatisfeito, derrubou o modelo até então vigente, absolutista, e em seu lugar instaurou um modelo galgado na limitação do poder estatal.

Nesse diapasão, é certo que a preocupação basilar do movimento revolucionário francês foi exatamente a instauração de um regime limitador do poder estatal, pela dupla via da separação das funções estatais e da codificação dos direitos humanos fundamentais (Declaração Universal dos Direitos do Homem e do Cidadão), a ponto de constar a seguinte disposição na Declaração Universal:

Art. $16^{\circ}$ A sociedade em que não esteja assegurada a garantia dos direitos nem estabelecida a separação dos poderes não tem Constituição.

\footnotetext{
${ }^{99}$ Para aprofundamento histórico do processo de formação do Estado Constitucional Liberal republicano norte-americano, confira-se: i) CASTILHO, Ricardo. op. cit., p. 51-62; ii) CERQUEIRA, Marcello. op,. cit., p. 33-53; iii) BARROSO, Luís Roberto. Curso de direito constitucional contemporâneo, cit., p. 37-44.

${ }^{100}$ É nesse exato sentido o escólio de Luís Roberto Barroso: “A primeira Constituição escrita do mundo moderno passou a ser o marco simbólico da conclusão da Revolução Americana em seu tríplice conteúdo: a) independência das colônias; b) superação do modelo monárquico; c) implantação de um governo constitucional, fundado na separação de Poderes, na igualdade e na supremacia da lei (rule of the law)." BARROSO, Luís Roberto. Curso de direito constitucional contemporâneo, cit., p. 39.
} 
Diversamente do movimento norte-americano, que privilegiou o sistema de separação de poderes como mecanismo de limitação do poder estatal, a ponto de a carta de declaração de direitos humanos individuais surgir apenas posteriormente, como emenda à constituição, o modelo francês deu primazia à declaração de direitos como mecanismo mais eficaz de limitação do poder estatal, a ponto de a Declaração Universal dos Direitos do Homem e do Cidadão ser o preâmbulo e fundamento da constituição francesa.

Outrossim, e diversamente das duas revoluções anteriormente analisadas, a revolução francesa teve grande preocupação com a legitimação popular do movimento, até mesmo porque contou com forte adesão dos desvalidos, utilizando-se de conceitos então recentemente elaborados como soberania $\operatorname{popular}^{101}$ e poder constituinte ${ }^{102}$, legitimadores da promulgação de uma constituição como documento fundante do novo modelo de Estado.

Durante todo o período histórico de evolução, a revolução francesa testou diversos formatos de Estado, de vertente monárquica ou republicana, passando mesmo pelo modelo imperial, demonstrando a força do povo e da soberania popular como motor de transformação do modelo estatal. Falo aqui de um período que vai de 1787 até o fim da primeira metade do século XIX, período no qual foram promulgadas nada menos do que oito cartas constitucionais francesas (três revolucionárias, três napoleônicas e duas no período de restauração). Desde a revolução até a atual e vigente constituição de 1958, republicana presidencial, foram editadas quatorze constituições na França, o que demonstra o tamanho da insatisfação acumulada com o Ancien Régime, bem como as diversas disputas internas pelo poder e as disparidades de teorias e entendimentos sobre como deveria ser formatado o novo Estado francês ${ }^{103}$.

\footnotetext{
${ }^{101} \mathrm{O}$ conceito de soberania popular surge com Jean-Jacques Rousseau, grande teórico iluminista cujas ideias foram muito utilizadas como substrato teórico da Revolução Francesa. Confira-se um resumo bem elaborado de suas ideias em: MORRIS, Clarence (Org.). op. cit., p. 211-234.

${ }^{102} \mathrm{O}$ conceito teórico de poder constituinte é inaugurado pelo Abade francês Sieyès, que o alça à condição de pressuposto imprescindível e suficiente à elaboração de uma nova constituição, fundante de um novo modelo de Estado, que na ocasião foi identificado junto ao terceiro Estado francês, onde se localizava a burguesia ávida pela obtenção do poder político na França. Para operacionalização do conceito, Sieyès identifica no terceiro Estado a presença da soberania popular, conceito elaborado por Rousseau e que tinha a vantagem de prescindir da presença de todos os súditos para a elaboração da carta constitucional. Bastava a eleição prévia de representantes, que seriam os responsáveis eleitos pelo povo para a sua elaboração. É o conceito inaugural de democracia representativa. Para maiores detalhes, confira-se: i) CANOTILHO, José Joaquim Gomes. op. cit., p. 65-84; ii) SOUZA NETO, Cláudio Pereira de; SARMENTO, Daniel. op. cit., p. 241-278; iii) BARROSO, Luís Roberto. Curso de direito constitucional contemporâneo, cit., p. 117-144.

${ }^{103}$ Para aprofundamento histórico do processo de formação do Estado Constitucional Liberal francês, confirase: i) CASTILHO, Ricardo. op. cit., p. 65-71; ii) CERQUEIRA, Marcello. op,. cit., p. 56-128; iii) BARROSO, Luís Roberto. Curso de direito constitucional contemporâneo, cit., p. 45-55.
} 
Apesar das diversidades teóricas e práticas existentes entre os três movimentos revolucionários, é fato que existem alguns pontos em comum, relevantes o suficiente para serem considerados como desencadeadores e instauradores do Estado Constitucional de Direito, de moldura liberal-burguesa, inaugurando, outrossim, o constitucionalismo tal como o conhecemos hoje na ciência jurídica.

Os três movimentos surgiram em decorrência de enormes transformações ocorridas ao longo dos séculos nos modelos sociais e econômicos até então vigentes, sendo que a diferença temporal entre a revolução inglesa (séc. XVII) e a norte-americana e francesa (séc. XVIII) decorre principalmente do fato de a burguesia, como nova classe social surgida com o advento do modo de produção capitalista, ter alcançado historicamente a posição de elite econômica primeiramente na Inglaterra.

Assim é que, nos três casos (Inglaterra, colônia norte-americana e França), o poder político estava concentrado nas mãos do monarca, que reinava de forma absoluta; a nobreza e o clero, até então detentores das terras, posição símbolo da riqueza na Idade Média, gozavam de uma série de privilégios, notadamente os privilégios econômicos advindos, agora, da cobrança escorchante de impostos sobre a classe burguesa, que com o tempo assumiu o posto de classe social mais poderosa economicamente.

Era uma questão de tempo até que a classe detentora do poder econômico almejasse o poder político; a atitude do monarca, da nobreza e do clero serviu de estopim e pretexto para a derrubada do regime até então vigente, com a instauração de novo modelo de Estado Soberano.

Como a burguesia obtinha sua riqueza do comércio - que quanto mais livre fosse maior seria a acumulação de riquezas -, evidentemente que o modelo a ser instaurado deveria primar pela liberdade de atuação, o que significava, por outro lado, que o Estado deveria ser contido em suas ações.

Tal necessidade, aliada ao arsenal iluminista-jusnaturalista, deu origem ao modelo constitucional moderno, no qual o poder político não é mais absoluto, mas limitado, e não mais exercido por uma única pessoa, mas com uma necessária separação das funções estatais, de modo que uma função limite e fiscalize o exercício da outra.

Além de limitado, há esferas nas quais o poder político não pode atuar notadamente nas esferas econômica e individual: aqui surge a necessidade de codificação de direitos humanos fundamentais, como garantias à pessoa humana contra eventual 
ingerência estatal (nesta etapa da evolução humana, falo das liberdades públicas, como direitos humanos fundamentais de primeira dimensão).

\title{
3.3. Conceito e evolução até nossos dias
}

Está pronto, assim, o conceito moderno de constituição, de matriz liberal-burguesa: instrumento jurídico de limitação do poder estatal, via organização das funções estatais e garantia de direitos humanos fundamentais.

Já o constitucionalismo, em sua acepção moderna, representa a teoria que busca a limitação do poder estatal com fins de garantia dos direitos humanos fundamentais.

Tal conceito vai ao encontro daqueles até hoje utilizados pela doutrina constitucionalista mais abalizada sobre o tema, a saber:

\begin{abstract}
Constitucionalismo é a teoria (ou ideologia) que ergue o princípio do governo limitado indispensável à garantia dos direitos em dimensão estruturante da organização político-social de uma comunidade. Neste sentido, o constitucionalismo moderno representará uma técnica específica de limitação do poder com fins garantísticos. O conceito de constitucionalismo transporta, assim, um claro juízo de valor. É, no fundo, uma teoria normativa da política, tal como a teoria da democracia ou a teoria do liberalismo ${ }^{104}$.

Constitucionalismo significa, em essência, limitação do poder e supremacia da lei (Estado de direito, rule of the law, Rechtsstaat) ${ }^{105}$.
\end{abstract}

Inevitáveis três conclusões do até aqui exposto: i) o surgimento do constitucionalismo e a codificação das primeiras constituições e dos direitos humanos fundamentais (neste ponto da história, apenas as liberdades públicas) são frutos de lutas pelo reconhecimento de dada categoria como sujeito de direitos (a burguesia); ii) o resultado de tais lutas pelo reconhecimento molda o formato dos emergentes Estados Nacionais - não é sem razão que o primeiro modelo de Estado Constitucional de Direito é o liberal-burguês; iii) a doutrina constitucionalista e dos direitos humanos fundamentais possuem a mesma origem teórica iluminista-jusnatural, bem como seus instrumentos constituição e declarações de direitos - se fundamentam e se justificam de forma mútua e recíproca, a tal ponto que um não consegue existir sem o outro. Ou seja, não há constituição sem a positivação e garantia dos direitos humanos fundamentais em seu

\footnotetext{
${ }^{104}$ CANOTILHO, José Joaquim Gomes. op. cit., p. 51.

${ }^{105}$ BARROSO, Luís Roberto. Curso de direito constitucional contemporâneo, cit., p. 27.
} 


\section{bojo, e os direitos humanos fundamentais necessariamente precisam estar positivados nas cartas constitucionais dos diversos Estados Nacionais ${ }^{106}$.}

Mas, a conclusão fulcral advém do maior legado deixado pelas três revoluções que esmagaram os alicerces dos Estados absolutistas e, em seu lugar, plantaram o moderno Estado de Direito: a inversão da premissa lógica para a elaboração de qualquer teoria política a ser desenvolvida, que até então considerava o "homem como o lobo do homem"107. Por esse prisma os direitos do homem seriam meras concessões e benevolências praticadas pelo soberano, cujo poder era absoluto por necessidade de se colocar ordem nas coisas. A inversão dessa premissa enxerga uma "natureza humana boa", com o homem livre no estado de natureza e, por decorrência, com a necessidade de um Estado em uma estrutura mínima e limitada, atuando dentro do extremamente necessário para garantir a vida em sociedade, e nada mais. Neste novo cenário os direitos do homem passam a ser garantias contra a atuação estatal ${ }^{108}$.

Tal inversão de perspectiva, também influenciada pelo cristianismo, conforme já demonstrado no capítulo 1 (ideia da "sacralização da pessoa"), manteve seu curso histórico, moldando o constitucionalismo, mas agora de forma uniforme novamente, em um movimento de universalização, de molde a que os demais países ocidentais também

\footnotetext{
${ }^{106}$ Tal constatação é trazida por J.J. Gomes Canotilho: “A própria constituição - incluída na estrutura básica - é encarada como um procedimento justo que incorpora as iguais liberdades políticas e garante a liberdade de pensamento. $\mathrm{O}$ modo como se combinam as liberdades num esquema coerente outra coisa não é senão uma teoria das liberdades básicas assente numa concepção política da pessoa e indispensável à justificação de um regime constitucional. Mais uma vez, as teorias dos direitos básicos são momentos fundamentais de uma teoria normativa da constituição incluída numa teoria do político. A constituição é, precisamente, entendida como um procedimento político justo que incorpora as iguais liberdades políticas e procura assegurar o seu justo valor de modo que os processos de decisão política sejam acessíveis a todos numa base aproximadamente igual. Neste sentido, a Constituição será também o estatuto comum de cidadãos iguais na medida em que incorpora e especifica as liberdades básicas”. CANOTILHO, José Joaquim Gomes. op. cit., p. 1405.

${ }^{107}$ Famosa expressão hobbesiana, utilizada em seus escritos justificadores do Estado Absoluto, como mal necessário à organização da vida em sociedade, em razão da premissa de que a natureza humana seria má.

${ }^{108}$ Quem capta com maestria tal fenômeno é Norberto Bobbio: "De modo geral, a afirmação de que o homem enquanto tal, fora e antes da formação de qualquer grupo social, tem direitos originários representa uma verdadeira reviravolta tanto na teoria quanto na prática políticas, reviravolta que merece ser brevemente comentada. A relação política - ou a relação entre governantes e governados, entre dominantes e dominados, entre príncipe e povo, entre soberano e súditos, entre Estado e cidadãos - é uma relação de poder que pode assumir três direções, conforme seja considerada como relação de poder recíproco, como poder do primeiro dos dois sujeitos sobre o segundo, ou como poder do segundo sobre o primeiro. Tradicionalmente, tanto no pensamento político clássico quanto naquele que predominou na Idade Média, a relação política foi considerada como uma relação desigual, na qual um dos dois sujeitos da relação está no alto enquanto o outro está embaixo; e na qual o que está no alto é o governante em relação ao governado (...). Mas tanto Locke quanto Kant são jusnaturalistas ou seja, ambos são pensadores que já haviam efetuado aquela inversão de perspectiva, para usar uma famosa expressão do próprio Kant, ainda que usada por ele num outro contexto, aquela "revolução copernicana" que faz com que a relação política seja considerada não mais ex parte principis, mas sim ex parte civium”. BOBBIO, Norberto. op. cit., p. 105-107.
} 
promulgassem suas respectivas constituições, dentro desse mesmo modelo formatado como fruto das experiências supratranscritas.

E a evolução histórica, conforme já largamente analisado no capítulo 2, se dá da seguinte forma: i) em razão da revolução industrial inglesa e surgimento da classe social do proletariado, altamente explorada pela burguesia, agora classe dominante econômica e politicamente, dá-se início a uma série de lutas pelo reconhecimento que culmina na formatação do Estado Constitucional Social de Direito, com a positivação dos direitos humanos fundamentais de segunda dimensão (direitos econômicos e sociais), cujas duas primeiras e emblemáticas cartas constitucionais são a mexicana, de 1917, e da República de Weimar, de 1919; trata-se de movimento que se estende durante o século XIX e primeira metade do século XX, cujo substrato teórico é retirado, notadamente, das correntes do materialismo histórico e da Teoria Crítica, em uma superação dos ideais iluministas; ii) já ao longo do século XX e dentro de um movimento constante de ampliação e universalização no reconhecimento dos sujeitos de direito, fruto de diversas lutas travadas, notadamente pelo direito à educação e ao sufrágio universal, ultrapassase a visão exclusiva individualista e se passa a uma abordagem também coletiva, fulcrada na solidariedade, dando origem ao modelo de Estado Constitucional Social e Democrático de Direito (também conhecido como Estado Democrático de Direito), bem como aos direitos humanos fundamentais de terceira dimensão, notadamente de índole coletiva (direito à autodeterminação dos povos, ao meio ambiente, ao sufrágio universal etc. $)^{109}$.

Veja que o movimento é de ampliação e aperfeiçoamento dos mecanismos garantidores da limitação do poder estatal e dos direitos humanos fundamentais, bem como de universalização de tal modelo para todo o mundo ocidental e, atualmente, para todo o universo, o que é evidenciado pela criação de um sistema internacional de proteção dos direitos humanos fundamentais, sempre atrelado à ideia de instituição de um modelo constitucional democrático em cada Estado Nacional.

A evolução do modelo constitucionalista já chegou a tal ponto que, atualmente, debatem-se os diversos conceitos e modelos de constituição ${ }^{110}$; como os mecanismos

\footnotetext{
${ }^{109}$ Para um apanhado desta evolução histórica do constitucionalismo até os nossos dias, confira-se: OLIVEIRA, Márcio Luís de. op. cit., p. 98-131.

${ }^{110}$ Entram aqui as diversas classificações de constituição, a partir dos critérios: i) formal - escritas e não escritas; ii) origem - promulgadas e outorgadas; iii) estabilidade do texto - rígidas, flexíveis e semirrígidas; iv) conteúdo - sintéticas e analíticas etc. Sobre o assunto, vide: i) BARROSO, Luís Roberto. Curso de direito constitucional contemporâneo, cit., p. 103-105; ii) SOUZA NETO, Cláudio Pereira de; SARMENTO, Daniel. op. cit., p. 51-65. Também as diversas definições de constituição, em seus aspectos histórico-político e jurídico (formal e material). O presente estudo se preocupa notadamente em analisar a constituição em seu aspecto jurídico.
} 
garantidores do Estado de Direito se relacionam e interagem com os mecanismos garantidores do Estado Social e do Estado Democrático ${ }^{111}$; e de que forma as disposições constitucionais devem ser interpretadas, inclusive, de molde a orientar a intepretação de toda a legislação infraconstitucional dos países ${ }^{112}$.

Ou seja, o direito constitucional e as respectivas cartas constitucionais passam a ser o centro do sistema normativo de cada Estado, possuindo elevada carga normativa, como mola propulsora a compelir e orientar a atividade estatal e da própria sociedade, exigindo a concretização dos princípios e regras gerais nela plasmados. Trata-se do inegável fenômeno da constitucionalização do Direito ${ }^{113}$.

Quanto ao Brasil, o caminho da evolução histórica de suas cartas constitucionais seguiu a tendência mundial, notadamente o caminho traçado por Portugal, sua antiga metrópole, cujo aparato jurídico sempre influenciou a evolução do direito em nosso país.

Interessante notar que a primeira constituição brasileira, de 1824, foi fruto da mesma revolução ocorrida em Portugal, em 1820, que deu origem à carta constitucional portuguesa de 1822: a revolução Liberal do Porto, que culminou com a instalação das chamadas "Cortes Constitucionais portuguesas", as quais contaram com a participação de deputados brasileiros.

Por seu turno, ambas possuem marcada influência da Constituição espanhola editada em 1812, conhecida como “Constituição de Cádiz”, todas elas instituidoras de uma Monarquia Constitucional.

\footnotetext{
${ }^{111}$ Confira-se, a propósito: i) CANOTILHO, José Joaquim Gomes. op. cit., p. 92-102; ii) BARROSO, Luís Roberto. Curso de direito constitucional contemporâneo, cit., p. 62-64 iii) SOUZA NETO, Cláudio Pereira de; SARMENTO, Daniel. op. cit., p. 78-86; iv) SAMPAIO, José Adércio Leite. op. cit., p. 61-75; v) HESSE, Konrad. Elementos de direito constitucional da República Federal da Alemanha, cit., p. 216-221.

${ }^{112}$ Para aprofundamento dos estudos sobre os diversos modelos de interpretação constitucional e como a constituição deve servir de "lupa" para a análise da legislação infraconstitucional, confira-se: i) CANOTILHO, José Joaquim Gomes. op. cit., p. 1195-1254; ii) HESSE, Konrad. Elementos de direito constitucional da República Federal da Alemanha, cit., p. 53-75; iii) BARROSO, Luís Roberto. Curso de direito constitucional contemporâneo, cit., p. 290-377; iv) SOUZA NETO, Cláudio Pereira de; SARMENTO, Daniel. op. cit., p. 391-463.

${ }^{113}$ Fenômeno muito bem sintetizado por Luís Roberto Barroso: "A ideia de constitucionalização do Direito aqui explorada está associada a um efeito expansivo das normas constitucionais, cujo conteúdo material e axiológico se irradia, com força normativa, para todo o sistema jurídico. Os valores, os fins públicos e os comportamentos contemplados nos princípios e regras da Constituição passam a condicionar a validade e o sentido de todas as normas do direito infraconstitucional. Como intuitivo, a constitucionalização repercute sobre a atuação dos três Poderes, inclusive e notadamente nas suas relações com os particulares. Porém, mais original ainda: repercute, também, nas relações entre particulares". BARROSO, Luís Roberto. Curso de direito constitucional contemporâneo, cit., p. 379.
} 
Influência revertida quando da promulgação da primeira constituição republicana, que ocorreu primeiramente no Brasil (1891) para, somente em 1911, ser o regime político adotado em Portugal.

De qualquer sorte, Brasil e Portugal passaram pelos modelos de Estado Monárquico Constitucional Liberal, Republicano Liberal, Republicano Social e, atualmente, Republicano Social Democrático, sendo que a atual carta brasileira (1988) guarda grande influência da carta portuguesa de 1976, ambas fruto de um processo de redemocratização.

Por outro lado, a influência mútua e recíproca entre as cartas portuguesas e espanholas também é patente, o que permite afirmar a existência de uma tradição constitucional ibérica já enraizada nos países integrantes da Península Ibérica e da América Latina ${ }^{114}$.

\subsection{A evolução teórica do constitucionalismo: de um documento político para um documento dotado de força normativa - de Ferdinand Lassalle a Konrad Hesse}

Voltando aos três momentos históricos fulcrais (evolução inglesa e revoluções norte-americana e francesa), é certo que, a partir de então (final do século XVIII), estava implantado o movimento constitucionalista, com seu instrumento jurídico garantista, que é a carta constitucional, como molde formatador do modelo de Estado a ser seguido em dada nação soberana.

Não obstante, o processo de juridicização das constituições ainda levou quase dois séculos para se completar.

\footnotetext{
${ }^{114} \mathrm{Um}$ resumo de tal evolução histórica, com as marcadas influências recíprocas, é dado por Marcello Cerqueira, na seguinte passagem: "O constitucionalismo nasceu simultaneamente no Brasil e em Portugal a partir da Revolução do Porto, em 1820, que resultou a reunião das Cortes Constitucionais portuguesas, inclusive com a malograda participação de deputados "eleitos" pelas províncias brasileiras. A Constituição de 1822 foi votada por portugueses e brasileiros (...) e se pretendia valer para o Reino Unido de Portugal e Algarve, mas, mesmo antes de sua aprovação (23 de setembro), D. Pedro I já proclamara a Independência a 7 de setembro. A Carta Constitucional portuguesa de 1826 foi copiada da nossa Carta de 1824 e imposta pelo mesmo D. Pedro I no Brasil e IV de Portugal, e com todos os percalços, as duas Cartas teriam vigência conjunta por meio século, o que levou Jorge Miranda a dizer que as duas leis poderiam se constituir numa família ou subfamília constitucional luso-brasileira. Também, como se verá em sede própria, a primeira Constituição republicana brasileira iria exercer marcada influência sobre a também primeira Constituição republicana portuguesa de 1911. (...) Jorge Miranda salienta o paralelismo da evolução políticoconstitucional de Portugal e da Espanha, mais perceptível a partir do começo do século XIX. A primeira Constituição portuguesa tem por fonte a Constituição de Cádiz e cai em 1823, logo que na Espanha, Fernando VII é restabelecido como rei absoluto. (A Constituição de Cádiz, ainda que efemeramente, entrou em vigor no Brasil e D. João também cogitou de sua adoção em Portugal).”. CERQUEIRA, Marcello. op,. cit., p. 130.
} 
Isso porque, não obstante a doutrina iluminista enxergasse na constituição o documento fundante do Estado, organizador de sua vida política, ela ainda era vista como uma carta fora do mundo jurídico, logo, sem poder normativo, ou seja, a constituição era entendida como um documento narrativo da realidade do poder político da nação e, por isso mesmo, deveria necessariamente refletir a realidade dos fatores reais de poder existentes no momento de sua feitura.

Não detinha poder transformador, não possuindo força, portanto, para modificar a realidade política da nação, não vinculando os governantes.

Tal pensamento teórico, inicial do movimento constitucionalista, deu origem à chamada "constituição político-histórica", e assim desenvolveu seu raciocínio: a constituição era resultado da realidade do poder político de dada nação em dado período histórico, por isso não possuía natureza jurídica, mas sim política e histórica. Já o seu formato escrito, como documento de natureza jurídica (carta constitucional), não passaria de uma folha de papel sem qualquer efeito vinculante, caso não refletisse a exata distribuição do poder político do Estado.

Ou seja, no século XIX, a teoria constitucionalista entendia a constituição como resultado da realidade política, e não como um documento jurídico. Quando este existia, somente irradiaria efeitos jurídicos caso a formatação positivada guardasse correlação intrínseca com a realidade político-social da época, ficando o aspecto jurídico completamente subjugado e dependente do aspecto político-social.

O maior expoente teórico dessa vertente inicial constitucionalista foi Ferdinand Lassalle ${ }^{115}$, que em sua obra clássica “A Essência da Constituição” assim separou e definiu as constituições real (política) e escrita (jurídica):

Quando podemos dizer que uma constituição escrita é boa e duradoura?

A resposta é clara e parte logicamente de quanto temos exposto: Quando essa constituição escrita corresponder à constituição real e tiver suas razões nos fatores do poder que regem o país.

Onde a constituição escrita não corresponder à real, irrompe inevitavelmente um conflito que é impossível evitar e no qual, mais dia menos dia, a constituição escrita, a folha de papel, sucumbirá necessariamente, perante a constituição real, a das verdadeiras forças vitais do país.

(...)

\footnotetext{
${ }^{115}$ Não obstante se trate de uma visão atualmente ultrapassada e de fácil refutação, é importante ter em mente que, em termos históricos, tal visão inaugural representou grande evolução no pensamento jurídico, pois, inaugurou a era das Cartas Constitucionais, com todos os desdobramentos evolutivos alcançados ao longo dos últimos dois séculos.
} 
Os problemas constitucionais não são problemas de direito, mas do poder; a verdadeira Constituição de um país somente tem por base os fatores reais e efetivos do poder que naquele país vigem e as constituições escritas não têm valor nem são duráveis a não ser que exprimam fielmente os fatores do poder que imperam na realidade social; eis aí os critérios fundamentais que devemos sempre lembrar ${ }^{116}$.

Trata-se de uma visão inegavelmente pessimista do Direito, entendido como mero instrumento legitimador e garantidor do status quo político de dada nação. Visão compartilhada também por Karl Marx, de quem Lassalle é contemporâneo.

Sucede que tal falta de poder vinculante pela constituição, como documento despido de força normativa, é conclusão paulatinamente atacada e rechaçada pelos teóricos do direito, e que dará origem, na primeira metade do século $\mathrm{XX}$, a uma nova teoria do Direito: o positivismo jurídico.

Assim é que, em flagrante oposição a tais ideais, e transitando em um terreno radicalmente oposto, surge na primeira metade do século $\mathrm{XX}$ a teoria do positivismo jurídico, cujo maior expoente é Hans Kelsen, cuja teoria coloca a constituição como ápice do ordenamento jurídico de dada nação.

Ou seja, a constituição não é mero documento histórico-político, mas é alçado à posição de Lei Fundamental do país, como fundamento de validade de todo o ordenamento jurídico.

E mais. É um documento absolutamente desvencilhado da realidade históricopolítico-social do país, passando a ter validade própria a partir do momento em que inaugura uma nova ordem jurídica estatal.

Para tanto, o próprio direito é alçado à posição de ciência pura, desvencilhada de outros ramos do conhecimento, constituindo um sistema fechado e autossuficiente (sistema autopoiético); o sistema jurídico é celebrado como triunfo da razão humana, capaz de elaborar um sistema normativo completo, perfeito e acabado, sem lacunas ou contradições.

Veja que tal inversão absoluta de perspectiva faz com que o aspecto político-socialhistórico fique subjugado ao aspecto jurídico-normativo da constituição, exatamente o

\footnotetext{
${ }^{116}$ LASSALLE, Ferdinand. A essência da Constituição. Prefácio e organização Aurélio Wander Bastos. 9. ed. Rio de Janeiro: Freitas Bastos, 2014. p. 39 e 45.
} 
oposto do até então defendido pelos constitucionalistas clássicos, capitaneados por Lassalle $^{117}$.

Para os positivistas, a constituição é o ápice do ordenamento jurídico de uma nação e deve ser respeitada na forma como produzida, pois, embasada na "norma fundamental"; o corte metodológico da ciência do direito é feito exatamente na junção entre o direito e outras ciências humanas (política, sociologia, moral, filosofia etc.), alijando-as da abordagem científica, o que culminou, como é de conhecimento público e notório e já abordado no capítulo 2, com os horrores dos regimes nazista e fascista e a eclosão da segunda guerra mundial, de triste memória, o que evidencia a insuficiência da abordagem realizada por tal escola teórica.

Não obstante, o positivismo jurídico legou duas contribuições fulcrais ${ }^{118}$ para a evolução da teoria da constituição: i) a ideia de supremacia das normas constitucionais sobre as demais normas do ordenamento jurídico estatal ${ }^{119}$, com o seu intrínseco controle de constitucionalidade das leis e atos normativos; ii) a noção de unidade da constituição ${ }^{120}$,

${ }^{117}$ Confira-se, a propósito, elucidativa passagem de Hans Kelsen contida em sua obra "Teoria Pura do Direito": "Se por Constituição de uma comunidade se entende a norma ou as normas que determinam como, isto é, por que órgãos e através de que processos - através de uma criação consciente do Direito, especialmente o processo legislativo, ou através do costume - devem ser produzidas as normas gerais da ordem jurídica que constitui a comunidade, a norma fundamental é aquela norma que é pressuposta quando o costume, através do qual a Constituição surgiu, ou quando o ato constituinte (produtor da Constituição) posto conscientemente por determinados indivíduos são objetivamente interpretados como fatos produtores de normas; quando - no último caso - o indivíduo ou a assembleia de indivíduos que instituíram a Constituição sobre a qual a ordem jurídica assenta são considerados como autoridade legislativa. Neste sentido, a norma fundamental é a instauração do fato fundamental da criação jurídica e pode, nestes termos, ser designada como constituição no sentido lógico-jurídico, para a distinguir da Constituição em sentido jurídico-positivo. Ela é o ponto de partida de um processo: do processo da criação do Direito Positivo. Ela própria não é uma norma posta, posta pelo costume ou pelo ato de um órgão jurídico, não é uma norma positiva, mas uma norma pressuposta, na medida em que a instância constituinte é considerada como a mais elevada autoridade e por isso não pode ser havida como recebendo o poder constituinte através de uma outra norma, posta por uma autoridade superior". KELSEN, Hans. Teoria pura do direito. Tradução João Baptista Machado. 6. ed., 3 tir. São Paulo: Martins Fontes, 1999. p. 221-222.

${ }^{118}$ Tais contribuições são mantidas e salientadas pelos pós-positivistas (e pelos neoconstitucionalistas), conforme trazido de forma emblemática nas seguintes passagens do artigo Constituição e direito constitucional, cit., de Konrad Hesse: i) supremacia da constituição, p. 8-9; ii) unidade da constituição, p. 9-11.

119“'O poder constituinte cria ou refunda o Estado, por meio de uma Constituição. Com a promulgação da Constituição, a soberania popular se converte em supremacia constitucional. Do ponto de vista jurídico, este é o principal traço distintivo da Constituição: sua posição hierárquica superior às demais normas do sistema. A Constituição é dotada de supremacia e prevalece sobre o processo político majoritário - isto é, sobre a vontade do poder constituído e sobre as leis em geral - porque fruto de uma manifestação especial da vontade popular, em uma conjuntura própria, em um momento constitucional (v. supra). A supremacia da Constituição é um dos pilares do modelo constitucional contemporâneo, que se tornou dominante em relação ao modelo de supremacia do Parlamento, residualmente praticado em alguns Estados democráticos, como o Reino Unido e a Nova Zelândia.” BARROSO, Luís Roberto. Curso de direito constitucional contemporâneo, cit., p. 323.

120“'Pertence a isso, em primeiro lugar, o princípio da unidade da Constituição. A conexão e a interdependência dos elementos individuais da Constituição (supra, número de margem 20) fundamentam a necessidade de olhar nunca somente a norma individual, senão sempre também a conexão total na qual ela 
que deve ser entendida como um todo coeso e orgânico, sem contradições internas, logo, não havendo que se falar em conflito interno (antinomia) entre normas jurídicas constitucionais.

Desses dois movimentos teóricos podem ser extraídas duas conclusões essenciais, fundamentadoras do surgimento de um terceiro movimento constitucionalista, atualmente predominante: i) a corrente político-histórica da constituição, não obstante tivesse concluído de forma louvável que a carta constitucional de uma nação deveria levar em consideração os fatores reais de poder vigentes quando de sua elaboração, teve como grande falha a conclusão simplista e derrotista de que o instrumento jurídico deveria ficar submetido à realidade fática, sob pena de inescapável ineficácia; ii) o positivismo jurídico, ao revés, por alijar das discussões atinentes à elaboração da carta constitucional a realidade sócio-política da nação na época de sua elaboração (caráter "neutro" do direito), deixou de lançar o necessário olhar crítico às deficiências, injustiças e desequilíbrios reinantes, o que acaba fazendo com que o direito sirva de instrumento jurídico legitimador e mantenedor das forças políticas reinantes.

A atual linha teórica do direito enquanto ciência - e do constitucionalismo -, na verdade, procurou fazer uma junção dos dois olhares anteriores ${ }^{121}$, na tentativa de suprir as deficiências e omissões de cada corrente teórica: trata-se do pós-positivismo ${ }^{122}$ e da sua

deve ser colocada; todas as normas constitucionais devem ser interpretadas de tal modo que contradições com outras normas constitucionais sejam evitadas. Somente uma tal resolução do problema corresponde a esse princípio, que se mantém em consonância com as decisões fundamentais da Constituição e se preserva da restrição unilateral a aspectos parciais". HESSE, Konrad. Elementos de direito constitucional da República Federal da Alemanha, cit., p. 65.

${ }^{121}$ Neste exato sentido, emblemáticas são as palavras de Luís Roberto Barroso: “O pós-positivismo se apresenta, em certo sentido, como uma terceira via entre as concepções positivista e jusnaturalista: não trata com desimportância as demandas do Direito por clareza, certeza e objetividade, mas não o concebe desconectado de uma filosofia moral e de uma filosofia política. Contesta, assim, o postulado positivista de separação entre Direito, moral e política, não para negar a especificidade do objeto de cada um desses domínios, mas para reconhecer a impossibilidade de tratá-los como espaços totalmente segmentados, que não se influenciam mutuamente. Se é inegável a articulação complementar entre eles, a tese da separação, que é central ao positivismo e que dominou o pensamento jurídico por muitas décadas, rende tributo a uma hipocrisia. A doutrina pós-positivista se inspira na revalorização da razão prática, na teoria da justiça e na legitimação democrática. Nesse contexto, busca ir além da legalidade estrita, mas não despreza o direito posto; procura empreender uma leitura moral da Constituição e das leis, mas sem recorrer a categorias metafísicas. No conjunto de ideias ricas e heterogêneas que procuram abrigo nesse paradigma em construção, incluem-se a reentronização dos valores na interpretação jurídica, com o reconhecimento de normatividade aos princípios e de sua diferença qualitativa em relação às regras; a reabilitação da razão prática e da argumentação jurídica; a formação de uma nova hermenêutica; e o desenvolvimento de uma teoria dos direitos fundamentais edificada sobre a dignidade da pessoa humana. Nesse ambiente, promovese uma reaproximação entre o Direito e a ética." BARROSO, Luís Roberto. Curso de direito constitucional contemporâneo, cit., p. 270-272.

${ }^{122}$ A relação entre pós-positivismo e neoconstitucionalismo se dá dentro da noção de gênero e espécie: o póspositivismo é uma teoria do direito como ciência, e o neoconstitucionalismo é a teoria pós-positivista inserida no direito constitucional. 
vertente constitucionalista do neoconstitucionalismo ${ }^{123}$, cuja corrente mais conhecida e celebrada foi inaugurada pelo jurista alemão Konrad Hesse, consagradamente conhecida como a "força normativa da Constituição".

Os contornos de tal modelo, em nítida contraposição ao modelo até então reinante proposto por Ferdinand Lassalle, é dado por Konrad Hesse em sua obra basilar intitulada “A Força Normativa da Constituição”, por meio de respostas às seguintes indagações por ele formuladas no início do texto:

Existiria, ao lado do poder determinante das relações fáticas, expressas pelas forças políticas e sociais, também uma força determinante do Direito Constitucional? Qual o fundamento e o alcance dessa força do Direito Constitucional? Não seria essa força uma ficção necessária para o constitucionalista, que tenta criar a suposição de que o direito domina a vida do Estado, quando, na realidade, outras forças mostram-se determinantes ${ }^{124}$ ?

E o método para se chegar a tais respostas é claramente indicado em seguida:

Uma tentativa de resposta deve ter como ponto de partida o condicionamento recíproco existente entre a Constituição jurídica e a realidade político-social (1.). Devem ser considerados, nesse contexto, os limites e as possibilidades da atuação da Constituição jurídica (2.). Finalmente, hão de ser investigados os pressupostos de eficácia da Constituição (3. $)^{125}$.

Surgem, aqui, de maneira nítida, os dois pilares e maiores contribuições da teoria neoconstitucionalista para o estudo e desenvolvimento do direito constitucional como ciência: i) a análise conjunta dos aspectos histórico-político-social e jurídico das constituições, ou seja, a mescla entre as duas teorias jurídicas anteriores (historicismo constitucional e positivismo jurídico), que até então disputavam a primazia da explicação do fenômeno constitucional; ii) um enfoque da constituição fulcrado notadamente em sua eficácia, em seu poder normativo transformador (é o que Hesse chama de "concreção").

\footnotetext{
${ }^{123}$ Que fique claro desde já que o neoconstitucionalismo não é uma teoria dotada de premissas e metodologia únicas: existem diversas correntes integrantes do neoconstitucionalismo, que aqui é entendido e desenvolvido dentro de uma lógica de superação dos modelos constitucionais anteriores, tendo como pilar principal a "força normativa da constituição". Tal realidade restou muito bem captada por Daniel Sarmento: "Neste quadro, não é tarefa singela definir o neoconstitucionalismo, talvez porque, como já revela o bem escolhido título da obra organizada por Carbonell, não exista um único neoconstitucionalismo, que corresponda a uma concepção teórica clara e coesa, mas diversas visões sobre o fenômeno jurídico na contemporaneidade, que guardam entre si alguns denominadores comuns relevantes, o que justifica que sejam agrupadas sob um mesmo rótulo, mas compromete a possibilidade de uma conceituação mais precisa". SARMENTO, Daniel. Por um constitucionalismo inclusivo: história constitucional brasileira, teoria da Constituição e direitos fundamentais. Rio de Janeiro: Lumen Juris, 2010. p. 235-236.

${ }^{124} \mathrm{HESSE}$, Konrad. A força normativa da Constituição. Tradução de Gilmar Ferreira Mendes. Porto Alegre: Sergio Antonio Fabris, 1991. p. 11-12.

${ }^{125}$ Id. Ibid., p. 13.
} 
Em arremate, conclui Hesse que, da correlação entre constituição histórica e constituição jurídica, uma imbricando e influenciando a outra, bem como respeitando seus respectivos limites e possibilidades, chega-se a uma constituição como norma jurídica dotada de força vinculante e transformadora da realidade social, duradoura no tempo e formatadora do modelo de Estado vigente em dada sociedade, de tal modo que os próprios atores e fatores políticos reinantes na sociedade queiram de forma perene sua continuidade (fenômeno chamado de "vontade de constituição") ${ }^{126}$.

A missão do Direito Constitucional, por seu turno, é definida por Hesse com base na busca da máxima efetividade possível das normas constitucionais, sendo que, para tanto, deve ser assumida uma visão crítica, consentânea com a realidade social da época, de modo a evitar o surgimento de ilusões e de promessas irrealizáveis ${ }^{127}$.

De enorme interesse teórico e prático são os requisitos apresentados por Hesse como imprescindíveis ao êxito na empreitada da construção de um modelo constitucional, dotado de grande força normativa e que se perpetue no tempo: i) conteúdo constitucional consentâneo com a realidade social do tempo de sua elaboração; ii) caráter enxuto; iii) incorporação de parte da estrutura contrária à reinante no período de elaboração, evitandose o modelo de estrutura unilateral ${ }^{128}$.

\footnotetext{
${ }^{126}$ Tais são suas palavras conclusivas: "Em síntese, pode-se afirmar: a Constituição jurídica está condicionada pela realidade histórica. Ela não pode ser separada da realidade concreta de seu tempo. A pretensão de eficácia da Constituição somente pode ser realizada se se levar em conta essa realidade. A Constituição jurídica não configura apenas a expressão de uma dada realidade. Graças ao elemento normativo, ela ordena e conforma a realidade política e social. As possibilidades, mas também os limites da força normativa da Constituição resultam da correlação entre ser (Sein) e dever ser (Sollen). A Constituição jurídica logra conferir forma e modificação à realidade. Ela logra despertar "a força que reside na natureza das coisas", tornando-a ativa. Ela própria converte-se em força ativa que influi e determina a realidade política e social. Essa força impõe-se de forma tanto mais efetiva quanto mais ampla for a convicção sobre a inviolabilidade da Constituição, quanto mais forte mostrar-se essa convicção entre os principais responsáveis pela vida constitucional. Portanto, a intensidade da força normativa da Constituição apresentase, em primeiro plano, como uma questão de vontade normativa, de vontade de Constituição (Wille zur Verfassung)". HESSE, Konrad. A força normativa da Constituição, cit., p. 24.

127“"Em outros termos, o Direito Constitucional deve explicitar as condições sob as quais as normas constitucionais podem adquirir a maior eficácia possível, propiciando, assim, o desenvolvimento da dogmática e da interpretação constitucional. Portanto, compete ao Direito Constitucional realçar, despertar e preservar a vontade de Constituição (Wille zur Verfassung), que, indubitavelmente, constitui a maior garantia de sua força normativa. Essa orientação torna imperiosa a assunção de uma visão crítica pelo Direito Constitucional, pois nada seria mais perigoso do que permitir o surgimento de ilusões sobre questões fundamentais para a vida do Estado". Id. Ibid., p. 27.

128“Quanto mais o conteúdo de uma Constituição lograr corresponder à natureza singular do presente, tanto mais seguro há de ser o desenvolvimento de sua força normativa. Tal como acentuado, constitui requisito essencial da força normativa da Constituição que ela leve em conta não só os elementos sociais, políticos e econômicos dominantes, mas também que, principalmente, incorpore o estado espiritual (geistige Situation) de seu tempo. Isso lhe há de assegurar, enquanto ordem adequada e justa, o apoio e a defesa da consciência geral. Afigura-se, igualmente, indispensável que a Constituição mostre-se em condições de adaptar-se a uma eventual mudança dessas condicionantes. Abstraídas as disposições de índole técnico-organizatória,
} 
O específico requisito do caráter enxuto de que as constituições devem se revestir, para que possam ter a flexibilidade suficiente para se adaptarem às alterações da realidade sócio-política da nação, bem explica grave problema de nossa carta constitucional vigente (1988), a qual, por ser demasiadamente extensa e pormenorizada, vem sofrendo uma série de modificações pela via das emendas constitucionais (83 em um período de 25 anos, ou seja, mais de três alterações por ano), desfigurando sua unidade normativa, com sérios prejuízos à sua força vinculante.

Ademais, uma carta constitucional extensa, cheia de objetivos e imposições às atividades estatais, acaba por dificultar e muito a tarefa de concreção de tais misteres, com a consequente perda de confiança na força transformadora da constituição, preocupação fulcral na obra de Konrad Hesse, a ponto de seu modelo de constitucionalismo ser chamado de "teoria concretista"129.

Classificação exata, já que, segundo afirmado pelo próprio jurista alemão, “interpretação constitucional é concretização"130. (grifado)

Com o neoconstitucionalismo, desloca-se a noção tão difundida na Europa da supremacia do binômio lei-parlamento no estabelecimento da moldura do Estado para o modelo norte-americano, que desde o seu início foi calcado na noção de supremacia da constituição, conferindo ao Poder Judiciário a tarefa de exercer o controle de constitucionalidade de leis e atos normativos ${ }^{131}$. As normas constitucionais passam a ser

ela deve limitar-se, se possível, ao estabelecimento de alguns poucos princípios fundamentais, cujo conteúdo específico, ainda que apresente características novas em virtude das céleres mudanças na realidade sócio-política, mostre-se em condições de ser desenvolvido. A "constitucionalização" de interesses momentâneos ou particulares exige, em contrapartida, uma constante revisão constitucional, com a inevitável desvalorização da força normativa da Constituição. Finalmente, a Constituição não deve assentar-se numa estrutura unilateral, se quiser preservar a sua força normativa num mundo em processo de permanente mudança político-social. Se pretende preservar a força normativa dos seus princípios fundamentais, deve ela incorporar, mediante meticulosa ponderação, parte da estrutura contrária". HESSE, Konrad. A força normativa da Constituição, cit., p. 20-21.

${ }^{129}$ SOUZA NETO, Cláudio Pereira de; SARMENTO, Daniel. op. cit., p. 192-194.

${ }^{130}$ HESSE, Konrad. Elementos de direito constitucional da República Federal da Alemanha, cit., p. 61. Confira-se, do mesmo autor, o artigo A interpretação constitucional. In: HESSE, Konrad. Temas fundamentais do direito constitucional. Tradução Carlos dos Santos Almeida, Gilmar Ferreira Mendes e Inocêncio Mártires Coelho. São Paulo: Saraiva; 2009. p. 108-116. Também J.J. Gomes Canotilho é adepto de tal corrente teórica: CANOTILHO, José Joaquim Gomes. op. cit., p. 1222.

${ }^{131}$ Nesse diapasão, confiram-se os ensinamentos de Luís Roberto Barroso: "Uma das grandes mudanças de paradigma ocorridas ao longo do século XX foi a atribuição à norma constitucional do status de norma jurídica. Superou-se, assim, o modelo adotado na Europa até meados do século passado, no qual a Constituição era vista como um documento essencialmente político, um convite à atuação dos Poderes Públicos. Vigoravam a centralidade da lei e a supremacia do Parlamento, cujos atos eram insuscetíveis de controle judicial. Somente após a Segunda Guerra Mundial é que veio a se difundir - e, eventualmente, a prevalecer - o modelo americano de constitucionalismo, fundado na força normativa da Constituição, documento dotado de supremacia e protegido por mecanismos de controle de constitucionalidade. Desse 
entendidas como normas jurídicas, irradiadoras de efeitos jurídicos de forma imediata, cuja inobservância é passível de controle jurisdicional. Também os governantes encontram-se previamente limitados pela constituição no desempenho de suas tarefas, inclusive, na atividade legislativa ordinária ${ }^{132}$.

Já a recepção do modelo pós-positivista no Brasil dentro do Direito Constitucional, pela via do neoconstitucionalismo, é fenômeno recente, que se iniciou somente após a promulgação da vigente constituição de 1988, na qual foram assegurados mecanismos jurídicos de força normativa da constituição, tais como: i) a aplicabilidade imediata das normas constitucionais veiculadoras de direitos humanos fundamentais (art. $5^{\mathrm{o}}, \S 1^{\mathrm{o}}$ ); ii) a instituição de um rol de cláusulas pétreas, imodificáveis pelo poder constituinte derivado (art. $\left.60, \S 4^{\circ}\right)$; iii) o estabelecimento de um verdadeiro "bloco de constitucionalidade"133 para efeitos de parâmetro de controle da legislação infraconstitucional (por exemplo, art. $5^{\mathrm{o}}, \S \S \mathrm{s} 2^{\mathrm{o}}$ e $\left.3^{\circ}\right)$.

No tocante à aplicabilidade imediata das normas constitucionais veiculadoras de direitos humanos fundamentais ${ }^{134}$, confira-se o inteiro teor do aludido dispositivo

reconhecimento de caráter jurídico às normas constitucionais resultam consequências especialmente relevantes, dentre as quais se podem destacar: a) a Constituição tem aplicabilidade direta e imediata às situações que contempla, inclusive e notadamente as referentes à proteção e promoção dos direitos fundamentais. Isso significa que as normas constitucionais passam a ter um papel decisivo na postulação de direitos e na fundamentação de decisões judiciais; b) a Constituição funciona como parâmetro de validade de todas as demais normas jurídicas do sistema, que não deverão ser aplicadas quando forem com ela incompatíveis. A maior parte das democracias ocidentais possui supremas cortes ou tribunais constitucionais que exercem o poder de declarar leis e atos normativos inconstitucionais; c) os valores e fins previstos na Constituição devem orientar o intérprete e o aplicador do Direito no momento de determinar o sentido e o alcance de todas as normas jurídicas infraconstitucionais, pautando a argumentação jurídica a ser desenvolvida". BARROSO, Luís Roberto. Curso de direito constitucional contemporâneo, cit., p. 219-220.

${ }^{132}$ Tal limitação da própria atividade parlamentar, evitando que a maioria parlamentar imponha sua visão política sobre toda a coletividade, foi muito bem observada e explicada por CANOTILHO, José Joaquim Gomes. op. cit., p. 245-248.

${ }^{133}$ Para aprofundamento da questão atinente ao "bloco de constitucionalidade", que possibilitou o alargamento da força normativa da constituição para efeitos de controle da legislação infraconstitucional, confira-se: Id. Ibid., p. 919-929.

${ }^{134}$ Não pode haver dúvidas no sentido da plena aplicabilidade do disposto pelo artigo $5^{\circ}$, $\S 1^{\circ}$, da $\mathrm{CF} / 88$ aos direitos humanos fundamentais sociais, conforme escólio de Ingo Wolfgang Sarlet: "Ponto de partida da nossa análise será, aqui, também a constatação de que mesmo os direitos fundamentais a prestações são inequivocamente autênticos direitos fundamentais, constituindo (justamente em razão disto) direito imediatamente aplicável, nos termos do disposto no art. $5^{\circ}, \S 1^{\circ}$, de nossa Constituição. A exemplo das demais normas constitucionais e independentemente de sua forma de positivação, os direitos fundamentais prestacionais, por menor que seja sua densidade normativa ao nível da Constituição, sempre estarão aptos a gerar um mínimo de efeitos jurídicos, sendo, na medida desta aptidão, diretamente aplicáveis, aplicando-selhes (com muito mais razão) a regra geral, já referida, no sentido de que inexiste norma constitucional destituída de eficácia e aplicabilidade." SARLET, Ingo Wolfgang. A eficácia dos direitos fundamentais, cit., p. 297. 
constitucional: "§ $1^{\circ}$ - As normas definidoras dos direitos e garantias fundamentais têm aplicação imediata".

Ora, que as normas constitucionais são normas jurídicas e, portanto, irradiam desde a sua promulgação efeitos jurídicos, é algo sobre o que não mais se discute ${ }^{135}$.

Em assim sendo, não há outra interpretação possível senão a de que tal dispositivo constitucional tem por escopo impor um grau mais elevado de vinculação, por parte do Estado, no respeito, garantia e implementação dos direitos humanos fundamentais, alçando tais direitos ao patamar de objetivo fundamental da República. Trata-se de verdadeiro norte balizador das atividades estatais, de um reforço eficacial em prol das normas de tal jaez ${ }^{136}$.

Já no concernente à inserção dos direitos humanos fundamentais - inclusive sociais $^{137}$ - no rol de temas insuscetíveis de mutação constitucional (as chamadas “cláusulas pétreas”), confira-se o prescrito pelo artigo $60, \S 4^{\circ}, \mathrm{IV}$, da Constituição:

${ }^{135}$ Confira-se, a propósito: i) BARROSO, Luís Roberto. O direito constitucional e a efetividade de suas normas. 8. ed. Rio de Janeiro: Renovar, 2006. p. 102; ii) MELLO, Celso Antônio Bandeira de. op. cit., p. 12.

${ }^{136}$ Neste exato sentido, confira-se o escólio de Ingo Wolfgang Sarlet: "Levando-se em conta esta distinção, somos levados a crer que a melhor exegese da norma contida no art. $5^{\circ}, \S 1^{\circ}$, de nossa Constituição é a que parte da premissa de que se trata de norma de cunho inequivocamente principiológico, considerando-a, portanto, uma espécie de mandado de otimização (ou maximização), isto é, estabelecendo aos órgãos estatais a tarefa de reconhecerem a maior eficácia possível aos direitos fundamentais, entendimento este sustentado, entre outros, no direito comparado, por Gomes Canotilho e compartilhado, entre nós, por Flávia Piovesan. (...) Assim, para além da aplicabilidade e eficácia imediata de toda a Constituição, na condição de ordem jurídico-normativa, percebe-se - na esteira de García de Enterría - que o art. $5^{\circ}, \S 1^{\circ}$, de nossa Lei Fundamental constitui, na verdade, um plus agregado às normas definidoras de direitos fundamentais, que tem por finalidade justamente a de ressaltar sua aplicabilidade imediata independentemente de qualquer medida concretizadora. Poderá afirmar-se, portanto, que - no âmbito de uma força jurídica reforçada ao nível da Constituição - os direitos fundamentais possuem, relativamente às demais normas constitucionais, maior aplicabilidade e eficácia, o que, por outro lado (consoante já assinalado), não significa que mesmo dentre os direitos fundamentais não possam existir distinções no que concerne à graduação desta aplicabilidade e eficácia, dependendo da forma de positivação, do objeto e da função que cada preceito desempenha. Negar-se aos direitos fundamentais esta condição privilegiada significaria, em última análise, negar-lhes a própria fundamentalidade. Não por outro motivo - isto é, pela sua especial relevância na Constituição - já se afirmou que, em certo sentido, os direitos fundamentais (e a estes poderíamos acrescentar os princípios fundamentais) governam a ordem constitucional”. SARLET, Ingo Wolfgang. A eficácia dos direitos fundamentais, cit., p. 285-286.

137“No direito pátrio, há quem sustente que os direitos sociais não podem, em hipótese alguma, ser considerados como integrantes das 'cláusulas pétreas' da Constituição, isso pelo fato de não poderem (ao menos na condição de direitos a prestações) ser equiparados aos direitos de liberdade do art. $5^{\circ}$. Para além disso, argumenta-se que, se o Constituinte efetivamente tivesse tido a intenção de gravar os direitos sociais com a cláusula da intangibilidade, ele o teria feito, ou nominando expressamente esta categoria de direitos no art. $60, \S 4^{\circ}$, inc. IV, ou referindo-se de forma genérica a todos os direitos e garantias fundamentais, mas não apenas aos direitos e garantias individuais. Tal concepção e todas aquelas que the podem ser equiparadas esbarram, contudo, nos seguintes argumentos: a) a Constituição brasileira não traça qualquer diferença entre os direitos de liberdade (defesa) e os direitos sociais, inclusive no que diz com eventual primazia dos primeiros sobre os segundos; b) os partidários de uma exegese conservadora e restritiva em regra partem da premissa de que todos os direitos sociais podem ser conceituados como direitos a prestações materiais estatais, quando, em verdade, já se demonstrou que boa parte dos direitos sociais são 
$\S 4^{\circ}$ - Não será objeto de deliberação a proposta de emenda tendente a abolir:

(...)

IV - os direitos e garantias individuais.

Trata-se de mais um instrumento, a atuar de forma conjunta com aquele previsto no artigo $5^{\circ}, \S 1^{\circ}$, da Constituição, como reforço eficacial das normas constitucionais veiculadoras dos direitos humanos fundamentais, agora como garantia de que não haverá retrocessos nas conquistas civilizatórias alcançadas pela via da positivação de direitos humanos fundamentais na constituição.

Ou seja, aqueles direitos humanos fundamentais já reconhecidos pela nossa carta constitucional não poderão ser objeto de extirpação ou exclusão, mesmo que por via de reforma constitucional. A vontade do legislador constituinte originário nesse particular, em nosso sistema pátrio, é intocável, o que vem ao encontro da inserção da dignidade da pessoa humana como fundamento de nossa República (art. $1^{\circ}$, III, da Constituição).

Veja que, não obstante o assunto ainda seja tema de debates e divergências entre nossos constitucionalistas pátrios, o fato é que o movimento neoconstitucionalista veio para ficar, fomentado pela carta constitucional de 1988, de cunho dirigente ${ }^{138}$.

equiparáveis, no que diz com sua função precípua e estrutura jurídica, aos direitos de defesa; c) para além disso, relembramos que uma interpretação que limita o alcance das 'cláusulas pétreas' aos direitos fundamentais elencados no art. $5^{\circ}$ da CF acaba por excluir também os direitos de nacionalidade e os direitos políticos, que igualmente não foram expressamente previstos no art. $60, \S 4^{\circ}$, inc. IV, de nossa lei Fundamental". SARLET, Ingo Wolfgang. A eficácia dos direitos fundamentais, cit., p. 431-432.

A tais observações deve ser acrescido o fato de ser único o regime jurídico constitucional protetivo dos direitos humanos fundamentais, não havendo que se falar em hierarquia entre eles, conclusão reforçada pelo princípio da unidade da constituição.

${ }^{138}$ Trata-se de constatação feita por Luís Roberto Barroso: "A preocupação com o cumprimento da Constituição, com a realização prática dos comandos nela contidos, enfim, com a sua efetividade, incorporou-se, de modo natural, à vivência jurídica brasileira pós-1988. Passou a fazer parte da précompreensão do tema, como se houvéssemos descoberto o óbvio após longa procura. As poucas situações em que o Supremo Tribunal Federal deixou de reconhecer aplicabilidade direta e imediata às normas constitucionais foram destacadas e comentadas em tom severo. Em menos de uma geração, o direito constitucional brasileiro passou da desimportância ao apogeu, tornando-se o centro formal, material e axiológico do sistema jurídico. A doutrina da efetividade serviu-se, como se deduz explicitamente da exposição até aqui desenvolvida, de uma metodologia positivista: direito constitucional é norma; e de um critério formal para estabelecer a exigibilidade de determinados direitos: se está na Constituição é para ser cumprido. O sucesso aqui celebrado não é infirmado pelo desenvolvimento de novas formulações doutrinárias, de base pós-positivista e voltadas para a fundamentalidade material da norma. Entre nós talvez diferentemente do que se passou em outras partes -, foi a partir do novo patamar criado pelo constitucionalismo brasileiro da efetividade que ganharam impulso os estudos acerca do neoconstitucionalismo e da teoria dos direitos fundamentais". BARROSO, Luís Roberto. O direito constitucional e a efetividade de suas normas, cit., p. 247-248. Confira-se, ademais: SARMENTO, Daniel. op. cit., p. 245-255. 
E é Dalmo de Abreu Dallari ${ }^{139}$ quem nos dá um resumo das principais características desse novo movimento constitucional "neoconstitucionalista": i) caráter universalizante da constituição; ii) constituição como documento fundado em valores éticos, jurídicos $e$ sociais; iii) constituição como ápice do ordenamento jurídico da nação e parâmetro interpretativo das normas infraconstitucionais (fenômeno chamado de "onipresença da constituição"), dotado de normas jurídicas superiores e vinculantes, de aplicação imediata, inclusive, no tocante aos seus princípios informadores.

Reputo demonstrado, por todo o exposto, como a história do surgimento e evolução das constituições e do movimento constitucionalista sofreu notável influência do movimento em prol dos direitos humanos fundamentais, sendo fruto de inúmeras lutas pelo reconhecimento da pessoa humana como sujeito de direitos, bem como do processo de individualização da pessoa humana ("sacralização da pessoa"), a tal ponto que, no atual estágio de desenvolvimento da ciência do direito - notadamente no direito constitucional não é possível se falar em um tema sem que se refira ao outro, servindo cada qual como fundamento de validade do outro, mas, ambos entendidos como conquistas civilizatórias em prol da pessoa humana e em um caminho de paz social duradoura.

$\mathrm{Na}$ verdade, ambos os temas estão intimamente ligados, sendo ínsitos ao próprio desenvolvimento das sociedades humanas, representando evolução científica seu estudo conjugado, sendo que, somente assim, é possível se ter uma visão ampla e geral do processo de evolução da humanidade e de dois dos seus principais institutos artificiais de funcionamento e disciplina: Estado e Direito.

A partir do próximo capítulo, procurarei demonstrar como o arsenal normativo constitucional, interpretado à luz do neoconstitucionalismo, faz com que os direitos humanos fundamentais plasmados nas cartas constitucionais dos países ocidentais ganhem uma eficácia ímpar na história da humanidade, sendo dever estatal e da própria sociedade o cumprimento e efetivação de tais direitos.

${ }^{139}$ DALLARI, Dalmo de Abreu. A Constituição na vida dos povos. São Paulo: Saraiva, 2010. p. 287-327. 


\section{A FORÇA NORMATIVA DA CONSTITUIÇÃO E SEUS REFLEXOS SOBRE OS DIREITOS SOCIAIS: OS TEMAS DA FORÇA NORMATIVA DOS PRINCÍPIOS CONSTITUCIONAIS, DA DIGNIDADE DA PESSOA HUMANA, DA VEDAÇÃO DO RETROCESSO SOCIAL E DO DIREITO ADQUIRIDO SOCIAL}

\subsection{Caráter fundamental dos direitos sociais}

Procurei demonstrar, ao longo dos três primeiros capítulos, que os processos de surgimento, sedimentação, positivação e ampliação dos direitos humanos fundamentais e do constitucionalismo são duas faces de uma mesma moeda: um processo de lutas pelo reconhecimento da pessoa humana como sujeito de direitos.

No atual estágio, não há mais preocupação com relação ao reconhecimento e positivação desses dois mecanismos de proteção da pessoa humana: os direitos humanos fundamentais fazem parte de quase todas as cartas constitucionais dos Estados Nacionais, os quais, por seu turno, possuem invariavelmente uma Constituição, como ápice do sistema jurídico vigente.

Ademais, a "via de mão dupla" existente entre os dois sistemas protetivos é realidade pacífica entre os doutrinadores, no sentido de um extrair do outro seu fundamento de validade e de se utilizar do outro para a irradiação de efeitos jurídicos ${ }^{140}{ }^{141}$.

A maior preocupação nos dias atuais é com a efetividade, com o cumprimento dos comandos plasmados nas constituições ao redor do globo, pois, não obstante as previsões e

\footnotetext{
${ }^{140}$ Aqui no Brasil, confira-se o escólio de Ingo Wolfgang Sarlet: “Com base nas ideias aqui apenas pontualmente lançadas e sumariamente desenvolvidas, há como sustentar que, além da íntima vinculação entre as noções de Estado de Direito, Constituição e direitos fundamentais, estes, sob o aspecto de concretizações do princípio da dignidade da pessoa humana, bem como dos valores da igualdade, liberdade e justiça, constituem condição de existência e medida da legitimidade de um autêntico Estado Democrático e Social de Direito, tal qual como consagrado também em nosso direito constitucional positivo vigente". SARLET, Ingo Wolfgang. A eficácia dos direitos fundamentais, cit., p. 74.

${ }^{141}$ Confira-se escólio de José Joaquim Gomes Canotilho: "A positivação constitucional não significa que os direitos fundamentais deixem de ser elementos constitutivos da legitimidade constitucional, e, por conseguinte, elementos legitimativo-fundamentantes da própria ordem jurídico-constitucional positiva, nem que a simples positivação jurídico-constitucional os torne, só por si, <realidades jurídicas efectivas > (ex. catálogo de direitos fundamentais em constituições meramente semânticas). Por outras palavras: a positivação jurídico-constitucional não <dissolve $>$ nem $<$ consome $>$ quer $o$ momento de $<$ jusnaturalização $>$ quer as raízes fundamentantes dos direitos fundamentais (dignidade humana, fraternidade, igualdade, liberdade). Neste sentido se devem interpretar logo os arts. $1^{\circ}$ e $2^{\circ}$ da CRP, ao basearem, respectivamente, a República na <dignidade da pessoa humana $>\left(\operatorname{art.~} 1^{\circ}\right)$, e o Estado de direito democrático no <respeito e na garantia de efectivação dos direitos e liberdades fundamentais>". CANOTILHO, José Joaquim Gomes. op. cit., p. 378.
} 
a criação de mecanismos constitucionais para a eficácia de tais direitos - vide o caso brasileiro, com os mecanismos já estudados da aplicabilidade imediata das normas constitucionais que versam sobre direitos humanos fundamentais e sua inserção dentre as chamadas "cláusulas pétreas" - ainda persiste forte resistência por parte da doutrina e dos próprios governos no cumprimento dos comandos constitucionais, notadamente em se tratando de direitos humanos fundamentais sociais ${ }^{142}$.

$\mathrm{Na}$ verdade, boa parte da celeuma doutrinária acerca do caráter fundamental (ou não) dos direitos sociais se dá em razão da enorme influência da doutrina constitucionalista alemã nos demais países europeus, bem como na América Latina - inclusive no Brasil.

Isso porque, na Alemanha, os direitos humanos fundamentais sociais não se encontram positivados na carta constitucional, qualificadora do modelo de Estado adotado como sendo uma "República Federativa". Lá, apenas há menção à cláusula genérica e aberta de que o Estado alemão se constitui em um "Estado Social".

Ao contrário, no Brasil e em Portugal as respectivas cartas constitucionais trazem generoso rol de direitos humanos fundamentais sociais, além de mecanismos de proteção e efetividade de tais direitos: os já mencionados e estudados mecanismos da aplicabilidade imediata e vedação de reforma constitucional supressiva.

Sucede que a doutrina pátria acabou por internalizar conceitos e desenvolvimentos doutrinários realizados na Alemanha, sem um olhar crítico, de adaptação dos modelos para a nossa realidade, na qual todos os direitos humanos fundamentais contam com elevado grau de positivação e proteção constitucionais, inclusive os sociais, todos inseridos dentro de um regime jurídico protetivo único ${ }^{143}$.

\footnotetext{
${ }^{142}$ Resistência que não possui mais razão de ser, conforme muito bem observado por Jorge Reis Novais, em exemplar passagem a ser sempre rememorada: "Com efeito, quando uma Constituição consagra e reconhece inequivocamente os direitos sociais como direitos fundamentais, elencando-os, de resto, de forma muito pormenorizada e desenvolvida, toda a discussão sobre a sua controversa natureza jusfundamental perde grande parte do sentido. Portanto, se, como acontece entre nós, o legislador constituinte, atendendo à respectiva fundamentalidade no quadro de um Estado social e democrático de Direito, intencionalmente acolhe os direitos sociais como direitos fundamentais, podemos discutir o alcance desse reconhecimento, podemos discutir o que significa ser um direito fundamental, mas deixa de fazer sentido consumir o essencial dos esforços dogmáticos a apurar se há ou não, e com que fundamentos, direitos constitucionais sociais". NOVAIS, Jorge Reis. op. cit., p. 84.

${ }^{143} \mathrm{Tal}$ crítica foi muito bem sintetizada por Jorge Reis Novais: "Logo, a base de partida é qualitativamente diferente da alemã, o que tem implicações dogmáticas não negligenciáveis. Assim, entre nós, os direitos sociais, sendo direitos fundamentais constitucionais, gozam, portanto, à partida, do regime dos direitos fundamentais enquanto normas jurídicas vinculativas de força superior e gozam desse regime relativamente a todo o seu conteúdo, tal como os direitos de liberdade, e não apenas relativamente a um dificilmente delimitável 'mínimo social'. Da mesma forma, não se vê qual o préstimo do conceito dos direitos sociais derivados, os famosos direitos derivados a prestações, quando, em paralelo, não há conhecimento que alguém entre nós tenha sustentado a existência de análoga distinção entre direitos originários de liberdade
} 
O fato é que a constituição alemã não positivou direitos humanos fundamentais sociais de forma individualizada, mas isso não significa que a doutrina não os reconheça, bem como sua respectiva proteção, na ordem constitucional. Ao revés, os conceitos mencionados por Jorge Reis Novais representam exatamente um olhar neoconstitucionalista sobre a carta constitucional alemã, extraindo do princípio aberto e indeterminado do "Estado Social" a carga normativa necessária para fazer valer tais direitos ${ }^{144}$.

Ou seja, mesmo em um sistema normativo constitucional como o alemão, em que não há positivação específica de direitos humanos fundamentais sociais, a doutrina constitucional conseguiu criar um sistema protetivo de elevada envergadura e carga eficacial.

\subsection{Mecanismos neoconstitucionais de garantia e eficácia dos direitos sociais}

Como foi possível tal empreitada? A resposta é imediata: pela via do neoconstitucionalismo, com uma interpretação inovadora, concretista, de normas constitucionais veiculadoras de princípios - no caso, o princípio do Estado Social.

Aqui já surge talvez o maior legado do neoconstitucionalismo em termos de interpretação constitucional: a força normativa dos princípios constitucionais.

É o que passo a estudar.

\subsubsection{Força normativa dos princípios constitucionais}

Em termos de evolução histórica, a doutrina somente conceituava as regras como normas jurídicas dotadas de eficácia - conceito aqui entendido como irradiação de efeitos jurídicos no mundo fenomênico ou, em outras palavras, a concretização dos comandos normativos no mundo do ser (passagem do mundo do dever-ser para o mundo do ser).

Aos princípios sempre foi relegado um papel secundário, de instrumento de colmatação de lacunas, de integração do direito, conforme regras clássicas de nosso

e direitos derivados a liberdade. Tal como, por último, não se percebe por que razão estariam os direitos sociais protegidos por um pretenso e nebuloso princípio constitucional da vedação do retrocesso social quando, em paralelo, ninguém sustenta a análoga existência de um princípio constitucional da proibição do retrocesso liberal”. NOVAIS, Jorge Reis. op. cit., p. 84-85. A crítica é contundente e com ela concordo apenas no tocante ao olhar crítico, de que a doutrina simplesmente importa conceitos e definições sem adaptá-los ou realizar um filtro de compatibilidade com nosso sistema constitucional, muito diverso do alemão em termos de positivação e proteção de direitos humanos fundamentais sociais. Quanto ao mérito, o tema da vedação do retrocesso me parece ser um caso de conceito importante e didático, que pode muito bem ser importado e utilizado no Brasil, o que restará demonstrado adiante.

${ }^{144}$ Confira-se, neste exato sentido, o escólio de dois grandes juristas alemães: i) HESSE, Konrad. Elementos de direito constitucional da República Federal da Alemanha, cit., p. 175; ii) ALEXY, Robert. Teoria discursiva do direito. Tradução de Alexandre Travessoni Gomes Trivisonno. Rio de Janeiro: Forense Universitária, 2014. p. 127. 
ordenamento jurídico pátrio: i) art. $4^{\circ}$, do Decreto-lei n. 4.657/42 (Lei de Introdução às Normas do Direito Brasileiro) ${ }^{145}$; ii) art. 126, $2^{\mathrm{a}}$ parte, do Código de Processo Civil (norma direcionada ao magistrado) ${ }^{146}$.

Tal ainda era o período no qual o centro do ordenamento jurídico estatal era o Código Civil, que vigorou mesmo com o advento da constituição e do movimento constitucionalista, alcançando o seu auge com o Código Civil napoleônico, editado com a pretensão de regular todas as possíveis relações humanas em termos de disciplina jurídica.

Nesse diapasão, é certo que os códigos sempre disciplinaram relações jurídicas interpessoais, com a veiculação de típicas regras de comportamento, e não de normas veiculadoras de princípios, balizas e valores a serem seguidos, estes últimos inseridos pelo legislador ordinário sempre de forma enxuta e introdutória em cada código de condutas, com o fim mesmo de colmatação de eventuais lacunas legais.

Com o deslocamento paulatino do centro do sistema jurídico para a constituição, bem como da positivação de uma série de valores, de balizas, de nortes, de orientações a serem observadas pelos órgãos estatais (Executivo, Legislativo e Judiciário), pela coletividade e por cada pessoa individualmente, também se modifica a compreensão do que deva ser conceituado como norma jurídica, uma vez que a constituição, de mero documento político, passou a constituir o centro dos ordenamentos jurídicos estatais, gozando de supremacia sobre as demais normas jurídicas do sistema e irradiando efeitos jurídicos por todo o sistema normativo estatal.

Assim, tais normas, positivadoras de diretivas a serem observadas até mesmo pelo próprio legislador ordinário em sua tarefa cotidiana, passam a ter eficácia, concretude jurídica, vinculando os atores sociais e seus comportamentos.

Tal movimento tem o seu ápice quando do advento do pós-positivismo e sua vertente constitucional - o neoconstitucionalismo - quando os princípios passam a integrar o conceito de norma jurídica, como uma espécie de tal gênero - ao lado das tradicionais regras ${ }^{147}$.

\footnotetext{
145“"Quando a lei for omissa, o juiz decidirá o caso de acordo com a analogia, os costumes e os princípios gerais de direito".

${ }^{146 “}$ "No julgamento da lide caber-lhe-á aplicar as normas legais; não as havendo, recorrerá à analogia, aos costumes e aos princípios gerais de direito".

${ }^{147}$ Tal movimento é muito bem sintetizado e percebido por Márcio Luís de Oliveira: "Numa primeira etapa do processo de sistematização dogmática do Direito, a simbiose entre a noção de normatividade jurídica com a de legalidade formal (característica marcante e compreensível no pensamento jurídico do século XIX e meados do século XX) provocou uma forte reação e 'retorno' do pensamento jusnaturalista, ainda no final do século XIX e início do XX, sob inspiração iluminista-humanista. Até então, a proliferação dos Códigos Civis ocorrida na Europa e na América Latina fazia uma inexpressiva menção aos 'princípios
} 
Não é sem razão que ganhou enorme prestígio e repercussão internacional o conceito contemporâneo de constituição como "sistema aberto de regras e princípios" 148 , o que só elevou ainda mais a importância dos princípios jurídicos como espécie normativa dotada de eficácia jurídica ${ }^{149}$.

Fica claro, pois, que são o pós-positivismo e sua vertente constitucional do neoconstitucionalismo que guindam os princípios jurídicos ao patamar de normas jurídicas dotadas de eficácia normativa, passando a ombrear com as regras jurídicas, como duas espécies pertencentes ao gênero das normas jurídicas.

gerais do Direito' como fontes normativas subsidiárias. Contudo, o culto à legalidade formal já estava tão arraigado na cultura jurídico-ocidental do século XIX que a doutrina positivista praticamente não dedicava qualquer estudo mais aprofundado aos 'princípios gerais do Direito', conquanto a prática jurídica lhes reservava uma função absolutamente secundária e irrelevante na operacionalização do Direito vigente à época, quando eram eles invocados apenas em caráter subsidiário e como resultado da aplicabilidade de métodos de integração do Direito. Assim, os princípios jurídicos foram tratados, pela reação jusnaturalista do século XIX e início do século XX, como 'máximas jusfilosóficas' justificadoras de um Direito que deveria respaldar-se na moralidade e na eticidade, e ser focalizado no ideal de justiça. Logo, sob aquele ponto de vista, os princípios não eram normas jurídicas formais (não detinham normatividade jurídica), mas ofereciam substratos de natureza axiológico-racional-liberal de inspiração para o 'ordenamento jurídico'. (...) Porém, os graves retrocessos políticos e jurídicos ocorridos na primeira metade do século XX (especialmente as ideologias e os fatos precedentes e presentes na Segunda Guerra Mundial) provocaram o ressurgimento - na compreensão contemporânea da jusfilosofia, da Ciência Jurídica e da Dogmática Jurídica - das discussões sobre os fundamentos humanísticos do Direito e sobre a dinâmica ético-racional do sistema jurídico, inserido, sobretudo, numa sociedade democrática, altamente diversificada e complexa, e de estruturas plurissistêmicas. Logo, as concepções pós-positivistas e neoconstitucionalistas que vêm sendo elaboradas desde o fim da década de 1940 passaram progressivamente a reconhecer normatividade/juridicidade aos princípios jurídicos (...). Assim, no alvorecer do século XXI, não resta mais dúvida alguma acerca da normatividade jurídica dos princípios de Direito. E nem poderia ser diferente, pois como seria possível os princípios jurídicos não serem normas jurídicas se o Direito é um sistema de normas jurídicas e se os princípios jurídicos são manifestações do próprio fenômeno jurídico sistemicamente compreendido e experienciado?" OLIVEIRA, Márcio Luís de. op. cit., p. 165-167. Confirase, outrossim: BARROSO, Luís Roberto. Curso de direito constitucional contemporâneo, cit., p. 226-227.

${ }^{148} \mathrm{Tal}$ conceito, muito difundido no Brasil por José Joaquim Gomes Canotilho, foi criado por Konrad Hesse, um dos pais do neoconstitucionalismo, para quem é esta percepção - da Constituição como sistema aberto de regras e princípios - que demonstra a importância e variedade de mecanismos necessários à interpretação constitucional - muito além das tradicionais técnicas de interpretação das regras jurídicas veiculadas por lei -, como atividade voltada à concretização do direito constitucional: "Para o Direito Constitucional, interpretação tem importância decisiva porque, em vista da abertura e amplitude da Constituição, problemas de interpretação nascem mais frequentemente do que em âmbitos jurídicos, cujas normalizações entram mais no detalhe". HESSE, Konrad. Elementos de direito constitucional da República Federal da Alemanha, cit., p. 54.

${ }^{149}$ Confira-se o escólio de Canotilho sobre o tema: "Convém, por isso, adiantar o ponto de partida fundamental para a compreensão dos desenvolvimentos seguintes: o sistema jurídico do Estado de direito democrático português é um sistema normativo aberto de regras e princípios. Este ponto de partida carece de <descodificação>: (1) é um sistema jurídico porque é um sistema dinâmico de normas; (2) é um sistema aberto porque tem uma estrutura dialógica (Caliess), traduzida na disponibilidade e <capacidade de aprendizagem $>$ das normas constitucionais para captarem a mudança da realidade e estarem abertas às concepções cambiantes da $<$ verdade $>$ e da $<$ justiça $>$; (3) é um sistema normativo, porque a estruturação das expectativas referentes a valores, programas, funções e pessoas, é feita através de normas; (4) é um sistema de regras e de princípios, pois as normas do sistema tanto podem revelar-se sob a forma de princípios como sob a forma de regras". CANOTILHO, José Joaquim Gomes. op. cit., p. 1159. Para aprofundamento sobre o assunto, confiram-se as páginas seguintes: 1159-1190. 
A partir de tal modelo doutrinário, deixa de existir hierarquia entre regras $e$ princípios jurídicos: ambos possuem a mesma dignidade e posição no sistema, veiculando comandos normativos que devem ser seguidos pelos diversos atores sociais, sob pena de incidirem em sanção.

Porém, não obstante a força normativa dos princípios constitucionais seja entendimento pacífico e corrente entre os neoconstitucionalistas, o fato é que a definição de uma norma jurídica como sendo regra ou princípio varia de acordo com certas correntes doutrinárias atualmente vigentes ${ }^{150}$.

Outrossim, que fique claro desde já que as diversas normas jurídicas constitucionais não possuem a mesma carga eficacial, a qual varia de acordo com classificações propostas por diversos doutrinadores ao longo da própria evolução do constitucionalismo. Se não há dúvidas de que não existem normas jurídicas constitucionais desprovidas de carga eficacial, também é certo que não há normas jurídicas que se sobreponham a outras, ou seja, não há regras ou princípios absolutos ${ }^{151}$ em sede constitucional, do que decorre exatamente a noção de unidade das normas jurídicas constitucionais, assunto já abordado no capítulo anterior ${ }^{152}$. Tal noção será de extrema relevância quando estudar a eficácia das

\footnotetext{
${ }^{150}$ Não faz parte deste trabalho o estudo das diversas formas de diferenciação entre as duas espécies de normas jurídicas (regras e princípios), mas, basta dizer que os critérios utilizados são, usualmente, os seguintes: i) conteúdo; ii) origem e validade; iii) compromisso histórico; iv) função no ordenamento; v) estrutura linguística; vi) esforço interpretativo exigido; vii) aplicação. Para maior aprofundamento sobre o assunto, inclusive, com indicações de autores a serem consultados, confira-se: i) BARCELLOS, Ana Paula de. A eficácia jurídica dos princípios constitucionais: o princípio da dignidade da pessoa humana. 3. ed. Rio de Janeiro: Renovar, 2011. p. 50-57; ii) ÁVILA, Humberto. Teoria dos princípios: da definição à aplicação dos princípios jurídicos. 12. ed. ampl. São Paulo: Malheiros Ed., 2011. p. 35-64.

${ }^{151} \mathrm{~A}$ inexistência de princípios absolutos entendidos como normas jurídicas constitucionais dentro de um sistema garantidor de direitos humanos fundamentais é muito bem defendida e explicada por Robert Alexy: "É fácil argumentar contra a existência de princípios absolutos em um ordenamento jurídico que inclua direitos fundamentais. Princípios podem se referir a interesses coletivos ou a direitos individuais. Se um princípio se refere a interesses coletivos e é absoluto, as normas de direitos fundamentais não podem estabelecer limites jurídicos a ele. Assim, até onde o princípio absoluto alcançar não pode haver direitos fundamentais. Se o princípio absoluto garante direitos individuais, a ausência de limites desse princípio levaria à seguinte situação contraditória: em caso de colisão, os direitos de cada indivíduo, fundamentados pelo princípio absoluto, teriam que ceder em favor dos direitos de todos os indivíduos, também fundamentados pelo princípio absoluto. Diante disso, ou os princípios absolutos não são compatíveis com direitos individuais, ou os direitos individuais que sejam fundamentados pelos princípios absolutos não podem ser garantidos a mais de um sujeito de direito.” ALEXY, Robert. Teoria dos direitos fundamentais, cit., p. 111.

${ }^{152}$ Neste trabalho não será analisado de forma ampla o tema da evolução da eficácia normativa dos princípios constitucionais, fruto do pós-positivismo e do neoconstitucionalismo; apenas no tocante à eficácia dos princípios constitucionais veiculadores de direitos humanos fundamentais sociais. Tal tema será abordado do capítulo 5 dentro do contexto da justiciabilidade dos direitos sociais e de dois conceitos elaborados e consagrados pela doutrina constitucionalista acerca do assunto: mínimo existencial e reserva do possível. Dentro deste assunto, basta lembrar que, já na década de 1960, José Afonso da Silva defendia a eficácia jurídica de todas as normas jurídicas constitucionais veiculadoras de princípios, quando da elaboração de sua teoria tripartite no tocante à eficácia das normas jurídicas constitucionais: i) normas de eficácia plena e aplicabilidade imediata; ii) normas de eficácia contida e aplicabilidade imediata; iii) normas programáticas,
} 
normas jurídicas veiculadoras de direitos humanos fundamentais sociais, as quais, no mais das vezes, assumem a forma de princípios - não obstante em nosso sistema constitucional pátrio existam inúmeras regras tratando de tais direitos.

De qualquer sorte, adoto para efeitos deste estudo a posição defendida por Robert Alexy - importada por Canotilho para o modelo português e por Virgílio Afonso da Silva para o modelo brasileiro -, para quem os princípios devem ser entendidos como "mandamentos de otimização".

Antes de se chegar a tal conclusão, bem como de melhor explicitá-la, é importante salientar que a diferenciação entre regras e princípios jurídicos é a base de um esforço argumentativo maior levado a cabo por Robert Alexy: tal diferenciação é a chave para uma teoria dos direitos fundamentais ${ }^{153} 154$.

Alexy inclui ambos os elementos - regras e princípios - no conceito mais abrangente de normas jurídicas - seguindo o norte pós-positivista e neoconstitucionalista ao afirmar:

de eficácia limitada e aplicabilidade diferida, porém, com produção imediata de três efeitos mínimos: negativo (impedir que o legislador legisle de forma contrária ao comando constitucional), ordenador (incitar à produção legislativa que dê concretização ao comando constitucional) e interpretativo. Para maior aprofundamento sobre a evolução do pensamento acerca da classificação das normas constitucionais em termos eficaciais, confira-se: i) BARCELLOS, Ana Paula de. op. cit., p. 46-50; ii) BARROSO, Luís Roberto. Curso de direito constitucional contemporâneo, cit., p. 235-240; iii) SARLET, Ingo Wolfgang; MARINONI, Luiz Guilherme; MITIDIERO, Daniel. Curso de direito constitucional, cit., p. 155-180; iv) MELLO, Celso Antônio Bandeira de. op. cit.; v) SILVA, Virgílio Afonso da. Direitos fundamentais: conteúdo essencial, restrições e eficácia. 2. ed. 2 tir. São Paulo: Malheiros Ed., 2011. p. 208-251.

${ }^{153}$ Alexy deixa tal ligação muito clara, da seguinte forma: "Para a teoria dos direitos fundamentais, a mais importante delas é a distinção entre regras e princípios. Essa distinção é a base da teoria da fundamentação no âmbito dos direitos fundamentais e uma chave para a solução de problemas centrais da dogmática dos direitos fundamentais. Sem ela não pode haver nem uma teoria adequada sobre as restrições a direitos fundamentais, nem uma doutrina satisfatória sobre colisões, nem uma teoria suficiente sobre o papel dos direitos fundamentais no sistema jurídico. Essa distinção constitui um elemento fundamental não somente da dogmática dos direitos de liberdade e de igualdade, mas também dos direitos a proteção, a organização e procedimento e a prestações em sentido estrito. Com sua ajuda, problemas como os efeitos dos direitos fundamentais perante terceiros e a repartição de competências entre tribunal constitucional e parlamento podem ser mais bem esclarecidos. A distinção entre regras e princípios constitui, além disso, a estrutura de uma teoria normativo-material dos direitos fundamentais e, com isso, um ponto de partida para a resposta à pergunta acerca da possibilidade e dos limites da racionalidade no âmbito dos direitos fundamentais. Nesse sentido, a distinção entre regras e princípios é uma das colunas-mestras do edifício da teoria dos direitos fundamentais". ALEXY, Robert. Teoria dos direitos fundamentais, cit., p. 85.

${ }^{154}$ No Brasil, quem melhor tratou de tal questão foi Virgílio Afonso da Silva, que também faz tal advertência no início de sua obra, nos seguintes termos: "Ainda que este não seja um trabalho sobre a distinção entre regras e princípios, será facilmente perceptível que muitas de suas conclusões dependerão diretamente do pressuposto teórico adotado nesse âmbito. Como será visto em capítulos seguintes, não somente o conceito e a delimitação do conteúdo essencial dos direitos fundamentais poderão variar segundo o conceito de princípio que se adote; também a forma de se definir o âmbito de proteção de cada direito fundamental, de reconstruir a relação entre os direitos e suas restrições e, por fim, a crítica às teorias sobre a eficácia das normas constitucionais serão determinadas a partir desse primeiro pressuposto teórico". SILVA, Virgílio Afonso da. op. cit., p. 43. 
Aqui, regras e princípios serão reunidos sob o conceito de norma. Tanto regras quanto princípios são normas, porque ambos dizem o que deve ser. Ambos podem ser formulados por meio das expressões deônticas básicas do dever, da permissão e da proibição. Princípios são, tanto quanto as regras, razões para juízos concretos de dever-ser, ainda que de espécie muito diferente. A distinção entre regras e princípios é, portanto, uma distinção entre duas espécies de normas ${ }^{155}$.

Após discorrer sobre os diversos critérios utilizados para efeitos de distinção entre regras e princípios ${ }^{156}$, conclui sobre o critério que considera mais apropriado e útil, qual seja, o qualitativo.

Por ele, enquanto as regras veiculam determinações, que podem ou não ser satisfeitas (lógica do "tudo ou nada"), os princípios veiculam mandamentos de otimização, cuja realização varia de grau, de acordo com as possibilidades fáticas e jurídicas existentes no momento de sua observância ${ }^{157}$.

Veja, pois, que enquanto as regras trazem comandos que devem ser impreterivelmente observados pelos destinatários, sob pena de invariavelmente incidir em sanção jurídica fixada no seu consequente normativo - daí a noção de "tudo ou nada", que é utilizada para a definição das regras - os princípios trazem mandamentos que devem ser observados pelos destinatários, porém, dentro das possibilidades fáticas e jurídicas existentes e observadas quando do cumprimento do mandamento - daí porque se fala em "mandamento de otimização".

Trata-se da consagrada distinção entre direitos definitivos (caso das regras) e direitos prima facie (caso dos princípios) ${ }^{158}$.

\footnotetext{
${ }^{155}$ ALEXY, Robert. Teoria dos direitos fundamentais, cit., p. 87.

${ }^{156}$ Id. Ibid., p. 87-90.

${ }^{157} \mathrm{Tal}$ é o escólio de Alexy sobre o assunto: "O ponto decisivo na distinção entre regras e princípios é que princípios são normas que ordenam que algo seja realizado na maior medida possível dentro das possibilidades jurídicas e fáticas existentes. Princípios são, por conseguinte, mandamentos de otimização, que são caracterizados por poderem ser satisfeitos em graus variados e pelo fato de que a medida devida de sua satisfação não depende somente das possibilidades fáticas, mas também das possibilidades jurídicas. $\mathrm{O}$ âmbito das possibilidades jurídicas é determinado pelos princípios e regras colidentes. Já as regras são normas que são sempre ou satisfeitas ou não satisfeitas. Se uma regra vale, então, deve se fazer exatamente aquilo que ela exige; nem mais, nem menos. Regras contêm, portanto, determinações no âmbito daquilo que é fática e juridicamente possível. Isso significa que a distinção entre regras e princípios é uma distinção qualitativa, e não uma distinção de grau. Toda norma é ou uma regra ou um princípio". Id. Ibid., p. 90-91.

${ }^{158}$ A propósito, confira-se elucidativo escólio de Virgílio Afonso da Silva: "O principal traço distintivo entre regras e princípios, segundo a teoria dos princípios, é a estrutura dos direitos que essas normas garantem. No caso das regras, garantem-se direitos (ou se impõem deveres) definitivos, ao passo que no caso dos princípios são garantidos direitos (ou são impostos deveres) prima facie. Isso significa que, se um direito é garantido por uma norma que tenha a estrutura de uma regra, esse direito é definitivo e deverá ser realizado totalmente, caso a regra seja aplicável ao caso concreto. E claro que, como será visto adiante, regras podem
} 
Duas consequências jurídicas de grande envergadura emergem de imediato de tal concepção: i) as regras veiculam um mandamento definitivo, pelo que se submetem inexoravelmente à lógica do cumprimento/descumprimento, enquanto no caso dos princípios se está diante de um mandamento prima facie, que ainda deve passar pelo crivo das "possibilidades fáticas e jurídicas" existentes e observadas quando do cumprimento do mandamento, o que pode levar a um não cumprimento autorizado pela impossibilidade prática $^{159}$; ii) a incompatibilidade entre regras gera um conflito, uma antinomia, necessariamente solucionada pela adoção de uma e extirpação da outra do ordenamento jurídico (métodos tradicionais de solução de antinomias), enquanto que a incompatibilidade entre princípios leva a uma colisão, que não gera a extirpação de um deles do ordenamento, mas, a uma solução pela via da interpretação integrativa de ambos (“sopesamento"), verificando-se qual deve prevalecer em dado caso concreto ${ }^{160}$.

Mais adiante, Alexy traz a correlação intrínseca entre normas jurídicas veiculadoras de princípios e a máxima da proporcionalidade, como método de solução das colisões entre princípios ${ }^{161}$.

ter - e quase sempre têm - exceções. Isso não altera o raciocínio, já que as exceções a uma regra devem ser tomadas como se fossem parte da própria regra excepcionada. Assim, a regra que proíbe a retroação da lei penal tem uma conhecida exceção: a lei deve retroagir quando beneficiar o réu (CF, art. $\left.5^{\circ}, \mathrm{XL}\right)$. A norma (regra) deve, nesse caso, ser compreendida como 'é proibida a retroação de leis penais, a não ser que sejam mais benéficas para o réu que a lei anterior; nesses casos, deve haver retroação’. No caso dos princípios não se pode falar em realização sempre total daquilo que a norma exige. Ao contrário: em geral essa realização é apenas parcial. Isso, porque no caso dos princípios há uma diferença entre aquilo que é garantido (ou imposto) prima facie e aquilo que é garantido (ou imposto) definitivamente. Pode-se dizer que o longo caminho entre um (o 'prima facie') e outro (o 'definitivo') é um dos temas centrais deste trabalho". SILVA, Virgílio Afonso da. op. cit., p. 45-46.

${ }^{159}$ Id. Ibid., p. 103-106.

${ }^{160}$ Id. Ibid., p. 91-103.

161“Já se deu a entender que há uma conexão entre a teoria dos princípios e a máxima da proporcionalidade. Essa conexão não poderia ser mais estreita: a natureza dos princípios implica a máxima da proporcionalidade, e essa implica aquela. Afirmar que a natureza dos princípios implica a máxima da proporcionalidade significa que a proporcionalidade, com suas três máximas parciais da adequação, da necessidade (mandamento do meio menos gravoso) e da proporcionalidade em sentido estrito (mandamento do sopesamento propriamente dito), decorre logicamente da natureza dos princípios, ou seja, que a proporcionalidade é deduzível dessa natureza. (...) Princípios são mandamentos de otimização em face das possibilidades jurídicas $e$ fáticas. A máxima da proporcionalidade em sentido estrito, ou seja, exigência de sopesamento, decorre da relativização em face das possibilidades jurídicas. Quando uma norma de direito fundamental com caráter de princípio colide com um princípio antagônico, a possibilidade jurídica para a realização dessa norma depende do princípio antagônico. Para se chegar a uma decisão é necessário um sopesamento nos termos da lei de colisão. Visto que a aplicação de princípios válidos - caso sejam aplicáveis - é obrigatória, e visto que para essa aplicação, nos casos de colisão, é necessário um sopesamento, o caráter principiológico das normas de direito fundamental implica a necessidade de um sopesamento quando elas colidem com princípios antagônicos. Isso significa, por sua vez, que a máxima da proporcionalidade em sentido estrito é deduzível do caráter principiológico das normas de direitos fundamentais. A máxima da proporcionalidade em sentido estrito decorre do fato de princípios serem mandamentos de otimização em face das possibilidades jurídicas. Já as máximas da necessidade e da adequação decorrem da natureza dos princípios como mandamentos de otimização em face das possibilidades fáticas”. ALEXY, Robert. Teoria dos direitos fundamentais, cit., p. 117-118. 
Trata-se do critério original de solução de colisão entre princípios constitucionais veiculadores de direitos humanos fundamentais e outros princípios constitucionais, adotado por José Joaquim Gomes Canotilho ${ }^{162}$ (Portugal) e Virgílio Afonso da Silva ${ }^{163}$ (Brasil).

Qual o ganho proporcionado pela adoção de tal teoria em termos de maximização da eficácia dos direitos humanos fundamentais - inclusive sociais?

Não obstante seja assunto a ser abordado com mais vagar no próximo capítulo, tenho que a resposta é dada de forma cabal e objetiva por Virgílio Afonso da Silva:

\begin{abstract}
O modelo aqui defendido, por alargar o âmbito de proteção dos direitos fundamentais ao máximo e considerar toda e qualquer regulamentação como uma potencial - ou real - restrição, ao mesmo tempo em que coloca os termos do problema às claras - direitos fundamentais são restringíveis -, impõe um ônus argumentativo àquele responsável pela restrição, que não está presente em modelos que escamoteiam essas restrições por meio de definições de limites quase jusnaturalistas aos direitos fundamentais ou que escondem restrições atrás do conceito de regulamentação ${ }^{164}$. (grifado)
\end{abstract}

Repito que tal conclusão não deve gerar qualquer clamor ou insurgência exacerbados em sede doutrinária dentro do tema da eficácia das normas jurídicas veiculadoras de direitos humanos fundamentais - inclusive sociais - pois, conforme já exaustivamente demonstrado, tais normas são qualificadas, em sua grande maioria, como princípios constitucionais, logo, submetendo-se aos critérios interpretativos da unidade da constituição e da vedação de atribuição de caráter absoluto aos princípios constitucionais, o que veda a adoção das soluções tradicionais interpretativas de antinomia (aplicáveis unicamente às regras jurídicas) para a resolução das colisões entre princípios constitucionais.

O modelo adotado por Alexy, Canotilho e Virgílio Afonso da Silva tem o grande mérito de racionalizar e tornar clara a diferenciação estrutural entre regras e princípios, permitindo a elaboração de uma teoria congruente e sólida em termos de enfrentamento e solução das colisões entre normas jurídicas veiculadoras de direitos humanos fundamentais, com um norte claro voltado à maximização da efetividade de tais comandos normativos ("otimização" dos comandos veiculadores de direitos humanos fundamentais, nos dizeres de Alexy).

\footnotetext{
${ }^{162}$ CANOTILHO, José Joaquim Gomes. op. cit., p. 1274.

${ }^{163}$ SILVA, Virgílio Afonso da. op. cit., p. 178-179.

${ }^{164}$ Id. Ibid., p. 41.
} 
Para encerrar, apresento rapidamente a divergência doutrinária no critério de classificação das normas jurídicas entre regras e princípios apresentada por Humberto Ávila, de grande repercussão mundial.

Após criticar o modelo de distinção entre regras e princípios apresentado por Robert Alexy, conceituado como critério do "modo final de aplicação"165, Ávila propõe um modelo fulcrado em três distinções diversas (critério tripartite): i) natureza da descrição normativa; ii) natureza da justificação; iii) natureza da contribuição para a solução do problema $^{166}$.

Humberto Ávila distingue regras e princípios jurídicos da seguinte forma:

As regras são normas imediatamente descritivas, primariamente retrospectivas $e$ com pretensão de decidibilidade e abrangência, para cuja aplicação se exige a avaliação da correspondência, sempre centrada na finalidade que lhes dá suporte ou nos princípios que lhes são axiologicamente sobrejacentes, entre a construção conceitual da descrição normativa e a construção conceitual dos fatos.

Os princípios são normas imediatamente finalísticas, primariamente prospectivas e com pretensão de complementaridade e de parcialidade, para cuja aplicação se demanda uma avaliação da correlação entre o estado de coisas a ser promovido e os efeitos decorrentes da conduta havida como necessária à sua promoção ${ }^{167}$.

Já os objetivos almejados com tal classificação seriam os de: i) eliminar a classificação entre regras e princípios de forma excludente; ii) permitir ao intérprete do direito a análise sistemática e global das normas jurídicas, com a interação entre regras e princípios; iii) dotar o intérprete de um arsenal interpretativo capaz de solucionar conflitos aparentes entre regras e princípios, sem o uso do arbítrio ${ }^{168}$.

\footnotetext{
165“"Todas essas considerações demonstram que a afirmação de que as regras são aplicadas ao modo tudo ou nada só tem sentido quando todas as questões relacionadas à validade, ao sentido e à subsunção final dos fatos já estiverem superadas. Mesmo no caso de regras essas questões não são facilmente solucionadas. Isso porque a vagueza não é traço distintivo dos princípios, mas elemento comum de qualquer enunciado prescritivo, seja ele um princípio, seja ele uma regra. (...) O ponto decisivo não é, portanto, o suposto caráter absoluto das obrigações estatuídas pelas regras, mas o modo como as razões que impõem a implementação das suas consequências podem ser validamente ultrapassadas; nem a falta de consideração a aspectos concretos e individuais pelas regras, mas o modo como essa consideração deverá ser validamente fundamentada - o que é algo diverso". ÁVILA, Humberto. op. cit., p. 47-48 e 51.

${ }^{166}$ Para maior aprofundamento, confira-se: Id. Ibid., p. 78-84.

${ }^{167}$ Id. Ibid., p. 78-79.

${ }^{168}$ "O $\mathrm{O}$ modelo aqui defendido, mais do que separar as espécies normativas, visa a construir critérios intersubjetivamente controláveis para a sua aplicação, dada a constatação de que não são os princípios e as regras, em si mesmos, que definem uma boa ou má aplicação, mas os critérios que vertem sobre eles e direcionam o seu adequado funcionamento. Nesse aspecto, fica claro que o modelo ora sustentado, no caso das regras, não é nem um modelo formalista puro, que propugna a obediência incondicional às regras, sempre que os fatos previstos na sua hipótese ocorrerem, nem tampouco um modelo particularista puro, em que elas funcionam apenas como conselhos que podem, ou não, ser seguidos, conforme à valoração
} 
Com todo o respeito a Humberto Ávila, tenho que os objetivos por ele colimados com tal classificação já foram alcançados pela teoria elaborada por Alexy, com os desdobramentos de Virgílio Afonso da Silva.

Isso porque a teoria de Alexy não teve por escopo simplesmente diferenciar as regras dos princípios jurídicos, mas demonstrar as consequências jurídicas de tal distinção, em termos de maximização da eficácia dos princípios, que sempre foram entendidos como normas desprovidas de eficácia normativa. Acabar com a exclusividade das regras legais na irradiação de efeitos jurídicos, relegando os princípios a um papel secundário e desimportante. Ou seja, basicamente os mesmos objetivos de Humberto Ávila.

Quanto ao modelo proposto, prefiro o de Alexy, mais simples, objetivo e claro em termos de utilização, dando plena razão às objeções lançadas por Virgílio Afonso da Silva no tocante às críticas de Humberto Ávila ${ }^{169}$.

Finalmente, é inegável a contribuição substancial trazida por Robert Alexy na elaboração de um modelo fundamentador e racionalizador da força normativa dos princípios constitucionais, especialmente aqueles que consagram direitos humanos fundamentais (inclusive sociais), entendidos como "mandamentos de otimização", em perfeita sintonia e harmonia com os ideais pós-positivista e neoconstitucionalista.

\subsubsection{Dignidade da pessoa humana}

Passo, a partir de agora, a analisar outro conceito fundamental, alçado à categoria de valor norteador e orientador do próprio ideal neoconstitucionalista e dos modernos modelos de Estado Constitucional ${ }^{170}$, transformado pelo pós-positivismo em fundamento

\footnotetext{
caprichosa do aplicador. Defende-se, em vez disso, um modelo moderado e procedimentalizado, que valoriza a função e a importância das regras, sem, no entanto, afastar a sua extraordinária superação. No caso dos princípios, propugna-se por um modelo criterioso de aplicação, no qual os princípios têm funções específicas que não afastam pura e simplesmente as regras eventualmente aplicáveis. $O$ essencial é que, mesmo havendo ponderação, ela deverá indicar os princípios objeto de ponderação (pré-ponderação), efetuar a ponderação (ponderação) e fundamentar a ponderação feita. (...) As considerações precedentes demonstram, pois, que o problema da aplicação do Direito não está apenas em analiticamente separar as espécies normativas, mas em municiar o aplicador de critérios, intersubjetivamente aplicáveis, que possam tornar efetivos os comandos normativos sem a incorporação do arbítrio". ÁVILA, Humberto. op. cit., p. 121-122.

${ }^{169}$ Confira-se as críticas lançadas por Virgílio Afonso da Silva em: Direitos fundamentais: conteúdo essencial, restrições e eficácia, cit., p. 56-64.

${ }^{170}$ Confira-se o artigo $1^{\circ}$, inciso III, da Constituição: “A República Federativa do Brasil, formada pela união indissolúvel dos Estados e Municípios e do Distrito Federal, constitui-se em Estado Democrático de Direito e tem como fundamentos: (...) a dignidade da pessoa humana".
} 
de validade maior da eficácia dos princípios consagradores de direitos humanos fundamentais sociais: o princípio da dignidade da pessoa humana ${ }^{171}$.

A ideia da necessidade de se garantir dignidade aos seres humanos é trazida desde a Antiguidade, em um processo de lenta evolução que ainda hoje não chegou a uma formulação conceitual pronta e acabada ${ }^{172}$.

Não obstante, dois foram os grandes movimentos influenciadores do surgimento e desenvolvimento do conceito de dignidade humana: i) os inúmeros processos de lutas pelo reconhecimento da pessoa humana como sujeito de direitos; ii) o cristianismo, com seu ideal do homem alçado à imagem e semelhança de Deus (imago Dei), como criatura especial na Terra.

Verifica-se aqui, de forma cristalina, a grande contribuição dada pela corrente da Teoria Crítica intitulada "Escola de Frankfurt” (já estudada no capítulo 1) na explicação do fenômeno da dignidade da pessoa humana, demonstrando que as constantes lutas pelo reconhecimento travadas por diversos grupamentos humanos, ao lado da evolução do ideal cristão do imago Dei até se chegar à doutrina social da Igreja, fizeram com que o ideal de dignidade da pessoa humana deixasse o campo teórico e passasse a ser visto como princípio basilar, norteador e fundante dos direitos humanos fundamentais e dos próprios Estados Soberanos ${ }^{173}$.

\footnotetext{
${ }^{171}$ Tão relevante é o papel do princípio da dignidade da pessoa humana como fundante e protetor dos direitos humanos fundamentais que alguns autores defendem sua dupla natureza normativa estrutural (regra e princípio), como é o caso de Robert Alexy: "Por isso, é necessário que se pressuponha a existência de duas normas da dignidade humana: uma regra da dignidade humana e um princípio da dignidade humana. A relação de preferência do princípio da dignidade humana em face de outros princípios determina o conteúdo da regra da dignidade humana. Não é o princípio que é absoluto, mas a regra, a qual, em razão de sua abertura semântica, não necessita de limitação em face de alguma possível relação de preferência." ALEXY, Robert. Teoria dos direitos fundamentais, cit., p. 113-114.

${ }^{172}$ Para um apanhado acerca da evolução histórica do conceito de dignidade da pessoa humana, desde a Antiguidade até Kant, confiram-se: i) SARLET, Ingo Wolfgang. Dignidade da pessoa humana e direitos fundamentais na Constituição Federal de 1988. 5. ed. Porto Alegre: Livr. do Advogado, 2007. p. 29-39; ii) BARROSO, Luís Roberto. A dignidade da pessoa humana no direito constitucional contemporâneo. Belo Horizonte: Fórum, 2012. p. 13-19.

${ }^{173} \mathrm{~A}$ identificação do surgimento e da evolução do conceito de dignidade da pessoa humana com o processo de lutas pelo reconhecimento do homem como sujeito de direitos, e como tal ligação faz com que a história da dignidade da pessoa humana se identifique de forma umbilical com a própria história do surgimento e da evolução dos direitos humanos fundamentais é feita de forma magistral por Jürgen Habermas: "Ao contrário da suposição de uma conotação moral retrospectiva do conceito de direitos humanos com a noção de dignidade humana, gostaria de defender a tese da existência, desde o início, de um estrito nexo concetual entre os dois conceitos, embora inicialmente apenas implícito. Os direitos humanos sempre resultaram, antes de mais, da resistência à arbitrariedade, à opressão e à humilhação. Hoje, ninguém pode mencionar um destes artigos respeitáveis - por exemplo, a frase: $<$ Ninguém será submetido a tortura nem a penas ou tratamentos cruéis, desumanos ou degradantes> (Declaração Universal dos Direitos Humanos, artigo $5^{\circ}$ ) sem ouvir o eco destas palavras: o grito de inúmeras criaturas humanas que foram martirizadas e assassinadas. A invocação dos direitos humanos alimenta-se da indignação dos ofendidos face à violação
} 
Trata-se de um conceito libertador do ser humano, responsável pela sua passagem de objeto para sujeito de direito, ou seja, para o centro dos ordenamentos jurídicos estatais.

Não é sem razão que as doutrinas nacional e internacional indicam, de forma quase unânime, que o conceito de dignidade da pessoa humana tem em Kant seu principal inspirador $^{174}{ }^{175}$, através do imperativo categórico do homem como fim em si mesmo, e não meio (objeto) para a consecução de algo ${ }^{176}$.

Ademais, o conceito de dignidade da pessoa humana foi pedra angular do movimento abolicionista, bem como dos processos de lutas pelo reconhecimento e positivação das diversas dimensões dos direitos humanos fundamentais, dentro da lógica da sacralização da pessoa humana como sujeito de direitos, também fruto dos aprendizados adquiridos com histórias traumatizantes de violência vividas por grupos sociais ${ }^{177}$.

da sua dignidade humana. Se isto está no início, deverá ser possível mostrar a existência deste nexo concetual também na própria evolução do direito". HABERMAS, Jürgen. Um ensaio sobre a Constituição da Europa, cit., p. 30-31.

${ }^{174}$ Para maior aprofundamento, confira-se: BARROSO, Luís Roberto. A dignidade da pessoa humana no direito constitucional contemporâneo, cit., p. 68-72.

${ }^{175}$ Não obstante a adoção do pensamento kantiano neste trabalho, pelo qual deixo clara a minha opção - aliás, o que já tenho feito desde o primeiro capítulo desta obra - pelo enfoque universalizante dos direitos humanos fundamentais, inclusive, no tocante ao princípio fundante da dignidade da pessoa humana, é certo que existem autores de peso defensores de uma visão diferente para a dignidade da pessoa humana. Faço referência expressa a Hegel, cujo enfoque filosófico é mais centrado no Estado do que no indivíduo - não obstante sua maior contribuição filosófica tenha sido a distinção entre espaço público (estatal) e espaço da sociedade civil (coletivo não estatal) - pelo que seu conceito de dignidade da pessoa humana não é dado como elemento ontológico do ser humano, mas sim uma qualidade a ser conquistada por meio da assunção do papel de cidadão pela pessoa. A propósito, confira-se SARLET, Ingo Wolfgang. Dignidade da pessoa humana e direitos fundamentais na Constituição Federal de 1988, cit., p. 36-38.

${ }^{176}$ Tal constatação é feita, de forma cabal, por Ana Paula de Barcellos: "Um dos poucos consensos teóricos do mundo contemporâneo diz respeito ao valor essencial do ser humano. Ainda que tal consenso se restrinja muitas vezes apenas ao discurso ou que essa expressão, por demais genérica, seja capaz de agasalhar concepções as mais diversas - eventualmente contraditórias -, o fato é que a dignidade da pessoa humana, o valor do homem como um fim em si mesmo, é hoje um axioma da civilização ocidental, e talvez a única ideologia remanescente. (...) No que mais diretamente nos interessa, e de uma forma bastante simplificada, pode-se dizer que, para Kant, o homem é um fim em si mesmo - e não uma função do Estado, da sociedade ou da nação - dispondo de uma dignidade ontológica. O Direito e o Estado, ao contrário, é que deverão estar organizados em benefício dos indivíduos. Assim é que Kant sustenta a necessidade da separação dos poderes e da generalização do princípio da legalidade como forma de assegurar aos homens a liberdade de perseguirem seus projetos individuais. Interessantemente, e nada obstante os vários retrocessos históricos, a concepção kantiana de homem continua a valer como axioma no mundo ocidental, ainda que a ela se tenham agregado novas preocupações, como a tutela coletiva dos interesses individuais e a verificação da existência de condições materiais indispensáveis para o exercício da liberdade". BARCELLOS, Ana Paula de. op. cit., p. 127-129.

${ }^{177}$ Quem bem sintetiza tal influência é Hans Joas: "Quando se parte dos textos codificados existentes para responder a pergunta pelo papel de experiências de violência na história dos direitos humanos, é possível demonstrar rapidamente a importância da evolução da violência $O$ teólogo evangélico Wolfgang Vögele, por exemplo, examinou e expôs detalhadamente a pré-história da sentença sobre a dignidade humana que consta no início da Constituição alemã. Ele mostra que o conceito de dignidade humana aparece como orientação básica para uma futura constituição tanto nos princípios do Círculo de Kreisau para a 
Atualmente, o conceito de dignidade da pessoa humana foi adotado pelo neoconstitucionalismo como um dos pilares fundantes do Estado, bem como baliza norteadora dos sistemas constitucionais ocidentais em termos de organização estatal e proteção dos direitos humanos fundamentais, sendo princípio alçado à categoria de fundamento de todos os demais direitos humanos fundamentais garantidos nas cartas constitucionais dos Estados Ocidentais ${ }^{178}$.

Já a grande influência da doutrina social da Igreja na conformação e elevação do princípio da dignidade da pessoa humana à categoria de pilar e elemento fundante dos direitos humanos fundamentais é trazida por Cleber Francisco Alves, o qual, após desenvolver o conceito de dignidade da pessoa humana para a doutrina social da Igreja, assim arremata:

\begin{abstract}
No enfoque da Doutrina Social da Igreja, ao estabelecer a dignidade da pessoa humana como fundamento do Estado brasileiro, temos que a Constituição de 1988 traça um compromisso indeclinável em favor do homem. Compromisso que deve ser assumido e estendido de maneira cada vez mais ampla para todos os segmentos da sociedade, no anseio de proporcionar a cada ser humano - seja individualmente ou inserido na comunidade, e das suas condições pessoais inatas - a oportunidade de alcançar um estágio de felicidade e bem estar físico, psíquico, emocional e espiritual nesta jornada terrena, sem fechar-lhe os horizontes para uma outra dimensão transcendental onde possa encontrar o "Absoluto", capaz de preencher o vazio infinito que existe em seu coração ${ }^{179}$.
\end{abstract}

Esses dois grandes movimentos influenciadores do surgimento e da elevação da dignidade da pessoa humana a conceito fundante das atuais ordens constitucionais estatais e de todos os direitos humanos fundamentais positivados - o cristianismo e seu ápice na doutrina social da igreja e o processo de lutas pelo reconhecimento da pessoa humana como sujeito de direitos - dão o atual caráter, inequívoco, do princípio da dignidade da pessoa humana como o ponto de contato entre direito e moral.

reordenação da Alemanha como em textos de proveniência social-democrata e democrata-cristã da primeira fase do pós-guerra". JOAS, Hans. op. cit., p. 108. Para maior aprofundamento, indico a leitura do capítulo integral, intitulado "Violência e dignidade humana: Como as experiências se convertem em direitos"; p. 105-142.

${ }^{178}$ Confira-se, a propósito: i) SARLET, Ingo Wolfgang. Dignidade da pessoa humana e direitos fundamentais na Constituição Federal de 1988, cit., p. 63-64; ii) SOARES, Ricardo Maurício Freire. $O$ princípio constitucional da dignidade da pessoa humana. São Paulo: Saraiva, 2010. p. 128; iii) BARCELLOS, Ana Paula de. op. cit., p. 164-165.

${ }^{179}$ ALVES, Cleber Francisco. O princípio constitucional da dignidade da pessoa humana: o enfoque da doutrina social da igreja. Rio de Janeiro: Renovar; 2001. p. 179. Para um conceito de dignidade da pessoa humana pela doutrina social da igreja, confira-se, na mesma obra, p. 63-65. Para uma visão da influência da Igreja Católica na construção do conceito de dignidade da pessoa humana e sua inserção na CF/88, confirase, na mesma obra, p. 157-159. 
Ou, melhor dizendo, o princípio da dignidade da pessoa humana é alçado à condição de ponte pela qual a moral ingressa no mundo jurídico, dando contornos de imperatividade aos comandos morais inseridos em dada ordem social, em certa época ${ }^{180}$.

Ademais, no atual estágio de desenvolvimento do conceito de dignidade da pessoa humana, dentro do neoconstitucionalismo, a maior parte da doutrina defende que somente dentro dos atuais Estados Democráticos e Sociais de Direito é que se pode assegurar a elevação de tal primado à categoria de fundamento dos direitos humanos fundamentais.

Ou seja, o princípio da dignidade da pessoa humana somente é alçado à categoria de elemento estruturante fundamental, introdutor e garantidor de conceitos e comandos morais e de direitos humanos fundamentais na ordem jurídica, dentro do Estado Democrático e Social de Direito, onde assume sua formatação jurídica ${ }^{181} 182$.

Observe, portanto, que todos os conceitos fundamentais até agora desenvolvidos possuem uma raiz evolutiva comum - são todas faces de uma mesma moeda -, que é exatamente a história das lutas pelo reconhecimento da pessoa humana como sujeito de direitos, altamente influenciada pelo processo de sacralização do homem, o que culmina com o reconhecimento do homem como sendo o centro dos ordenamentos jurídicos modernos (sujeito de direitos).

Tal processo, lento e gradual, passa por vários estágios de desenvolvimento e cristalização, culminando nos grandes mecanismos jurídicos de garantia e proteção do ser humano: i) o surgimento do constitucionalismo e das constituições como ápice e centro dos ordenamentos jurídicos; ii) a positivação dos direitos humanos fundamentais, necessariamente inseridos no ápice de cada ordenamento jurídico; iii) a consolidação da

\footnotetext{
${ }^{180}$ Para maior aprofundamento, confira-se: HABERMAS, Jürgen. op. cit., p. 37 e 57.

${ }^{181}$ Para uma abordagem da dignidade da pessoa humana como fundamento da ordem constitucional e dos direitos humanos fundamentais, confira-se: SARLET, Ingo Wolfgang. Dignidade da pessoa humana $e$ direitos fundamentais na Constituição Federal de 1988, cit., p. 79-121.

${ }^{182}$ Confira-se, a propósito, os ensinamentos de Jürgen Habermas: "Por isso, a dignidade humana - uma dignidade deste tipo - também requer a ancoragem num estatuto civil, isto é, a pertença a uma comunidade organizada no espaço e no tempo. Porém, agora, este estatuto deve ser igual para todos. O conceito de dignidade humana transfere o conteúdo de uma moral de igual respeito por todos para uma ordem baseada no estatuto de cidadãos que obtêm a sua autoestima do facto de serem reconhecidos por todos os outros cidadãos como sujeitos de direito iguais e exigíveis. Não é irrelevante o facto de este estatuto só poder ser estabelecido no quadro de um Estado constitucional, que nunca surge naturalmente. Pelo contrário, este Estado tem de ser criado pelos próprios cidadãos com os meios do direito positivo, assim como tem de ser protegido e desenvolvido em circunstâncias históricas que mudam. A dignidade humana, enquanto conceito jurídico moderno, associa-se ao estatuto que os cidadãos assumem na ordem política criada por eles próprios. Só é possível aos cidadãos enquanto destinatários usufruírem dos direitos que protegem a sua dignidade humana quando conseguem, em conjunto, instituir e manter uma ordem política baseada nos direitos humanos". HABERMAS, Jürgen. op. cit., p. 43-44.
} 
dignidade da pessoa humana como fundamento e pilar de todos os direitos humanos fundamentais.

Para tanto, foram desenvolvidos diversos instrumentos jurídicos asseguradores de tal relevância e proeminência - seja em termos de positivação, seja em termos de interpretação, seja em termos eficaciais, relembrando apenas alguns, abordados neste trabalho: i) a força normativa da constituição; ii) o princípio da supremacia da constituição sobre as demais normas jurídicas infraconstitucionais; iii) o princípio da unidade da constituição; iv) a força normativa dos princípios constitucionais; v) o princípio da vedação do retrocesso social; vi) o princípio do direito adquirido social; vii) a regra da aplicabilidade imediata das normas jurídicas positivadoras de direitos humanos fundamentais; viii) a inserção das normas veiculadoras e garantidoras de direitos humanos fundamentais dentre as chamadas "cláusulas pétreas".

Veja que existe um arsenal argumentativo e normativo, alocado na Lei Maior de cada Estado, assegurador dos direitos humanos fundamentais, pelo que, como corolário inarredável, deve ser extraída a afirmação de que, nas atividades de interpretação e aplicação ("concretização", segundo Konrad Hesse) de tais direitos, deve-se buscar sua máxima efetividade possível ("mandamentos de otimização", conforme expressão cunhada por Robert Alexy).

Não é sem razão que tal preocupação se encontra na base dos atuais conceitos cunhados pela doutrina para o princípio da dignidade da pessoa humana ${ }^{183}$.

Mas tais constatações não implicam, em absoluto, que o princípio da dignidade da pessoa humana, como meta-princípio, reveste-se de caráter absoluto. Antes, deve ser entendido como norte, como instrumento auxiliar na interpretação e aplicação das normas jurídicas constitucionais fixadoras de direitos humanos fundamentais.

Trata-se de princípio jurídico, dotado de grande carga eficacial, porém - dentro dos ensinamentos apresentados por Robert Alexy, com os quais concordo - como comando que deve ser concretizado dentro das máximas possibilidades fáticas e jurídicas existentes.

Seu papel central nos sistemas jurídicos modernos ocidentais fez com que grande parcela da doutrina enxergasse nele uma dupla natureza jurídica, de princípio e regra ${ }^{184}$,

\footnotetext{
${ }^{183}$ Confira-se, a propósito: i) CANOTILHO, José Joaquim Gomes. op. cit., p. 225; ii) SARLET, Ingo Wolfgang. Dignidade da pessoa humana e direitos fundamentais na Constituição Federal de 1988, cit., p. 62.; iii) BARROSO, Luís Roberto. A dignidade da pessoa humana no direito constitucional contemporâneo, cit., p. 72.

${ }^{184}$ Confiram-se, a propósito: i) ALEXY, Robert. Teoria dos direitos fundamentais, cit., p. 111-114; ii) SARLET, Ingo Wolfgang. Dignidade da pessoa humana e direitos fundamentais na Constituição Federal de 1988, cit., p. 68-77; iii) BARCELLOS, Ana Paula de. op. cit., p. 242-248.
} 
sendo que a regra jurídica extraída do primado da dignidade da pessoa humana teria um valor absoluto, impositivo perante as demais regras e princípios jurídicos: trata-se do conceito doutrinariamente construído de mínimo existencial ${ }^{185}$, que será retomado no próximo capítulo.

De minha parte, comungo das abalizadas opiniões de Luís Roberto Barroso ${ }^{186}$ e Virgílio Afonso da Silva ${ }^{187}$, para os quais, não obstante seu papel central e fundante das ordens jurídicas ocidentais modernas, a dignidade da pessoa humana possui a natureza jurídica única de princípio, logo, submetida a limites na sua aplicação concreta, de onde se extrai o tormentoso problema da reserva do possível como limite fático de aplicação, a ser abordado também no próximo capítulo.

Analisados os dois mecanismos de proteção de todos os direitos humanos fundamentais, passo, a partir de agora, ao estudo de dois instrumentos garantidores especificamente dos direitos humanos fundamentais sociais, a saber: i) a vedação do retrocesso social; e ii) o direito adquirido social.

\footnotetext{
${ }^{185}$ Obra de referência sobre o tema, que merece leitura para maior aprofundamento, é a seguinte: TORRES, Ricardo Lobo. O direito ao mínimo existencial. Rio de Janeiro: Renovar, 2009.

186“'A dignidade humana, portanto, é um valor fundamental, mas não deve ser tomada como absoluta. Valores, sejam políticos ou morais, adentram o mundo do direito usualmente assumindo a forma de princípios. E embora direitos constitucionais e princípios constitucionais frequentemente se justaponham, esse não é exatamente o caso aqui. A melhor maneira de classificar a dignidade humana é como um princípio jurídico com status constitucional, e não como um direito autônomo, como será demonstrado abaixo." BARROSO, Luís Roberto. A dignidade da pessoa humana no direito constitucional contemporâneo, cit., p. 64. Confira-se, outrossim, da mesma obra, o início do Capítulo 2, que trata da "Dignidade Humana como um Princípio Jurídico", p. 61-68.

187،"Embora a ideia subjacente à proposta de Alexy seja defensável - ou seja, garantir uma barreira intransponível no direito que muitos consideram, com boas razões, como o direito que fundamenta todos os outros -, os problemas dessa proposta não são poucos. Ao contrário, todos os problemas vistos acima, quando se analisou a relação da dignidade com as teorias absolutas, valem aqui, também. Mais que isso: todos os problemas relacionados à definição do que deve fazer parte desse conteúdo absoluto, que, de uma certa forma, são semelhantes aos déficits de fundamentação da teoria interna, vistos no capítulo anterior, vêm, aqui, de novo à tona. Para evitar todos esses problemas e, além disso, manter a coerência com os pressupostos deste trabalho, parece-me possível sustentar que também a dignidade segue os mesmos caminhos de todos os princípios, e, portanto, tende a ter um conteúdo essencial relativo, a não ser nos casos em que a própria constituição, em normas com estrutura de regra, defina condutas absolutamente vedadas nesse âmbito. A principal delas seria, sem dúvida alguma, a vedação de tortura e tratamento degradante (art. $5^{\circ}$, III), que impõe uma barreira intransponível - ou seja, imune a relativizações a partir de sopesamentos - no conteúdo essencial da dignidade da pessoa humana. Com isso, torna-se possível uma proteção efetiva e, em vários casos, absoluta da dignidade sem que seja necessário recorrer a exceções $a d$ hoc ao modelo desenvolvido." SILVA, Virgílio Afonso da. op. cit., p. 201-202. Para um maior aprofundamento acerca da celeuma doutrinária existente entre os defensores da existência de um conceito de dignidade da pessoa humana como regra versus como princípio, inserido dentro da ideia de conteúdo essencial dos direitos fundamentais $($ absoluto $=$ regra versus relativo $=$ princípio $)$, leia, na mesma obra, p. 183-207.
} 


\subsubsection{Vedação do retrocesso social}

Inicio com o estudo do princípio da vedação do retrocesso social, cujas origens remontam à doutrina alemã $\tilde{n}^{188}$.

Com efeito. Sendo certo que o sistema constitucional alemão não garante expressamente direitos humanos fundamentais sociais em espécie, os quais são derivados dos princípios gerais do Estado Social ${ }^{189}$ e da dignidade da pessoa humana, não é possível se assegurar àqueles direitos, ao menos em princípio, o caráter de direitos subjetivos.

Em assim sendo, a doutrina alemã acabou desenvolvendo mecanismos de garantia e de ampliação da eficácia dos direitos humanos fundamentais sociais, dentre os quais ganhou relevo o princípio da vedação do retrocesso social, direcionado ao legislador infraconstitucional, e que tem por âmbito de atuação a vedação de supressão pura e simples de normas jurídicas garantidoras de direitos humanos fundamentais sociais.

Não é que se impeça pura e simplesmente a revogação pelo legislador ordinário de quaisquer normas jurídicas asseguradoras de direitos humanos fundamentais sociais: exigese, para tanto, a existência de fundamento constitucional, bem como a adoção de outros mecanismos de garantia de tais direitos sociais.

Ou seja, o legislador ordinário pode modificar as políticas públicas voltadas à concretização dos direitos humanos fundamentais sociais, fixando novos limites e contornos, desde que com supedâneo constitucional. O que fica vedado é a supressão pura e simples de tais normas jurídicas.

É fácil perceber como o princípio da vedação do retrocesso social está inserido, de forma implícita, na função negativa dos direitos humanos fundamentais sociais (=direitos de defesa $)^{190}$, como vedação dirigida ao Estado de supressão de direitos já consagrados e normatizados $^{191}$.

\footnotetext{
${ }^{188}$ Para um apanhado geral do princípio da vedação do retrocesso social na doutrina estrangeira, e sua origem alemã, confira-se: DERBLI, Felipe. O princípio da proibição de retrocesso social na Constituição de 1988. 1. ed. Rio de Janeiro: Renovar, 2007. p. 135-197.

${ }^{189}$ Confira-se, a propósito: HESSE, Konrad. Elementos de direito constitucional da República Federal da Alemanha, cit., p. 169-177.

${ }^{190}$ Confira-se, a propósito: Id. Ibid., p. 235.

${ }^{191}$ Confira-se escólio de José Joaquim Gomes Canotilho sobre o tema: “O princípio da proibição de retrocesso social pode formular-se assim: o núcleo essencial dos direitos sociais já realizado e efectivado através de medidas legislativas ('lei da segurança social', 'lei do subsídio de desemprego', 'lei do serviço de saúde') deve considerar-se constitucionalmente garantido, sendo inconstitucionais quaisquer medidas estaduais que, sem a criação de outros esquemas alternativos ou compensatórios, se traduzam, na prática, numa 'anulação', 'revogação' ou 'aniquilação' pura a simples desse núcleo essencial. Não se trata, pois, de
} 
O conceito trazido por Canotilho expõe todos os fundamentos necessários à inserção da vedação do retrocesso social como princípio implícito da constituição alemã, a saber: i) o princípio do Estado Social; ii) a dignidade da pessoa humana; iii) a proteção do núcleo essencial dos direitos humanos fundamentais sociais.

Ademais, pelo conceito formulado fica claro que a vedação do retrocesso social possui natureza jurídica de princípio constitucional, cujo âmbito de aplicação se restringe aos casos de tentativa pura e simples de supressão legislativa de políticas públicas concretizadoras de direitos humanos fundamentais sociais mediante a adoção de diplomas normativos infraconstitucionais.

Tal conceito não se aplica aos casos de omissão inconstitucional na implementação de tais direitos humanos fundamentais sociais pela via legislativa, os quais devem ser submetidos ao crivo do Poder Judiciário pela via do controle jurisdicional da inconstitucionalidade por omissão.

De qualquer forma, é certo que o conceito cunhado pela doutrina alemã à vedação do retrocesso social, bem como sua natureza jurídica de princípio constitucional ${ }^{192}$, foram importados de forma integral pela doutrina pátria ${ }^{193}$.

Quanto aos fundamentos constitucionais para a adoção do princípio constitucional implícito da vedação do retrocesso social em nosso país, além daqueles três já mencionados pela doutrina alemã (Estado Social, dignidade da pessoa humana e núcleo essencial), somam-se os seguintes: i) princípio da máxima e imediata eficácia e efetividade das normas definidoras de direitos humanos fundamentais sociais (art. $5^{\circ}, \S 1^{\mathrm{o}}$, da Constituição); ii) os vários mecanismos constitucionais de proteção contra medidas de cunho retroativo, fundamentadas no pilar constitucional da segurança jurídica; iii)

proibir um retrocesso social captado em termos ideológicos ou formulado em termos gerais ou de garantir em abstracto um status quo social, mas de proteger direitos fundamentais sociais sobretudo no seu núcleo essencial. A liberdade de conformação do legislador e inerente auto-reversibilidade têm como limite o núcleo essencial já realizado, sobretudo quando o núcleo essencial se reconduz à garantia do mínimo de existência condigna inerente ao respeito pela dignidade da pessoa humana (cf. Ac. 509/2002, DR, I 12/2/2003)". CANOTILHO, José Joaquim Gomes. op. cit., p. 339-340.

${ }^{192}$ Para maior aprofundamento sobre o conceito, fundamentos e natureza jurídica do princípio constitucional implícito à vedação do retrocesso social, confiram-se: i) DERBLI, Felipe. op. cit., p. 199-299; ii) SAMPAIO, Marcos. O conteúdo essencial dos direitos sociais. São Paulo: Saraiva, 2013. p. 229-234; iii) OLIVEIRA, Márcio Luís de. op. cit., p. 271-275; iv) FIRMINO, Nelson Flávio. op. cit., p. 279-289.

${ }^{193}$ Confiram-se, a propósito, conceitos trazidos por doutrinadores pátrios de peso, tais como: i) SARLET, Ingo Wolfgang. A eficácia dos direitos fundamentais, cit., p. 456-457; ii) BARCELLOS, Ana Paula de. op. cit., p. 87; iii) BITENCOURT NETO, Eurico. O direito ao mínimo para uma existência digna. Porto Alegre: Livr. do Advogado, 2010. p. 162-163. 
princípio da proteção da confiança ${ }^{194}$; iv) princípio da supremacia da constituição e do consequente corolário da vinculação do legislador ordinário aos comandos constitucionais; v) inserção dos direitos humanos fundamentais, inclusive sociais, como "cláusulas pétreas"; vi) imposição aos Estados, pelo sistema internacional de proteção aos direitos humanos fundamentais sociais, de paulatina e contínua implementação e concretização de tais direitos 195196 .

De todo o exposto, verifica-se que a vedação do retrocesso social configura princípio constitucional implícito voltado à proteção dos direitos humanos fundamentais sociais já positivados e implementados em nível infraconstitucional, configurando barreira ao legislador ordinário a exigir um ônus argumentativo no sentido de somente autorizar a revogação de legislação disciplinadora de tais direitos quando existente fundamento constitucional de relevo e em seu lugar seja adotada nova disciplina jurídica, também asseguradora dos mesmos direitos humanos fundamentais sociais.

Como princípio, não possui valor absoluto, correspondendo a um mandamento de otimização, voltado à criação de uma barreira assecuratória do núcleo essencial dos direitos humanos fundamentais sociais garantidos pela ordem constitucional de dado país e já implementados pelo parlamento via edição de leis ordinárias.

Em razão da adoção pessoal do mesmo entendimento comungado por Virgílio Afonso da Silva, no sentido de que todos os direitos humanos fundamentais possuem suporte fático amplo e núcleo essencial relativo, o que ocorre na prática com o princípio da vedação do retrocesso social é a imposição, ao legislador ordinário, do ônus argumentativo de demonstrar a existência de princípio constitucional mais relevante para

\footnotetext{
${ }^{194}$ O princípio da proteção da confiança foi introduzido no Brasil por Canotilho: "Em geral, considera-se que (...) a protecção da confiança se prende mais com as componentes subjectivas da segurança, designadamente a calculabilidade e previsibilidade dos indivíduos em relação aos efeitos jurídicos dos actos dos poderes públicos. A segurança e a protecção da confiança exigem, no fundo: (1) fiabilidade, clareza, racionalidade e transparência dos actos do poder; (2) de forma que em relação a eles o cidadão veja garantida a segurança nas suas disposições pessoais e nos efeitos jurídicos dos seus próprios actos." CANOTILHO, José Joaquim Gomes. op. cit., p. 257.

${ }^{195}$ Para maior aprofundamento sobre a imperiosidade da implementação paulatina e contínua dos direitos humanos fundamentais sociais pelos Estados aderentes ao Pacto Internacional dos Direitos Econômicos, Sociais e Culturais, confira-se: PIOVESAN, Flávia. Direitos humanos e o direito constitucional internacional, cit., p. 174-183.

${ }^{196}$ Para um melhor apanhado acerca dos fundamentos constitucionais do princípio da vedação do retrocesso social no Brasil, confira-se: SARLET, Ingo Wolfgang. A eficácia dos direitos fundamentais, cit., p. 457-460.
} 
a supressão de dada disciplina jurídica legal, com a inserção de outra disciplina em seu lugar, passível de controle judicial pela via do critério da proporcionalidade ${ }^{197} 198$.

Em arremate, observo que existem críticas doutrinárias de peso contrárias à adoção do princípio da vedação do retrocesso social ${ }^{199}$, notadamente levando em conta que se trata de criação da doutrina alemã, cujo modelo constitucional não prevê direitos humanos fundamentais específicos, ao contrário de sistemas como o português e o brasileiro, dotados de extensos róis garantidores de inúmeros direitos humanos fundamentais sociais, inseridos dentro de um regime jurídico constitucional único ${ }^{200}$.

De minha parte, não obstante reconheça que a teoria dos limites às restrições dos direitos humanos fundamentais é suficiente e idônea para resolver o problema da supressão de normas jurídicas disciplinadoras de direitos humanos fundamentais sociais pelo

\footnotetext{
${ }^{197}$ SILVA, Virgílio Afonso da. op. cit., p. 253-254.

${ }^{198}$ Interessante critério de controle da atividade legislativa revogadora de normas jurídicas disciplinadoras de direitos humanos fundamentais sociais pela via da vedação do retrocesso social é apresentado por Ana Paula de Barcellos: "Imagine-se o texto constitucional originalmente editado, e o direito fundamental por ele previsto, antes de qualquer regulamentação. Imagine-se agora a nova regulamentação pretendida para o direito: a que se encontra sob suspeita de restringir invalidamente a disciplina anterior. $\mathrm{O}$ teste que se propõe envolve o confronto da nova regulamentação com o texto constitucional diretamente, e não com a regulamentação porventura anteriormente existente. $\mathrm{O}$ teste é guiado pela seguinte questão: a nova disciplina pretendida é compatível com a garantia constitucional, tendo em conta o sentido em que ela é compreendida contemporaneamente? Ou, dito de outro modo: a nova regulamentação realiza de forma minimamente adequada o bem jurídico tutelado pelo direito fundamental constitucionalmente previsto? A regulamentação pretendida garante a aplicabilidade real e efetiva - isto é: a fruição por seus destinatários do direito constitucional? Se as respostas a tais perguntas puderem ser afirmativas, a nova regulamentação não poderá ser considerada inválida e a vedação do retrocesso não será aplicável. Se alguma dessas respostas, porém, for negativa, a invalidade parece ser a consequência natural para o caso". BARCELLOS, Ana Paula de. A eficácia jurídica dos princípios constitucionais: o princípio da dignidade da pessoa humana, cit., p. 92-93.

${ }^{199}$ Ácida crítica é apresentada no raciocínio de Jorge Reis Novais: "Com efeito, basta considerar o elenco de princípios ou critérios a que a concepção da proibição relativa recorre para limitar o legislador que retrocede, para imediatamente se perceber que se tratará, pura e simplesmente, dos chamados limites aos limites dos direitos fundamentais, ou seja, dos limites constitucionais, próprios de Estado de Direito, que os poderes públicos têm de observar quando restringem os direitos fundamentais. Da observância dos limites aos limites depende a legitimidade constitucional da restrição, exactamente da mesma forma que da sua observância dependeria, segundo os defensores da proibição relativa, a legitimidade constitucional do dito retrocesso. Pergunta-se, então - e aquilo que surpreende é tanto a ausência da resposta quanto da pergunta - porquê, pura e simplesmente, não tratar o retrocesso por aquilo que, na realidade, é, ou seja, restrição a direito fundamental, legítima ou ilegítima consoante se observam ou se desrespeitam os limites constitucionais das restrições aos direitos fundamentais? Porquê não resolver o aparentemente inextricado problema da defesa dos direitos sociais tão somente recorrendo à teoria das restrições aos direitos fundamentais, desenvolvida, testada e utilizada generalizadamente em Estado de Direito há mais de cinquenta anos?" NOVAIS, Jorge Reis. op. cit., p. 246-247.

200“"Trata-se, portanto, de uma invenção alemã, naturalmente aplicável em contextos jurídicos semelhantes, mas totalmente improdutiva, redundante e obscurecedora em contextos constitucionais em que os direitos sociais são direitos fundamentais. Logo, se o são, que razões podem explicar que, em caso da sua afectação negativa por acções do poder público, não se lhes aplique o padrão de controlo próprio de Estado de Direito, ou seja, o padrão do controlo das restrições aos direitos fundamentais? Com efeito, nada permite explicar essa recusa a não ser a pré-compreensão, o pré-conceito ou a simples tendência para a importação, neste caso acrítica e injustificada, dos produtos alemães.” Id. Ibid., p. 247.
} 
legislador ordinário - há pouco reconheci a adoção do modelo proposto por Virgílio Afonso da Silva -, bem como reconheça que os mecanismos de controle adotados pelos defensores do princípio da vedação do retrocesso social são os mesmos adotados para controle dos limites às restrições dos direitos humanos fundamentais, baseio a utilidade da fixação e manutenção de tal princípio constitucional implícito no fato de que tais supressões normativas representam um plus, um grau maior de violação aos direitos humanos fundamentais sociais.

É que não se está falando de simples restrição a direito humano fundamental social pontual, mas em controle de iniciativas legislativas de supressão de toda uma disciplina jurídica voltada à concretização de direitos humanos fundamentais sociais garantidos constitucionalmente.

Para tal controle, parece-me que o princípio da vedação do retrocesso social tem a utilidade de oferecer um método objetivo e efetivo de controle, de fácil aferição, com a evidente vantagem de seu caráter educativo e instrutivo.

O princípio da vedação do retrocesso social constitui, pois, um método mais específico de controle do que aquele fixado para controle dos limites às restrições de direitos humanos fundamentais, voltado ao controle específico de supressão, pelo Legislativo, de normas jurídicas disciplinadoras de direitos humanos fundamentais sociais.

Para as demais modalidades de restrição a direitos humanos fundamentais, aplica-se o método geral do controle dos limites a tais restrições.

\subsubsection{Direito adquirido social}

Por fim, analiso o mecanismo do direito adquirido social.

Trata-se de evolução da visão clássica do direito adquirido, como garantia individual do cidadão em face do Estado - direito humano fundamental de primeira dimensão, de matriz liberal.

Assim é que, dentro do modelo de Estado Liberal, com o surgimento da primeira dimensão de direitos humanos fundamentais, instituiu-se uma garantia qualificada do cidadão em face do Estado, voltada à sua segurança jurídica, de modo que os direitos 
previstos em lei e cujos requisitos fossem todos cumpridos pelo particular não poderiam mais ser negados ou restringidos pelo Estado.

Essa é a visão clássica do direito adquirido, surgida no âmbito do Direito Civil, de cunho eminentemente patrimonial e cujo maior expoente foi Francesco Gabba.

Trata-se de visão até hoje sufragada pela doutrina ${ }^{201}$ e pela jurisprudência do Supremo Tribunal Federal, inclusive na esfera dos direitos sociais, com base na máxima de que "não existe direito adquirido a regime jurídico"202.

Em termos de positivação, emblemático é o caso brasileiro, onde o primeiro diploma normativo garantidor do direito adquirido foi o Decreto-lei n. 4.657/42 (art. 6º caput), antiga Lei de Introdução ao Código Civil - rebatizada pela Lei n. 12.376/10 de "Lei de Introdução às Normas do Direito Brasileiro”. Ou seja, trata-se de garantia inicialmente vinculada unicamente ao regime de direito privado, em favor dos particulares em face de outros particulares e do próprio Estado.

Não obstante, com o pós-positivismo e o neoconstitucionalismo, o modelo de Estado Liberal é substituído pelo modelo de Estado Social Democrático de Direito, com a incorporação dos direitos humanos fundamentais às constituições nacionais, inclusive, direitos fundamentais sociais, todos sob o influxo do metaprincípio norteador da dignidade da pessoa humana.

A partir desse novo cenário, o conceito de direito adquirido deixa de ter aplicação unicamente sob o enfoque dos direitos de liberdade do particular em face do Estado (direitos negativos), passando a abranger também as novas dimensões de direitos humanos fundamentais, notadamente os sociais (direitos positivos, prestacionais), em um enfoque

\footnotetext{
201“Já de início há que se fazer constar que o estudo do direito adquirido vem sendo feito por estudiosos a partir de uma análise geralmente individualista do fenômeno - isto se dá especialmente pelo fato de que a questão tem sido, em grande parte, analisada sob a perspectiva do direito civil e da teoria geral do direito (que, no nosso entender, vem sendo tratada como teoria geral especificamente do direito privado). Percebese que a maioria dos juristas parte da teoria exposta por Gabba em 1884 (na sua famosa obra Teoria della retroattività delle legi, 2. ed., Torino: UTET, v. I). O conceito proposto por este autor vem sendo o parâmetro, com algumas poucas ressalvas, admitido pela doutrina pátria”. CORREIA, Marcus Orione Gonçalves; CORREIA, Érica Paula Barcha. Curso de direito da seguridade social. 6. ed. São Paulo: Saraiva, 2012. p. 91-92.

${ }^{202}$ Confira-se, dentre inúmeros outros precedentes, os seguintes, que versam sobre direitos sociais, notadamente direito previdenciário: AI 803861 AgR/RS, Rel. Min. ROSA WEBER; RE 626489/SE, Rel. Min. ROBERTO BARROSO; RE 671628 AgR/PR, Rel. Min. LUIZ FUX.
} 
não mais exclusivamente individualizado, mas também coletivo, qual seja, de toda a coletividade em face do Estado ${ }^{203}$.

Do exposto, se o conceito clássico de direito adquirido é aquele individualpatrimonialista de Francesco Gabba, o conceito atual e constitucional (art. 5º XXXVI, da Constituição) de direito adquirido, dentro do pós-positivismo e do neoconstitucionalismo, passa também por uma visão coletiva, da sociedade frente ao Estado.

Assim, o direito adquirido passa de uma garantia do cidadão de não interferência estatal em sua esfera patrimonial de direitos ${ }^{204}$ para uma verdadeira garantia das conquistas civilizatórias adquiridas pela sociedade como um todo até certa etapa da evolução social.

Evidente a ampliação de sentido e alcance do conceito de direito adquirido dentro desse novo modelo de Estado, já que a própria condição de direito adquirido passa a vedar ao Estado a supressão ou diminuição de direitos até então previstos e implementados em favor da coletividade ${ }^{205}$.

${ }^{203}$ Tal evolução restou muito bem explicitada por Marcus Orione Gonçalves Correia e Érica Paula Barcha Correia: "Sob a perspectiva acima, a visão do direito adquirido do século XIX, obviamente, não deve ser aquela que deve permear o fenômeno para o século XXI. (...) Ressalte-se, portanto, que o conceito e a dimensão constitucionais do direito adquirido devem-se fazer suficientes para a aplicação indistinta em quaisquer ramos do direito - não apenas valendo para situações referentes ao direito civil, mas também ramos do direito essencialmente ligados aos direitos sociais, tais como o direito do trabalho ou o direito da segurança social (previdência, assistência e saúde, nos moldes do art. 194 da CF). Estamos no âmbito do direito adquirido e não apenas do direito civil adquirido ou do direito do trabalho adquirido. (...) Assim, das observações anteriores resta claro que o direito adquirido, enquanto decorrente de princípio constitucional, encontra-se adstrito, na sua análise constitucional, ao postulado da dignidade humana (art. $1^{\circ}$, III, da CF). Por outro lado, deve-se entender a dignidade humana a partir da perspectiva de unidade que permeou a edificação do texto constitucional de 1988 - em especial da ideia de democracia”. CORREIA, Marcus Orione Gonçalves; CORREIA, Érica Paula Barcha. op. cit., p. 96-98.

204، Adquirido é todo direito que resultante de um fato capaz de produzi-lo segundo a lei em vigor ao tempo em que este fato se verificou: embora a ocasião de fazê-lo valer se não haja apresentado antes da atuação de uma lei nova sobre o mesmo direito; direito este que, de conformidade com a lei sob a qual aquele fato foi praticado, passou, imediatamente, a pertencer ao patrimônio de quem adquiriu." Conceito de direito adquirido de Francesco Gabba extraído da obra de: FIRMINO, Nelson Flávio. op. cit., p. 69.

${ }^{205}$ Tal ampliação no conteúdo e alcance do conceito de direito adquirido na hodierna ordem constitucional restou captada de forma precisa por Marcus Orione Gonçalves Correia e Érica Paula Barcha Correia: "Nesta linha, o direito adquirido não é apenas aquele que incorporou ao patrimônio jurídico do seu titular, em vista da incidência da norma aplicável à época do fato (o que se passa a denominar direito adquirido individual). Deve ser considerado, também, a partir da perspectiva da sociedade, como tudo o que incorporou o patrimônio jurídico desta, em vista da luta diária pela aquisição de seus direitos (o que se chama, neste estudo, de direito adquirido social - termo herdado de Anníbal Fernandes). Nesta última modalidade, ingressam em especial os direitos fundamentais (quer os individuais, quer os sociais). Assim, estamos aqui tratando muito mais do que do princípio do não retrocesso social, defendido por J.J. Gomes Canotilho, que frisa que a ideia expressa a partir deste 'tem sido designada como proibição de 'contrarrevolução social' ou de 'evolução reaccionária'. Com isto quer dizer-se que os direitos sociais e económicos (ex.: direitos dos trabalhadores, direito à assistência, direito à educação), uma vez obtido um determinado grau de realização, passam a constituir, simultaneamente, uma garantia institucional e um direito subjectivo'. Na verdade, muito mais do que apenas os direitos sociais, todos os direitos 
Trata-se, pois, de um reforço ao princípio da vedação do retrocesso social, abrangendo todas as funções estatais, e não apenas a legislativa, de modo a assegurar à sociedade a manutenção das conquistas civilizatórias já alcançadas.

Ademais, o direito adquirido social representa garantia não somente em face do legislador ordinário, mas, também em face do poder constituinte reformador, que não pode suprimir ou diminuir direitos já assegurados à sociedade ${ }^{206}$.

Analisados os principais mecanismos criados pelo neoconstitucionalismo em prol da garantia e eficácia dos direitos humanos fundamentais - inclusive sociais - focarei, no próximo capítulo, em como tal evolução deve ser entendida dentro do campo da solução jurisdicional de controvérsias.

Trata-se do tormentoso problema da sindicabilidade (ou não) dos direitos humanos fundamentais sociais, e saber quais os seus limites e contornos, o que será estudado no próximo capítulo.

fundamentais que incorporaram o patrimônio jurídico de certo povo, como conquista civilizatória inconteste deste, devem ser preservados no plano constitucional". CORREIA, Marcus Orione Gonçalves; CORREIA, Érica Paula Barcha. op. cit., p. 100-101.

${ }^{206}$ Tal é o escólio de Nelson Flávio Firmino: "De se considerar, no entanto, que, à luz da concepção teórica em que se estrutura o sistema jurídico de proteção do direito adquirido e levando em conta a evolução constitucional brasileira, o nosso constitucionalismo, consoante constata Raul Machado Horta, 'ao invés de opor Constituição e direito adquirido como valores antitéticos, vem promovendo a acomodação e o convívio entre Constituição e direito adquirido, que perdura até os nossos dias'. Esta observação vem reforçar a tese dos que entendem que se deve excluir da incidência da norma constitucional derivada a parte futura dos fatos pendentes.

É o que pensamos. Nesse sentido, cite-se o posicionamento de Alexandre de Moraes, ao examinar o direito adquirido social em face da Previdência Social:

Todos os aposentados e pensionistas, portanto, possuem direito adquirido, não só em relação à existência da aposentadoria, como situação jurídica já concretizada, mas também em relação aos valores e regras de atualização dos proventos recebidos, regidos pela Constituição e legislação atuais, inatacáveis por meio de proposta de emenda constitucional, uma vez que, nas palavras de Limongi França, 'a diferença entre expectativa de direito e direito adquirido está na existência, em relação a este, de fato aquisitivo específico já configurado por completo'. Igualmente, aqueles que preencheram todos os requisitos exigidos para a aposentadoria, na vigência da Constituição Federal e legislação atuais, porém continuam a exercer suas funções, têm a garantia do direito adquirido, não só, repetimos, em relação à aquisição da aposentadoria, como também de que seus proventos da inatividade regular-se-ão pela legislação vigente ao tempo em que reuniram os requisitos necessários FIRMINO, Nelson Flávio. op. cit., p. 71. 


\section{DIREITOS SOCIAIS E SUA PROTEÇÃO JURISDICIONAL: DO ATIVISMO JUDICIAL E DA RESERVA DO POSSÍVEL. DO FALSO PROBLEMA DA NÃO JUSTICIABILIDADE DAS CHAMADAS "POLÍTICAS PÚBLICAS"}

\subsection{Introdução}

A partir do presente capítulo inicio uma guinada metodológica em meu estudo: se nos quatro primeiros capítulos me preocupei em sedimentar as bases teóricas dos direitos humanos fundamentais (zetética), analisando sua evolução histórica, bem como o surgimento e evolução de teorias justificadoras de sua importância, e da necessidade de sua proteção e positivação nos mais variados ordenamentos jurídicos estatais, e também no plano internacional, a partir de agora minha preocupação passa a se tornar mais dogmática.

Ou seja, a partir de agora, me preocuparei com a eficácia dos direitos humanos fundamentais positivados, notadamente os sociais, sob o prisma jurisdicional, demonstrando que, com base nos pontos de partida epistemológicos por mim adotados, que contam com grande consenso doutrinário, conclusão inarredável é a de que todos os direitos humanos fundamentais possuem equivalente carga eficacial, como verdadeiros direitos subjetivos, razão pela qual podem ser acionados junto ao Poder Judiciário, sem importar em invasão de esfera de competência das outras funções estatais (Executivo e Legislativo).

Procurei demonstrar que os direitos humanos fundamentais possuem origem histórica remota, sofrendo, porém um movimento lento e gradual de desenvolvimento em termos de abrangência e grau de relevância para as sociedades, o que somente pode ser explicado pelo viés dos longos e lentos processos de lutas pelo reconhecimento do ser humano como sujeito de direitos e da sacralização da pessoa humana.

Por decorrência, é certo que tais movimentos caminham, de forma inexorável, para a ampliação e universalização dos direitos humanos fundamentais, em relação ao número de direitos protegidos, ao grau de abrangência dos grupos humanos beneficiados e às espécies de direitos asseguradas (as diversas “dimensões”).

Para a sedimentação de tais direitos, trouxe como contributo ao tema o movimento constitucionalista, que em sua gênese traz exatamente os direitos humanos fundamentais 
como justificativa para a elevação das cartas constitucionais ao ápice dos ordenamentos jurídicos estatais, sendo que ambos os movimentos se impulsionam e se justificam, um servindo de mola propulsora ao desenvolvimento do outro, seja em termos teóricos, seja em termos práticos.

Ao fim e ao cabo, procurei demonstrar que foi a junção desses movimentos que trouxe uma verdadeira revolução em prol da humanidade, sob os aspectos histórico, político, jurídico, filosófico e social, alçando os direitos humanos fundamentais e as constituições nacionais - e mesmo no plano internacional, em um movimento relativamente recente de edição de documentos protetivos e edificadores de verdadeiras constituições supranacionais - ao centro dos principais debates teóricos da humanidade, em todos os campos sociais, a ponto de grandes filósofos como Norberto Bobbio colocarem os direitos humanos fundamentais no patamar de sinal dos tempos ${ }^{207}$.

Ademais, foi o movimento constitucionalista, em seu estágio atual de desenvolvimento teórico - neoconstitucionalismo, como vertente da filosofia póspositivista - que propiciou um verdadeiro arsenal garantidor da proteção e efetividade dos direitos humanos fundamentais, dentre os quais analisei com mais vagar: i) a força normativa da constituição; ii) a força normativa dos princípios constitucionais; iii) a elevação dos direitos humanos fundamentais à categoria de cláusulas pétreas; iv) a aplicabilidade imediata e o rol aberto de normas constitucionais fixadoras dos direitos humanos fundamentais; v) a vedação do retrocesso social; vi) o direito adquirido social.

Evidentemente que tais transformações moldaram também os diferentes formatos de Estado Nacional adotados ao longo dos últimos séculos, em uma evolução que acompanhou de perto, e como decorrência necessária, a própria evolução e transformação dos direitos humanos fundamentais e do constitucionalismo.

Assim é que, grosso modo: i) o modelo de Estado Liberal burguês foi decorrência dos direitos humanos fundamentais até então reconhecidos e positivados (direitos de

\footnotetext{
207“ $E m$ um dos meus escritos sobre os direitos do homem, eu havia exumado a ideia da história profética de Kant para indicar, com relação à importância que os direitos do homem assumiram no debate atual, um sinal dos tempos. Ao contrário da história dos historiadores, que, através de depoimentos e conjecturas, tenta conhecer o passado e, através de hipóteses no formato 'se então', faz cautelosas previsões sobre o futuro, quase sempre erradas, a história profética não prevê, mas prenuncia o futuro extraindo dos acontecimentos do tempo o evento singular, único, extraordinário, que é interpretado como um sinal particularmente demonstrativo de uma tendência da humanidade para um fim, seja ele desejado ou combatido. Eu dizia, portanto, que o debate atual cada vez mais difuso sobre os direitos do homem - a ponto de ser colocado na ordem do dia das mais respeitadas assembleias internacionais - podia ser interpretado como um 'sinal premonitório', talvez o único, de uma tendência da humanidade, para retomar a expressão kantiana, 'para melhor'.” BOBBIO, Norberto. op. cit., p. 201.
} 
liberdade) em cartas constitucionais mais enxutas; ii) o modelo de Estado Social intervencionista foi decorrência do movimento de ampliação dos direitos humanos fundamentais, com o reconhecimento dos direitos sociais e econômicos, positivados em cartas constitucionais de teor dirigente e intervencionista, exatamente como forma de implementação de tais direitos, custosos por natureza; iii) o atual modelo de Estado Social Democrático de Direito foi decorrência de novos movimentos de ampliação dos direitos humanos fundamentais, com ênfase na democracia e na educação como direitos universais, plasmados em cartas constitucionais dirigentes, intervencionistas e exaustivas.

Por evidente que as transformações e evoluções estudadas nos capítulos anteriores terão consequências inexoráveis e definitivas em sede jurisdicional, de modo que o Poder Judiciário, no formato e com as estritas funções desempenhadas no modelo liberal burguês do século XVIII, não é mais o mesmo no atual formato (Estado Social Democrático de Direito), onde o rol de direitos humanos fundamentais plasmado nas constituições e a própria importância destas dentro dos ordenamentos jurídicos estatais alcançaram níveis inimagináveis - e sequer desejados pela burguesia liberal.

É o que se verifica de forma até intuitiva nos dias atuais, com o crescente protagonismo do Poder Judiciário como poder moderador dos diversos conflitos sociais existentes dentro de cada estado soberano, sejam eles entre particulares, entre particulares e o Estado ou entre os próprios órgãos integrantes da estrutura estatal, inclusive, entre funções do Estado (Executivo, Legislativo e Judiciário).

A meu ver, a grande celeuma atual em termos de proteção jurisdicional dos direitos humanos fundamentais, notadamente os sociais, demandadores de várias e custosas ações estatais para sua implementação, não reside nos limites e contornos do Poder Judiciário como garantidor de tais direitos e controlador de sua implementação pelas demais funções do Estado (Executivo e Legislativo), mas sim na legitimação e formato que tal função estatal deve ter para fazer frente a tais exigências, dentro de um contexto - repito à exaustão - de ampliação e universalização dos direitos humanos fundamentais como fruto de lutas pelo reconhecimento da pessoa humana como sujeito de direitos e do processo de sacralização da pessoa humana.

Ou seja, como deve ser entendido e moldado o Poder Judiciário para que possa se desincumbir, com eficiência, de sua função de guarda da constituição e protetor dos direitos humanos fundamentais, notadamente os sociais. 
O cenário atual demonstra um grave descompasso entre a enorme evolução do conceito, da abrangência e fundamentação dos direitos humanos fundamentais e do constitucionalismo nos últimos dois séculos, e a relativa estagnação nos estudos acerca do Poder Judiciário, que nada mais é do que uma das clássicas funções estatais, no formato construído por Montesquieu.

Como justificar, então, que o estudo das duas outras funções estatais (Executivo e Legislativo) evoluiu de molde a acompanhar o crescimento no número de direitos humanos fundamentais, consagrados constitucionalmente, e a moldar suas funções em termos de efetivação e garantia de tais direitos, e ainda hoje se discuta a legitimidade do Poder Judiciário em promover a garantia e efetivação desses mesmos direitos, inseridos em um regime jurídico único, de envergadura constitucional e alçados à condição de cláusula pétrea?

Somente uma resposta é possível: ainda se estuda o Poder Judiciário dentro de uma visão de Estado Liberal burguês, ou seja, como se a humanidade não tivesse evoluído nestes últimos 250 anos.

Por isso mesmo este capítulo adotará inegavelmente um viés crítico acerca de conceitos clássicos moldados e adotados pela doutrina pátria dentro da ótica da proteção jurisdicional dos direitos humanos fundamentais sociais: ativismo judicial, reserva do possível, mínimo existencial, ausência de legitimidade democrática pelo Poder Judiciário para controlar políticas públicas, dentre outros.

Que fique claro desde já que neste estudo não se negará a validade de tais conceitos, alguns deles de grande relevo para o correto entendimento acerca do alcance e dos limites do Poder Judiciário como locus de efetivação de direitos humanos fundamentais sociais, mas sim se efetuará a devida crítica do viés negativo com que tais conceitos são utilizados pela doutrina, como se se tratasse de obstáculos impeditivos à sua sindicabilidade.

Diante do arsenal teórico construído nos quatro primeiros capítulos, buscarei demonstrar que, dentro do atual e vigente Estado Social Democrático de Direito inaugurado pela Constituição de 1988, não há mais espaço para tais discussões, sendo inegável a legitimidade do Poder Judiciário para fazer valer direitos humanos fundamentais sociais previstos constitucionalmente. 
O centro das discussões deve ser deslocado para outro plano: como municiar o Poder Judiciário de instrumentos eficazes para fazer valer os direitos humanos fundamentais sociais, e até que ponto é este o Poder estatal mais adequado para tratar de tais questões?

Inegável será a grande influência exercida pelo jurista português Jorge Reis Novais na abordagem a ser levada a efeito neste capítulo, até mesmo porque nossa carta constitucional de 1988 sofreu enorme influxo da carta portuguesa de 1976.

Ao final da análise, espero ter conseguido contribuir para um enfoque dos direitos humanos fundamentais, notadamente os sociais, com ênfase em sua efetividade, caminho que ainda precisa ser percorrido no atual estágio de evolução da doutrina e grande preocupação de Norberto Bobbio em seus trabalhos ${ }^{208}$.

\subsection{Direitos sociais sob o prisma restritivo das "políticas públicas": uma visão crítica}

Começo afirmando que a doutrina pátria majoritária aborda o tema da proteção jurisdicional dos direitos humanos fundamentais sociais pelo prisma das chamadas políticas públicas, tema inserido na intersecção entre o direito administrativo e o direito processual civil ${ }^{209}$ - abordagem notoriamente diversa da proposta neste trabalho e que, portanto, conduz a conclusões também diversas das que serão aqui expostas.

Tal realidade é de fácil constatação a partir de consagrada definição doutrinária de "política pública"210 cunhada por Maria Paula Dallari Bucci:

Política pública é o programa de ação governamental que resulta de um processo ou conjunto de processos juridicamente regulados - processo eleitoral, processo de planejamento, processo de governo, processo orçamentário, processo legislativo, processo administrativo, processo judicial - visando

\footnotetext{
208“Afirmei, no início, que o importante não é fundamentar os direitos do homem, mas protegê-los. Não preciso aduzir aqui que, para protegê-los, não basta proclamá-los. Falei até agora somente das várias enunciações, mais ou menos articuladas. O problema real que temos de enfrentar, contudo, é o das medidas imaginadas e imagináveis para a efetiva proteção desses direitos.” BOBBIO, Norberto. op. cit., p. 36-37.

${ }^{209}$ Para maior aprofundamento sobre o tema "políticas públicas" dentro deste enfoque administrativo/processualista, indico duas importantes coletâneas de artigos jurídicos: i) BUCCI, Maria Paula Dallari (Org.). Políticas públicas: reflexões sobre o conceito jurídico, cit.; ii) GRINOVER, Ada Pellegrini; WATANABE, Kazuo (Orgs.). O controle jurisdicional de políticas públicas. 1. ed. Rio de Janeiro: Forense, 2011.

${ }^{210}$ Outros conceitos de política pública, nesta mesma linha de concretização, no plano material, de direitos assegurados aos cidadãos frente ao Estado, com ênfase na atividade administrativa e interventiva estatal executada pelo Poder Executivo, são encontrados em: i) BITENCOURT, Caroline Müller. Controle jurisdicional de políticas públicas. Porto Alegre: Nuria Fabris, 2013. p. 44-76; ii) JORGE NETO, Nagibe de Melo. O controle jurisdicional das políticas públicas: concretizando a democracia e os direitos sociais fundamentais. Salvador: JusPODIVM, 2008. p. 51-58.
} 
coordenar os meios à disposição do Estado e as atividades privadas, para a realização de objetivos socialmente relevantes e politicamente determinados.

Como tipo ideal, a política pública deve visar a realização de objetivos definidos, expressando a seleção de prioridades, a reserva de meios necessários à sua consecução e o intervalo de tempo em que se espera o atingimento dos resultados $^{211}$. (grifado)

Fácil perceber que tal conceito de "políticas públicas" está intimamente atrelado à atividade da administração pública, de execução dos diversos comandos normativos plasmados em dado ordenamento jurídico estatal com vistas a vincular as diversas ações do Estado, em uma atividade interventiva em prol dos cidadãos - atividade concretizadora, no plano material, dos direitos assegurados.

E a função estatal por excelência, histórica e teoricamente ligada a tais atividades, é o Poder Executivo, a quem compete, de forma muito sucinta e grosso modo, a "execução das leis", conforme construção clássica de Montesquieu.

Leis essas editadas pelo Poder Legislativo, via legislador ordinário, eleito pelo voto dos cidadãos dentro da lógica democrática representativa, em que a regra da maioria configura critério objetivo claro e seguro, a ponto de ser confundida com o próprio conceito de democracia.

Como ao Poder Judiciário fica atrelada a tarefa proeminente de controlar as atividades das duas outras funções estatais em termos de adequação constitucional e legal, não podendo agir de ofício, mas somente por provocação - princípio da inércia da jurisdição, sendo talvez o maior instrumento de controle de tal função estatal -, não é de se estranhar que os estudos acerca da efetivação dos direitos humanos fundamentais sociais deem grande ênfase e proeminência às atividades legislativas e executivas, abordando o Poder Judiciário dentro de uma linha restritiva, de não intervenção sobre os programas governamentais voltados à implementação de tais direitos.

Sucede que tal viés de estudo, com todo o respeito, não observa os dois importantíssimos e imprescindíveis pontos de partida utilizados neste trabalho para a análise dos direitos humanos fundamentais: i) a evolução histórica e teórica dos direitos humanos fundamentais dentro de um contexto de lutas pelo reconhecimento do ser humano como sujeito de direitos e do processo de sacralização da pessoa humana; ii) o movimento constitucionalista, também em seu contexto evolutivo.

${ }^{211}$ BUCCI, Maria Paula Dallari. O conceito de política pública em direito. In: BUCCI, Maria Paula Dallari (Org.). Políticas públicas: reflexões sobre o conceito jurídico. São Paulo: Saraiva, 2006. 
Foi da análise conjunta desses dois movimentos histórico-teóricos que foi possível extrair a inexorável conclusão no sentido de que os direitos humanos fundamentais caminham rumo à universalização, como conquistas e garantias que se estendem a toda a humanidade, alçadas à categoria de normas jurídicas constitucionais como verdadeiros pilares dos Estados Nacionais, constituindo direitos subjetivos dotados de grande carga eficacial, protegidos por importantes mecanismos, também constitucionais.

Se assim o é, também o Poder Judiciário passa a assumir papel de protagonismo como função estatal garantidora dos direitos humanos fundamentais, inclusive os sociais, já que se trata de poder responsável pela importante função de "guarda da constituição", conforme inquestionável construção teórica clássica.

Tal constatação, aliada à noção de que as funções estatais, não obstante independentes, devam guardar relação de harmonia entre si (harmonia entre os poderes, conforme assegurado no artigo $2^{\circ}$, da Constituição), fazem com que não haja mais espaço a interpretações no sentido de que ao Poder Judiciário não caberia exercer o papel de garantidor da efetividade dos direitos humanos fundamentais sociais.

O que ocorre é que o tema "políticas públicas", ao ser estudado pelo viés administrativo-processualista, ainda caracteriza o Poder Judiciário dentro da lógica de Estado de Direito liberal-burguês, ou seja, como se o juiz ainda exercesse a função de mera “boca da lei”, para utilizar expressão consagrada cunhada por Montesquieu.

É como se ao Poder Judiciário somente competisse a realização da justiça "comutativa" ou "retributiva" "12, qual seja, a resolução de conflitos individuais entre particulares, sem o exercício de controle sobre as atividades estatais, ou acerca da garantia daquele espaço de liberdade aos cidadãos, dentro da lógica da não intervenção estatal em certas áreas (direitos humanos fundamentais de primeira dimensão).

Não se discute com a profundidade necessária a transformação das funções judicantes e seus novos papéis em razão da transformação daquele Estado de Direito liberal no Estado Social de Direito, e a evolução deste para a atual conformação de Estado Social e Democrático de Direito.

De fato, com o surgimento, a sedimentação e o desenvolvimento dos direitos humanos fundamentais sociais e de terceira dimensão (transgeracionais), inverteu-se

\footnotetext{
${ }^{212}$ Para um enfoque filosófico sobre a justiça comutativa, confira-se: LOPES, José Reinaldo de Lima. Direitos sociais: teoria e prática. São Paulo: Método, 2006. p. 129-132.
} 
completamente a lógica de atuação estatal: de uma vedação de atuação pelo Estado para uma exigência cada vez maior de sua intervenção, pois o número de direitos assegurados cresce paulatinamente, assim como as pessoas beneficiadas.

Surge, assim, uma nova espécie de conflitos, entre Estado e cidadãos, entre o Estado e a coletividade como um todo, e mesmo entre diversas funções estatais, conflitos esses a serem dirimidos pelo que se passa a chamar de "justiça distributiva"213.

E a quem compete exercer o controle jurisdicional de tais conflitos? Inegavelmente, ao Poder Judiciário ${ }^{214}$, mesmo que com sua arcaica estrutura moldada a partir do modelo de Estado de Direito liberal, datado do século XVIII, e que ainda permanece em termos gerais inalterada, não obstante seja patente sua insuficiência para fazer frente a tais conflitos, típicos do atual modelo de Estado.

\subsection{Rebatendo os principais argumentos contrários à legitimidade do Poder Judiciário em exercer o controle das "políticas públicas"}

\subsubsection{Da alegada violação ao princípio da separação dos poderes}

Não convence o argumento utilizado por aqueles que negam legitimidade ao Poder Judiciário para fazer valer os direitos humanos fundamentais sociais no sentido de que tal intervenção implicaria em violação ao princípio da separação dos poderes ${ }^{215}$.

É sabido que a independência entre as funções estatais deve ser compreendida dentro da lógica dos checks and balances ("freios e contrapesos"), ou seja, como garantia

\footnotetext{
${ }^{213}$ Embora não seja objeto do presente trabalho, indicam-se importantes estudos filosóficos acerca da "justiça distributiva": i) LOPES, José Reinaldo de Lima. Direitos sociais: teoria e prática, cit., p. 132-183; ii) FARIA, José Eduardo (Org.). Direitos humanos, direitos sociais e justiça. 1. ed. 3. tir. São Paulo: Malheiros Ed., 2002, notadamente p. 52-67; iii) FARIA, José Eduardo. Justiça e conflito: os juízes em face dos novos movimentos sociais. 2. ed., rev. e ampl. São Paulo: Ed. Revista dos Tribunais, 1992.

214“'O Judiciário foi alçado a novas funções, com expansão de suas competências, a fim de fazer frente ao próprio agigantamento de Executivo e Legislativo, oriundo de uma transformação das funções do Estado que o tornam cada vez mais burocrático, na finalidade de conseguir de fato exercer o papel de 'contrapeso' não só do Executivo, mas também do Legislativo." ALMEIDA, Luiz Antônio Freitas de. Direitos fundamentais sociais e ponderação: ativismo irrefletido e controle jurídico racional. Porto Alegre: Sérgio Antonio Fabris, 2014. p. 170.

${ }^{215}$ Para aprofundamento sobre o tema, confira-se: i) JORGE NETO, Nagibe de Melo. op. cit., p. 59-71; ii) PASSOS, Daniel Silva. Intervenção judicial nas políticas públicas: o problema da legitimidade. São Paulo: Saraiva, 2014. p. 72-81; iii) CANELA JUNIOR, Osvaldo. Controle judicial de políticas públicas. São Paulo: Saraiva, 2011. p. 65-96; iv) ALMEIDA, Luiz Antônio Freitas de. op. cit., p. 156-174; v) BITENCOURT, Caroline Müller. op. cit., p. 223-245; vi) SCHWARZ, Rodrigo Garcia. Os direitos sociais e a sindicabilidade judicial das políticas públicas sociais no Estado Democrático de Direito. São Paulo: LTr, 2013.
} 
contra o poder absoluto e ilimitado, garantindo-se uma entrega de parcela do poder estatal de forma equilibrada e balanceada a cada função estatal, sendo cada qual dotada de estrutura e regime jurídico próprios, de modo que uma função não se sobressaia às demais, subjugando-as.

A garantia de independência a cada função estatal demanda, de forma imperiosa, a entrega de parcela de poderes fiscalizatórios recíprocos, de modo que cada função possua poder de fiscalização das atividades dos demais, o que garante exatamente a existência de "freios" e "contrapesos" na distribuição das funções estatais.

Jamais tal garantia significou a atribuição de atividades únicas e exclusivas por parte de cada função, de modo a ficar absolutamente afastada a realização de atividades de mesma natureza jurídica pelas outras parcelas do poder estatal, até mesmo porque tal interpretação levaria, inexoravelmente, ao reconhecimento de nichos absolutistas de poder, já que, dentro de seu feixe de atribuições, estar-se-ia falando em uma atuação exclusiva, desprovida de controle por parte das demais funções ${ }^{216}$.

Tal interpretação, ademais, simplesmente desconsidera a necessária harmonia que deve existir entre as diversas funções estatais, como garantia de que tal separação não leve à desconfiguração e à disputa entre tais, mas sim à realização das atividades estatais de forma coordenada, voltada a fins compartilhados, o que exige, inequivocamente, o encontro e debate de fins e objetivos conjuntos a serem perseguidos. É o reconhecimento de que o poder estatal é único, e que a separação de funções serve para controle de excessos, sem desconfigurar a unidade que é o Estado Soberano 217218.

\footnotetext{
${ }^{216}$ Confira-se, a propósito, o item 2 de artigo de minha lavra intitulado "O tempo como elemento viabilizador do cumprimento das sentenças proferidas em sede de controle judicial de políticas públicas", publicado na L \& C - Revista de Administração Pública e Política, v. XVII, 2014, p. 42-48.

217، Aliás, tal regime de cooperação entre os poderes não é novo. Conforme anotado, o próprio regime de separação, tal como idealizado por Montesquieu, previa que o exercício do poder somente seria possível em caso de coincidência de vontades. Assim não ocorrendo, o regime de pesos e contrapesos incumbir-se-á de neutralizar o exercício do poder. Agora, os poderes têm, mais uma vez, que unir forças de modo a desenvolver a normatividade constitucional em toda a sua envergadura e profundidade". PASSOS, Daniel Silva. op. cit., p. 80.

${ }^{218}$ Sobre o papel que o princípio da separação dos poderes passa a exercer no moderno e atual Estado Social Democrático de Direito, confira-se: "A contenção do arbítrio e a limitação do poder, que são os objetivos fundamentais da separação dos poderes, têm, portanto, uma perspectiva diversa e mais rica no Estado pósmoderno. A igualdade é marca dessa mudança. Limitar o poder entre nós implica assegurar que o poder estatal esteja sempre a serviço da igualdade e da promoção do bem comum dos cidadãos por meio de ações positivas. Karl Loewenstein, atento às modificações operadas pelo pós-guerra e pelo Estado do bem-estar social, foi o primeiro autor a propor uma reclassificação das funções estatais com base nas políticas públicas e não na lei. Para ele, as funções do Estado são: policy determination, policy execution e policy control". JORGE NETO, Nagibe de Melo. op. cit., p. 64.
} 
Logo, não há que se falar em violação do núcleo essencial das outras funções estatais em razão do controle jurisdicional e da sindicabilidade dos direitos humanos fundamentais sociais $^{219}$, mas, ao revés, em legitimidade da atuação do Poder Judiciário nesta seara, sob pena de criação de uma esfera de irresponsabilidade estatal nas atividades desempenhadas pelos Poderes Executivo e Legislativo - exatamente o que se buscou coibir no bojo da Revolução Francesa - logo, em reprovável retrocesso histórico.

\subsubsection{Da alegada violação ao princípio da igualdade}

Pelas mesmas razões expostas, não há que se falar em violação ao princípio da igualdade ao se reconhecer o caráter de direitos subjetivos, portanto, acionáveis judicialmente, aos direitos humanos fundamentais sociais.

Como visto, dentro do modelo de Estado Social Democrático de Direito, o Estado é compelido a garantir tais direitos a todos os indivíduos, em um caminho de universalização.

Logo, a lógica do raciocínio não pode levar à restrição da justiciabilidade, mas à sua ampliação, assegurando-se a todos os cidadãos a acionabilidade dos direitos sociais.

Por decorrência, a ofensa à igualdade não está na garantia dos direitos sociais a uma dada classe de pessoas, mas sim no não acesso de outras categorias aos mesmos direitos ${ }^{220}$.

Reforça tal conclusão a existência de direito humano fundamental específico, alçado à condição de garantia constitucional, consistente na inafastabilidade do controle jurisdicional de lesão ou ameaça a direito (artigo $5^{\circ}, \mathrm{XXXV}$, da Constituição ${ }^{221}$ ).

\footnotetext{
${ }^{219}$ Deixo clara, assim, minha posição contrária ao respeitável estudo desenvolvido por Elival da Silva Ramos em sua obra Ativismo judicial: parâmetros dogmáticos. 1. ed. São Paulo: Saraiva, 2010, valendo conferir, a propósito, seu item 12, que trata exatamente da questão do ativismo judicial e da suposta violação à separação dos poderes, p. 111-120.

220“"No entanto, o argumento da igualdade não pode ser mal entendido. Muitas vezes ele surge invocado numa perspectiva política de desvalorização da dimensão jurídica dos direitos sociais. Ou seja, nessa visão política, a subjectivização dos direitos sociais, entendida como atribuição de direitos individuais contra o Estado, redundaria na própria frustração da sua originária essência igualitária, na medida em que a reivindicação e o eventual sucesso da acção judicial individual 'resolveria' apenas o problema particular de um, deixando sem idêntica protecção, em pretensa violação do princípio da igualdade, todos os outros que, apesar de se encontrarem na mesma situação objectiva do peticionante, não puderam, por qualquer razão, recorrer à via judicial. Ora, este argumento só procede parcialmente e numa perspectiva diferente. Por um lado, a possibilidade de accionabilidade judicial por iniciativa e no interesse individual constitui o próprio cerne da existência de direitos. Recusar esta possibilidade a uma pessoa com o argumento de que há outros que não recorreram à via judicial seria a negação da qualidade de direito. Da mesma forma, recusar a procedência material da acção com base neste argumento equivaleria a denegação da justiça". NOVAIS, Jorge Reis. op. cit., p. 120-121.

221 "A lei não excluirá da apreciação do Poder Judiciário lesão ou ameaça a direito".
} 


\subsubsection{Da alegada violação ao princípio democrático}

Também se equivocam, com todo o respeito, aqueles que defendem que a intervenção do Poder Judiciário na seara das políticas públicas implicaria em violação ao princípio democrático.

Constato que tais autores enxergam tal garantia, basilar na atual conformação de Estado Nacional Soberano, ainda em seu formato liberal-burguês do século XVIII, no qual o conceito de democracia quase que se confundia com a noção da regra da maioria. Esta era entendida como o poder que a maioria eleitoral possuía de fazer valer sua vontade sobre a sociedade como um todo, mediante o mecanismo da eleição de seus representantes no parlamento, aos quais competia a elaboração das leis, as quais ainda eram vistas como o centro dos ordenamentos jurídicos estatais.

Há que se recordar que a elaboração doutrinária inicial de Montesquieu foi formulada em um contexto de lutas pelo reconhecimento da classe burguesa como sujeito de direitos, contra o então Estado Absolutista monárquico unipessoal, no qual o poder ficava concentrado, de forma absoluta, nas mãos do monarca.

Logo, por evidente que a elaboração de uma teoria voltada à desconcentração do poder estatal tinha por objetivo maior a criação de um sistema impeditivo da supremacia de uma função perante as demais, com sua consequente limitação.

Agora, ciente de que na prática uma relativa concentração e supremacia de uma das funções estatais sobre as demais era quase que inevitável, Montesquieu procurou concentrar as funções mais nobres junto ao parlamento, pois seus integrantes são eleitos pelo povo, extraindo daí o fundamento de validade e legitimidade para a elaboração das leis, gerais e abstratas, assegurando-se uma igualdade formal, o que na ocasião representou enorme conquista civilizatória.

Assim, no modelo originário de separação de poderes elaborado por Montesquieu, ao Poder Legislativo cabia a função estatal mais nobre e de maior envergadura e responsabilidade - a elaboração das leis formais -, uma vez que seus integrantes eram escolhidos diretamente pelo povo, mediante votação pela regra da maioria, ou seja, mediante a utilização de um critério objetivo e matemático, logo, mais seguro e de mais fácil aceitação pela coletividade. 
Aos outros dois Poderes - Executivo e Judiciário -, historicamente ligados ao monarca, foram atribuídas funções de menor envergadura, já que representavam resquícios do Ancien Régime, derrubado pela Revolução Francesa.

Mas, assim como ocorreu com a noção da separação de poderes, o conceito de democracia foi sofrendo transformações ao longo dos últimos 250 anos, notadamente em razão dos movimentos de: i) ampliação dos direitos humanos fundamentais ${ }^{222}$; ii) reconhecimento de outras classes sociais como sujeitos de direito; iii) reconhecimento do direito de voto às mulheres e, paulatinamente, a todos os cidadãos (sufrágio universal); iv) transformação do modelo de Estado liberal-burguês para o Estado Social, e deste para o atual modelo de Estado Social Democrático de Direito ${ }^{223}$.

Passa-se, pois, da noção inaugural de democracia representativa, na qual o direito de voto era quase que o único direito assegurado, para a noção de democracia participativa, com a criação e garantia de mecanismos de participação semidireta e direta na tomada das decisões estatais estratégicas ${ }^{224}$ (p.e.: referendo, plebiscito, recall, poder de iniciativa, veto popular, audiências públicas, orçamento participativo, dentre outros mecanismos).

Logo, o conceito inaugural simples e restrito de democracia vai se ampliando, na mesma medida em que crescem as demandas populares e se reconhecem direitos às diversas camadas da sociedade, até se chegar ao atual contexto, no qual a preocupação maior está na legitimação das decisões estatais estratégicas tomadas pelas suas três funções clássicas.

Ou seja, a concepção original de que se passava um verdadeiro "cheque em branco" para os representantes eleitos para o parlamento e para o executivo para o desempenho de suas atividades não possui mais validade, uma vez que o atual estágio evolutivo do conceito de democracia exige a criação de uma série de mecanismos de participação popular na tomada das mais diversas decisões estatais.

\footnotetext{
${ }^{222}$ Para a relação intrínseca entre democracia e direitos humanos fundamentais, confira-se: CANOTILHO, José Joaquim Gomes. op. cit., p. 290-291.

${ }^{223}$ Para maior aprofundamento, confira-se: ALBUQUERQUE, Felipe Braga. Direito \& política: pressupostos para a análise de questões políticas pelo judiciário à luz do princípio democrático. Florianópolis: Conceito, 2013. p. 76-82.

${ }^{224}$ Chamo de "estratégicas", para fins desta obra científica, as decisões tomadas por cada uma das funções estatais, ligadas diretamente aos seus fins precípuos: i) programas de governo e políticas públicas, no caso do Poder Executivo; ii) atos de legislar, no caso do Poder Legislativo; iii) atos de decisão, no caso do Poder Judiciário.
} 
Não basta a mera eleição dos representantes. A regra da maioria não é mais suficiente para fazer frente às demandas de participação popular na tomada das decisões estratégicas estatais. Tais decisões não mais se legitimam pelo simples fato de seus atores terem sido democraticamente eleitos.

A própria definição de regra da maioria ${ }^{225}$ sofreu transformações em razão das observações empíricas no sentido de que tal regra, entendida unicamente como a prevalência da posição defendida pela maioria dos eleitores, levou a distorções que culminaram na instituição da "ditadura da maioria", esmagadora dos interesses da minoria e impositiva de um único entendimento sobre cada tema, o que viola, de forma flagrante, o multiculturalismo inerente à condição humana. Havia que se criar mecanismos, assim, para se assegurar os interesses também da minoria, impedindo-se sua fulminação.

Tal compreensão já havia sido argutamente desenvolvida por Hans Kelsen em seu clássico ensaio intitulado "Essência e valor da democracia", escrito em $1929^{226}$.

Também a relevantíssima noção de que a legitimidade das decisões tomadas no parlamento depende da participação efetiva dos diversos grupos eleitos no seio de seu

\footnotetext{
${ }^{225}$ Conceito filosófico moderno e atual para a "regra da maioria" é dado por Campilongo: "Uma definição parcial, incompleta e ciente de suas limitações: a regra da maioria é uma técnica rápida de tomada de decisões coletivas que maximiza a liberdade individual e assegura a ampla e igual participação política dos cidadãos, aproximando governantes e governados por meio de uma prática social de legitimação eventual, finita no espaço e no tempo, que sujeita as decisões à contínua revisão e mantém a sociedade unida." CAMPILONGO, Celso Fernandes. Direito e democracia. São Paulo: Max Limonad, 1997. p. 38. Para maior aprofundamento, indico a leitura das seguintes passagens da mesma obra: p. 27-54 e 107-125. Confira-se, outrossim: CANOTILHO, José Joaquim Gomes. op. cit., p. 329-330.

226“Impedir o domínio de classe é o que o princípio majoritário - no âmbito do parlamentarismo - tem condições de realizar. Já é característico que, na prática, ele se mostre compatível com a proteção da minoria. De fato, a existência da maioria pressupõe, por definição, a existência de uma minoria e, por consequência, o direito da maioria pressupõe o direito à existência de uma minoria. Disto resulta não tanto a necessidade, mas principalmente a possibilidade de proteger a minoria contra a maioria. Esta proteção da minoria é a função essencial dos chamados direitos fundamentais e liberdades fundamentais, ou direitos do homem e do cidadão, garantidos por todas as modernas constituições das democracias parlamentares. (...) A forma típica de qualificação de tais leis constitucionais com respeito às leis ordinárias é representada por um aumento no quorum e por uma maioria especial de dois terços ou três quartos. (...) Essa autolimitação significa que o rol dos direitos fundamentais e das liberdades fundamentais se transforma, de instrumento de proteção do indivíduo contra o Estado, em instrumento de proteção da minoria - de uma minoria qualificada - contra a maioria puramente absoluta; significa que as disposições referentes a certos interesses nacionais, religiosos, econômicos ou espirituais só podem ser decididas depois da aprovação de uma minoria qualificada, portanto só se maioria e minoria estiverem de acordo". KELSEN, Hans. A democracia. Tradução de Ivone Castilho Benedetti, Jefferson Luiz Camargo, Marcelo Brandão Cipolla $e$ Vara Barkow. 2. ed. São Paulo: Martins Fontes, 2000. p. 67-68.
} 
procedimento de tomada, disciplinado juridicamente ${ }^{227}$, aparece no texto elaborado por Kelsen $^{228}$.

Ou seja, já na segunda década do século XX a noção de democracia e de regra da maioria não mais correspondia, em termos teóricos, aos conceitos originários de Montesquieu. Isso de forma contemporânea ao surgimento dos direitos humanos fundamentais sociais, cujas exigências de efetivação iriam pressionar ainda mais no sentido da ampliação dos mecanismos democráticos de participação popular direta e de controle na tomada das decisões estatais estratégicas.

De qualquer sorte, a passagem do modelo de democracia representativa para os de democracia participativa ${ }^{229}$ e deliberativa ${ }^{230}$ também provoca mudanças na forma de concepção do Poder Judiciário.

Em um primeiro momento no sentido de se criticar a suposta ausência de legitimação democrática do Poder Judiciário como função estatal, o que, rapidamente, evolui para o reconhecimento da sua enorme importância em uma função moderadora, de coordenação e mediação dos diversos conflitos sociais, inclusive entre Estado $e$

${ }^{227}$ É por tais razões que Kelsen é grande entusiasta do modelo de democracia parlamentar, a seu ver aquele mais eficaz e coerente em termos de tomada de decisões de acordo com a vontade popular.

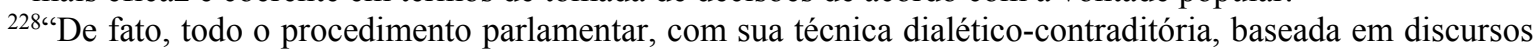
e réplicas, em argumentos e contra-argumentos, tende a chegar a um compromisso. Este é o verdadeiro significado do princípio de maioria na democracia real. Portanto, seria melhor dar a tal princípio o nome de princípio majoritário-minoritário, uma vez que ele organiza o conjunto dos indivíduos em apenas dois grupos essenciais, maioria e minoria, oferecendo a possibilidade de um compromisso na formação da vontade geral, depois de ter preparado esta última integração obrigando ao compromisso acima mencionado, que é a única coisa que pode permitir a formação tanto do grupo da maioria quanto do grupo da minoria: relegar a segundo plano o que separa os elementos a serem unidos, em favor daquilo que une". KELSEN, Hans. A democracia, cit., p. 70.

${ }^{229}$ Para uma abordagem moderna e atual sobre o conceito de democracia, em termos de efetividade no bojo de Estados Nacionais populosos, confira-se a construção do modelo de "poliarquia", no qual vários órgãos e estruturas voltados à tomada de decisões estatais estratégicas são constituídos, com participação popular, modelo esse levado a cabo por Robert Alan Dahl, em sua obra Democracy and its critics. New Haven: Yale University Press, 1989. Para um estudo sobre os diversos modelos de democracia, confira-se: CANOTILHO, José Joaquim Gomes. op. cit., p. 1409-1421.

230“'Imagine, por exemplo, que adotemos a perspectiva da democracia deliberativa. Não obstante seja possível distinguir várias versões diferentes deste modelo, eu proporei aqui uma versão identificada pelas duas características que seguem. Primeiro, suporei que esta visão de democracia demanda decisões públicas a serem tomadas após um amplo processo de discussão coletiva. Segundo, suporei que a visão deliberativa demanda, em princípio, a participação de todos aqueles potencialmente afetados por esta decisão". GARGARELLA, Roberto. Theories of democracy, the judiciary and social rights. In: GARGARELLA, Roberto; DOMINGO, Pilar; ROUX, Theunis (Orgs.). Courts and social transformation in new democracies: an institutional voice for the poor. London: Ashgate Publishing Limited, 2006. p. 26 (tradução do original, em inglês). 
particulares e entre as próprias funções estatais, além de suas primordiais funções de guarda da constituição e de garantidor dos direitos humanos fundamentais ${ }^{231}$.

Atualmente, a maioria da doutrina reconhece o relevantíssimo papel exercido pelo Poder Judiciário em favor da consolidação da democracia, seja em termos de proteção e efetivação dos direitos humanos fundamentais, dentro de um necessário viés contramajoritário $^{232}$, seja em termos de proteção das minorias ${ }^{233}$, uma vez que a legitimidade democrática de tal atuação advém da própria constituição, como ápice do ordenamento jurídico estatal ${ }^{234}$.

E, para que possa fazer frente a essas novas funções e atribuições, o próprio processo judicial passa a sofrer transformações e influxos, voltados à maior abertura $e$ participação de partes e grupos interessados na tomada de decisões.

Assim é que se verifica, nas últimas décadas, a criação de institutos processuais como o amicus curiae e a realização de audiências públicas, para que outras pessoas interessadas sejam ouvidas, que não as estritas partes do processo, tudo com vistas à maior participação da coletividade no processo de tomada de decisões judiciais.

Ou seja, criam-se canais processuais de participação popular na tomada das decisões pelo Poder Judiciário, entendido como novo locus de participação política pela sociedade, a gerar ganhos de legitimidade democrática em seu favor, possibilitando-se sua atividade de intervenção e controle nas políticas públicas.

${ }^{231}$ Confira-se, a propósito: “O fortalecimento democrático exige, em segundo lugar, a atuação de órgãos da justiça constitucional como verdadeiros árbitros da sociedade, agindo como um verdadeiro Poder moderador em defesa da plena aplicabilidade das normas constitucionais e em garantia da integral efetividade na proteção aos Direitos Humanos Fundamentais". MORAES, Alexandre de. Jurisdição constitucional e tribunais constitucionais: garantia suprema da Constituição. 3. ed. São Paulo: Atlas, 2013. p. 62.

${ }^{232}$ Confira-se, a propósito, a interessante natureza de "trunfos contra a maioria" atribuída aos direitos humanos fundamentais por Jorge Reis Novais em sua obra Direitos sociais: teoria jurídica dos direitos sociais enquanto direitos fundamentais, cit., p. 319-331.

${ }^{233}$ Para maior aprofundamento, confira-se: i) ALBUQUERQUE, Felipe Braga. op. cit., p. 127-141; ii) SCHWARZ, Rodrigo Garcia. op. cit., p. 192-200.

234“É, insistimos, da própria Constituição, ou seja, dessa manifestação ímpar, virtuosa e substancialmente democrática do poder soberano do demos, que emana o mandado que pauta a atuação do Judiciário, não como um órgão limitador, mas atualizador e garantidor de uma limitação previamente estabelecida por ela própria (a Constituição) para garantir a sua supremacia (da Constituição) e, portanto, a prevalência de um pacto social concertado em termos políticos, econômicos, sociais e culturais através dela expressado - e, em síntese, a supremacia da vontade soberana do demos consubstanciada no pacto social instituinte. (...) Ademais, a extensão do controle jurisdicional, realidade irrefutável, longe de pautar-se pela falta de legitimação democrática, vem, ao contrário, efetivar o paradigma democrático, superando a chamada dificuldade contramajoritária. Assim, ao menos conjunturalmente, na verdadeira democracia representativa, a tutela dos direitos fundamentais e dos princípios relacionados ao próprio Estado social e democrático de direito não pode estar adstrita, apenas, a órgãos executivos e legislativos, naturalmente sensíveis a demandas que não veiculam possíveis benefícios eleitorais imediatos, ou ainda àquelas demandas que escapam à pauta das prioridades políticas estabelecidas por certa 'lógica de partido"'. SCHWARZ, Rodrigo Garcia. op. cit., p. 194-195. 


\section{Em tal sentido é a proposta formulada por Roberto Gargarella ${ }^{235}$ :}

A pergunta que guiará minha exposição será a seguinte: Dado que queremos que nosso sistema político responda de um modo adequado à vontade das maiorias e que, por sua vez, assegure uma devida proteção às minorias, qual poderia ser o papel do Poder Judiciário (se é que deve assumir algum) dentro deste sistema? Minha resposta estará inserida dentro do que vou chamar de uma "tradição (genuinamente) radical". Isto é, uma tradição que entende que "todos os possíveis afetados" por uma determinada decisão devem tomar parte de tal processo de tomada de decisões; mas que simultaneamente reconhece a falibilidade que é própria dos processos de tomada de decisões majoritárias ${ }^{236}$.

\section{Dentro dessa mesma linha de transformação do Poder Judiciário como novo locus} de debates políticos, com a consequente abertura e criação de canais de participação popular direta, confira-se o conceito de "political accountability" desenvolvido por Siri Gloppen e outros, bem como a função desempenhada pelo Poder Judiciário dentro desta lógica democrática moderna:

A responsabilidade política implica uma relação entre dois conjuntos de atores; cidadãos, que são a principal fonte de legitimação da autoridade política, e os governantes, que são seus agentes. Esta relação envolve a troca de responsabilidades e potenciais sanções como base para o governo legítimo. É uma relação de poder: o governante, a quem os cidadãos têm confiado a autoridade, é obrigado a manter os cidadãos (ou seus representantes) informados e oferecer explicações e justificativas para as decisões tomadas. Se o governante não o fizer, ou a prestação de contas não for satisfatória, os cidadãos (ou seus representantes) podem impor sanções predeterminadas (Goetz and Jenkins, 2005; Schmitter, 2004). (...)

\section{(..)}

\footnotetext{
235“Uma vez aceita essa versão do conceito deliberativo de democracia, e rejeitada a supremacia do judiciário, qual função deveria ser reservada aos juízes, se o caso? Em minha opinião, quando aceitamos que os juízes são subordinados - na verdade, servos - do debate público, aí sim podemos começar a ver o judiciário como um mecanismo crucial do debate público. Com efeito, os juízes estão excepcionalmente bem situados para cumprir essa tarefa, porque sua função principal é receber as reclamações de todos aqueles marginalizados ou severamente afetados pelas decisões dos poderes políticos. Falando em termos institucionais, o judiciário representa o principal canal pelo qual grupos desfavorecidos podem se fazer ouvir, quando os poderes políticos se recusam a tanto ou descartam indevidamente suas reivindicações. Os juízes estão muito bem posicionados para exigir uma justificativa melhor sobre as decisões tomadas por aqueles poderes, em nome do povo e de seus representantes. Desta forma, os juízes podem desempenhar um papel muito importante em relação aos direitos, incluindo os direitos sociais, que são normalmente reivindicados por grupos que se consideram marginalizados pelas forças políticas dominantes. Os juízes podem contribuir decisivamente na "ativação" e no enriquecimento dessas discussões, favorecendo uma tomada de decisões públicas mais imparcial. A necessidade de reforçar a imparcialidade no processo de tomada de decisões deveria ser suficiente para justificar esse tipo de ativismo judicial. Contudo, a intervenção judicial nessas matérias pode ser adicionalmente fundada em razões como as seguintes: a relação entre certos direitos básicos (por exemplo, o direito de cada pessoa de criticar o governo) e a preservação do processo democrático; a conexão íntima que existe entre os direitos sociais e a participação política; e a necessidade de se respeitar a constituição, principalmente quando incluem de forma expressa direitos sociais, como é o caso da maioria dos países latino americanos." GARGARELLA, Roberto. Theories of democracy, the judiciary and social rights, cit., p. 28-29 (tradução do original, em inglês).

${ }^{236}$ Id. Ibid., p. 13 (tradução do original, em espanhol).
} 
Os Tribunais também podem servir como um mecanismo de controle popular ou de prestação de contas para a sociedade, permitindo a indivíduos e grupos usar o contencioso para proteger e promover seus direitos e interesses (Peruzzotti and Smulovitz, 2006). Semelhante ao canal eleitoral, esta é uma relação de responsabilização vertical legalmente especificada. A importância relativa da mobilização jurídica como um canal de responsabilização vertical varia e depende, dentre outras coisas, do quão bem funcionam os outros canais populares de controle. Mas, dada a natureza casuística, geralmente custosa e não representativa do contencioso, possui limitações como principal mecanismo de controle democrático. Isto é, contudo, apenas um aspecto das funções de prestação de contas dos tribunais. Como mencionado, os tribunais são cruciais para o sistema de prestação de contas horizontal entre instituições estatais, na medida em que submetem outros atores estatais à lei e à constituição. Na medida em que eles protegem a lei - como resultado do processo político - eles prestam uma função altamente relevante em termos democráticos. Ao agir de acordo com sua responsabilidade de proteger a lei e a constituição, eles também servem para proteger os canais verticais, de controle popular do governo (o canal eleitoral, a mídia, e o ativismo da sociedade civil) contra tentativas egoístas pelos operadores históricos de evadir-se da prestação de contas ou de bloquear os canais de mudança política ${ }^{237}$.

$\mathrm{Na}$ atual quadra, portanto, longe de carecer de legitimidade democrática, o Poder Judiciário começa a ocupar relevante espaço como locus público de debate acerca das políticas públicas traçadas e implementadas pelos outros poderes constituídos, bem como de cobrança acerca das razões pelas quais os poderes eleitos tomaram certas medidas, em detrimento de outras em prol de classes sociais marginalizadas nos debates políticos clássicos.

De se observar que a legitimidade democrática do Poder Judiciário diz respeito ao controle e fiscalização das políticas públicas implementadas pelo Executivo e Legislativo, bem como de sua inércia inconstitucional, não se defendendo, aqui, a existência de legitimidade para que o Poder Judiciário implemente políticas públicas a partir do "zero", tampouco que tal atividade não possua limites.

\subsection{Grau de alcance da justiciabilidade dos direitos sociais}

Analisados e rechaçados os principais óbices diretos à justiciabilidade dos direitos humanos fundamentais sociais, passo a analisar dois conceitos de extremo relevo no tocante ao grau de alcance de tal controle pelo Poder Judiciário: i) mínimo existencial; ii) reserva do possível.

${ }^{237}$ GLOPPEN, Siri et al. Courts and power in Latin America and Africa. New York: Palgrave Macmillan, 2010. p. 13 e 15-16 (tradução do original, em inglês). 


\subsubsection{Mínimo existencial}

O conceito de mínimo existencial ${ }^{238}$ possui raízes históricas ${ }^{239}$ na Alemanha do pós Segunda Guerra Mundial, uma vez que a Constituição de Bonn, datada de 1949 e ainda vigente, não elenca em seu corpo qualquer direito humano fundamental social, mas unicamente aqueles direitos clássicos de liberdade (primeira dimensão) ${ }^{240}$.

Porém, a ausência de previsão constitucional de direitos humanos fundamentais sociais na constituição alemã não impediu a doutrina e jurisprudência de reconhecer a existência de um dever estatal de providenciar condições e prestações voltadas à proteção dos cidadãos nesta seara.

Ao contrário, desde cedo a doutrina mais abalizada extraiu da cláusula constitucional principiológica do Estado Social os deveres estatais a prestações sociais, ao menos em seu núcleo essencial (=mínimo existencial $)^{241}$.

Ou seja, mesmo sem a previsão expressa na constituição alemã de direitos humanos fundamentais sociais, o enfoque neoconstitucionalista concretista inaugurado por Hesse permitiu a extração, do princípio do Estado Social, de deveres estatais a prestações sociais, garantidores de um mínimo existencial para os cidadãos, em um enfoque voltado à força normativa da constituição e à sua máxima eficácia possível.

\footnotetext{
${ }^{238}$ Conceito referencial de "mínimo existencial" é dado, na doutrina pátria, por Ricardo Lobo Torres, em sua obra basilar sobre o tema: "O mínimo existencial é direito de dupla face: a) aparece como direito subjetivo e também como norma objetiva; b) compreende os direitos fundamentais originários (direitos da liberdade) e os direitos fundamentais sociais, todos em sua expressão essencial, mínima e irredutível; c) do ponto de vista da efetividade apresenta a duplicidade do status negativus e do status positivus libertatis"; TORRES, Ricardo Lobo. op. cit., p. 37-38. Para maior aprofundamento, confira-se p. 35-37.

${ }^{239}$ Para um resumo do surgimento histórico do conceito de "mínimo existencial”, confira-se: LAZARI, Rafael José Nadim de. Reserva do possível e mínimo existencial: a pretensão da eficácia da norma constitucional em face da realidade. Curitiba: Juruá, 2012. p. 91-92.

240“A Lei Fundamental restringe suas garantias jurídico-fundamentais no essencial aos direitos do homem clássicos, ao lado dos quais se colocam algumas garantias e regulações de princípios especiais (por exemplo, artigo $5^{\circ}$, alínea 3, artigo $6^{\circ}, 7$ ). Em comparação com isso, ela renuncia aos 'direitos fundamentais sociais', como eles estão contidos em várias constituições estaduais." HESSE, Konrad. Elementos de direito constitucional da República Federal da Alemanha, cit., p. 170.

241 "Se todas essas obrigações sociais carecem também da concretização e realização pela legislação ordinária, frequentemente também pelo tornar-se ativo administrativo, o princípio do estado social permanece, contudo, um princípio constitucional: ele obriga e legitima o legislador e o poder executivo para o exercício de tarefas estatal-sociais - sem fundamentar, com seu encargo geral, pretensões individuais a um tal exercício ou instruções de ação concretas. Ele garante em seu núcleo aqueles âmbitos jurídicos que pertencem à essência do estado de direito social, como, por exemplo, o direito de proteção dos trabalhadores e direito de horário do trabalho, o direito de ajuda social, direito de provisão ou direito de seguro social, o direito de organização de empresa ou direito do contrato coletivo do trabalho. Um afastamento fundamental das instituições pertencentes à existência básica do estado de direito social está jurídico-constitucionalmente excluído”. Id. Ibid., p. 175-176.
} 
Em razão de tal ausência de arrimo constitucional expresso, Hesse teve que se valer dos direitos humanos fundamentais de liberdade para justificar a existência de efetividade mínima aos direitos sociais, como condição material de garantia daqueles, ditos “originários" 242243.

E a ligação umbilical de tal justificação com o princípio da dignidade da pessoa humana é deixada expressa na seguinte passagem: "A atividade configuradora e concedente dos poderes estatais deve servir, à frente do objetivo, ao asseguramento da existência digna de um ser humano"244 245 . (grifado)

De se observar, pois, que a criação do conceito de "mínimo existencial"246 teve nítido caráter ampliativo da proteção da pessoa humana como sujeito de direitos, instituindo em seu favor um núcleo fundamental de direitos humanos sociais.

Sucede que, no Brasil, o trabalho pioneiro de Ricardo Lobo Torres ${ }^{247}$, claramente influenciado e embasado na realidade da constituição alemã de Bonn de 1949, conclusivo da necessidade de redução do rol dos direitos humanos fundamentais sociais sindicáveis à noção de "mínimo existencial", e que influenciou - e ainda influencia - os trabalhos acadêmicos sobre o assunto em solo pátrio, simplesmente ignorou a existência de abissal discrepância entre a carta constitucional alemã, que silencia sobre tais direitos, e a nossa, atualmente vigente, que traz extenso rol de direitos humanos fundamentais sociais em seu artigo $6^{\circ}$, e os disciplina em termos de regime jurídico por meio de normas dotadas, inclusive, da estrutura de regras jurídicas, nos seus artigos 193 a $232^{248}$.

242“"Ela destina-se à igualdade no sentido de coordenação social justa. Ela serve à liberdade que, depois do tempo, que nos separa do mundo liberal do século XIX, das mudanças radicais sociais e inflações, não mais é só uma questão de proteção diante de intervenções estatais, mas, simultaneamente, também, de uma eficácia estatal ampla, pela qual somente ela pode ganhar realidade”. HESSE, Konrad. Elementos de direito constitucional da República Federal da Alemanha, cit., p. 176.

${ }^{243}$ Também Torres, com arrimo expresso na doutrina alemã, atrela a justificação dos direitos humanos fundamentais sociais à sua condição instrumental de garantia dos direitos clássicos de liberdade: TORRES, Ricardo Lobo. op. cit., p. 40-43.

${ }^{244}$ HESSE, Konrad. Elementos de direito constitucional da República Federal da Alemanha, cit., p. 176.

${ }^{245}$ Para maior aprofundamento sobre a questão da fundamentação do mínimo existencial na dignidade da pessoa humana, confira-se: TORRES, Ricardo Lobo. op. cit., p. 36-37.

${ }^{246}$ Para um apanhado acerca das diversas teses existentes defensoras da redução dos direitos humanos fundamentais sociais ao conceito de mínimo existencial, confira-se: TORRES, Ricardo Lobo. op. cit., p. 53-73. Confira-se, outrossim: i) OLIVEIRA, Fernando Fróes. Direitos sociais, mínimo existencial e democracia deliberativa. Rio de Janeiro: Lumen Juris, 2013. p. 193-252; ii) ALMEIDA, Luiz Antônio Freitas de. op. cit., p. 245-298.

${ }^{247}$ Trata-se do já citado "O Direito ao Mínimo Existencial”.

${ }^{248}$ Indo além, defendo em artigo de minha autoria intitulado "Mínimo Existencial e sua delimitação pela Constituição Federal de 1988: tentativa de objetivação do conceito", publicado junto ao Informativo Jurídico Consulex, v. XXVIII, série 29, 2014, p. 07-14, que a própria Constituição traz, em seu bojo, a fixação de mecanismos objetivos de implementação de alguns direitos sociais, notadamente a garantia de 
Por decorrência, as conclusões nele lançadas trouxeram consequências opostas àquelas buscadas na Alemanha: se, em uma constituição que não traz rol de direitos humanos fundamentais sociais (alemã) a criação do conceito de "mínimo existencial" permitiu extrair tais direitos de princípios basilares como a "dignidade da pessoa humana" e o "Estado Social", com notórios ganhos em termos de eficácia e exigibilidade, em outra constituição, como a brasileira, que traz farto rol de direitos humanos fundamentais sociais, a utilização de tal conceito traz a nefasta consequência da redução de seu sentido e alcance em termos de justiciabilidade, a qual fica limitada a tal núcleo essencial, cuja determinação, aliás, configura tarefa das mais árduas.

É plenamente válida, aqui, a crítica ${ }^{249}$ feita por Jorge Reis Novais ${ }^{250}$ à mera importação dos conceitos doutrinários alemães para modelos constitucionais de viés absolutamente diverso, consagradores expressamente de direitos humanos fundamentais sociais, sem as devidas adaptações e reflexões acerca de sua utilidade e validade.

$\mathrm{Na}$ verdade, em um sistema como o brasileiro, no qual os direitos humanos fundamentais sociais estão assegurados de forma expressa por nossa carta constitucional, inseridos dentro de um regime jurídico protetivo único, dotados de vários mecanismos voltados à máxima efetividade possível, resta despiciendo e inútil o conceito de "mínimo existencial”, que somente se presta a confundir e a desviar o foco das análises doutrinárias, inserindo indevida restrição à efetividade e sindicabilidade de tais direitos $^{251}$.

fonte própria de receitas para a concretização dos direitos sociais à saúde, à previdência social, à assistência social e à educação, o que só reforça o caráter jusfundamental dos direitos sociais em nossa ordem constitucional vigente.

${ }^{249}$ Não obstante Jorge Reis Novais se debruce sobre o sistema constitucional português, e não sobre o brasileiro, já demonstrei no capítulo 3 que a constituição nossa de 1988 foi altamente inspirada na portuguesa de 1976, valendo, para o nosso sistema, as conclusões por ele lançadas em análise ao regime constitucional português.

250“'Perante este quadro, abre-se um fértil campo de sustentação das maiores reservas a uma importação simples e mecânica destes resultados alemães para experiências constitucionais que assentam numa base de partida essencialmente diferente ou até oposta (por exemplo, entre nós, os direitos sociais são expressa e inequivocamente consagrados como direitos fundamentais constitucionais), sem que isso signifique, como dissemos, ignorar todo o legado da riquíssima discussão germânica sobre as questões de fundo". NOVAIS, Jorge Reis. p. 83-84.

${ }^{251}$ Tal, ademais, é o escólio de Jorge Reis Novais: "Mas não se trata unicamente de reconhecer, sem outras consequências, a natureza jusfundamental e constitucional dos direitos sociais. É que, pura e simplesmente, se há direitos constitucionais sociais, isso significa, no mínimo, em Constituição normativa, que os poderes constituídos - todos eles, do legislador aos tribunais - estão constitucionalmente vinculados pelos direitos sociais enquanto direitos fundamentais constitucionais e, logo, ficam radicalmente em causa todas as construções assentes numa pretensa diferença constitucional de natureza e regimes entre direitos de liberdade e direitos sociais, designadamente as construções que, na prática e ao contrário do que fazem com os direitos de liberdade, entregam os direitos sociais ao legislador, ou seja, privam-nos de efectividade jusfundamental. Logo, a base de partida é qualitativamente diferente da alemã, o que tem implicações 
E mais. $\mathrm{Na}$ doutrina pátria, diversos são os trabalhos encontrados a inserir o conceito de "mínimo existencial" como limite à alegação da "reserva do possível", como se existisse um embate entre tais institutos, tratando-os dentro de um viés processualista, de ônus probatório ${ }^{252}$.

Porém, não obstante seu aparente verniz garantista, na verdade tal tratamento doutrinário acaba por amesquinhar o sentido e alcance dos direitos humanos fundamentais sociais, ao reconhecer, como pressuposto, que os mesmos estão, à partida, em uma posição de inferioridade em termos de efetividade e sindicabilidade, se comparados aos clássicos direitos de liberdade. Uma vez mais, simples importação do modelo alemão, sem equivalência com o regime constitucional brasileiro.

Conforme espero ter demonstrado nos capítulos anteriores, o regime jurídico dos direitos humanos fundamentais é único ${ }^{253}$, invariavelmente radicado na constituição, sendo que a divisão em gerações foi pautada unicamente pelo critério da antiguidade histórica em termos de surgimento e sedimentação, possuindo escopo unicamente didático.

Logo, em um regime constitucional como o brasileiro, não há espaço para a utilização do conceito de "mínimo existencial" "254, pois os limites e contornos eficaciais de tais direitos não são fixados a priori, ou seja, não são imanentes, mas decorrem do choque inevitável entre os mesmos e outros direitos assegurados pela constituição ${ }^{255}$.

dogmáticas não negligenciáveis. Assim, entre nós, os direitos sociais, sendo direitos fundamentais constitucionais, gozam, portanto, à partida, do regime dos direitos fundamentais enquanto normas jurídicas vinculativas de força superior e gozam desse regime relativamente a todo o seu conteúdo, tal como os direitos de liberdade, e não apenas relativamente a um dificilmente delimitável 'mínimo social"'. NOVAIS, Jorge Reis. op. cit., p. 84.

${ }^{252}$ Confira-se, a propósito: i) LAZARI, Rafael José Nadim de. op. cit., p. 89-197; ii) KELBERT, Fabiana Okchstein. Reserva do possível e a efetividade dos direitos sociais no direito brasileiro. Porto Alegre: Livr. do Advogado, 2011. p. 98-106; iii) MOREIRA, Alinie da Matta. As restrições em torno da reserva do possível: uma análise crítica. Belo Horizonte: Fórum, 2011. p. 188-192.

${ }^{253}$ Sugiro um rápido retorno, notadamente ao meu capítulo 2 , onde desenvolvi com mais vagar a noção de regime jurídico único protetivo dos direitos humanos fundamentais.

${ }^{254}$ Nesse mesmo sentido, confiram-se os trabalhos de: i) GONÇALVES, Cláudia Maria da Costa. Direitos fundamentais sociais: releitura de uma constituição dirigente. Curitiba: Juruá, 2010. p. 176-189; ii) SIMÕES, Carlos. Teoria \& crítica dos direitos sociais: o Estado Social e o Estado Democrático de Direito. São Paulo: Cortez, 2013. p. 268-277.

${ }^{255}$ Conforme já expus no capítulo 4 , a base teórica disciplinadora dos limites e contornos dos direitos humanos fundamentais utilizada neste trabalho é a diferenciação entre regras e princípios, elaborada por Robert Alexy em sua obra "Teoria dos direitos fundamentais", com os desdobramentos trazidos por Virgílio Afonso da Silva em sua obra "Direitos Fundamentais: conteúdo essencial, restrições e eficácia". É do choque entre os direitos humanos fundamentais garantidos constitucionalmente, mediante normas jurídicas da espécie de princípios, que se verificarão os limites e contornos de cada qual, não de forma apriorística, mas, no caso concreto, mediante atividade jurisdicional de sopesamento ou da utilização da técnica da proporcionalidade, nos termos preconizados pelos dois grandes doutrinadores mencionados. Por isso sigo as conclusões lançadas por Virgílio Afonso da Silva, no sentido de que as normas jurídicas veiculadoras de direitos humanos fundamentais possuem suporte fático amplo, bem como que o seu núcleo 
Neste ponto, concordo integralmente com a argumentação de Cláudia Maria da Costa Gonçalves, que esclarece:

Defende-se, neste estudo, que a Constituição Federal de 1988 estabeleceu direitos fundamentais sociais a partir da concepção das necessidades humanas básicas e não propriamente através do conceito dos mínimos sociais, isto porque trouxe à tona toda uma normatividade tendente não apenas a manter patamares mínimos de prestações sociais, mas sobretudo a universalizar, a médio e longo prazos, as prestações sociais no interior de um determinado grupo que possui seu direito reconhecido constitucionalmente ${ }^{256}$.

Ao fim e ao cabo, continua a prevalecer a máxima da plena justiciabilidade dos direitos lesionados ou ameaçados de lesão, mediante atividade de controle a ser exercida pelo Poder Judiciário, inserida dentre suas funções essenciais, sem exceções em se tratando dos direitos sociais ${ }^{257}$.

\subsubsection{Reserva do possível}

Por fim, passo à análise do consagrado conceito de "reserva do possível”, este sim verdadeiro limite à concretização dos direitos humanos fundamentais, notadamente sociais.

Alerta de enorme relevo deve ser feito desde o início, uma vez que se trata, uma vez mais, de construção alemã, mais precisamente do Tribunal Constitucional Federal alemão, em julgamento proferido na década de 70 , no qual se afirmou a tese da impossibilidade material fática de garantia de acesso universal ao ensino superior ${ }^{258}$.

Logo, as mesmas reservas anteriormente feitas, quando da análise do conceito alemão de "mínimo existencial” e sua importação acrítica para o sistema jurídico pátrio, sem qualquer adaptação ou crivo prévio de viabilidade e utilidade, são aqui renovadas ${ }^{259}$.

essencial é relativo e que as hipóteses de restrição decorrem do choque entre os mesmos no caso concreto (teoria externa). O grande ganho na adoção de tal posição diz respeito à imposição de um ônus argumentativo à autoridade competente para que possa restringir direitos humanos fundamentais. Sugiro um breve retorno ao capítulo 4 para melhor compreensão do tema.

${ }^{256}$ GONÇALVES, Cláudia Maria da Costa. op. cit., p. 186.

257،Uma vez que, em Estado constitucional, com justiça constitucional, cabe ao poder judicial, em princípio, assegurar o cumprimento desses deveres e observância desses direitos, então os direitos sociais constitucionalmente consagrados passam a ser direitos individualmente titulados, oponíveis ao Estado e judicialmente impostos à observância da maioria democrática. Podemos considerar que não foi a escolha política mais acertada, mas, no plano jurídico, esse foi o resultado e a natureza que resultaram da consagração constitucional dos direitos sociais como direitos fundamentais". NOVAIS, Jorge Reis. op. cit., p. 322.

${ }^{258}$ Confira-se, a propósito: i) ALEXY, Robert. Teoria dos direitos fundamentais, cit., p. 435-440; ii) OLIVEIRA, Fernando Fróes. op. cit., p. 41; iii) MOREIRA, Alinie da Matta. op. cit., p. 51; iv) KELBERT, Fabiana Okchstein. op. cit., p. 69-71; v) BITENCOURT, Caroline Müller. op. cit., p. 141-146.

${ }^{259}$ Para maior aprofundamento, confira-se: MOREIRA, Alinie da Matta. op. cit., p. 55-57. 
No tocante ao conceito 260 de "reserva do possível", não obstante respeitáveis posições doutrinárias em sentido diverso ${ }^{261}$, comungo do entendimento daqueles que defendem não se tratar de limite imanente aos direitos humanos fundamentais sociais, mas, de limite externo, decorrente do maior dispêndio embutido em sua concretização ${ }^{262}$, devendo ser entendido sob um tríplice aspecto, a saber: i) da efetiva disponibilidade fática de recursos financeiros para a implementação dos direitos sociais; ii) da disponibilidade jurídica de recursos materiais e humanos (questão orçamentária); iii) da proporcionalidade e razoabilidade da prestação exigível pelo eventual titular do direito ${ }^{263}$.

Ou seja, a reserva do possível representa uma maior dificuldade na concretização dos direitos humanos fundamentais sociais em função de sua carga majoritariamente prestacional, impondo diversos ônus ao Estado em termos de criação e implementação de

${ }^{260}$ Para um apanhado dos conceitos doutrinários acerca da "reserva do possível", confiram-se: i) KELBERT, Fabiana Okchstein. op. cit., p. 71-78; ii) TORRES, Ricardo Lobo. op. cit., p. 103-110.

${ }^{261}$ Interessante viés de análise da questão é aquele atinente ao "custo dos direitos", em que se parte da premissa de que a concretização de todo e qualquer direito implica em elevados custos estatais, sendo que a alguém deve caber a escolha de onde aplicar os recursos públicos (“escolhas trágicas”), viés esse exposto na obra de referência de autoria de Cass Sustein e Stephen Holmes, intitulada "The cost of rights", analisada com profundidade, no Brasil, por Flávio Galdino, em sua obra Introdução à teoria dos custos dos direitos: direitos não nascem em árvores. Rio de Janeiro: Lumen Juris, 2005, para a qual remeto o leitor para que se aprofunde no estudo. Sucede que, dentro das premissas adotadas no presente trabalho, de que os direitos humanos fundamentais sociais são fruto de intensas lutas pelo reconhecimento do ser humano como sujeito de direitos e integram um regime jurídico único, de elevada envergadura constitucional, inseridos no atual enfoque neoconstitucionalista concretista, não há como concordar com as teses desenvolvidas unicamente a partir do enfoque dos direitos sociais sob o prisma dos "custos dos direitos", pois levam, invariavelmente, ao reconhecimento de limites imanentes aos mesmos, com sua colocação em nível inferior de importância e eficácia se comparados com os clássicos direitos de liberdade, logo, fora de um regime jurídico único.

${ }^{262}$ Não obstante concorde com a premissa dos adeptos das teorias relativas aos "custos dos direitos", no sentido de que a concretização de todos os direitos implica em altos custos econômicos, mesmo nos casos dos direitos clássicos de liberdade, nos quais a existência de um aparato estatal mínimo garantidor de tais liberdades públicas (Poderes Executivo, Legislativo e Judiciário, além das estruturas policiais e eleitorais) é condição imprescindível à sua garantia, reputo como inegável que os direitos sociais implicam em deveres prestacionais indeclináveis pelo Estado, o que implica, comparativamente aos direitos de liberdade, em custos mais elevados, a demandar maior arrecadação tributária para se fazer frente aos mesmos. Confirase, a propósito, excelente justificativa apresentada por Virgílio Afonso da Silva, que a meu ver demonstra como a implementação dos direitos sociais é mais custosa do que a dos direitos de liberdade: "A segunda parte da resposta está intimamente ligada a essa primeira: a criação das condições de exercício dos direitos sociais é, pura e simplesmente, mais cara. Isso porque essas condições, além de incluírem tudo aquilo que é necessário para a produção de efeitos das liberdades públicas - proteção, organizações, procedimentos, etc. -, exigem algo a mais. E esse 'algo a mais', além de pressupor recursos financeiros não disponíveis, costuma ser específico para cada um dos direitos sociais - o que aumenta ainda mais seus custos". SILVA, Virgílio Afonso da. op. cit., p. 241.

263“'A partir do exposto, há como sustentar que a assim designada reserva do possível apresenta pelo menos uma dimensão tríplice, que abrange a) a efetiva disponibilidade fática dos recursos para a efetivação dos direitos fundamentais; b) a disponibilidade jurídica dos recursos materiais e humanos, que guarda íntima conexão com a distribuição das receitas e competências tributárias, orçamentárias, legislativas e administrativas, entre outras, e que, além disso, reclama equacionamento, notadamente no caso do Brasil, no contexto do nosso sistema constitucional federativo; c) já na perspectiva (também) do eventual titular de um direito a prestações sociais, a reserva do possível envolve o problema da proporcionalidade da prestação, em especial no tocante à sua exigibilidade e, nesta quadra, também da sua razoabilidade". SARLET, Ingo Wolfgang. A eficácia dos direitos fundamentais, cit., p. 304. 
condições materiais necessárias à sua efetivação, o que implica em maiores gastos estatais se comparados aos custos dos direitos clássicos de liberdade.

A reserva do possível configura instituto presente na concretização de todos os direitos humanos fundamentais - aqui reside a correção do ponto de partida das teorias dos “custos dos direitos”, já que a concretização de todos os direitos impõe custos econômicos - porém, com maior carga sobre os direitos sociais.

Trata-se de conceito englobador de certas limitações econômicas (limites fáticos) e jurídicas (limites jurídicos de natureza tributária e financeiro-orçamentária) específicas, presentes na concretização dos direitos sociais, porém, que de forma alguma implicam em negativa de seu reconhecimento como direitos humanos fundamentais, assegurados constitucionalmente, tampouco representando óbice em termos de sua sindicabilidade.

Tal é o sentido da afirmação feita por Robert Alexy, mesmo em se tratando do sistema constitucional alemão, no qual, conforme já explicitado, sequer há direitos sociais arrolados na respectiva carta constitucional:

\begin{abstract}
Mesmo os direitos fundamentais sociais mínimos têm, especialmente quando são muitos que deles necessitam, enormes efeitos financeiros. Mas isso, isoladamente considerado, não justifica uma conclusão contrária à sua existência. A força do princípio da competência orçamentária do legislador não é ilimitada. Ele não é um princípio absoluto. Direitos individuais podem ter peso maior que razões político-financeiras ${ }^{264}$.
\end{abstract}

A afirmação supra abarca talvez o maior embate atualmente existente entre os doutrinadores acerca do conceito de "reserva do possível": trata-se de uma questão eminentemente fático-econômica ${ }^{265}$, de limites financeiro-orçamentários à concretização dos direitos sociais, ou de uma questão de escolhas $^{266}$ acerca de quais direitos sociais serão implementados, e em qual medida e alcance (escolhas sobre as políticas públicas a serem implementadas)?

\footnotetext{
${ }^{264}$ ALEXY, Robert. Teoria dos direitos fundamentais, cit., p. 512-513.

${ }^{265}$ Tal foi o enfoque dado pelo Tribunal Constitucional Federal alemão quando da análise da questão do acesso universal ao ensino superior, e que contaminou as análises doutrinárias realizadas na Alemanha, em Portugal e, certamente, aqui no Brasil, conforme já verificamos em SARLET (SARLET, Ingo Wolfgang; TIMM, Luciano Benetti (Orgs.). Direitos fundamentais, orçamento e "reserva do possível”. 2. ed. Porto Alegre: Livr. do Advogado, 2010), ALEXY (Teoria dos direitos fundamentais, cit.), SILVA (Direitos fundamentais: conteúdo essencial, restrições e eficácia). Também é a abordagem de: i) KELBERT, Fabiana Okchstein. op. cit., p. 78-89; ii) CANOTILHO, José Joaquim Gomes. op. cit., p. 477-478 e 480-482; iii) LAZARI, Rafael José Nadim de. op. cit., p. 61-62; iv) ALMEIDA, Luiz Antônio Freitas de. op. cit., p. 189-197.

${ }^{266}$ Tal enfoque é típico da doutrina norte-americana, tendo em Cass Sustein e Stephen Holmes sua obra referência, intitulada "The cost of rights", com ressonância no Brasil por parte dos seguintes autores: i) GALDINO; op. cit.; p. 215-235; ii) SCHWARZ, Rodrigo Garcia. op. cit., p. 208-214; ii) BITENCOURT, Caroline Müller. op. cit., p. 152-168.
} 
A resolução do embate passa, necessariamente, pela análise do instituto sob esse duplo enfoque: como limite fático, de índole econômica, e como questão atinente a quem compete fazer as escolhas de onde empregar os recursos finitos.

Ou seja, a questão atinente à concretização dos direitos humanos fundamentais sociais e sua justiciabilidade deve passar, necessariamente, pelo crivo da "reserva do possível", entendida como a existência de limites econômicos e financeiro-orçamentários à sua implementação e, nesse contexto, remeter a quem cabe realizar as escolhas de onde empregar os limitados recursos públicos (as “escolhas trágicas” de Holmes/Sustein).

Tal visão dúplice encontra suporte teórico de peso em Robert Alexy, cujo binômio regra/princípio cai como uma luva em termos de instrumental teórico idôneo, efetivo e útil para se proceder ao deslinde das controvérsias.

Isso porque os direitos sociais, realmente, são veiculados pelas cartas constitucionais mediante normas jurídicas dotadas da natureza de princípios, logo, como "mandamentos de otimização".

Por decorrência, sua atividade de concretização deve se dar dentro das possibilidades fáticas e jurídicas existentes no momento da aplicação do princípio jurídico, para o que os mecanismos do sopesamento e da proporcionalidade representam caminhos seguros e minimamente objetivos de solução de colisões entre os diversos direitos assegurados constitucionalmente ${ }^{267}$.

Dentro de tal visão dúplice, é inegável a correspondência do viés preponderantemente fático-econômico com as (im)possibilidades fáticas na doutrina de Alexy, assim como o viés das escolhas trágicas se insere na doutrina de Alexy como (im)possibilidade jurídica, dizendo respeito às normas de distribuição de competências tributárias, de separação entre os poderes estatais, de elaboração dos orçamentos públicos etc ${ }^{268}$.

Da análise da reserva do possível sob o enfoque da teoria dos princípios de Alexy, com ênfase nos ensinamentos de Virgílio Afonso da Silva, chega-se à conclusão,

\footnotetext{
${ }^{267}$ Sugiro ao leitor um rápido retorno a tais questões, abordadas no capítulo 4, quando tratei da questão atinente à "força normativa dos princípios constitucionais".

${ }^{268}$ Para uma abordagem profunda sobre a reserva do possível dentro da teoria dos princípios de Robert Alexy, confira-se: MOREIRA, Alinie da Matta. op. cit., com ênfase no Capítulo 2; p. 51-101.
} 
inarredável, de que se trata de limite externo ${ }^{269}$ aos direitos humanos fundamentais, notadamente sociais, seja como limite fático, seja como limite jurídico.

De qualquer sorte, conforme já afirmado com lastro em Virgílio Afonso da Silva ${ }^{270}$, a vantagem (e segurança) trazida pela utilização da teoria dos princípios de Alexy em tal seara, tomando por pressupostos um suporte fático amplo e a existência de limites externos aos direitos humanos fundamentais, inclusive sociais, é a atribuição do ônus argumentativo de sua restrição, ou não implementação, ao poder competente para tanto, garantindo-se, assim, plena justiciabilidade aos direitos sociais, o que está de acordo com a noção tão difundida e defendida nesta obra da existência de um regime jurídico único para os direitos humanos fundamentais.

Os ganhos com tal abordagem são relevantes em termos de evolução doutrinária do tema.

Em primeiro lugar, o enfoque sob o prisma eminentemente fático-econômico, como limitação fática à implementação dos direitos sociais, trouxe uma série de novas abordagens e evoluções em torno do conceito jurídico de orçamento, que deixou de ser uma mera peça formal autorizativa de gastos em favor do Poder Executivo, alçando novos objetivos e alcance, como: i) sua evolução em termos de natureza jurídica para lei material, suscetível de controle pelo Poder Judiciário ${ }^{271}$; ii) instrumento de implementação dos direitos humanos fundamentais mediante a adoção de políticas públicas ${ }^{272}$; iii) instrumento de vinculação e controle da atividade executiva, voltado à concretização dos direitos assegurados na constituição federal e nas leis ordinárias ${ }^{273}$; iv) novo locus de decisão

${ }^{269}$ Reside aqui outra das poucas divergências existentes entre a tese ora exposta e aquela defendida por Jorge Reis Novais, uma vez que, para ele, a reserva do (financeiramente) possível aparece como limite imanente aos direitos sociais, não como limite externo. Confira-se, a propósito: NOVAIS, Jorge Reis. op. cit., p. 89-109.

${ }^{270}$ Vide, a respeito, transcrição de passagem da obra de Virgílio Afonso da Silva constante do capítulo 4, bem como nota de rodapé 260 .

${ }^{271}$ Confira-se, a respeito: "Cabe observar que o sistema constitucional orçamentário brasileiro aponta para a natureza material das leis orçamentárias, ao permitir a apresentação de emendas ao projeto de lei orçamentária, bem como ao definir o conteúdo da LDO, em especial, a alteração na legislação tributária, o que coloca em voga o princípio da anualidade fiscal, ao lado da anterioridade tributária, consoante defende, de forma quase isolada, Ives Gandra da Silva Martins". SILVA, Sandoval Alves da. Direitos sociais: leis orçamentárias como instrumento de implementação. Curitiba: Juruá, 2007. p. 165. Para aprofundamento, confiram-se p. 155-197.

272“Do ponto de vista do Estado social, o orçamento não pode ser óbice à concessão dos direitos fundamentais sociais, mas seu instrumento de realização. A ausência de recursos não é indicativo de que o direito fundamental social não poderá ser concedido, mas fator que determinará a redistribuição dos recursos existentes e a promoção das decisões políticas que elegerão os financiadores deste gasto público". CANELA JUNIOR, Osvaldo. op. cit., p. 108. Para aprofundamento, confiram-se p. 101-108.

${ }^{273}$ Confira-se: i) JACOB, Cesar Augusto Alckmin. A "reserva do possível": obrigação de previsão orçamentária e de aplicação da verba. In: GRINOVER, Ada Pellegrini; WATANABE, Kazuo (Orgs.). $O$ controle jurisdicional de políticas públicas. 1. ed. Rio de Janeiro: Forense, 2011. p. 237-281; ii) 
acerca das políticas públicas, mediante a garantia de participação popular ativa por meio do chamado "orçamento participativo" 274 .

Assim é que o orçamento - inauguralmente utilizado como verdadeiro óbice à concretização dos direitos humanos fundamentais sociais e à sua justiciabilidade, uma vez que era entendido como mera peça formal autorizativa da realização de gastos pelo Poder Executivo, único a quem caberia a execução das políticas públicas - atualmente, com o avanço da doutrina e das teorias voltadas à efetivação dos direitos assegurados constitucionalmente, passou a ser considerado como um dos principais instrumentos de concretização dos direitos sociais, a ponto de ser - a meu ver corretamente - entendido como instrumento limitador da discricionariedade do Poder Executivo em matéria de implementação das políticas públicas, previamente aprovadas e acolhidas em tal veículo normativo por parte do Legislativo, e sob o controle jurisdicional pleno, por se tratar de lei material.

Conclusão inarredável é a de que o Executivo passa a estar vinculado às decisões tomadas pelo Parlamento no bojo da lei orçamentária, inclusive com a possibilidade de plena judicialização nos casos em que a lei orçamentária não for cumprida.

Em segundo lugar, o enfoque sob o prisma das "escolhas trágicas" - ou seja, quem é competente para efetuar as escolhas de como os recursos públicos devem ser investidos, dentro da ótica dos limites jurídicos à implementação dos direitos sociais - permitiu o desenvolvimento de várias teorias relacionadas à lógica da institutional choice ${ }^{275}$, por meio da qual se busca fazer uma análise comparativa de quais instituições reúnem as melhores condições para implementar determinadas políticas públicas ${ }^{276}$, tudo com vistas à

MENDONÇA, Eduardo. Da faculdade de gastar ao dever de agir: o esvaziamento contramajoritário de políticas públicas. In: SOUZA NETO, Claudio Pereira de; SARMENTO, Daniel (Orgs.). Direitos sociais: fundamentos, judicialização e direitos sociais em espécie. Rio de Janeiro: Lumen Juris, 2008. p. 231-278.

${ }^{274}$ Confira-se: SIMÕES, Carlos. op. cit., p. 259-266.

${ }^{275}$ Trata-se de corrente teórica com raízes norte-americanas, cuja obra de referência tem como autor Neil K. Komesar, que assim define sua forma de abordagem: "Neste livro, eu me refiro à decisão sobre quem decide como 'escolha institucional'. O termo 'institucional' reflete a realidade de que a decisão sobre quem decide é realmente uma decisão sobre $o$ que se decide. Os tomadores de decisão alternativos não são individuais ou mesmo um pequeno número de indivíduos. Trata-se de processos complexos, como o processo político, o processo de mercado, e o processo judicante, dentro dos quais a interação entre os muitos participantes molda o seu desempenho. Por sua vez, eu me refiro à análise da escolha institucional como sendo uma 'análise institucional comparativa' porque a análise da escolha entre as alternativas de tomada de decisão requer a comparação sofisticada entre essas alternativas." KOMESAR, Neil K. Imperfect alternatives: choosing Institutions in law, economics, and public policy. Chicago: The University of Chicago Press, 1996. p. 03 (tradução do original, em inglês).

${ }^{276}$ Muito importante - e interessante - na análise da institutional choice é o reconhecimento das imperfeições e falhas existentes em todas as instituições passíveis de serem eleitas como competentes para a realização da "escolha trágica", o que é reconhecido de forma expressa por Komesar na seguinte passagem: "A 
utilização dos recursos públicos da forma mais efetiva e eficiente possível (máximo de direitos sociais assegurados com um mínimo de gastos públicos).

Tal forma de análise vem ao encontro da necessária harmonia que deve reinar entre as três funções estatais clássicas, conforme prescrito, inclusive, pelo artigo $2^{\circ}$, da Constituição de 1988, exigindo de cada qual a busca do diálogo e atuação conjunta, de modo que o Estado trabalhe em coordenação e harmonia, sem dispêndio inútil de forças e recursos materiais.

Dentro das premissas adotadas neste trabalho, no sentido da busca da máxima efetividade possível aos direitos humanos fundamentais sociais, é de se ressaltar a importância que a análise sob o prisma da institutional choice traz em termos de ganhos teóricos e criação de mecanismos para melhor equacionamento na distribuição das funções estatais que devem ficar a cargo de cada um dos Poderes: Executivo, Legislativo e Judiciário.

Importante ressaltar que tal análise exige a criação de canais institucionais de atuação conjunta, de modo que as decisões sobre políticas públicas sejam tomadas com a maior participação possível e a maior colheita possível de informações sobre as necessidades sociais, a implicar, sob o prisma do Poder Judiciário, na criação de instrumentos processuais por meio dos quais as demais funções estatais sejam ouvidas exatamente no mesmo sentido de evolução propiciado pelos modelos de democracia plural deliberativa $^{277}$.

escolha institucional é tão difícil quanto essencial. A escolha sempre se dá entre alternativas altamente imperfeitas. As virtudes e fraquezas de uma instituição frente a outra variam de um conjunto de circunstâncias para outro. Por exemplo, se o processo judicante é o melhor protetor dos direitos de propriedade ou o pior garantidor de segurança não é de maneira nenhuma óbvio. Algumas vezes os tribunais serão os melhores protetores da propriedade privada, e algumas vezes esta tarefa será melhor desempenhada pelo processo político. Algumas vezes os tribunais serão os melhores garantidores de segurança, e algumas vezes esta tarefa será melhor desempenhada pelo processo político ou pelo mercado". KOMESAR, Neil K. op. cit., p. 5 (tradução do original, em inglês).

${ }^{277}$ Interessante notar que KOMESAR traz como críticas ao Poder Judiciário exatamente o seu alto custo e a falta de canais de diálogo e de participação dos diversos atores na tomada de decisões, como grandes falhas institucionais a serem corrigidas: "A independência do Judiciário, que caracteriza o começo e o final de várias das análises institucionais dos tribunais, possui um alto preço. Em busca de independência e imparcialidade e para restringir os piores males de um judiciário subjugado pelo povo, regras, procedimentos e práticas aumentam tanto os custos de participação no processo judicante que muitas questões importantes, embora maltratadas em outro lugar, não serão julgadas. As mesmas regras e procedimentos diminuem a perícia dos tomadores de decisão judicial se comparados aos funcionários no processo político e restringem o acesso dos tribunais a importantes informações. O processo judicante formal e hierárquico tem dificuldades em se expandir e as tensões resultantes produzem dispositivos de racionamento com implicações problemáticas em termos de comparação institucional.” Id. Ibid., p. 149-150 (tradução do original, em inglês). 
Ganhar-se-á, e muito, em termos de legitimidade e aceitação popular no caso da adoção de tais ideais como norteadores dos processos de tomada das "decisões trágicas" pelos agentes estatais.

Ademais, cria-se uma alternativa teórica inteligente à velha visão doutrinária que se limita a criticar as deficiências e imperfeições do Poder Judiciário, sem levar em conta uma análise comparativa entre instituições ${ }^{278}$.

Em resumo: a abordagem institucional comparada joga luzes sobre a necessidade de se garantir ampla participação na tomada de decisões sobre políticas públicas, bem como de atuação conjunta e harmônica das funções estatais, além de evidenciar a necessidade da remodelação do Poder Judiciário para que possa fazer frente às demandas coletivas.

Não representa óbice, mas, ao contrário, reforça a importância do Poder Judiciário no controle da tomada de decisões pelo Executivo e Legislativo, no sentido de se assegurar a concretização dos direitos humanos fundamentais sociais.

\subsection{Considerações finais}

Procurei fazer, neste capítulo, uma análise crítica dos principais óbices, levantados pela doutrina mais abalizada, à justiciabilidade dos direitos humanos fundamentais sociais.

Evidente que, dentro das premissas por mim adotadas nos quatro primeiros capítulos, o objetivo de tal análise foi a demonstração de como tais óbices, ao invés de inviabilizar a atividade de controle da implementação dos direitos humanos fundamentais sociais pelo Poder Judiciário, na verdade representaram suporte teórico idôneo e relevante para demonstrar a premente necessidade de uma reforma estrutural do Poder Judiciário, para que possa cuidar da justiciabilidade de tais direitos.

\footnotetext{
${ }^{278}$ Crítica acertada a tal visão, antiga e ultrapassada, é apresentada da seguinte forma: "Por essa razão, ao lado do debate a respeito dos fins da ação estatal, deve o juiz ou o formulador de política pública levar em consideração também a análise institucional. Essa formulação não deixa de ser o objeto central dos trabalhos recolhidos sob a designação 'crítica da capacidade institucional', para os quais determinadas características institucionais do Judiciário limitam sua capacidade de lidar com questões coletivas. Entretanto, os trabalhos dessa abordagem centram o foco apenas e tão somente nas falhas institucionais do processo adjudicatório, sem compará-las com as falhas e limitações das demais instituições, em especial o processo político (Executivo e Legislativo) e o processo de trocas (mercado). Contra essa abordagem monoinstitucional é que se voltou a segunda crítica: sendo todas instituições imperfeitas, é imprescindível uma análise institucional comparada, que pondere as forças e fraquezas relativas de cada um". BADIN, Arthur. Controle judicial das políticas públicas: contribuição ao estudo do tema da judicialização da política pela abordagem da análise institucional comparada de Neil K. Komesar. São Paulo: Malheiros Ed., 2013. p. 158.
} 
A própria evolução histórica e teórica dos institutos ora tratados - notadamente os conceitos de separação dos poderes e de democracia - evidencia a viragem conceitual ocorrida ao longo das últimas décadas: de um viés crítico ao Poder Judiciário como poder legitimado à sindicabilidade dos direitos sociais, dentro do enfoque das "políticas públicas", para o reconhecimento da sua importância como locus legítimo à efetivação do controle sobre as atividades desempenhadas pelo Executivo e Legislativo.

Tais transformações passaram a gerar reflexos diretos sobre os outros dois institutos intimamente relacionados ao controle da concretização dos direitos sociais pelo Poder Judiciário - mínimo existencial e reserva do possível -, a ponto de se evoluir, em termos teóricos, de uma fase inicial de defesa quase que absoluta de tais óbices para uma fase, atual, de grande crítica, e até mesmo da convicção sobre a inutilidade dos tais óbices (caso do conceito de mínimo existencial).

Ao fim e ao cabo, espero ter demonstrado como, na atual quadra, a preocupação e evolução teóricas em torno da efetividade dos direitos humanos fundamentais sociais levou ao reconhecimento, por parte de importante e extensa parcela dos doutrinadores, da legitimidade e plena sindicabilidade de tais direitos pelo Poder Judiciário, deslocando os debates para o plano das necessárias reformas a serem empreendidas para que tal função estatal consiga exercer, de forma legítima e eficiente, tal controle, inclusive, dotando-o dos necessários instrumentos materiais de concretização dos direitos sociais ${ }^{279} 280$.

\footnotetext{
${ }^{279}$ Neste mesmo sentido, da plena efetividade das normas constitucionais veiculadoras dos direitos sociais, confira-se importante escólio de Canotilho: "Do que se escreveu a propósito dos direitos sociais como direitos subjectivos constitucionais, poderemos e deveremos ver em que é que reside a força jurídicoconstitucional dos direitos económicos, sociais e culturais. O Ac. $n^{\circ}$ 39/84 do Tribunal Constitucional relativo à extinção legal do Serviço Nacional de Saúde fixou alguns traços juridicamente constitutivos das normas constitucionais consagradoras de direitos económicos, sociais e culturais: (i) os direitos fundamentais sociais consagrados em normas da Constituição dispõem de vinculatividade normativoconstitucional (não são meros 'programas' ou 'linhas de direção política'); (ii) as normas garantidoras de direitos sociais devem servir de parâmetro de controlo judicial quando esteja em causa a apreciação da constitucionalidade de medidas legais ou regulamentares restritivas destes direitos; (iii) as normas de legislar acopladas à consagração de direitos sociais são autênticas imposições legiferantes, cujo não cumprimento poderá justificar, como já se referiu, a inconstitucionalidade por omissão; (iv) as tarefas constitucionalmente impostas ao Estado para a concretização destes direitos devem traduzir-se na edição de medidas concretas e determinadas, e não em promessas vagas e abstractas; (v) a produção de medidas concretizadoras dos direitos sociais não é deixada à livre disponibilidade do legislador, embora este beneficie de uma ampla liberdade de conformação quer quanto às soluções normativas concretas quer quanto ao modo organizatório e ritmo de concretização". CANOTILHO, José Joaquim Gomes. op. cit., p. 482.

${ }^{280}$ Em termos de prática jurisdicional, excelentes são as observações e exemplos, carreados por Schwarz, de atuação eficiente do Poder Judiciário, dentro de seu espectro constitucional de funções: "Por outro lado, muitas vezes as decisões em questão não são unilaterais, dos tribunais, mas têm sido entabuladas a partir de um diálogo não necessariamente condescendente com os demais poderes públicos, instando-os à reparação de ações e omissões inconstitucionais, relacionadas aos direitos sociais. Assim, os tribunais têm emitido, em alguns países, como no Brasil e em Portugal, declarações pelas quais afirmam que uma política tem
} 
De qualquer sorte, os limites e contornos, externos, delineados à justiciabilidade dos direitos humanos fundamentais sociais, notadamente pela cláusula da "reserva do possível", não afetam a atividade de controle em si, mas, dirigem-se, em termos processuais, notadamente à fase de execução do julgado, razão pela qual concordo com as observações de Canela Júnior:

Durante a fase declaratória do direito, portanto, não é dado ao órgão jurisdicional
absorver a questão econômico-financeira para paralisar sua atividade. Isto
representaria, em comparação com o plano privado, a esdrúxula figura na qual o
devedor não seria condenado à reparação do dano, porque não dispõe de
patrimônio suficiente para o adimplemento futuro do título executivo judicial ${ }^{281}$.

A partir do próximo capítulo, passarei a abordar própria e diretamente o objeto principal deste estudo: o regime jurídico constitucional brasileiro garantidor do direito humano fundamental à previdência social, inserido dentro da seguridade social.

Para tanto, utilizarei os mecanismos e teorias abordados nestes capítulos introdutórios, de suma importância em termos de instrumental necessário a uma visão efetiva dos direitos relacionados à previdência social, com enfoque predominante sobre as prestações estatais relacionadas à contingência da incapacidade laboral, ou seja, os benefícios por incapacidade.

Ao final desta caminhada, espero demonstrar como o enfoque calcado no binômio teórico Teoria Crítica (na vertente da Escola de Frankfurt)/neoconstitucionalismo possibilita uma releitura do direito humano fundamental à previdência social, com grandes e reais ganhos em termos de concretização e de garantia efetiva.

É o que passo a fazer.

elementos inconstitucionais, mas, para evitar consequências econômicas ou sociais indesejadas, deixam de anulá-la de imediato, determinando ao legislador ou à administração pública, em um tempo razoável, a sua adequação ao ditado constitucional. Por vezes, a tradicional atuação dos tribunais frente a graves vulnerações de direitos tem dado lugar a sentenças não meramente declaratórias da inconstitucionalidade, mas a verdadeiras structural injunctions, decisões que determinam as medidas concretas a serem adotadas pelos poderes públicos, fixam um cronograma de implantação e determinam outras medidas que assegurem a efetividade das próprias decisões. Nesses casos, a gravidade e a complexidade da situação justifica, inclusive, um amplo diálogo entre os tribunais, os poderes públicos e os próprios sujeitos afetados, que se prolonga também à fase de execução da sentença”. SCHWARZ, Rodrigo Garcia. op. cit., p. 211-212.

${ }^{281}$ CANELA JUNIOR, Osvaldo. op. cit., p. 103. 


\section{DA PREVIDÊNCIA SOCIAL COMO DIREITO HUMANO FUNDAMENTAL DE SEGUNDA DIMENSÃO (=direito social) VOLTADO À PROTEÇÃO DAS CHAMADAS CONTINGÊNCIAS SOCIAIS}

\subsection{Introdução}

Passo, a partir do presente capítulo, a analisar especificamente o direito humano fundamental à previdência social, dentro do qual se encontram as prestações sociais objeto propriamente dito deste trabalho: os benefícios por incapacidade.

Sua inserção como espécie de direito humano fundamental social é inegável na atual etapa de desenvolvimento teórico da matéria, conforme já tive oportunidade de demonstrar ao longo do capítulo 2, ao qual remeto o leitor.

De qualquer sorte, é importante retomar sua previsão e proteção expressas no plano internacional, inserido que se encontra nos artigos 22 e 25, da Declaração Universal dos Direitos Humanos (Resolução n. 217-A, de 10 de dezembro de 1948, da Organização das Nações Unidas), além do artigo $9^{\circ}$, do Pacto Internacional dos Direitos Econômicos, Sociais e Culturais (Resolução n. 2.200-A, da ONU, datada de 16 de dezembro de $1966)^{282}$.

Já no plano interno, sua elevação à categoria de direito humano fundamental social previsto na Constituição é inegável, previsto que se encontra expressamente no artigo $6^{\circ}$, com os vários desdobramentos e regras garantidoras de sua eficácia e implementação fática (artigos 194, 195, 201 e 202 da Constituição).

Como direito humano fundamental social, seu surgimento e sua positivação ocorrem durante a evolução histórica do Estado Liberal para o Estado Social, entre os séculos XVIII e XIX, como resultado do processo de lutas pelo reconhecimento dos trabalhadores como sujeitos de direitos ${ }^{283}$, bem como dentro da lógica de sacralização da pessoa humana (vide capítulo 1).

\footnotetext{
${ }^{282}$ Para um panorama geral sobre os processos de constitucionalização e internacionalização do direito humano fundamental à previdência social, confira-se: VIDA SORIA, José et al. Manual de seguridad social. 7. ed. Madrid: Tecnos, 2011. p. 33-36.

283،Nos primórdios da relação de emprego moderna, o trabalho retribuído por salário, sem regulamentação alguma, era motivo de submissão de trabalhadores a condições análogas às dos escravos, não existindo, até
} 
Ademais, o direito à previdência social possui relação intrínseca com o próprio direito ao trabalho ${ }^{284}$, já que possui o escopo primordial de assegurar proteção social estatal aos trabalhadores impossibilitados para o labor, garantindo-lhes uma prestação substitutiva de sua remuneração.

Logo, a definição de um conceito de previdência social passa, necessariamente, pela elaboração de um sistema estatal social protetivo do trabalhador, voltado à sua assistência material quando da ocorrência de eventos geradores de sua impossibilidade para o trabalho 285 .

\subsection{Evolução histórica}

Em termos de evolução histórica, é certo que, desde os primórdios, o ser humano já se preocupava com os infortúnios futuros que pudessem inviabilizar sua sobrevivência, razão pela qual a busca de formas de assistência aos desamparados é algo tão antigo quanto a própria existência humana.

Sucede que, inicialmente, tal proteção cabia a cada qual, sendo exclusivamente privada, o que impulsionou até mesmo o surgimento de diversas formas de organização humana, desde os laços mais próximos de parentesco, até regimes mais abrangentes, como as corporações de ofício.

então, nada que se pudesse comparar à proteção do indivíduo, seja em caráter de relação empregadoempregador, seja na questão relativa aos riscos da atividade laborativa, no tocante à eventual perda ou redução da capacidade de trabalho. Vale dizer, os direitos dos trabalhadores eram aqueles assegurados pelos seus contratos, sem que houvesse qualquer intervenção estatal no sentido de estabelecer garantias mínimas. Começaram, então, a eclodir manifestações dos trabalhadores por melhores condições de trabalho e de subsistência, com greves e revoltas - violentamente reprimidas pelo próprio Poder constituído. Surgiram daí as primeiras preocupações com a proteção previdenciária do trabalhador, ante a inquietação dos detentores do poder nos Estados com a insatisfação popular, o que acarretou a intervenção estatal no que diz respeito às relações de trabalho e segurança do indivíduo quanto a infortúnios". CASTRO, Carlos Alberto Pereira de; LAZZARI, João Batista. Manual de direito previdenciário. 16. ed. Rio de Janeiro: Forense, 2014. p. 4.

284، O Direito Previdenciário nasce com o Direito do Trabalho, tendo por objetivo minorar as diferenças de classes, de modo a assegurar uma vida digna ao trabalhador. Teve, também, por intuito, diminuir as diferenças sociais entre os trabalhadores e distribuir renda". MARTINS, Sérgio Pinto. Direito da seguridade social. 34. ed. São Paulo: Atlas, 2014. p. 301.

285“'O Direito Previdenciário é fruto da revolução industrial e do desenvolvimento da sociedade humana, principalmente em decorrência dos inúmeros acidentes de trabalho que dizimavam os trabalhadores. Este ramo do direito visa à cobertura dos 'riscos sociais, tomada a expressão no seu sentido comum de acontecimento incertus na $\boldsymbol{e}$ incertus quando que acarrete uma situação de impossibilidade de sustento próprio e da família'. Santoro Passarelli afirma que a previdência social não pretende uma função indenizatória, mas uma função de alívio da necessidade social, fornecendo ao trabalhador não as prestações equivalentes àquelas que ele tinha antes do evento, mas somente as correspondentes a um mínimo vital. A necessidade vem avaliada objetivamente com respeito, dentro de certos limites, às retribuições e, portanto, ao teor da vida do trabalhador como necessidade socialmente relevante". HORVATH JÚNIOR, Miguel. Direito previdenciário. 9. ed. São Paulo: Quartier Latin, 2012. p. 21. 
Nos primórdios, os regimes protetivos tinham natureza jurídica assistencialista, ou seja, buscavam ajudar pessoas necessitadas, notadamente os indigentes. Isso sem a participação estatal.

Também se verificou a constituição de fundos de natureza mútua, ou seja, grupos de pessoas que, por vínculo contratual, se cotizavam de modo a obter proteção financeira no caso da ocorrência de infortúnios. São exemplos: contratos de seguro marítimo, sendo o mais antigo datado de 1344, as confrarias, as corporações de ofício, dentre outras organizações $^{286}$.

Com o surgimento dos Estados modernos, o caráter assistencial ainda predominou, sendo o primeiro marco normativo de criação de um sistema protetivo dos indigentes o Poor Relief Act, britânico, de 1601.

Sob o influxo do liberalismo burguês, com ênfase na garantia das liberdades públicas, cujos ideais moldaram o modelo de Estado Liberal, não fazia sentido a criação de uma estrutura estatal voltada à proteção dos trabalhadores em caso de impossibilidade de se sustentarem financeiramente. A lógica reinante era a da autotutela, de modo que cabia a cada ser humano se preparar para fazer frente a eventual ocorrência de infortúnios.

Somente com a passagem para o modelo de Estado Social, com a positivação e garantia de direitos humanos fundamentais sociais - voltados à criação de estruturas e mecanismos efetivadores da igualdade material entre os cidadãos, logo, redutores das enormes desigualdades econômicas verificadas nas décadas seguintes à Revolução Industrial -, é que as preocupações se voltaram à criação de uma estrutura estatal garantidora de proteção social aos trabalhadores em caso de ocorrência de eventos inviabilizadores de sua manutenção financeira pelo trabalho ${ }^{287}$.

\footnotetext{
286“Caracuel e Ortega, com apoio em Almansa Pastor, mencionam que antes da Revolução Industrial, utilizavam-se, para a prevenção ou a solução dos riscos sociais, das chamadas 'técnicas inespecíficas'. Estas consistiam, basicamente: a) na poupança (renúncia a um consumo atual com vistas a um eventual gasto futuro); b) na beneficência (consistente na ação de um benfeitor, seja uma pessoa altruísta, ou, o que é mais usual, na obra de uma instituição de caridade, comum ou religiosa); c) na mutualidade ('técnica que se baseia na solidariedade de um grupo social homogêneo que, afetado pelo mesmo tipo de riscos, decide pôr em comum uma parte de suas poupanças para fazer frente a situação de necessidade diante destes riscos, que qualquer um dos membros possa vir a sofrer'); d) no seguro privado (trata-se de técnica substancialmente mais apurada, nascida no auge do Mercantilismo, no século XV, quando os mercadores das cidades do Norte da Itália sentem a necessidade de proteção contra eventuais perdas de mercadorias, em especial, naufrágios e roubos. Pagava-se uma quantidade de dinheiro a um banqueiro - posteriormente, a companhias seguradoras - que responderiam em caso de sinistro)". BELTRAN, Ari Possidonio. Direito do trabalho e direitos fundamentais. São Paulo: LTr, 2002. p. 55.

${ }^{287}$ Tal realidade restou muito bem constatada e descrita, da seguinte forma: "É mesmo como consequência da Revolução Industrial que, no Século XIX, se verifica grave repercussão de contingências que impediam
} 
É assim que surge, historicamente, na então Prússia (atual Alemanha) de Otto von Bismarck, o modelo de seguro social, precursor do modelo de previdência social, e que atualmente desembocou no intrincado e abrangente modelo de seguridade social ${ }^{288}$.

O modelo de seguro social ${ }^{289}$ foi, inegavelmente, o primeiro adotado pelos Estados soberanos na busca da institucionalização de um sistema de proteção social ao trabalhador em face da ocorrência de infortúnios.

Foi inaugurado pela Prússia, mediante a edição das leis de 16 de junho de 1883, 6 de julho de 1884 e 22 de junho de 1889, as quais criaram, respectivamente, o segurodoença, o seguro contra acidentes de trabalho e o seguro contra invalidez e velhice.

Tratava-se de uma verdadeira espécie de seguro ${ }^{290}$, adaptada do regime geral civilista, mediante a instauração de um regime contributivo obrigatório voltado à garantia

uma pessoa de obter recursos pelo exercício de sua atividade profissional. Essas situações de risco de subsistência e os estados de necessidade decorrentes passaram a ocupar o centro da agenda política de vários países. Começava a ser necessária a intervenção estatal para a conciliação de interesses e necessidade dos capitalistas e da classe trabalhadora. São os trabalhadores assalariados industriais que aparecem como principal contingente de pessoas a ser protegido pelas modernas políticas sociais, na medida em que se dissolviam as redes tradicionais de solidariedade. A história da proteção social registra primeiramente, contudo, a adoção de técnicas inespecíficas de proteção, assim consideradas porque correspondiam às 'técnicas do direito comum', especialmente a poupança individual, o seguro privado e a previdência coletiva, que guardavam a nota da facultatividade. (...) Mas a cobertura dos riscos sociais não poderia ser deixada à 'ação errática e desigualitária da beneficência' e tampouco submeter a pessoa que pretende o auxílio a provas deprimentes de sua necessidade, considerando-se necessitado apenas aquele que logra demonstrar a carência mediante seus lamentáveis signos de miséria”. ROCHA, Daniel Machado da; SAVARIS, José Antonio. Curso de direito previdenciário. Curitiba: Alteridade, 2014. v. 1, p. 41-42.

${ }^{288}$ Resumo esclarecedor das diversas etapas históricas de evolução dos modelos de proteção ao trabalhador em face de infortúnios impossibilitadores de seu sustento financeiro é o seguinte: "É possível, de acordo com o que já foi exposto, afirmar que a evolução da proteção social no mundo compreende quatro estágios, sendo cada um deles caracterizado por uma técnica específica de tutela social, a saber:

- assistencialismo: caracteriza-se pela ação caritativa de membros da comunidade em favor daqueles desassistidos socialmente. É uma ação espontânea, desinteressada e desorganizada de membros e instituições da coletividade, sem qualquer participação estatal;

- mutualismo: é a técnica de proteção 'por meio da qual um grupo de pessoas promete ajudar-se mutuamente em qualquer eventualidade futura. Forma-se, desta maneira, um fundo comum destinado a este fim'. Tem natureza contratual e não conta com a interveniência estatal;

- previdência social: seguro social obrigatório, de caráter legal, voltado para o trabalhador e seus dependentes econômicos;

- seguridade social: sistema amplo de proteção social, que ampara todas as necessidades sociais, independentemente de contribuição". DIAS, Eduardo Rocha; MACÊDO, José Leandro Monteiro de. Curso de direito previdenciário. 3. ed. São Paulo: Método, 2012. p. 72-73.

${ }^{289}$ Excelente apanhado acerca do surgimento do modelo prussiano de seguro social é dado por ROCHA, Daniel Machado da; SAVARIS, José Antonio. op. cit., v. 1, p. 43-47. Confira-se, também: CONCEIÇÃO, Apelles J. B. Segurança social: manual prático. 8. ed. Coimbra: Almedina, 2008. p. 37-46.

290“A A previdência social, na acepção bismarkiana, tem uma evidente correlação com a técnica do seguro, pois cabe ao interessado, em regra, efetuar o pagamento do prêmio à seguradora visando eventual indenização. Evidentemente, o seguro social apresenta algumas especificidades, como a cotização forçada e a existência de riscos previsíveis (e.g., idade avançada) dentre as necessidades sociais cobertas". IBRAHIM, Fábio Zambitte. Curso de direito previdenciário. 16. ed. Niterói: Ímpetus, 2011. p. 53-54. 
do pagamento de uma renda aos trabalhadores quando da ocorrência de certos eventos infortunísticos, impossibilitadores da continuidade do trabalho assalariado.

Não era um regime universal, mas dividido por categorias de trabalhadores, e voltado principalmente àqueles de baixa renda, com o escopo de garantir uma renda vital mínima em caso de incapacidade para o trabalho.

Ademais, tratava-se de um modelo de capitalização, ou seja, do qual somente participavam os trabalhadores diretamente interessados, e beneficiados pelas prestações securitárias fixadas, no caso da ocorrência de eventos previamente fixados em lei.

Longe de representar uma guinada rumo à adoção de um modelo socialista, tais medidas visavam exatamente o contrário, ou seja, o combate da expansão socialista pela burguesia capitalista, mediante a criação de mecanismos de proteção social mínima aos trabalhadores, de modo a apaziguar e acalmar o clima de elevada insatisfação e de confronto que havia atingido os países europeus que sofreram as transformações econômicas decorrentes da Revolução Industrial ${ }^{291}$.

Tal modelo, compartimentado e de abrangência limitada, acabou se expandindo para um modelo universalizante, de proteção global e repartição simples, fincado na solidariedade, com a participação e contribuição de toda a coletividade para sua manutenção e sustento, fruto das grandes crises capitalistas enfrentadas no período pós Primeira Guerra Mundial, com forte influência norte-americana e britânica.

Surge, assim, o atual modelo de seguridade social, de grande abrangência em termos de participantes e beneficiários, bem como de infortúnios cobertos mediante prestações estatais, marcadamente influenciado pelas ideias econômicas desenvolvidas por

\footnotetext{
${ }^{291} \mathrm{Tal}$ realidade restou muito bem demonstrada, da seguinte forma: "Com efeito, o governo do chanceler alemão VON BISMARCK anuncia no Parlamento quase que de surpresa, em 1883, a criação de alguns 'Seguros Sociais'. Seu sentido político está e estará marcado pela frase de seu correspondente discurso onde o chanceler disse: 'Com estas medidas [...] vamos cortar a erva debaixo dos pés dos senhores socialdemocratas'. Nesta trilha política, entre 1883 e 1889, se instauram, na Alemanha, os principais eixos da proteção social 'prestacional': os seguros de saúde, de acidentes de trabalho e de invalidez e de velhice. Trata-se da aparição da primeira grande medida política - o primeiro grande marco - e normativa de institucionalização do 'Seguro Social', que sobrevive até hoje, não obstante sua importância institucional tenha experimentado relevantes - decisivas - alterações. O sentido nada filantrópico da medida, seu sentido de 'contenção' da desestabilização social, é flagrante. O Seguro Social está dirigido aos obreiros industriais, inclusive, em princípio, somente aqueles de qualificação mais baixa; baseia-se em uma cotização parcialmente empresarial, em uma gestão pública ou parcialmente pública, não lucrativa, que dá lugar a Caixas independentes e, sobretudo, a inscrição ao Seguro Social é obrigatória. Exatamente como se deu com a 'Legislação Social Obreira', no âmbito do trabalho por conta dos outros, a 'Legislação dos Seguros Sociais' se evidencia como uma colossal medida defensiva e de reação conservadora frente ao perigo subversivo da 'Questão Social'”. VIDA SORIA, José et al. op. cit., p. 30 (tradução do original, em espanhol).
} 
John Maynard Keynes ${ }^{292}$, defensor do intervencionismo estatal como mola propulsora do crescimento econômico em períodos de crise capitalista.

Tais ideais permitiram o surgimento do New Deal, como conjunto de medidas adotadas pelos Estados Unidos da América como forma de superar a devastadora crise financeira de 1929, bem como do Plano Marshall, também elaborado pelos Estados Unidos, voltado à reconstrução mundial da economia, esmagada pela Segunda Guerra Mundial.

Em ambos o intervencionismo estatal serviu de mola propulsora à retomada do crescimento econômico, tendo na criação de um regime universalizante e unitário de seguro social um de seus pilares.

Assim é que restou editado nos Estados Unidos, em 1935, o Social Security Act, como marco histórico de surgimento do modelo de seguridade social ${ }^{293}$ : amplo, abrangente, universalizante, voltado à proteção sistemática e institucional da miséria e dos infortúnios inviabilizadores do trabalho por parte dos trabalhadores ${ }^{294}$.

Porém, foi o chamado "Plano Beveridge"295, elaborado na Inglaterra por Lord Willian Henry Beveridge, em 1941, que representou o verdadeiro divisor de águas na

\footnotetext{
292، Antes da Segunda Guerra Mundial, aparece na Inglaterra a figura de KEYNES, e de suas obras de teoria econômica, que trazem ao pensamento político-econômico e à ação política uma nova forma de gerir as crises da economia liberal, chamada quase que ritualmente como 'keynesianismo'. Tratava-se de ativar a economia, convertendo o setor público em seu dinamizador; operando com base na 'oferta'. O orçamento público devia ser o dinamizador da oferta, promovendo obras (atividade econômica) que gerariam empregos, salários (o que aqui nos interessa), consumidores em suma, e por fim demanda, que por sua vez animaria novas ofertas, arrastando, pois, todo o ciclo econômico. As teses keynesianas têm perdurado ou perduram, não obstante seus críticos, que não souberam oferecer até hoje uma alternativa que não a do neoliberalismo mais pessimista que se conhece". VIDA SORIA, José et al. op. cit., p. 31-32 (tradução do original, em espanhol).

${ }^{293}$ Trata-se de marco histórico unânime na doutrina mais abalizada, a conferir: i) VIDA SORIA, José et al. op. cit., p. 31; ii) MARTINS, Sérgio Pinto. Direito da seguridade social, cit., p. 5; iii) BELTRAN, Ari Possidonio. op. cit., p. 62; iv) IBRAHIM, Fábio Zambitte. op. cit., p. 47.

294“'O Social Security Act (1935), como parte das medidas adotadas pelo Presidente Franklin D. Roosevelt contra a miséria deixada pela crise econômica de 1929, criava um seguro por velhice e por morte, em favor dos trabalhadores assalariados, previa auxílio financeiro aos Estados que organizassem um sistema de indenização por desemprego na forma fixada pela lei, e dispunha várias medidas assistenciais em favor das categorias menos favorecidas, independentemente de sua condição profissional (deficientes visuais, idosos, viúvas, crianças portadoras de deficiência). O combate à miséria por meio de diversas prestações de seguro e assistência, organizadas de modo sistemático, constituem relevante evolução no processo de proteção social”. ROCHA, Daniel Machado da; SAVARIS, José Antonio. op. cit., v. 1, p. 48-49.

${ }^{295}$ Sobre o Plano Beveridge, e como ele moldou as principais características e princípios dos sistemas modernos e atuais de seguridade social, confiram-se: i) CONCEIÇÃO, Apelles J. B. op. cit., p. 48-49; ii) IBRAHIM, Fábio Zambitte. op. cit., p. 48-51; iii) VIDA SORIA, José et al. op. cit., p. 32-33; iv) CASTRO, Carlos Alberto Pereira de; LAZZARI, João Batista. op. cit., p. 13-15.
} 
constituição e no surgimento de um sistema estatal protetivo do trabalhador nas diversas situações de necessidade econômica decorrentes de infortúnios ${ }^{296}$.

Suas características essenciais foram assim descritas por Sérgio Pinto Martins:

O Plano Beveridge, de 1941, da Inglaterra, também veio a propor um programa de prosperidade política e social, garantindo ingressos suficientes para que o indivíduo ficasse acobertado por certas contingências sociais, como a indigência, ou quando, por qualquer motivo, não pudesse trabalhar. Lord Beveridge dizia que a segurança social deveria ser prestada do berço ao túmulo (Social security from the cradle to the grave). O Plano Beveridge tinha por objetivos: (a) unificar os seguros sociais existentes; (b) estabelecer o princípio da universalidade, para que a proteção se estendesse a todos os cidadãos e não apenas aos trabalhadores; (c) igualdade de proteção; (d) tríplice forma de custeio, porém com predominância do custeio estatal. O Plano Beveridge tinha cinco pilares: (a) necessidade; (b) doença; (c) ignorância; (d) carência (desamparo); (e) desemprego. Era universal e uniforme. Visava ser aplicado a todas as pessoas e não apenas a quem tivesse contrato de trabalho, pois o sistema de então não atingia quem trabalhava por conta própria. Isso dava a ideia da universalidade do sistema. Tinha por objetivo abolir o estado de necessidade. Objetivava proporcionar garantia de renda às pessoas, atacando a indigência. Já pensava no argumento da longevidade do homem e na diminuição da natalidade. Assim, deveria ser adiada a idade da aposentadoria. Deveria haver amparo à infância e proteção à maternidade. Os princípios fundamentais do sistema eram: horizontalidade das taxas de benefícios de subsistência, horizontalidade das taxas de contribuição, unificação da responsabilidade administrativa, adequação dos benefícios, racionalização e classificação ${ }^{297}$.

Pode-se afirmar, pois, que a evolução histórica dos sistemas de proteção estatal social ao trabalhador em face de infortúnios impossibilitadores de seu sustento financeiro se deu em um caminho também de universalização, de ampliação da proteção estatal, tanto em termos de pessoas abarcadas quanto em termos de infortúnios cobertos, do

\footnotetext{
${ }^{296}$ Trata-se do famoso: “(...) Relatório Beveridge, realizado em 1941-1942 sob encomenda do governo britânico e na intenção de se apontar como a Inglaterra deveria ser reconstruída após a II Guerra Mundial, que se observam os princípios que devem nortear a estruturação do encomendado sistema de seguridade social:

a) a seguridade social deve proteger toda população da totalidade dos riscos sociais;

b) as prestações devem ser fixadas em valor uniforme que corresponda ao suprimento das necessidades vitais, sem prejuízo do complemento advindo dos esforços de previdência;

c) o financiamento da seguridade social se dá pelos impostos, no que diz respeito aos abonos de família e ao tratamento de saúde, e pelas contribuições no que tange às demais prestações;

d) a gestão da seguridade social é confiada a um serviço público único, sob autoridade do Ministério da Seguridade Social;

e) essas medidas deveriam ser complementadas por uma política de pleno emprego e por uma política sanitária, sugerindo a criação de um serviço nacional de saúde, financiado pelos impostos de maneira a assegurar a gratuidade no atendimento a toda população, seja pelo ângulo do tratamento, seja pelo ângulo da prevenção". ROCHA, Daniel Machado da; SAVARIS, José Antonio. op. cit., v. 1, p. 49.

${ }^{297}$ MARTINS, Sérgio Pinto. Direito da seguridade social, cit., p. 6.
} 
mesmo modo que se deu com a evolução dos próprios direitos humanos fundamentais, inclusive, sociais ${ }^{298}$.

Assim é que, de uma realidade na qual cada indivíduo era responsável pela própria organização de seus meios de sobrevivência no caso de ocorrência de eventos infortunísticos, passou-se a um incipiente e restrito regime protetivo, privado/contratual, fulcrado nos seguros privados e nos contratos de mútuo, evoluindo para a criação de um sistema protetivo estatal, primeiramente mais restrito e compartimentado, dividido por categoria profissional, ainda sob forte influxo do regime securitário, culminando no atual, moderno, abrangente e universalizante regime estatal protetivo de seguridade social, a abarcar todos os trabalhadores e miseráveis (união entre previdência e assistência social, e a proteção à saúde, em um regime jurídico único ${ }^{299}$ ).

As diferenças marcantes entre os regimes de seguro social e de seguridade social ${ }^{300}$ são, basicamente, as seguintes: i) regime "bismarckiano" de seguro social = caráter mais restrito, englobando basicamente os trabalhadores formais empregados; regime contributivo de capitalização pessoal; proteção de poucas necessidades sociais; ii) regime "beveridgeano" de seguridade social = caráter universal; regime contributivo de repartição única, com financiamento por toda a sociedade; proteção de várias necessidades sociais, com tendência à universalidade de atendimento ${ }^{301}$.

\footnotetext{
${ }^{298}$ Remeto o leitor para as afirmações contidas nos capítulos iniciais, notadamente 1 e 2 , desta obra, onde procurei demonstrar o processo evolutivo de universalização dos direitos humanos fundamentais, inclusive sociais, dos quais o direito à previdência social é espécie integrante.

299،"Renunciando aqui à descrição detalhada do novo sistema, para efeitos deste Manual pode ser proveitoso recordar suas características básicas: - a universalidade e a generalização de certas prestações (notadamente a de saúde); - a uniformização e a predeterminação das prestações de Seguridade Social (elemento este sempre esquecido), e - a inclusão, em um Sistema único, de medidas de Previdência social, modernizada, e outro de Assistência, que desempenharia um papel residual. Todo ele dentro das competências básicas do Estado central”. VIDA SORIA, José et al. op. cit., p. 32-33 (tradução do original, em espanhol).

300،Existem, pois, dois modelos fundamentais de proteção social, que coexistem no Estado Contemporâneo após a Segunda Guerra Mundial, ambos, todavia, baseados no ideal de solidariedade e na intervenção do Estado no domínio econômico, diferenciando-se quanto à parcela da população destinatária e aos limites da participação do Estado no sistema de proteção: 'Um sistema previdenciário cuja característica mais relevante seja a de funcionar como um seguro social pode ser designado como Bismarckiano. Um sistema que enfatize funções redistributivas, objetivando também a redução da pobreza pode ser qualificado por Beveridgeano"'. CASTRO, Carlos Alberto Pereira de; LAZZARI, João Batista. op. cit., p. 15. Para maior aprofundamento sobre o assunto, confira-se: HORVATH JÚNIOR, Miguel. op. cit., p. 22-23.

301“No modelo bismarkiano, mais primitivo, a proteção não era universal, geralmente limitada aos trabalhadores, rigoroso financiamento por meio de contribuições sociais dos interessados (trabalhadores e empresas), além de restringir sua ação a determinadas necessidades sociais. O modelo beveridgiano tem concepção mais ampla, pois visa a universalidade de atendimento, atendendo a tudo e a todos, com financiamento por meio de impostos, arrecadados de toda a sociedade. Percebe-se, claramente, que a solidariedade é mais forte neste modelo”. IBRAHIM, Fábio Zambitte. op. cit., p. 51.
} 
Tal evolução culminou com a formatação do modelo do Estado de Bem-estar Social, ou Welfare State, dominante entre as décadas de 50 a 70 , e que atualmente se encontra em grave crise de sustentabilidade econômica, fruto, dentre outros fenômenos, dos processos de envelhecimento populacional, da redução da taxa de natalidade e da relação entre o número de trabalhadores ativos e inativos, fazendo com que cada vez menos pessoas acabem por sustentar economicamente os benefícios e prestações estatais de previdência social de um contingente cada vez maior. Prestações essas custosas por natureza.

$\mathrm{Na}$ atual quadra da evolução histórica, dentro do Estado Social Democrático de Direito, porém com um certo refluxo dos ideais de proteção dos direitos sociais pelo retorno do liberalismo econômico, agora sob a roupagem do neoliberalismo, o que existe é um embate entre os dois modelos de proteção estatal social aos infortúnios, com a realização de reformas constitucionais em diversos países ao redor do globo na busca de um modelo híbrido, que seja um pouco menos abrangente, mais contributivo e voltado à busca do equilíbrio financeiro e atuarial ${ }^{302}$. Ademais, desenvolve-se um parcial processo de privatização da proteção social aos trabalhadores e necessitados, cujo maior exemplo foi (e é) o surgimento e desenvolvimento dos modelos de previdência privada complementar ${ }^{303} 304$.

O Brasil ${ }^{305}$ seguiu, embora tardiamente, a tendência mundial.

Assim é que, de uma origem privada e voluntária, com a proliferação de fundos mútuos criados dentro do mesmo regime português das misericórdias, a proteção social aos

\footnotetext{
302“Ao que tudo indica, o modelo bismarkiano temperado, com amplitude de cobertura, mas fiel respeito aos preceitos atuariais, ganhará o embate mundial. Especialmente no Brasil, este parece o caminho natural, pois nosso sistema já é, preponderantemente, bismarkiano.” IBRAHIM, Fábio Zambitte. op. cit., p. 54.

${ }^{303}$ Trata-se de uma realidade muito bem captada por Castro e Lazzari: “As chamadas 'reformas' dos sistemas previdenciários públicos obedecem, em síntese, a dois moldes, segundo a classificação de Carmelo MesaLago: (1) reformas estruturais, que visam modificar radicalmente o sistema público, seja introduzindo um componente privado como complemento ao público, seja criando um sistema privado que concorra com o público; e (2) reformas não estruturais, ou paramétricas, que visam melhorar um sistema público de benefícios a fim de fortalecê-lo financeiramente a longo prazo, por exemplo, incrementando a idade de aposentadoria ou o valor das contribuições, ou ainda tornando mais exata a fórmula de calcular o benefício". CASTRO, Carlos Alberto Pereira de; LAZZARI, João Batista. op. cit., p. 17.

${ }^{304}$ Para maior aprofundamento, confira-se: i) VIDA SORIA, José et al. op. cit., p. 36-41; ii CONCEIÇÃO, Apelles J. B. op. cit., p. 58-59. Interessante abordagem acerca do direito à previdência social como direito humano fundamental, porém, com as dificuldades e obstáculos decorrentes do processo de envelhecimento populacional, é dado por: NASSAR, Elody Boulhosa. Previdência social na era do envelhecimento. São Paulo: Saraiva, 2013.

${ }^{305}$ Para maior aprofundamento acerca da evolução histórica da proteção aos infortúnios no Brasil, confiramse: i) CASTRO, Carlos Alberto Pereira de; LAZZARI, João Batista. op. cit., p. 37-54; ii) MARTINEZ, Wladimir Novaes. Curso de direito previdenciário. 6. ed. São Paulo: LTr, 2014. p. 276-293; iii) BELTRAN, Ari Possidonio. op. cit., p. 65-68; iv) ROCHA, Daniel Machado da; SAVARIS, José Antonio. op. cit., v. 1, p. 51-101.
} 
trabalhadores evoluiu para o modelo de seguro social, com destaque para a criação de diversos socorros mútuos, ao longo do século XIX, e das caixas de aposentadorias e pensões, já no início do século XX.

A primeira lei instituidora de um regime de proteção estatal social para os trabalhadores foi a Lei Eloy Chaves, de 24 de janeiro de 1923 (Decreto Legislativo n. 4.682), considerada o marco inicial da previdência social no Brasil.

A partir de então proliferaram os institutos de classe no País, voltados à criação de regimes de proteção social em favor dos integrantes de cada categoria profissional, sendo o IAPM o primeiro deles (Instituto de Aposentadoria e Pensões dos Marítimos), seguido de vários outros ${ }^{306}$.

Em nível constitucional, foi a Constituição Republicana de 1891 a primeira a trazer disposição expressa relacionada à proteção estatal social, garantidora de aposentadoria por invalidez aos servidores públicos (art. 75).

Já a Constituição de 1934 foi a primeira a trazer a forma tripartite de custeio do então regime de seguro social brasileiro: contribuição dos trabalhadores, dos empregadores e do Poder Público (art. 121, $\left.\S 1^{\circ}, h\right)$.

A Constituição de 1946 foi a primeira a tentar sistematizar um regime de previdência social, como direito humano fundamental social, mediante normas jurídicas arroladas ao longo do seu artigo 157.

Com a Constituição de 1967 e Emenda Constitucional n. 01/69 surge um regime de previdência social propriamente dito, unificando-se os diversos Institutos de Aposentadoria e Pensões então existentes (IAP's), sob a batuta do Estado brasileiro, via União Federal, por meio de uma autarquia federal criada sob o nome de INPS - Instituto Nacional de Previdência Social.

No mesmo período são criados o seguro-desemprego e o Seguro de Acidentes do Trabalho (SAT).

Por fim, e na atual quadra do desenvolvimento normativo constitucional de nosso regime protetivo, a Constituição de 1988 evolui para o estágio máximo de proteção,

\footnotetext{
${ }^{306}$ IAPC - Instituto de Aposentadoria e Pensões dos Comerciários; IAPB - Instituto de Aposentadoria e Pensões dos Bancários; IAPI - Instituto de Aposentadoria e Pensões dos Industriários; IPASE - Instituto de Previdência e Assistência dos Servidores do Estado; IAPTC - Instituto de Aposentadoria e Pensões dos Empregados em Transportes e Cargas.
} 
mediante a criação de um sistema de seguridade social, voltado à máxima proteção possível dos direitos humanos fundamentais sociais à assistência, à previdência social e à saúde.

Também é criado o INSS (Instituto Nacional do Seguro Social), em substituição ao INPS, como autarquia federal responsável pela administração do regime de previdência social inaugurado em 1988.

Tal regime constitucional tem suas características principais fixadas já no seu artigo 194, caput, que assim prescreve:

A seguridade social compreende um conjunto integrado de ações de iniciativa dos Poderes Públicos e da sociedade, destinadas a assegurar os direitos relativos à saúde, à previdência e à assistência social.

A abrangência, forma de custeio, beneficiários, infortúnios cobertos, bem como mecanismos de efetivação e implementação de tal regime também aparecem em normas jurídicas constitucionais, espraiadas ao longo dos artigos 194 a 204, da Constituição, tornando nosso regime constitucional um dos mais completos e abrangentes atualmente vigentes ao redor do globo.

A definição acima, trazida pelo constituinte originário, bem traduz uma separação que deve estar presente desde o início para efeitos de análise do objeto de estudo do presente trabalho ${ }^{307}$ : o direito humano fundamental social à previdência social, na atualidade, é garantido mediante um intrincado, complexo e abrangente sistema de proteção estatal que engloba, outrossim, os direitos humanos fundamentais sociais à assistência social e à saúde. Tal sistema possui o nome de seguridade social.

É fruto, conforme já evidenciado, de um longo processo evolutivo histórico, como resultado de inúmeras e intensas lutas pelo reconhecimento dos trabalhadores e miseráveis como sujeitos de direitos, bem como do processo de sacralização da pessoa humana, que culminam com seu reconhecimento normativo, em nível constitucional, pelos Estados soberanos, os quais passam a atuar de forma positiva, interventiva nas sociedades, mediante a criação e desenvolvimento de regimes protetivos dos infortúnios impossibilitadores da manutenção financeira pelos trabalhadores.

\footnotetext{
307، Pressupondo diferenças entre seguridade e previdência, pelo menos em termos constitucionais, esta última espécie daquela, acolhe-se também a versão consoante a qual a primeira é técnica derivada, por via de evolução, da segunda". MARTINEZ, Wladimir Novaes. Curso de direito previdenciário, cit., p. 17.
} 
Trata-se de um caminho inegavelmente universalizante, voltado à busca da maximização da proteção, de sua maior efetividade possível, o que vem ao encontro de tudo o que restou defendido nos capítulos introdutórios deste trabalho.

Logo, todos os mecanismos garantidores de direitos humanos fundamentais sociais já analisados nos capítulos anteriores devem aqui ser aplicados, o que me leva a uma única conclusão possível: no atual estágio do desenvolvimento humano, não há mais espaço para retrocessos sociais em termos de proteção previdenciária. O regime de seguridade social é o único caminho possível em termos de proteção estatal aos infortúnios incapacitantes em termos de sustento financeiro dos trabalhadores, de modo que o retorno a regimes como o do seguro social, ou, pior, securitários privados, encontra óbices intransponíveis nas diversas ordens constitucionais atualmente vigentes, bem como em tratados e convenções internacionais, altamente protetivos do direito à previdência social como direito humano fundamental social, verdadeira cláusula pétrea constitucional.

Tais conclusões serão melhor explicitadas e justificadas a partir de agora, quando passo a analisar o conceito, a natureza jurídica e dois elementos basilares do direito humano fundamental à previdência social.

\subsection{Conceito e natureza jurídica}

Antes de entrar propriamente no conceito de direito humano fundamental à previdência social, é de se salientar que, na atual quadra, ainda permanece disputa doutrinária acerca da correta nomenclatura a ser dada a tal direito: direito à previdência social, direito à seguridade social ou direito à segurança social?

De um lado, os adeptos do termo "seguridade social", tradução mais fiel do social security act, lei editada por Roosevelt nos Estados Unidos da América em 1935, considerada por muitos como origem do atual e moderno sistema protetivo do trabalhador contra os infortúnios inviabilizadores de sua manutenção pelo labor ${ }^{308}$. Trata-se, ademais, de nomenclatura consagrada na maioria dos países europeus ${ }^{309}$.

\footnotetext{
${ }^{308}$ Confira-se, a propósito: i) MARTINS, Sérgio Pinto. Direito da seguridade social, cit., p. 20-21; ii) IBRAHIM, Fábio Zambitte. op. cit., p. 5; iii) HORVATH JÚNIOR, Miguel. op. cit., p. 111-113.

${ }^{309}$ Para a utilização da expressão "seguridad social” na Espanha, confira-se: VIDA SORIA, José et al. op. cit., p. 21-24.
} 
Por outro lado, e lembrando que a tradução correta, para o português, da expressão inglesa security é 'segurança', e não seguridade, tem-se a expressão "segurança social", consagrada em Portugal ${ }^{310}$.

Por fim, existem os defensores da expressão "previdência social”, seja porque se trata de expressão há muito cunhada e consagrada na doutrina, pátria ${ }^{311}$ e estrangeira, seja porque não se pode confundir o direito humano fundamental com suas técnicas de operacionalização, de efetivação ${ }^{312}$.

Reiterando a advertência já feita no início, tenho que não se pode confundir o direito humano fundamental com o seu sistema vigente de proteção e efetivação.

$\mathrm{Na}$ atualidade, o direito humano fundamental de segunda dimensão à previdência social tem como principal sistema de efetivação o de seguridade social, de caráter inegavelmente universalizante, o qual engloba, na verdade, três direitos humanos fundamentais imbricados entre si: previdência social, saúde e assistência social.

Para que não pairem dúvidas, evitando-se a utilização de uma mesma expressão tanto para o direito humano fundamental quanto para o sistema protetivo, o que levaria (e leva) a uma série de desentendimentos e confusões terminológicas, prefiro a utilização da expressão previdência social para se referir ao direito humano fundamental.

Expressão, ademais, que evita a indevida absorção, pelo direito à previdência social, dos dois outros direitos humanos fundamentais de igual relevo e importância: direito à saúde e à assistência social.

Tal foi a escolha feita pelo legislador constituinte pátrio, ao arrolar, no seu artigo $6^{\circ}$, os seguintes direitos humanos fundamentais sociais: "são direitos sociais (...) a saúde, (...), a previdência social, (...) a assistência aos desamparados, (...)".

Logo, tem-se três direitos humanos fundamentais sociais protegidos por um sistema jurídico único (seguridade social), altamente protetivo e universalizante, o que somente reforça a necessidade de utilização de expressões que não confundam ou absorvam cada um desses direitos.

\footnotetext{
${ }^{310}$ CONCEIÇÃO, Apelles J. B. op. cit., p. 21-22.

${ }^{311}$ Este é o caso de MARTINEZ, Wladimir Novaes. Curso de direito previdenciário, cit., p. 17.

${ }^{312}$ Confiram-se, a propósito: i) DIAS, Eduardo Rocha; MACÊDO, José Leandro Monteiro de. op. cit., p. 2944; ii) ROCHA, Daniel Machado da; SAVARIS, José Antonio. op. cit., v. 1, p. 21-28; iii) ROCHA, Daniel Machado da; BALTAZAR JÚNIOR, José Paulo. Comentários à Lei de benefícios da previdência social. 7. ed. Porto Alegre: Livr. do Advogado, 2007. p. 27.
} 
Por decorrência, parece-me que a melhor expressão para se referir ao ramo do direito voltado à proteção e efetivação de tal direito humano fundamental é "Direito Previdenciário".

Quanto ao seu conceito atual, há que se levar em conta: i) a evolução histórica experimentada, com raízes no direito ao trabalho e como decorrência lógica do mesmo; ii) o inegável caráter universalizante da proteção, que ao longo do tempo tem alcançado cada vez mais sujeitos como seus beneficiários; iii) o caráter prestacional e custoso das proteções previstas, substitutivas da remuneração dos participantes; iv) a necessária gerência do sistema por parte do Estado, único capaz de se organizar de molde a garantir um regime protetivo altamente complexo, gigantesco em termos de órgãos de atuação, extensão territorial, capilaridade e variedade de prestações garantidas; v) o seu caráter securitário, ou seja, voltado à garantia de prestações estatais no caso de ocorrência futura de infortúnios inviabilizadores da manutenção financeira do participante por suas próprias forças; vi) o seu caráter obrigatório em termos de participação e ajuda no custeio do sistema protetivo (solidariedade).

A partir de tais características, pode-se conceituar ${ }^{313} \mathrm{o}$ direito à previdência social como $^{314}$ :

\begin{abstract}
direito humano fundamental de segunda dimensão, voltado à garantia de sustento financeiro minimamente digno aos participantes contribuintes e familiares dependentes no caso de ocorrência de determinados infortúnios, previamente fixados em lei, por meio de variadas prestações estatais também previamente fixadas em lei, materializadas e pagas por meio de um sistema jurídico protetivo único, gerido pelo Estado, de participação obrigatória e fulcrado na solidariedade.
\end{abstract}

Já a sua essência é muito bem sintetizada por DIAS e MACÊDO:

Pode-se afirmar, de acordo com a noção acima exposta, que as medidas de previdência, genericamente, têm os seguintes elementos caracterizadores: a proteção (precaução contra infortúnios), diante de contingências (eventos

\footnotetext{
${ }^{313}$ Conceito lapidar e completo é dado por ROCHA e SAVARIS: "Concluindo o presente tópico, conceituamos proteção social como um conjunto de políticas públicas orientadas a assegurar, a todas as pessoas e na medida de suas necessidades, reais condições para que tenham uma existência humana digna, possam desfrutar da participação social e, neste contexto, busquem o livre desenvolvimento de sua personalidade. Os direitos de proteção social se satisfazem mediante prestação de serviços sociais, regulamentação do mercado de trabalho e pagamento de prestações pecuniárias que se tornam devidas sempre quando verificadas as contingências percebidas, em determinado momento histórico e cultural, como socialmente adversas à realização daqueles objetivos fundamentais". ROCHA, Daniel Machado da; SAVARIS, José Antonio. op. cit., v. 1, p. 24-25.

${ }^{314}$ Trazendo um apanhado de conceitos doutrinários pátrios acerca do "direito previdenciário" (ramo do direito) e direito à "previdência social" (direito humano fundamental social), confira-se: MARTINEZ, Wladimir Novaes. Curso de direito previdenciário, cit., p. 17-19 e 296-299.
} 
futuros que podem atingir o ser humano), a fim de debelar necessidades (carência ou escassez do que se precisa para viver) ${ }^{315}$. (grifado)

De se observar que o conceito aqui proposto dá ênfase ao direito em si, e não ao sistema jurídico protetivo que o materializa, que o efetiva, inversão esta levada a cabo pelos doutrinadores defensores da nomenclatura direito à "seguridade social"316 317 .

De qualquer sorte, a identidade de elementos integrantes de ambos os conceitos apresentados demonstra que a celeuma doutrinária acerca da nomenclatura mais útil e científica a ser utilizada para o direito humano fundamental à proteção social estatal em razão da ocorrência de infortúnios não guarda tanto relevo, não tendo prejudicado sua evolução doutrinária.

Já a sua natureza jurídica de direito público subjetivo é inegável, decorrente do fato de o direito à previdência social constituir direito humano fundamental social, garantido e efetivado pelo Estado soberano ${ }^{318}$. Daí decorre que o direito previdenciário é

\footnotetext{
${ }^{315}$ DIAS, Eduardo Rocha; MACÊDO, José Leandro Monteiro de. op. cit., p. 30.

316“Direito da Seguridade Social é o conjunto de princípios, regras e de instituições destinado a estabelecer um sistema de proteção social aos indivíduos contra contingências que os impeçam de prover as suas necessidades pessoais básicas e de suas famílias, integrado por ações de iniciativa dos Poderes Públicos e da sociedade, visando assegurar os direitos relativos à saúde, à previdência e à assistência social". MARTINS, Sérgio Pinto. Direito da seguridade social, cit., p. 21.

${ }^{317}$ Trazendo um apanhado de conceitos doutrinários pátrios acerca do direito à seguridade social, confira-se: HORVATH JÚNIOR, Miguel. op. cit., p. 111-115. Para alguns conceitos estrangeiros, notadamente portugueses e espanhóis, confira-se: CONCEIÇÃO, Apelles J. B. op. cit., p. 28. Conceito consagrado é dado por Jose Manuel Almansa Pastor na obra Derecho de la seguridad social. 7. ed. Madrid: Tecnos, 1991. p. 63-64 (tradução do original, em espanhol): "Em vista do exposto, pode-se considerar a seguridade social, a partir de uma perspectiva jurídica, como o instrumento estatal específico protetor de necessidades sociais, individuais e coletivas, a cuja proteção preventiva, reparadora e recuperadora os indivíduos possuem direito, na extensão, limites e condições que as normas disponham, conforme permita sua organização financeira".

318“Como se sabe, os direitos sociais, como direitos de prestação, podem ter uma vertente subjetiva, como direito individual do cidadão, exigível ante todas as instâncias jurídicas, e não apenas as judiciais; e outra objetiva ou institucional, que pressupõe para sua atualização uma complexa trama organizatória e procedimental. A partir desta perspectiva, a Seguridade Social pode ser entendida tanto como direito subjetivo dos cidadãos, desde o texto constitucional e sem necessidade de se esperar qualquer texto legal, no qual efetivamente se prescreve como tal, quanto como uma 'missão de Serviço Público' do Estado, o que (em pura técnica jurídico-constitucional e administrativa) não é o mesmo que uma 'função do Estado', como quis afirmar em alguma ocasião o Tribunal". VIDA SORIA, José et al. op. cit., p. 52 (tradução do original, em espanhol). De se recordar, ademais, os ensinamentos contidos nos capítulos anteriores desta obra, onde se demonstrou a inserção do direito à previdência social dentre os direitos humanos fundamentais sociais (capítulos 2 e 3 ), bem como a natureza jurídica de direito público subjetivo por parte destes (capítulos 4 e 5), com todos os mecanismos garantidores de sua efetivação, além de seu caráter objetivo, institucional, reforçado por SIMM, Zeno. Os direitos fundamentais e a seguridade social. São Paulo: LTr, 2005. p. 115-118.
} 
parte integrante do ramo do Direito Público, sofrendo todo o seu influxo em termos de regime jurídico ${ }^{319}$.

\subsection{Dois elementos fundantes do direito à previdência social}

Imprescindível o estudo mais detido, agora, de dois elementos básicos e intrínsecos à noção de direito à previdência social ${ }^{320}$, sem os quais não é possível a correta e completa compreensão do direito humano fundamental social em termos de seu sentido e alcance: i) contingência social; ii) princípio da solidariedade social.

\subsubsection{Contingência social}

A expressão contingência social serve para designar os eventos infortunísticos eleitos pelo legislador ${ }^{321}$ (no caso brasileiro, pelo constituinte, conforme art. 201, incisos I a V, da Constituição) como hábeis a gerar o direito à percepção de uma dada prestação positiva estatal, notadamente de cunho financeiro, em favor daqueles filiados ao regime jurídico protetivo.

Trata-se de eventos futuros, de ocorrência incerta ou não, mas que, uma vez ocorridos, deflagram o direito público subjetivo dos participantes do regime à obtenção de certa prestação estatal ${ }^{322}$.

\footnotetext{
${ }^{319}$ Confiram-se, a propósito: i) MARTINS, Sérgio Pinto. Direito da seguridade social, cit., p. 25-29; ii) MARTINEZ, Wladimir Novaes. Curso de direito previdenciário, cit., p. 27-28.

${ }^{320}$ Por se tratar de trabalho voltado ao estudo dos benefícios previdenciários por incapacidade, faço aqui um corte metodológico e deixo de analisar os princípios fundamentais da seguridade social como um todo (englobadora dos direitos à previdência, à assistência e à saúde) arrolados no artigo 194, § único, da Constituição.

${ }^{321}$ Sobre a necessidade de sua prévia previsão em lei, confira-se: "Tendo em vista a natureza securitária da previdência social, é natural a prévia definição das contingências sociais ensejadoras da proteção previdenciária. No seguro privado, a indenização do dano somente se verificará se o evento coberto pelo contrato de seguro se realizar. Na previdência social, a proteção previdenciária só será prestada se o evento legalmente previsto atingir o segurado". DIAS, Eduardo Rocha; MACÊDO, José Leandro Monteiro de. op. cit., p. 51-52.

322“‘́ a ocorrência do evento legalmente previsto que faz nascer o direito subjetivo à proteção previdenciária para o segurado e/ou seu dependente. A seguradora estatal tem obrigação, em abstrato, de proteger o segurado. Em termos concretos, esta obrigação apenas se verifica se ocorrer a contingência legalmente prevista, isto é, se esta se materializar. E pela simples ocorrência do evento, presume a lei que a necessidade terá se instalado para o segurado ou seu dependente. Não há necessidade de comprovar que o evento legalmente previsto efetivamente causou um estado de necessidade. A lei presume que a verificação do evento tem como corolário o estado de necessidade". Id. Ibid., p. 52.
} 
Não se trata do único requisito necessário à obtenção do direito a cada proteção previdenciária, mas, inegavelmente, é seu requisito mais importante, verdadeira razão de ser da prescrição da proteção estatal.

Sua preocupação está na base do próprio surgimento histórico do direito humano fundamental à previdência social, uma vez que, assegurado o direito ao trabalho como conquista civilizatória, tendo os trabalhadores como grupo humano beneficiado, houve a necessidade, imediata, de se garantir proteção no caso da ocorrência de eventos infortunísticos geradores da impossibilidade de manutenção financeira própria e da família pelo labor.

Ou seja, o direito humano fundamental à previdência social surge da necessidade de se garantir uma proteção financeira aos trabalhadores e familiares no caso da ocorrência de eventos geradores da incapacidade para o próprio sustento pela via do labor.

Não é sem razão que os dois primeiros eventos historicamente eleitos pelo legislador como hábeis a gerar a proteção social foram a incapacidade laboral (inclusive pela morte) e a velhice.

Outra questão importante, que deve estar muito bem sedimentada, é aquela atinente à evolução histórica do próprio conceito de contingência social, que evoluiu da concepção originária de seguro, abarcando unicamente eventos futuros e incertos, expandindo sua abrangência para outros eventos, também futuros, mas, de ocorrência certa ou parcialmente certa (p.e.: velhice, maternidade, reclusão).

Assim é que, partindo de uma preocupação securitária, na qual prevalecia a noção de álea, o direito à previdência social evoluiu de seu conceito originário de seguro social para o de contingência social, expandindo sua atuação de modo a abarcar outros eventos futuros, mesmo que de ocorrência certa ou provável, com ênfase na noção de necessidade financeira e social.

$\mathrm{Na}$ atual quadra de evolução, busca-se a expansão da proteção estatal previdenciária para cobrir eventos futuros geradores de necessidades sociais ${ }^{323}$, quais sejam, aqueles

\footnotetext{
${ }^{323}$ Mesmo autores que ainda utilizam a expressão "riscos sociais" para designar tais eventos geradores de necessidades sociais não destoam do conceito e alcance consagrados pela doutrina atual, não obstante eu não concorde com a utilização, atualmente, dessa expressão. Confira-se, a propósito: i) ROCHA, Daniel Machado da; BALTAZAR JÚNIOR, José Paulo. op. cit., p. 29-30; IBRAHIM, Fábio Zambitte. op. cit., p. 27-28; iii) CASTRO, Carlos Alberto Pereira de; LAZZARI, João Batista. op. cit., p. 26; iv) CONCEIÇÃO, Apelles J. B. op. cit., p. 25-27.
} 
inviabilizadores da manutenção própria e familiar pelas próprias forças, sejam eles incertos, ou mesmo certos 324325 .

Conceito de peso para a expressão contingência social ${ }^{326}$ é dado da seguinte forma:

Por contingências se entendem aqueles acontecimentos, possíveis e/ou prováveis, mesmo que dotados de uma relativa incerteza a respeito de sua realização em cada sujeito concreto, mas que, ao ocorrerem, geram uma situação de necessidade a ser protegida socialmente. Suas notas caracterizadoras são, portanto, as seguintes: deve ser um acontecimento possível, porque sem essa possibilidade não surge o sentimento de insegurança; deve ser incerto, é dizer, pode ocorrer ou não, como é o caso do acidente de trabalho ou o desemprego e, de forma mais relativa, os casos da morte ou da maternidade; e é aleatório, no sentido de involuntário por parte da pessoa protegida, como nos casos de doença ou desemprego. Se bem que a existência de voluntariedade não impede a proteção em outros casos como na maternidade ou nas responsabilidades familiares $^{327}$.

Por fim, importante salientar que a necessidade de prévia previsão em lei dos eventos cobertos pela proteção estatal previdenciária faz parte do conceito atual de contingência social, já que se trata de sistema protetivo gerido pelo Estado soberano, não sendo possível a proteção de todo e qualquer evento gerador de necessidade social, mas, unicamente, aqueles previamente previstos, até mesmo para que o sistema guarde o necessário equilíbrio financeiro e atuarial, o que, aliás, é regra constitucional expressa no Brasil (art. 201, caput, da Constituição) ${ }^{328}$.

\footnotetext{
${ }^{324} \mathrm{Tal}$ preocupação aparece de forma flagrante na obra de DIAS e MACÊDO: "O termo 'contingências' para fins de proteção da previdência social deve ser entendido nos seus devidos moldes. A previdência, genericamente, visa à proteção contra riscos, ou seja, eventos futuros e incertos. A previdência social tem por objetivo resguardar o trabalhador das consequências dos eventos que possam atingir a sua atividade laboral. O que é relevante para qualificar tais eventos como merecedores do amparo da previdência social é a sua repercussão econômica na vida do trabalhador. As características de "futuro e incerto" perdem relevância para a previdência social na definição das contingências a serem por ela cobertas. Tudo aquilo que repercutir negativamente na economia do trabalhador deve ser objeto de proteção por parte da previdência social. Mesmo que o evento seja atual, querido e previsto, ainda assim, se abalar a economia do trabalhador, deverá ser alvo de cobertura pela previdência social". DIAS, Eduardo Rocha; MACÊDO, José Leandro Monteiro de. op. cit., p. 31.

${ }^{325}$ Para maior aprofundamento acerca das transformações do conceito e alcance da noção de risco social, evoluindo para a atual concepção de contingência social, confira-se: ZUBA, Thais Maria Riedel de Resende. O direito previdenciário e o princípio da vedação do retrocesso. São Paulo: LTr, 2013. p. 29-41.

${ }^{326}$ Também utilizam tal expressão os seguintes autores: i) MARTINS, Sérgio Pinto. Direito da seguridade social, cit., p. 22; ii) ROCHA, Daniel Machado da; SAVARIS, José Antonio. op. cit., v. 1, p. 23 e 190-191. Já a utilização da expressão risco social, em seu alcance originário, mas, acompanhado das expressões contingência e sinistro, inclusive com o desenvolvimento de tais conceitos e seus respectivos âmbitos de abrangência, como modalidades de eventos cobertos pela previdência social, é encontrado em MARTINEZ, Wladimir Novaes. Curso de direito previdenciário, cit., p. 194-200.

${ }^{327}$ VIDA SORIA, José et al. op. cit., p. 215 (tradução do original, em espanhol).

${ }^{328 ، “} \mathrm{Em}$ todo caso, em que pese a vocação 'universal' também em seu sentido objetivo por parte do artigo 41 $\mathrm{CE}$, resta claro que a Seguridade Social não cobre qualquer risco ou estado de necessidade dos sujeitos incluídos em seu âmbito, senão unicamente aqueles expressamente reconhecidos pelo próprio ordenamento jurídico, com o alcance e os meios também previamente fixados". VIDA SORIA, José et al. op. cit., p. 214 (tradução do original, em espanhol).
} 


\subsubsection{Solidariedade social}

Já o princípio da solidariedade social está na base da própria concepção de previdência social, pois indica a necessidade de que toda a coletividade participe do custeio do regime estatal protetivo ${ }^{329}$.

Trata-se de princípio endereçado, pois, não ao Estado soberano, mas, à própria sociedade, à coletividade integrante da nação, que deve contribuir para que a vida em sociedade seja viável. Engloba os ônus necessários à fruição dos bônus quando em situação de necessidade, de molde a exigir o comprometimento de toda a coletividade em prol da garantia de um sistema protetivo mínimo que beneficie a todos.

Tal característica evidencia o direito humano fundamental à previdência social como verdadeiro pacto transgeracional ${ }^{330}$, pelo qual a geração presente garante o custeio dos benefícios gozados pela geração passada ${ }^{331}$, e assim sucessivamente.

Por isso é correto dizer que tal direito representa a ponte que liga os direitos humanos fundamentais de segunda dimensão (econômicos, sociais e culturais) aos de terceira (transgeracionais), pois possui características de ambas em seu bojo: i) é direito social, prestacional, tendo como maior beneficiário o trabalhador; ii) exige um pacto coletivo em prol de sua manutenção e custeio, de modo que as reservas não são acumuladas individualmente, mas possuem diferentes gerações em cada um dos polos: a geração atual custeando benefícios gozados pela geração passada.

De se concluir, portanto, que o direito humano fundamental à previdência social possui características tanto dos direitos fundamentais de segunda dimensão quanto dos de terceira.

\footnotetext{
329“Sem dúvida, é o princípio securitário de maior importância, pois traduz o verdadeiro espírito da previdência social: a proteção coletiva, na qual as pequenas contribuições individuais geram recursos suficientes para a criação de um manto protetor sobre todos, viabilizando a concessão de prestações previdenciárias em decorrência de eventos preestabelecidos. (...) A solidariedade é a justificativa elementar para a compulsoriedade do sistema previdenciário, pois os trabalhadores são coagidos a contribuir em razão da cotização individual ser necessária para a manutenção de toda a rede protetiva, e não para a tutela do indivíduo, isoladamente considerado.” IBRAHIM, Fábio Zambitte. op. cit., p. 65.

330“Solidariedade social significa a contribuição do universo dos protegidos em benefício da minoria. Precisamos eliminar a ideia de que os benefícios previdenciários só são concedidos a quem está em situação de impossibilidade de obtenção de recursos para sustento pessoal e de sua família, pois isso não corresponde à totalidade das situações. O sistema protetivo visa amparar necessidades sociais que acarretem a perda ou a diminuição dos recursos, bem como situações que provoquem o aumento de gastos. No momento da contribuição, é a sociedade quem contribui; no momento da percepção da prestação, é o indivíduo quem usufrui. Daí vem o pacto de gerações ou princípio da solidariedade entre gerações. Os não necessitados de hoje, contribuintes, serão os necessitados de amanhã, custeados por novos não necessitados que surgem.” HORVATH JÚNIOR, Miguel. op. cit., p. 85.

${ }^{331}$ Adoto, neste trabalho, o momento da contribuição como marco temporal para designar as diferentes gerações em termos de custeio e gozo do regime previdenciário: a geração presente como sendo aquela que ainda está trabalhando, custeando o regime; e a passada, como aquela que já efetuou contribuições pretéritas, mas, que agora se encontra em gozo dos benefícios previdenciários.
} 
Suas raízes históricas remontam à própria Antiguidade, sofrendo, porém enorme influência da Revolução Francesa, na qual restou moldada a noção de fraternidade, último elemento do tripé então plasmado, contendo os grandes objetivos da revolução em prol de toda a humanidade.

Não obstante seu enorme relevo para a previdência social, é certo que o princípio da solidariedade social, por implicar uma visão que privilegia a coletividade em detrimento do indivíduo, passou séculos em verdadeiro ostracismo, ofuscado pelo princípio pilar do liberalismo, qual seja, a liberdade individual, grande mote da própria Revolução Francesa.

Assim é que, dentro de um Estado liberal, em que o princípio da liberdade de atuação atua como pilar fundante, de modo a garantir esferas de atuação livres por parte do particular, no sentido de vedação à atuação estatal, logo, dentro de um binômio particular/Estado, o elemento coletivo, de sociedade, simplesmente não é relevante para a realização das diversas análises, inclusive jurídicas.

Não é sem razão que as duas primeiras dimensões históricas de direitos humanos fundamentais atuam unicamente dentro desta dicotomia indivíduo/Estado: i) a primeira dimensão garante direitos de liberdade, ou seja, impondo obrigações negativas ao Estado (non facere), em prol de cada indivíduo; ii) a segunda dimensão, ao revés, garante a cada indivíduo direitos de igualdade material, notadamente econômicos e sociais, ou seja, impondo obrigações positivas ao Estado (facere).

Em termos históricos, é muito recente o surgimento e desenvolvimento dos direitos de terceira dimensão, nos quais o enfoque se altera, com a agregação do terceiro elemento, fundamental para o estudo desses direitos: a sociedade como sujeito de direitos e deveres.

Não obstante, grandes filósofos do direito já haviam se debruçado sobre o tema, demonstrando a importância da sociedade como sujeito de direitos e deveres, sem o que não seria possível a concepção de modelos estatais viáveis e que levassem ao desenvolvimento da humanidade.

Hegel, em sua obra "Princípios da Filosofia do Direito", ainda no início do século $\mathrm{XIX}^{332}$, dedica toda uma seção para tratar da sociedade civil (Segunda Seção da Terceira Parte, que trata da Moralidade Objetiva; págs. 167/216) ${ }^{333}$.

\footnotetext{
${ }^{332}$ Hegel viveu entre 1770 e 1831 e a versão original da obra data de 1820 .

333“A pessoa concreta que é para si mesma um fim particular como conjunto de carências e como conjunto de necessidade natural e de vontade arbitrária constitui o primeiro princípio da sociedade civil. Mas a pessoa particular está, por essência, em relação com a análoga particularidade de outrem, de tal modo que cada uma se afirma e satisfaz por meio da outra e é ao mesmo tempo obrigada a passar pela forma da
} 
O princípio da universalidade de Hegel equivale ao atual da solidariedade social, presente no artigo $3^{\circ}$, inciso I, da Constituição, como objetivo da República Federativa do Brasil, a moldar a própria concepção de sociedade civil e sua enorme relevância na formatação do modelo de Estado soberano.

Também Léon Duguit, jusfilósofo francês que viveu entre 1859 e 1928, destacou a importância do princípio da solidariedade social como liame universal a ligar toda e qualquer pessoa humana ${ }^{334}$.

Importância fulcral que o fez alçar o princípio da solidariedade social ao patamar de verdadeiro fundamento do direito positivo ${ }^{335}$, a influenciar também a concepção de direito subjetivo, cujos contornos muito se assemelham com aqueles decorrentes da obrigatoriedade da participação no custeio, colocada como regra constitucional em nosso ordenamento jurídico (art. 195, caput, da Constituição):

Estabelecido o direito objetivo na solidariedade social, o direito "subjetivo" daí deriva, direta e logicamente. E sendo todo indivíduo obrigado pelo direito objetivo a cooperar na solidariedade social, resulta que ele tem o "direito" de praticar todos aqueles atos com os quais coopera na solidariedade social, refutando, por outro lado, qualquer obstáculo à realização do papel social que lhe cabe. O homem em sociedade tem direitos; mas esses direitos não são prerrogativas pela sua qualidade de homem; são poderes que lhe pertencem porque, sendo homem social, tem obrigações a cumprir e precisa ter o poder de cumpri-las ${ }^{336}$.

Trata-se, à evidência, de uma concepção de direito, e de direito subjetivo, bastante diversa daquela defendida pelos grandes precursores dos direitos humanos fundamentais como direitos da pessoa humana em sua individualidade (p.e.: Kant), divergindo e muito do percurso histórico percorrido, de forte influência liberal-burguesa.

universalidade, que é o outro princípio. Na sua realização assim determinada pela universalidade, o fim egoísta é a base de um sistema de dependências recíprocas no qual a subsistência, o bem-estar e a existência jurídica do indivíduo estão ligados à subsistência, ao bem-estar e à existência de todos, em todos assentam e só são reais e estão assegurados nessa ligação. Pode começar por chamar-se a tal sistema o Estado extrínseco, o Estado da carência e do intelecto. Nesta divisão de si, a ideia atribui a cada um dos seus momentos uma existência própria: a particularidade tem o direito de se desenvolver e expandir em todos os sentidos e a universalidade tem o direito de se manifestar como fundamento e forma necessária da particularidade bem como potência que a domina e seu fim supremo". HEGEL, Georg Wilhelm Friedrich. Princípios da filosofia do direito. Tradução Orlando Vitorino. São Paulo: Martins Fontes, 2000. p. 167-168.

334“Considerando que grupos sociais sempre existiram e que os homens os integram sem perder a consciência de sua própria individualidade e dos laços de interdependência com os demais, indagamos: Que laços são esses? Eles são designados por uma expressão de largo uso, mas que ainda parece bastante adequada, não obstante o descrédito em que os políticos a lançaram. A "solidariedade social" é que constitui os liames que mantêm os homens unidos”. DUGUIT, León. Fundamentos do direito. Tradução Márcio Pugliesi. 2. ed. São Paulo: Ícone, 2006. p. 22. Para maior aprofundamento, conferir todo o capítulo 6, p. 21-24.

${ }^{335}$ Para maior aprofundamento, confira-se: Id. Ibid., capítulo 7, p. 25-29.

${ }^{336}$ Id. Ibid., p. 27. 
Não obstante, sua importância cada vez maior no atual momento histórico é inegável, quando os direitos humanos fundamentais transgeracionais se encontram em franco desenvolvimento, pressupondo o enfoque sobre a coletividade como sujeito de direitos.

Cenário no qual se encontra inserido o direito à previdência social, em face de seu fundamento filosófico inegável, qual seja, o princípio da solidariedade social, cujas concepções inaugurais e importância foram descortinadas por esses dois grandes filósofos do direito.

De qualquer sorte, a desimportância inicial do princípio da solidariedade social decorrente do modelo de Estado Liberal cedeu passo às conquistas dos trabalhadores obtidas ao longo dos séculos XIX e início do XX, quando, a partir do modelo de Estado Social, e no atual modelo de Estado Democrático e Social de Direito, passa-se a dar cada vez maior atenção ao primado social, em virtude da necessidade de construção de um grande sistema estatal protetivo dos necessitados, para o que resta imperiosa a participação de toda a sociedade 337 .

Por se tratar de um sistema altamente custoso, a participação obrigatória dos cidadãos torna-se condição imprescindível à sua própria existência e manutenção, sendo que sua justificativa basilar reside exatamente no princípio da solidariedade social ${ }^{338} 339$.

Decorrência fulcral do reconhecimento do princípio da solidariedade social como fundamento e pilar do direito humano fundamental à previdência social é o fato de não haver espaço para a adoção de regimes de capitalização individual, sob pena de negação do próprio direito humano fundamental, uma vez que os mesmos pressupõem a individualização do custeio e da prestação dos benefícios, ou seja, exatamente o oposto do

\footnotetext{
${ }^{337}$ Para maior aprofundamento sobre as origens, evolução histórica e conceituação do princípio da solidariedade social, confiram-se: i) NASSAR, Elody Boulhosa. op. cit., p. 270-336; ii) HORVATH JÚNIOR, Miguel. op. cit., p. 84-88; iii) MARTINEZ, Wladimir Novaes. Princípios de direito previdenciário. 5. ed. São Paulo: LTr, 2011. p. 74-88.

${ }^{338}$ Assim é que, na atualidade, há que se entender o princípio da solidariedade social da seguinte forma: "Um ponto sobre o qual convergem os autores é o de que existe uma Solidariedade genérica e uma determinada por um grupo a que pertencemos, com interesses comuns ou interesses comunitários. É essa a Solidariedade, por sua vez, que justifica a cobrança de contribuições sociais relacionadas à Previdência Social (Solidariedade denominada intergeracional). O princípio da Solidariedade genérica pressupõe que o Estado tenha a obrigação de organizar juridicamente a repartição básica da riqueza, aplicando medidas de escoamento mínimo de bens daqueles que são mais abastados para os mais carentes, a fim de garantir a existência digna de todos. É a Solidariedade que justifica a imputação de impostos gerais à sociedade para a realização dos serviços públicos gerais. Já a solidariedade de grupo fundamenta as contribuições incidentes sobre a folha de salários, enquanto o que justifica as contribuições sobre o faturamento e o lucro é a Solidariedade genérica que fundamenta a capacidade contributiva". NASSAR, Elody Boulhosa. op. cit., p. 288.

${ }^{339} \mathrm{Na}$ mesma linha do aqui proposto, confira-se: i) MARTINS, Sérgio Pinto. Direito da seguridade social, cit., p. 58-59; ii) CASTRO, Carlos Alberto Pereira de; LAZZARI, João Batista. op. cit., p. 21-22; iii) ROCHA, Daniel Machado da; SAVARIS, José Antonio. op. cit., v. 1, p. 123-125.
} 
propalado pelo princípio em voga, que pressupõe a participação obrigatória de todos em prol da formação de um fundo global, transgeracional ${ }^{340}$.

Dentro do vigente modelo constitucional brasileiro, tal modificação se afigura impossível, obstada, principalmente, pelos mecanismos de proteção das cláusulas pétreas e da vedação do retrocesso social, a inviabilizar o abandono do modelo de seguridade social como mecanismo de proteção e efetivação dos direitos humanos fundamentais sociais à previdência social, à saúde e à assistência social.

De qualquer sorte, o correto entendimento acerca do direito humano fundamental à previdência social passa, hodiernamente, pelo incremento de importância de seu enfoque à luz do princípio da solidariedade social, ou seja, por um enfoque conjugado e global sob um duplo aspecto: como direito humano fundamental do indivíduo necessitado e como dever de custeio e manutenção por toda a sociedade ${ }^{341}$.

\footnotetext{
340“'Importa ressaltar que os países que, em face de mudanças nos seus regimes previdenciários, adotaram o sistema de capitalização de recursos - mediante contas individualizadas em nome de cada segurado abandonaram, a nosso ver, a noção de 'previdência social', já que esta só se observa quando a sociedade, como um todo, presta solidariedade a cada um dos indivíduos que dela necessitem, por meio do sistema de repartição, ou de fundo único. A partir do momento em que cada trabalhador faça cotizações para si próprio, e não para um fundo mútuo, desaparece a noção de solidariedade social." CASTRO, Carlos Alberto Pereira de; LAZZARI, João Batista. op. cit., p. 22.

${ }^{341}$ Interessante abordagem, crítica do excessivo enfoque individualista da previdência social, logo, denunciador de uma chamada "crise de solidariedade" no Estado brasileiro, com a busca de soluções que passam necessariamente pelo binômio direito individual/dever coletivo, é encontrada em: BAGGIO, Moacir Camargo. Jurisdição e previdência em tempos de crise de solidariedade. São Paulo: LTr, 2008.
} 


\section{DAS CONTINGÊNCIAS SOCIAIS PROTEGIDAS PELO REGIME GERAL DE SEGURIDADE SOCIAL NO BRASIL}

\subsection{Parâmetros gerais}

Centrei meus esforços, até o presente momento, na busca de um arsenal teórico argumentativo fundamentador do direito humano fundamental à previdência social e de seu elevado grau de importância e efetividade jurídica.

A partir de agora, passo a adotar uma abordagem de cunho mais pragmático, analisando as disposições constitucionais garantidoras do direito à previdência social e de seus contornos e limites.

Evidente que a interpretação de tais disposições constitucionais se dará à luz do arsenal teórico desenvolvido nos capítulos introdutórios, o que trará, inexoravelmente, uma nova visão sobre o direito humano fundamental à previdência social, com consequências favoráveis em termos de ganhos na proteção e efetivação de tal direito.

Ademais, a interpretação das disposições constitucionais disciplinadoras do direito humano fundamental à previdência social deverá observar os princípios orientadores da seguridade social expressamente previstos no artigo 194, § único, da Constituição, a saber: $:^{342}$

\footnotetext{
Parágrafo único. Compete ao Poder Público, nos termos da lei, organizar a seguridade social, com base nos seguintes objetivos:

I - universalidade da cobertura e do atendimento;

II - uniformidade e equivalência dos benefícios e serviços às populações urbanas e rurais;

III - seletividade e distributividade na prestação dos benefícios e serviços;

IV - irredutibilidade do valor dos benefícios;

$\mathrm{V}$ - equidade na forma de participação no custeio;

VI - diversidade da base de financiamento;

VII - caráter democrático e descentralizado da administração, mediante gestão quadripartite, com participação dos trabalhadores, dos empregadores, dos
}

\footnotetext{
${ }^{342}$ Não abordarei cada princípio neste estudo, já que o mesmo é voltado ao estudo dos benefícios por incapacidade de forma unitária, dentro de seu regime jurídico balizador único, caracterizador de sua fungibilidade. Não obstante, para maior aprofundamento, sugiro: i) DIAS, Eduardo Rocha; MACÊDO, José Leandro Monteiro de. op. cit., p. 102-111; ii) ROCHA, Daniel Machado da; SAVARIS, José Antonio. op. cit., v. 1, p. 122-136; iii) MARTINS, Sérgio Pinto. Direito da seguridade social, cit., p. 59-67; iv) ROCHA, Daniel Machado da; BALTAZAR JÚNIOR, José Paulo. op. cit., p. 33-40; v) ZUBA, Thais Maria Riedel de Resende. op. cit., p. 67-82.
} 
aposentados e do Governo nos órgãos colegiados. (Redação dada pela Emenda Constitucional $\mathrm{n}^{\circ} 20$, de 1998)

Interessante notar que o próprio legislador constituinte, atento à caracterização dos princípios como verdadeiros mandamentos de otimização ${ }^{343}$, inseriu de forma concomitante no rol de princípios vetores do regime de seguridade social o da universalidade (inciso I), demonstrando o caráter universalizante da proteção social estatal, como objetivo maior a ser perseguido, porém, ao mesmo tempo, o da seletividade $e$ distributividade (inciso III), reconhecendo o caráter altamente custoso do regime, delegando ao legislador ordinário a eleição das contingências sociais a serem protegidas, bem como as prestações a serem disponibilizadas.

Não se trata de antinomia, conforme já exaustivamente demonstrado ao longo do capítulo 4 desta obra, mas da necessidade de realização da interpretação conjunta e conjugada de tais mandamentos, tendo como norte a busca da máxima efetividade possível dentro das possibilidades fáticas e jurídicas existentes.

É de se atentar, ademais, aos princípios específicos da previdência social, cunhados no artigo 201, da Constituição, além daqueles relacionados ao custeio do regime de seguridade social (art. 195, da Constituição).

Por fim, de enorme relevo são aqueles princípios insculpidos nos $\operatorname{artigos} 1^{\circ}$ a $4^{\circ}$, da Constituição, inseridos no Título I, chamado "Dos Princípios Fundamentais", sendo dois deles grandes vetores interpretativos de todas as disposições constitucionais e legais disciplinadoras do direito humano fundamental à previdência social, a saber: i) dignidade da pessoa humana (art. $1^{\circ}$, III, da Constituição); ii) construir uma sociedade livre, justa e solidária (art. $3^{\circ}$, I, da Constituição).

Isso sem falar nas regras constitucionais instrumentais, garantidoras da máxima efetividade aos direitos humanos fundamentais, das quais são exemplos: i) a aplicabilidade imediata das normas definidoras de direitos e garantias fundamentais (art. $5^{\circ}$, I, da Constituição); ii) a vedação de supressão de tais normas, acobertadas que estão pelas chamadas "cláusulas pétreas" (art. $60, \S 4^{\circ}, \mathrm{IV}$, da Constituição).

\footnotetext{
${ }^{343}$ Conceito cunhado por Robert Alexy, conforme já explicitado ao longo do capítulo 4, ao qual remeto o leitor.
} 
De qualquer sorte, conforme já elucidado no capítulo anterior, a pedra de toque para o estudo do direito humano fundamental à previdência social deve ser seu elemento basilar, primário, qual seja, a noção de contingência social.

Ou seja, o estudo jurídico do direito à previdência social deve se dar a partir das contingências sociais previstas pelo legislador constituinte como aptas a gerar a proteção estatal prestacional.

O legislador constituinte, por seu turno, já se encontra previamente vinculado a um standard jurídico mínimo a ser observado em termos de contingências sociais abrangidas pelo regime protetivo estatal.

Trata-se da Convenção n. 102, da Organização Internacional do Trabalho (OIT), aprovada na sua $35^{\mathrm{a}}$ reunião (1952), com início de produção de efeitos em 27.04.1955, aprovada pelo Congresso Nacional brasileiro em 19.09.2008 (Decreto legislativo n. 269) e ratificada pelo chefe do Poder Executivo em 15.06.2009

\subsection{Contingências sociais em espécie}

Tais são as contingências sociais mínimas a serem protegidas pelos Estados membros aderentes: i) serviços médicos (arts. $7^{\circ}$ a 12); ii) auxílio-doença (arts. 13 a 18); iii) prestações de desemprego (arts. 19 a 24); iv) aposentadoria por velhice (arts. 25 a 30); v) prestações em caso de acidentes de trabalho e de doenças profissionais (arts. 31 a 38); vi) prestações de família (arts. 39 a 45); vii) prestações de maternidade (arts. 46 a 52); viii) aposentadoria por invalidez (arts. 53 a 58); ix) pensão por morte (arts. 59 a 64).

O legislador constituinte pátrio, já observando o regramento internacional, fixou as seguintes contingências sociais como geradoras do dever estatal de proteção:

\footnotetext{
Art. 201. A previdência social será organizada sob a forma de regime geral, de caráter contributivo e de filiação obrigatória, observados critérios que preservem o equilíbrio financeiro e atuarial, e atenderá, nos termos da lei, a: (Redação dada pela Emenda Constitucional n ${ }^{\circ} 20$, de 1998)

I - cobertura dos eventos de doença, invalidez, morte e idade avançada; (Redação dada pela Emenda Constitucional nº 20, de 1998)

II - proteção à maternidade, especialmente à gestante; (Redação dada pela Emenda Constitucional nº 20, de 1998)

III - proteção ao trabalhador em situação de desemprego involuntário; (Redação dada pela Emenda Constitucional nº 20, de 1998)
}

\footnotetext{
${ }^{344}$ Consulta realizada em 7.7.2015 junto ao seguinte endereço eletrônico: ORGANIZAÇÃO INTERNACIONAL DO TRABALHO. Disponível em: <http://www.oitbrasil.org.br/node/468>.
} 
IV - salário-família e auxílio-reclusão para os dependentes dos segurados de baixa renda; (Redação dada pela Emenda Constitucional nº 20, de 1998)

$\mathrm{V}$ - pensão por morte do segurado, homem ou mulher, ao cônjuge ou companheiro e dependentes, observado o disposto no $\S 2^{\circ}$. (Redação dada pela Emenda Constitucional no 20, de 1998)

De se observar que, além daquele rol fixado pela Convenção n. 102, da OIT, o constituinte pátrio acrescentou a reclusão como contingência social apta a ensejar proteção estatal aos dependentes do trabalhador segurado ao regime previdenciário, na forma da legislação ordinária.

\subsection{Conclusões}

No caso brasileiro, fixadas as contingências sociais aptas a ensejar a proteção estatal pelo seu legislador constituinte, a forma de abordagem levada a cabo nesta obra permite, desde já, a fixação de algumas importantes conclusões:

1. O legislador ordinário deverá disciplinar e esmiuçar em lei todas as contingências sociais fixadas pelo constituinte, sob pena de incidir em inconstitucionalidade por omissão;

2. É vedado ao constituinte derivado excluir qualquer das contingências sociais do rol constitucional, sob pena de ofensa à garantia da cláusula pétrea (art. $60, \S 4^{\circ}, \mathrm{IV}$, da Constituição) e, por via reflexa, à garantia da vedação do retrocesso social;

3. O legislador ordinário poderá ampliar o rol de contingências sociais fixado pelo constituinte, pois trata-se de um standard mínimo a vincular o Estado;

4. O estudo do direito à previdência social deverá partir da análise das contingências sociais eleitas como aptas a gerar a proteção social estatal, e não das prestações fixadas em lei, como corolário da prevalência das normas constitucionais sobre as legais (supremacia da constituição).

No tocante especificamente à última conclusão supra, é de se salientar que a doutrina previdenciária, nacional e estrangeira, aglutina e classifica as prestações estatais previdenciárias de acordo com alguns critérios, sendo os principais os seguintes: i) quanto ao aspecto pecuniário: benefícios ou serviços; ii) quanto aos destinatários: segurados, 
dependentes ou ambos; iii) quanto ao caráter substitutivo da remuneração (critério aplicável unicamente aos benefícios): substitutivos ou não substitutivos ${ }^{345}$.

O legislador ordinário, ao disciplinar tais prestações, claramente optou pela divisão calcada no critério subjetivo, ou seja, dividiu as prestações com base nos seus destinatários, assim prescrevendo o artigo 18, da Lei n. 8.213/91:

Art. 18. O Regime Geral de Previdência Social compreende as seguintes prestações, devidas inclusive em razão de eventos decorrentes de acidente do trabalho, expressas em benefícios e serviços:

I - quanto ao segurado:

a) aposentadoria por invalidez;

b) aposentadoria por idade;

c) aposentadoria por tempo de contribuição; (Redação dada pela Lei Complementar $\mathrm{n}^{\mathrm{o}} 123$, de 2006)

d) aposentadoria especial;

e) auxílio-doença;

f) salário-família;

g) salário-maternidade;

h) auxílio-acidente;

i) abono de permanência em serviço; (Revogada pela Lei no 8.870 , de 1994)

II - quanto ao dependente:

a) pensão por morte;

b) auxílio-reclusão;

III - quanto ao segurado e dependente:

a) pecúlios; (Revogada pela Lei $n^{\circ} 9.032$, de 1995)

b) serviço social;

c) reabilitação profissional

Não obstante, a meu ver o critério a ser observado na divisão e classificação das prestações previdenciárias deve ser aquele adotado pelo legislador constituinte, aliás, seguindo a orientação fixada pela OIT, qual seja, aquele fulcrado no fato gerador da prestação, na contingência social deflagradora do direito humano fundamental à previdência social.

Trata-se, ademais, de critério muito mais útil e eficaz, pois permite o aglutinamento de diversos benefícios em torno da contingência social equivalente, com enormes ganhos

\footnotetext{
${ }^{345}$ Para maior aprofundamento, confira-se: DIAS, Eduardo Rocha; MACÊDO, José Leandro Monteiro de. op. cit., p. 187-188. Em Portugal, profunda classificação é feita por: CONCEIÇÃO, Apelles J. B. op. cit., p. 150-153.
} 
em termos de efetividade e proteção social, o que será demonstrado nos capítulos seguintes.

Tal aglutinação permite, outrossim, a leitura e interpretação sistemáticas das normas jurídicas disciplinadoras das espécies reunidas de prestação estatal, as quais passam a ser observadas sob o enfoque do regime jurídico disciplinador comum fulcrado na contingência social deflagradora das prestações previdenciárias equivalentes.

De se salientar que tal forma de estudo das prestações estatais previdenciárias já é realidade nos países europeus, do que são exemplos obras de doutrinadores Portugueses ${ }^{346}$ e Espanhóis ${ }^{347}$, nas quais se procura o agrupamento das diversas espécies de prestação previdenciária em categorias comuns, tendo como elemento aglutinador exatamente a contingência social deflagradora do direito à previdência social.

No Brasil, ainda prevalece o estudo no formato literal trazido pelo legislador ordinário no bojo da Lei n. 8.213/91, fincado no elemento subjetivo.

\footnotetext{
${ }^{346}$ Apelles J. B. Conceição, por exemplo, aglutina as prestações previdenciárias nos seguintes grupos: i) prestações contributivas: a) substitutivas de rendimento de trabalho, a englobar: riscos físicos não profissionais (subsídios por adoção, para assistência a deficientes profundos e doentes crônicos, para assistência na doença a descendentes menores ou deficientes, de doença, por faltas especiais dos avós, por licença parental, de maternidade, de paternidade, por riscos específicos, de tuberculose e pensões de invalidez, de velhice, de sobrevivência e unificada) e riscos econômicos (compensação retributiva, garantia salarial, salários em atraso, subsídios de desemprego e de desemprego parcial, subvenção a trabalhadores de empresas paralisadas e trabalhadores da siderurgia e do carvão); b) compensatórias de encargos, a englobar: prestações em geral (abonos de família a crianças e jovens e de família pré-natal, complemento de pensão por cônjuge, reembolso das despesas de funeral, subsídio de funeral, subsídio mensal vitalício e subsídio por morte), por deficiência (bonificação por deficiência e subsídio de educação especial) e por dependência (complemento por dependência e subsídios de acompanhante e por assistência de $3^{\mathrm{a}}$ pessoa); ii) prestações por riscos físicos profissionais: a) em geral; b) por incapacidade, a englobar: indenização por incapacidade temporária para o trabalho, pensão por incapacidade permanente para o trabalho, subsídios por situação de elevada incapacidade permanente, por readaptação de habitação e para frequência de cursos de formação profissional e prestação suplementar à pensão; c) prestações por morte, a englobar: pensão por morte, subsídio por morte e subsídio por despesas de funeral; iii) prestações não contributivas, a englobar: complementos por dependência, extraordinário de solidariedade, regional de pensão (RA Açores), social e solidário para idosos, subsídios por assistência de $3^{\mathrm{a}}$ pessoa, de educação especial e social de desemprego, pensões de orfandade, social e de viuvez e prestação de rendimento social de inserção; iv) prestações da responsabilidade financeira de outras entidades ou fundos, a englobar: antigos combatentes, prestação de alimentos, proteção jurídica e subsídios de gravidez, de lar, de reconversão profissional e de renda de casa. Confira-se, a propósito, em sua obra citada, o Capítulo III, da Parte I ("Relação de Prestação"), CONCEIÇÃO, Apelles J. B. op. cit., p. 169-351.

${ }^{347}$ José Vida Soria, José Luis Monereo Pérez, Cristóbal Molina Navarrete e Rosa Quesada Segura adotam a seguinte aglutinação de prestações em sua obra VIDA SORIA, José et al. Manual de seguridad social, cit., 2011, p. 273-548 (tradução do original, em espanhol): i) o regime jurídico das prestações por incapacidade temporária, maternidade-paternidade e risco, durante a gravidez; ii) as prestações por incapacidade permanente; iii) a proteção à velhice. Proteção por aposentadoria; iv) proteção para as situações decorrentes da morte; v) proteção social à família. As prestações familiares; vi) a proteção ao desemprego; vii) a proteção à saúde como contingência coberta. Prestações de saúde e organização do sistema nacional de saúde; viii) prestações complementares internas de 'ação social' no sistema de seguridade social.
} 
Com a utilização do critério fulcrado nas contingências sociais arroladas pelo legislador constituinte, proponho a seguinte classificação aglutinativa das diversas prestações previdenciárias estatais:

1. Prestações por incapacidade laboral decorrente de doença e invalidez (art. 201, I, da Constituição): aposentadoria por invalidez, auxílio-doença e auxílio-acidente (respectivamente, arts. 42 a 47, 59 a 63 e 86, da Lei n. 8.213/91);

2. Prestações por morte (art. 201, I, da Constituição): pensão por morte (arts. 74 a 79, da Lei n. 8.213/91);

3. Prestações por idade avançada (art. 201, I, da Constituição): aposentadoria por idade, aposentadoria por tempo de contribuição e aposentadoria especial (respectivamente, arts. 48 a 51,52 a 56 e 57 a 58 , da Lei n. 8.213/91);

4. Prestações por maternidade (art. 201, II, da Constituição): salário maternidade (arts. 71 a 73, da Lei n. 8.213/91);

5. Prestações por desemprego involuntário (art. 201, III, da Constituição): seguro desemprego (arts. $2^{\circ}$ a $8^{\circ}$-C, da Lei n. 7.998/90);

6. Prestações para a família (art. 201, IV, da Constituição): salário família (arts. 65 a 70, da Lei n. 8.213/91);

7. Prestações por reclusão (art. 201, IV, da Constituição): auxílio-reclusão (art. 80, da Lei n. 8.213/91);

8. Demais prestações e serviços fixados em lei ordinária (p.e., serviço social, art. 88, da lei n. 8.213/91; habilitação e reabilitação profissional, arts. 89 a 93, da Lei n. 8.213/91; abono salarial, arts. $9^{\circ}$ e $9^{\circ}$-A, da Lei n. 7.998/90).

Observe que, com base na classificação por mim proposta, resta clara a aglutinação das prestações devidas ao segurado em razão do evento deflagrador da incapacidade laboral decorrente de doença ou invalidez, o que leva à fixação de um regime jurídico unificado em prol dessas prestações, com a inexorável conclusão no sentido de que a análise de cada prestação previdenciária inserida em tal rol (aposentadoria por invalidez, auxílio-doença e auxílio-acidente) deverá levar em conta todas as normas jurídicas disciplinadoras das três prestações decorrentes da incapacidade laboral, ou seja, com o reforço das interpretações sistemática e teleológica em prol da máxima efetividade do direito humano fundamental à previdência social nesta seara. 


\section{DA CONTINGÊNCIA SOCIAL DA INCAPACIDADE LABORAL E RESPECTIVOS BENEFÍCIOS PREVIDENCIÁRIOS}

\subsection{Importância prática do tema}

Passo, a partir deste capítulo, a analisar diretamente o objeto do presente estudo, qual seja, os benefícios previdenciários decorrentes da incapacidade laboral gerada pelos eventos de doença ou invalidez, como direito humano fundamental assegurado pelo artigo 201, I, da Constituição, a saber: i) aposentadoria por invalidez; ii) auxílio-doença; iii) auxílio-acidente.

Mas, qual a importância prática de tal estudo?

Reputo importante trazer, neste contexto, algumas estatísticas relacionadas à quantidade de ações judiciais em trâmite junto aos Juizados Especiais Federais da Terceira Região ${ }^{348}$ sobre o assunto.

O quadro comparativo abaixo é bastante esclarecedor acerca da enorme importância que tais benefícios assumiram nos últimos anos, uma vez que o número de ações judiciais buscando a concessão de um dos três benefícios por incapacidade laboral previstos em lei tem crescido anualmente.

Segue, abaixo, quadro comparativo demonstrando o número de ações judiciais distribuídas nos anos de 2013 e 2014 referentes a tais benefícios, bem como o quantitativo de ações em trâmite nos Juizados Especiais Federais da Terceira Região ${ }^{349}$ :

\begin{tabular}{|l|l|l|l|l|}
\hline \multicolumn{4}{|l|}{$\mathbf{2 0 1 3}$} & $\mathbf{2 0 1 4}$ \\
\hline Benefício por incapacidade requerido & tramitação & Distribuídos & tramitação & distribuídos \\
\hline Aposentadoria por invalidez & 26.488 & 26.770 & 29.465 & 28.744 \\
\hline Auxílio-doença & 35.280 & 32.025 & 36.590 & 35.791 \\
\hline Auxílio-acidente & 964 & 1.037 & 1.299 & 1.461 \\
\hline
\end{tabular}

\footnotetext{
${ }^{348}$ Região que abarca os Estados de São Paulo e Mato Grosso do Sul.

${ }^{349}$ Dados extraídos do sistema dos Juizados Especiais Federais da Terceira Região, acessado em 13.07.2015. Os números apresentados são o resultado da somatória do número de feitos existentes em cada Juizado Especial Federal da Terceira Região, uma vez que o sistema não possui a funcionalidade de trazer os dados consolidados no tocante às estatísticas relacionadas à distribuição e tramitação processuais por assunto.
} 
Trata-se, inegavelmente, de um grande acervo processual, bem como uma massa considerável de ações ajuizadas anualmente dentro do sistema dos Juizados Especiais Federais da Terceira Região, o que demonstra a grande importância prática do tema pelo prisma da movimentação da máquina judiciária.

Importância essa que aumenta ainda mais ao se considerar o número de feitos distribuídos em cada ano, proporcionalmente ao número total de feitos distribuídos nos Juizados Especiais Federais da Terceira Região, conforme tabela abaixo:

\begin{tabular}{|l|l|l|l|}
\hline & $\begin{array}{l}\mathbf{N}^{\mathbf{t}} \text { total feitos } \\
\text { distribuídos }\end{array}$ & $\begin{array}{l}\mathbf{N}^{\mathbf{0}} \text { feitos benefícios } \\
\text { por incapacidade }\end{array}$ & Porcentual \\
\hline $\mathbf{2 0 1 3}$ & 187.747 & 59.832 & $31,87 \%$ \\
\hline $\mathbf{2 0 1 4}$ & $304.909^{350}$ & 65.996 & $21,64 \%$ \\
\hline
\end{tabular}

De se observar pelos dados estatísticos que, no ano de 2013, de cada três ações ajuizadas no sistema dos Juizados Especiais Federais da Terceira Região, uma era relacionada a benefícios por incapacidade, porcentual que se reduziu no ano de 2014, mas, de qualquer sorte, correspondendo a uma ação de cada cinco ajuizadas.

Considerando-se a enormidade de teses jurídicas revisionais sabidamente existentes na seara previdenciária, bem como o relativamente grande número de outros benefícios previdenciários existentes, são notórias a força e a importância dos benefícios por incapacidade dentro do regime previdenciário.

Relevância inclusive em termos de movimentação da máquina judiciária federal da Terceira Região dentro do sistema dos Juizados Especiais Federais, não sendo exagero algum se afirmar que os pleitos relacionados aos benefícios por incapacidade são os responsáveis, por assunto, pela maior parte do acervo processual existente e da distribuição anual verificada.

E, considerando-se o incremento entre 2013 e 2014 tanto no número de feitos em tramitação $(7,37 \%)$ quanto no de distribuídos $(10,30 \%)$ relacionados aos benefícios por

\footnotetext{
${ }^{350}$ Grande parte deste colossal incremento no número de ações judiciais distribuídas no sistema dos Juizados Especiais Federais da Terceira Região (62,40\%) deve-se à tese jurídica que busca a modificação do índice de correção monetária dos depósitos de FGTS, pendente de julgamento junto aos Tribunais Superiores (STF por via de Adin e STJ por via de recurso submetido à sistemática dos recursos repetitivos, com efeitos vinculantes).
} 
incapacidade, resta fácil concluir que tal importância tende somente a aumentar, o que justifica o estudo aprofundado e científico ora levado a cabo acerca de tais benefícios.

\subsection{Da contingência social protegida: questão terminológica}

No tocante ao objeto em si deste trabalho, deve ficar claro desde já que a contingência social deflagradora do direito humano fundamental à percepção de um dos três benefícios integrantes desta categoria específica de direito à previdência social não é a doença e/ou a invalidez prescritos literalmente no artigo 201, I, da Constituição, mas sim a incapacidade laboral decorrente de tais eventos.

Uma intepretação literal da disposição constitucional levaria a uma conclusão equivocada no sentido de que bastaria a ocorrência dos eventos de doença e/ou invalidez para que o segurado fizesse jus à prestação estatal, o que não é verdade, pois, conforme já demonstrado nos capítulos 6 e 7, o surgimento e consolidação históricos da previdência social como direito humano fundamental têm como grande preocupação a ocorrência de infortúnios geradores da incapacidade para o trabalho por parte dos trabalhadores.

Assim, a ocorrência de eventos desfavoráveis, porém que não levem à perda da capacidade para o labor, não possui o condão de gerar o direito à percepção de uma prestação estatal dentro da previdência social.

Logo, a contingência social única deflagradora do direito à percepção de um dos três benefícios previdenciários inseridos em uma categoria própria dentro do direito previdenciário é a incapacidade laboral decorrente de doença ou invalidez ${ }^{351}$.

\footnotetext{
${ }^{351}$ Tal constatação restou trazida por Michel Cutait Neto da seguinte forma: "Como se viu, a Constituição não trouxe, expressamente no rol dos incisos do artigo 201, a figura da incapacidade como evento que merecia a proteção social da previdência social. Nem precisava trazer, porque a incapacidade referida aqui é fruto daquilo que se convencionou adotar como primado dentro da ordem social, o trabalho. A incapacidade como risco social é fruto do trabalho, ou, mais precisamente que isso, a incapacidade se refere ao trabalho, à especial situação que retira, suprime, diminui e afeta o exercício do trabalho. (...) Como o risco social da incapacidade para o trabalho pode se manifestar no mundo da vida de várias maneiras, sob vários níveis e gravidades, e em relação a diversos fatos, o legislador constituinte preferiu adotar na Constituição Federal de 1988 um rol mais detalhado, com a identificação mais precisa dos eventos que possam causar gravame ao exercício do trabalho. (...) Pode-se, a partir da especificidade da Constituição Federal, adotar como gênero o evento incapacidade e como espécies três* das quatro situações de necessidade apontadas no inciso I do artigo 201 da Constituição Federal, quer sejam, a doença, a invalidez e a morte”. CUTAIT NETO, Michel. Auxílio-doença. Leme: J.H. Mizuno, 2006. p. 116-117.

*Não obstante o autor faça referência à morte como evento integrante da contingência social da incapacidade laboral, não me parece ser o caso, pois a morte não pode ser considerada evento deflagrador de direito à própria pessoa que falece, que deixa de existir em termos jurídicos (art. $6^{\circ}$, do Código Civil), mas, unicamente em favor de seus dependentes. No caso, a morte é contingência social deflagradora do benefício da pensão por morte, mas não de benefícios por incapacidade (aposentadoria por invalidez, auxílio-doença e auxílio-acidente), cujos eventos integrantes são aqueles outros dois arrolados no trecho supra transcrito, a saber: doença e invalidez.
} 
É por isso que os artigos $42, \S 2^{\text {o352 e } 59, \S \text { único }}{ }^{353}$, da Lei n. 8.213/91, ao tratarem, respectivamente, dos benefícios previdenciários de aposentadoria por invalidez e auxíliodoença, excluem do direito à sua percepção os segurados já portadores de doença ou lesão quando da filiação ao regime geral de previdência social, ressalvando os casos em que a incapacidade laboral sobrevier de progressão ou agravamento das mesmas.

Isso porque é o momento do surgimento da incapacidade laboral o marco temporal relevante juridicamente para efeitos de aplicação da legislação de regência das prestações previdenciárias por incapacidade, como direito humano fundamental social, exatamente porque a contingência social protegida pelo Estado é a incapacidade laboral, decorrente de doença ou invalidez.

Logo, se a pessoa, ao se inscrever no regime geral de previdência social, é portadora de doença ou lesão, porém, que não gera incapacidade laboral, vindo apenas posteriormente a se tornar incapaz para o labor, em razão de progressão ou agravamento da doença ou lesão, possui direito à prestação estatal correspondente, não se lhe aplicando o óbice da doença preexistente.

O que é vedado é a percepção de prestação estatal em decorrência de incapacidade laboral preexistente à filiação.

Isso em razão do caráter securitário do regime de previdência social, bem como de seu caráter obrigatoriamente contributivo, fincado no princípio da solidariedade social ${ }^{354}$.

\footnotetext{
352““A doença ou lesão de que o segurado já era portador ao filiar-se ao Regime Geral de Previdência Social não lhe conferirá direito à aposentadoria por invalidez, salvo quando a incapacidade sobrevier por motivo de progressão ou agravamento dessa doença ou lesão".

353“Não será devido auxílio-doença ao segurado que se filiar ao Regime Geral de Previdência Social já portador da doença ou da lesão invocada como causa para o benefício, salvo quando a incapacidade sobrevier por motivo de progressão ou agravamento dessa doença ou lesão".

${ }^{354}$ Observação que não passou despercebida a Miguel Horvath Júnior: "Doença preexistente - A vedação da cobertura previdenciária ao segurado que ingressa no sistema já incapacitado para o trabalho revela a Previdência Social como executora de técnicas de seguro social. O sistema previdenciário existe para dar cobertura ao segurado e dependentes quando da ocorrência de um dos riscos ou contingências sociais protegidas que os impeça de obter sua subsistência através de seu trabalho, desde que eles ocorram após o ingresso no sistema. Não podemos esquecer o caráter contributivo do sistema. A lei veda a proteção previdenciária ao segurado que ingressa no sistema já incapacitado, porém lhe concede proteção nos casos da existência da doença ou lesão preexistente à filiação, desde que a incapacidade tenha sobrevindo por motivo de progressão ou agravamento dessa doença, como, v.g., no caso de segurado já hipertenso que se filiou à previdência social, mas que, no entanto, ainda estava apto para o trabalho. Isso porque a hipertensão é doença progressiva que, com o tempo, pode levar à incapacidade laboral". HORVATH JÚNIOR, Miguel. op. cit., p. 264.
} 


\subsection{Análise comparativa dos benefícios por incapacidade}

Em razão da contingência comum deflagradora, os três benefícios previdenciários por incapacidade laboral (aposentadoria por invalidez, auxílio-doença e auxílio-acidente) possuem como requisito essencial exatamente a constatação da incapacidade laboral, variando apenas em grau e intensidade em cada caso $^{355}$.

\subsubsection{Esclarecimento introdutório}

Antes de entrar propriamente na análise comparativa dos requisitos exigidos para a percepção de cada um dos três benefícios por incapacidade previstos em lei, é de se esclarecer como devem ser interpretados os eventos doença e invalidez arrolados pelo constituinte como aptos, desde que geradores de incapacidade laboral, a gerar o direito à percepção da prestação previdenciária.

A Lei n. 8.213/91 não traz qualquer conceito legal, porém a doutrina pátria converge no sentido de englobar tais eventos nas noções de doença e acidente geradores de incapacidade laboral.

Deve-se entender por doença a ocorrência de um evento interno ao corpo humano, não abrupto, que se desencadeia ao longo do tempo e que gera incapacidade laboral não de forma imediata, mas, protraída no tempo, em decorrência de sua evolução, progressão ou soma a outros males de mesma natureza.

Já o conceito de acidente faz referência a eventos abruptos, externos ao corpo humano, geradores de uma incapacidade laboral imediata ou que surge em curto espaço de tempo ${ }^{356}$.

$\mathrm{O}$ que se deve ter em mente é que o elemento relevante juridicamente para efeitos do reconhecimento (ou não) da existência do direito à percepção de prestação estatal nesta seara é a incapacidade laboral ${ }^{357}$, sendo irrelevante sua causa (doença ou lesão).

\footnotetext{
355“A perda definitiva da capacidade laboral é uma contingência social deflagradora da aposentadoria por invalidez. Distingue-se do auxílio-doença, também concebido para proteger o obreiro da incapacidade laboral, em razão de o risco social apresentar-se aqui com tonalidades mais intensas e sombrias, vale, dizer, em princípio, o quadro é irreversível". ROCHA, Daniel Machado da; BALTAZAR JÚNIOR, José Paulo. op. cit., p. 203-204.

"Na realidade, nosso sistema de seguridade social contempla dois tipos de contingências protegidas assim resumíveis: incapacidade laboral transitória e invalidez. Sem embargo, como será demonstrado, as diferenças entre ambas não são tão substanciais, senão meramente epidérmicas ou acidentais, mais como situações de necessidade de uma mesma contingência protegida do que contingências distintas." ALMANSA PASTOR, Jose Manuel. op. cit., p. 401 (tradução do original, em espanhol).

${ }^{356}$ Para maior aprofundamento acerca do assunto, confira-se: CUTAIT NETO, Michel. op. cit., p. 123-130.

${ }^{357}$ Interessante conceito de incapacidade é trazido por ALMANSA PASTOR, Jose Manuel. op. cit., p. 404 (tradução do original, em espanhol): "Como contingência protegida, a incapacidade laboral constitui uma
} 


\title{
8.3.2. Comparação propriamente dita
}

Para demonstrar a identidade de requisitos necessários à concessão das três prestações estatais decorrentes da incapacidade laboral (aposentadoria por invalidez, auxílio-doença e auxílio-acidente), passo a transcrever os três artigos relacionados da Lei n. $8.213 / 91$ :

\begin{abstract}
APOSENTADORIA POR INVALIDEZ
Art. 42. A aposentadoria por invalidez, uma vez cumprida, quando for o caso, a carência exigida, será devida ao segurado que, estando ou não em gozo de auxílio-doença, for considerado incapaz e insusceptível de reabilitação para o exercício de atividade que lhe garanta a subsistência, e ser-lhe-á paga enquanto permanecer nesta condição.
\end{abstract}

\section{AUXÍLIO-DOENÇA}

Art. 59. O auxílio-doença será devido ao segurado que, havendo cumprido, quando for o caso, o período de carência exigido nesta Lei, ficar incapacitado para o seu trabalho ou para a sua atividade habitual por mais de 15 (quinze) dias consecutivos.

\section{AUXíLIO-ACIDENTE}

Art. 86. O auxílio-acidente será concedido, como indenização, ao segurado quando, após consolidação das lesões decorrentes de acidente de qualquer natureza, resultarem sequelas que impliquem redução da capacidade para o trabalho que habitualmente exercia. (Redação dada pela Lei nº 9.528, de 1997)

Fácil perceber que, nos três casos, há identidade nos requisitos exigidos para a concessão: i) presença de incapacidade laboral; ii) qualidade de segurado; iii) carência (dispensada em se tratando de auxílio-acidente e, nos outros dois casos, nas hipóteses do art. 151, da Lei n. 8.213/91).

Decorrência inexorável de tal identidade é o reconhecimento da existência de um regime jurídico único, disciplinador de tais prestações de forma sistemática.

\footnotetext{
das causas primárias de necessidade social, consistente na incapacidade de ganhar por defeito de ingressos devido à incapacidade patológica e superveniente de trabalhar".

Também Miguel Horvath Júnior traz esclarecedor conceito de "incapacidade laboral": "Hodiernamente temos dois critérios que são adotados na legislação dos mais diversos países: Critério profissional: a incapacidade laborativa é avaliada em relação à diminuição que o segurado sofreu levando-se em conta única e exclusivamente a atividade que anteriormente exercia. Critério da possibilidade de ganhar a vida: a incapacidade de ganhar a vida também é denominada de incapacidade geral de trabalho. A incapacidade de trabalho para o trabalho em geral. A capacidade laboral residual deve ser avaliada não em relação à atividade anteriormente exercida mas em relação às possibilidades de desenvolvimento de outra atividade que lhe garanta a subsistência. A invalidez previdenciária, segundo nosso ordenamento (art. 42 da Lei $\mathrm{n}^{\circ}$ $8.213 / 91$ ), adota o critério da possibilidade de ganhar a vida, isto é, a incapacidade não é avaliada somente em relação à atividade anteriormente exercida pelo segurado mas sim em relação a qualquer outra atividade que lhe possa garantir a subsistência." HORVATH JÚNIOR, Miguel. op. cit., p. 260-261.
} 
Não abordarei no presente estudo os requisitos da qualidade de $\operatorname{segurado}^{358}$ e da carência $^{359}$, concentrando minha análise no requisito da incapacidade laboral, como uma das contingências sociais deflagradoras do direito humano fundamental à previdência social e elemento responsável pelo reconhecimento da existência de um regime jurídico único entre os três benefícios supramencionados.

Nesse diapasão, é certo que a contingência social da incapacidade laboral pode se manifestar no mundo fenomênico de formas variadas, de acordo com dois critérios relevantes: i) grau de extensão; ii) tempo de duração.

Em assim sendo, pode-se evoluir, de acordo com o critério do grau de extensão, da constatação de uma condição fática geradora de pequena redução de capacidade laboral, até a constatação de uma situação de incapacidade laboral para toda e qualquer atividade.

E, de acordo com o critério do tempo de duração, partir da constatação de uma incapacidade de curta duração (poucas horas ou dias), até a constatação de uma incapacidade laboral irreversível.

Como o direito humano fundamental à previdência social busca a proteção dos trabalhadores em face de eventos dificultadores ou inviabilizadores da percepção de remuneração pelo labor, tais devem ser os elementos balizadores da interpretação do grau de incapacidade laboral exigido para a configuração do direito humano fundamental a uma prestação estatal inserida na previdência social.

Ou seja, eventos que não gerem qualquer repercussão sobre a capacidade laboral do trabalhador, em nada alterando sua capacidade de obtenção de remuneração, ou cuja duração seja ínfima, não estão abarcados pelo direito humano fundamental à previdência social.

Ao contrário, eventos geradores de perda de capacidade laboral, mesmo que de forma apenas parcial, de molde a diminuir sua capacidade laboral, bem como aqueles geradores da necessidade de afastamento do trabalhador de seu labor, mesmo que por

\footnotetext{
${ }^{358} \mathrm{~A}$ qualidade de segurado diz respeito à qualidade de integrante, de beneficiário do regime geral de previdência social por parte do trabalhador, a depender de sua inscrição (art. 17, da Lei n. 8.213/91). Os segurados obrigatórios são arrolados no artigo 11, da Lei n. 8.213/91, sendo que o artigo 15 fixa hipóteses de manutenção da qualidade de segurado por certo período de tempo mesmo após o término das contribuições previdenciárias obrigatórias (chamado "período de graça").

359 “Período de carência é o número mínimo de contribuições mensais indispensáveis para que o beneficiário faça jus ao benefício, consideradas a partir do transcurso do primeiro dia dos meses de suas competências" (art. 24, caput, da Lei n. 8.213/91). Encontram-se fixadas no art. 25, da Lei n. 8.213/91, variando de acordo com cada benefício previsto em lei.
} 
poucos dias, devem ser abarcados como hábeis a gerar o direito à prestação estatal por incapacidade laboral.

Foi o que o legislador pátrio fez na disciplina legal dos três benefícios previdenciários por incapacidade, os quais abarcam todas as hipóteses a demandar proteção estatal.

No caso do benefício previdenciário de aposentadoria por invalidez, exige-se, por lei, o requisito ser "incapaz e insusceptível de reabilitação para o exercício de atividade que lhe garanta a subsistência".

Ou seja, deve-se comprovar a existência de uma incapacidade: i) quanto ao grau de extensão: para toda e qualquer atividade laboral que lhe garanta a subsistência ${ }^{360}$, e não apenas no tocante à atividade habitual do segurado; ii) quanto ao tempo de duração: sem prognóstico possível, inclusive, sem possibilidade de reabilitação para outra atividade laboral que the garanta a subsistência, não se exigindo, porém, que seja a mesma irreversível ${ }^{361}$.

Não se exige uma incapacidade laboral absoluta, ou seja, que inviabilize o segurado de exercer qualquer outra atividade laboral, mas sim uma incapacidade que lhe impeça de exercer outra atividade laboral que lhe garanta o mesmo nível remuneratório ou nível próximo.

Logo, caso o segurado consiga exercer outra atividade remunerada, porém, com nível de remuneração muito inferior, é de se entender como preenchido o requisito da incapacidade laboral para a percepção da aposentadoria por invalidez. Fala-se que o segurado, neste caso, manteve uma capacidade laboral apenas residual.

Agora, se o segurado estiver incapacitado para sua atividade laboral habitual, porém, puder desenvolver outra atividade laboral de nível próximo de remuneração, então,

\footnotetext{
360،Expressão digna de nota é que a incapacidade geradora da aposentadoria por invalidez há de impedir o exercício de atividade que lhe garanta a subsistência. Não se deve entender o evento gerador da aposentadoria por invalidez a incapacidade absoluta, total e completa do segurado. O sistema não exige o estado vegetativo laboral para a concessão deste benefício. (...) Ora, se a lei não exige, como vimos, incapacidade absoluta e total, é possível que ele possa exercitar a capacidade residual, de forma a obter uma complementação ao seu sustento". HORVATH JÚNIOR, Miguel. op. cit., p. 262-263.

361“A incapacidade permanente, por sua vez, deve ser entendida como aquela que não tem prognóstico de recuperação dentro de um prazo determinado, que não é possível prever, com precisão, a sua recuperação. Nada impede, contudo, que, futuramente, o segurado, em razão da evolução da medicina ou de fatores outros, venha a recuperar a capacidade laborativa. Essa é a razão pela qual a Lei fala que a aposentadoria por invalidez será paga enquanto o segurado estiver incapaz para o trabalho, denunciando a característica da provisoriedade desse benefício". DIAS, Eduardo Rocha; MACÊDO, José Leandro Monteiro de. op. cit., p. 218.
} 
não se encontra preenchido o requisito legal para efeitos de concessão da aposentadoria por invalidez $z^{362}$.

Também não se exige, conforme afirmado acima, uma incapacidade irreversível para o labor, mas a ausência de prognóstico favorável em termos de recuperação da capacidade laboral, não sendo possível, ademais, a reabilitação do segurado para o desempenho de outra atividade laboral que lhe garanta o mesmo nível de subsistência.

Por ser o benefício previdenciário por incapacidade que garante a maior prestação estatal (100\% sobre o salário de benefício calculado; art. 44, da Lei n. 8.213/91), a aposentadoria por invalidez é o benefício que exige o maior grau de extensão e tempo de duração da incapacidade laboral dentre os três.

Já o auxílio-doença se encontra em um grau intermediário entre a aposentadoria por invalidez e o auxílio-acidente, pois exige-se, por lei, que o segurado fique "incapacitado para o seu trabalho ou para a sua atividade habitual por mais de 15 (quinze) dias consecutivos".

Ou seja, deve-se comprovar a existência de uma incapacidade: i) quanto ao grau de extensão: apenas para a atividade habitual do segurado; ii) quanto ao tempo de duração: mais de quinze dias consecutivos, porém, com prognóstico favorável de recuperação da capacidade laboral em prazo previsível.

Flagrante o grau menor de exigência para a concessão do benefício previdenciário de auxílio-doença se comparado à aposentadoria por invalidez: a incapacidade laboral somente abarca a atividade habitual do segurado e o tempo de sua duração é menor, inclusive, com termo final previsível.

Também é compreendida pelo direito à percepção do auxílio-doença a hipótese de constatação de uma incapacidade laboral sem prognóstico de recuperação, porém, cujo grau de extensão é menor, a afetar unicamente a atividade habitual do segurado, possibilitando sua reabilitação para outra atividade profissional, caso em que o benefício é

\footnotetext{
${ }^{362}$ Confira-se, a propósito, relevante escólio sobre o tema: "A contingência social que dá direito à concessão da aposentadoria por invalidez é a incapacidade substancial e permanente para o trabalho. Substancial no sentido de que o segurado está incapaz de exercer atividade que lhe garanta a subsistência. Como a subsistência, na previdência social, pressupõe a manutenção limitada do nível de vida do beneficiário, essa incapacidade é para exercer atividade que lhe garanta, aproximadamente, o mesmo nível de subsistência que tinha antes da ocorrência da contingência social. Neste sentido, não é correto afirmar que a incapacidade que dá direito à aposentadoria por invalidez é necessariamente total. Se o segurado é capaz de exercer somente atividades que não lhe garantam, em termos aproximados, o mesmo nível de subsistência que tinha antes de se tornar incapaz, o benefício deve ser concedido". DIAS, Eduardo Rocha; MACÊDO, José Leandro Monteiro de. op. cit., p. 217.
} 
devido até a conclusão do processo de reabilitação profissional (art. 62, da Lei n. $8.213 / 91)$.

A solução legal é acertada, pois não obstante a hipótese aventada se enquadre no requisito da aposentadoria por invalidez no tocante ao tempo de duração da incapacidade laboral, seu enquadramento quanto ao grau de extensão da incapacidade é inegável dentro do benefício de auxílio-doença, pois se trata de uma incapacidade laboral de extensão muito menor do que aquela exigida para a concessão da aposentadoria por invalidez (para toda e qualquer atividade laboral que garanta a subsistência do segurado).

Tal solução evidencia que, não obstante o requisito da incapacidade laboral se desdobre nos dois critérios de aferição (grau de extensão e tempo de duração), no caso de conflito aparente entre eles, há de prevalecer o critério do grau de extensão da incapacidade, para efeitos de enquadramento da situação fática no benefício previdenciário legalmente previsto.

Seu grau intermediário em termos de rigor na exigência dos critérios do grau de extensão e tempo de duração da incapacidade laboral comparativamente aos benefícios de aposentadoria por invalidez e auxílio-acidente se reflete no valor do benefício a ser pago, qual seja, de 91\% sobre o salário de benefício calculado (art. 61, da Lei n. 8.213/91).

Por fim, há a previsão do benefício previdenciário por incapacidade do auxílioacidente, de menor grau de exigência no tocante ao nível de extensão da incapacidade laboral, já que, por lei, exige-se que, "após consolidação das lesões decorrentes de acidente de qualquer natureza, resultarem sequelas que impliquem redução da capacidade para o trabalho que habitualmente exercia".

Neste último caso, deve-se comprovar a existência de uma incapacidade: i) quanto ao grau de extensão: mera redução da capacidade para o trabalho habitual; ii) quanto ao tempo de duração: caráter permanente, tendente à irreversibilidade, pois o fato gerador que assegura o direito ao benefício decorre da consolidação das lesões redutoras da capacidade laboral.

Trata-se, portanto, de um grau de exigência muito mais mitigado, se comparado com o grau de extensão de incapacidade laboral exigido para os outros dois benefícios previdenciários por incapacidade, uma vez que, no caso do auxílio-acidente, o que se exige é apenas a redução da capacidade laboral para a atividade habitual, e não sua supressão, 
seja para a atividade habitual (caso do auxílio-doença), seja para toda e qualquer atividade que lhe garanta a subsistência (caso da aposentadoria por invalidez).

Por consequência, também é o benefício por incapacidade de menor valor, qual seja, de apenas $50 \%$ sobre o salário de benefício calculado (art. $86, \S 1^{\circ}$, da Lei $n$. $8.213 / 91)$.

O quadro a seguir bem evidencia os diferentes níveis exigíveis de extensão de incapacidade laboral para cada benefício por incapacidade, bem como seu tempo de duração:

\begin{tabular}{|l|l|l|}
\hline & $\begin{array}{l}\text { Grau de extensão da } \\
\text { incapacidade }\end{array}$ & $\begin{array}{l}\text { Tempo de duração da } \\
\text { incapacidade }\end{array}$ \\
\hline Aposentadoria por invalidez & $\begin{array}{l}\text { Incapaz para toda e qualquer } \\
\text { atividade que lhe garanta a } \\
\text { subsistência }\end{array}$ & $\begin{array}{l}\text { Sem prognóstico favorável de } \\
\text { recuperação }\end{array}$ \\
\hline Auxílio-doença & $\begin{array}{l}\text { Incapaz apenas para sua } \\
\text { atividade habitual }\end{array}$ & $\begin{array}{l}\text { Temporária, com prognóstico } \\
\text { favorável de recuperação }\end{array}$ \\
\hline Auxílio-acidente & $\begin{array}{l}\text { Mera redução de capacidade } \\
\text { para sua atividade habitual }\end{array}$ & Tendente à irreversibilidade \\
\hline
\end{tabular}

\subsection{Conclusões}

Duas conclusões nodais e importantíssimas podem ser extraídas da análise comparativa realizada.

1. É incompleta a simplificação levada a efeito por boa parte da doutrina previdenciária pátria no sentido de separar os três benefícios por incapacidade no seguinte formato: i) aposentadoria por invalidez = incapacidade total e permanente; ii) auxíliodoença $=$ incapacidade total e temporária; iii) auxílio-acidente $=$ incapacidade parcial e permanente ${ }^{363}$.

Isso porque, da leitura dos artigos disciplinadores de cada benefício previdenciário por incapacidade, bem como da análise comparativa realizada acima, verifica-se que o grau

\footnotetext{
${ }^{363}$ É a posição, exemplificativamente, dos seguintes e autorizados autores: i) CUTAIT NETO, Michel. op. cit., p. 118-122; ii) ROCHA, Daniel Machado da; BALTAZAR JÚNIOR, José Paulo. op. cit., p. 204; iii) HORVATH JÚNIOR, Miguel. op. cit., p. 263, 311 e 336; iv) SANTOS, Marisa Ferreira dos. Direito previdenciário esquematizado. 3. ed. São Paulo: Saraiva, 2013. p. 300-301; v) AMADO, Frederico. Curso de direito e processo previdenciário. 6. ed. Salvador: JusPODIVM, 2015. p. 547, 681 e 714.
} 
de extensão da incapacidade laboral varia em cada benefício por incapacidade, numa escala de três níveis (e não de apenas dois, como consta da classificação ora questionada).

Apenas no tocante ao tempo de duração da incapacidade laboral é que a escala realmente atingiria apenas dois níveis (sem prognóstico favorável = tendente à irreversibilidade e com prognóstico favorável = duração temporária), mas, mesmo nesse caso, há diferenças relevantes no tempo de duração da incapacidade laboral, se comparados os requisitos da aposentadoria por invalidez e do auxílio-acidente: este exige um grau mais elevado de duração da incapacidade, se comparado com aquele, pois exige a consolidação das lesões incapacitantes, e não apenas a ausência de um prognóstico favorável em termos de recuperação da capacidade laboral plena.

Não é sem razão que o artigo $86, \S 1^{\circ}$, da Lei n. 8.213/91, em sua parte final garante o pagamento do benefício de auxílio-acidente "até a véspera do início de qualquer aposentadoria ou até a data do óbito do segurado". Tal disposição legal reflete o caráter vitalício do benefício, de acordo com o exigido caráter irreversível da redução da capacidade laboral.

De qualquer sorte, reputo inviável simplificar o critério do tempo de duração da incapacidade laboral para o binômio temporário/permanente, pois não reflete o nível de exigência contido em cada benefício por incapacidade.

Por levar a equívocos, deve ser afastada tal simplificação, inútil em termos científicos.

De acordo com o sistema constitucional de proteção previdenciária da contingência social da incapacidade laboral decorrente de doença ou invalidez, bem como da análise sistemática das disposições disciplinadoras do regime previdenciário brasileiro, além das regras constantes da Lei n. 8.213/91, sugiro a seguinte simplificação, para efeitos didáticos: i) aposentadoria por invalidez = incapacidade laboral para toda e qualquer atividade que garanta o sustento do segurado, sem prognóstico favorável de recuperação; ii) auxíliodoença = incapacidade laboral unicamente para a atividade habitual do segurado, de caráter temporário, com prognóstico favorável de recuperação ou reabilitação para outra atividade profissional; iii) auxílio-acidente = redução da capacidade laboral para a atividade habitual do segurado, tendente à irreversibilidade.

2. É equivocado excluir o benefício previdenciário do auxílio-acidente do rol dos benefícios previdenciários por incapacidade laboral, uma vez que a contingência social 
protegida e os requisitos legais para a concessão são os mesmos, variando unicamente em grau de extensão e tempo de duração da incapacidade laboral exigidos.

Em assim sendo, é de se inserir o auxílio-acidente dentro do regime jurídico único disciplinador dos benefícios previdenciários por incapacidade laboral.

Decorrência lógica e inescapável de tal conclusão é o fato de o caráter indenizatório, não substitutivo da remuneração, de que se reveste o auxílio-acidente ${ }^{364}$, ser meramente lateral, ancilar, não sendo capaz de excluí-lo do rol dos benefícios por incapacidade.

Evidente, pois é o grau de extensão da incapacidade laboral exigido para a percepção do benefício que faz com que o mesmo seja classificado como substitutivo da remuneração ou não, e não o contrário. A interpretação deve partir, à evidência, da contingência social protegida, e não do valor do benefício.

$\mathrm{Na}$ verdade, trata-se de mais uma classificação possível de tais benefícios, que não possui, porém o condão de contrapô-los de molde a excluir qualquer deles do regime jurídico protetivo comum dos benefícios decorrentes da incapacidade laboral.

No próximo capítulo tratarei especificamente do auxílio-acidente, aprofundando as razões pelas quais o mesmo deve integrar o rol dos benefícios previdenciários por incapacidade laboral, sofrendo, assim, o influxo do regime jurídico protetivo único na interpretação e aplicação de suas regras.

\footnotetext{
${ }^{364} \mathrm{Já}$ os benefícios previdenciários de aposentadoria por invalidez e auxílio-doença, por exigirem o grau pleno de incapacidade laboral, devem ser substitutivos da remuneração, e não indenizatórios, assegurandose a máxima proteção possível.
} 


\section{DA INCLUSÃO DO AUXÍLIO-ACIDENTE NO ROL DOS BENEFÍCIOS PREVIDENCIÁRIOS PAGOS EM RAZÃo DA CONSTATAÇÃO DA CONTINGÊNCIA SOCIAL DA INCAPACIDADE LABORAL}

\subsection{Razões fundantes}

Procurei deixar claro já no capítulo anterior minha conclusão no sentido de que são três (e não dois) os benefícios previdenciários previstos para proteção da contingência social da incapacidade laboral decorrente de doença ou invalidez, a saber: i) aposentadoria por invalidez; ii) auxílio-doença; iii) auxílio-acidente.

Tal conclusão é sacada, de forma inexorável, a partir de uma visão pós-positivista do direito à previdência social, entendido este como direito humano fundamental de segunda dimensão, dentro de um enfoque dos direitos humanos fundamentais como fruto de um processo de lutas pelo reconhecimento da pessoa humana como sujeito de direitos, bem como do processo de sacralização da pessoa humana.

Dentro deste enfoque, a chave interpretativa de maior importância a reger tais direitos é voltada à garantia de sua efetividade, em um processo tendente à universalização da proteção jurídico-estatal.

Logo, dentre as diversas classificações possíveis das prestações estatais previstas, há que se adotar aquela que traga maior efetividade, além de corresponder aos anseios do legislador constituinte. Somente assim se adotará a classificação mais útil em termos científicos.

No caso em tela, inegavelmente, a classificação mais útil é aquela que parte das contingências sociais arroladas pelo constituinte como aptas a gerar o direito a cada prestação previdenciária.

Em outras palavras, em se tratando do direito humano fundamental à previdência social, a classificação mais importante, mais útil e mais eficaz é aquela que adota como elemento de discrímen as contingências sociais arroladas pelo constituinte como aptas a gerar a proteção social estatal. 
Tal deve ser a chave de leitura adotada para efeitos de classificação das prestações previdenciárias previstas em lei, a permitir, inclusive, e conforme já demonstrado, a aglutinação de mais de uma prestação dentro de um mesmo regime jurídico protetivo.

Partindo, assim, da contingência social da incapacidade laboral decorrente de doença ou invalidez, arrolada pelo constituinte pátrio no artigo 201, I, da Constituição, chega-se, inegavelmente, aos três benefícios mencionados no primeiro parágrafo: aposentadoria por invalidez, auxílio-doença e auxílio-acidente.

Como consequência, devem os três ser estudados, interpretados e compreendidos de forma integrada, sistemática, o que significa dizer que as disposições legais disciplinadoras de cada qual também devem ser interpretadas, compreendidas e aplicadas de forma sistemática e teleológica, tendo como baliza exatamente o fato de se tratar de benefícios protetivos da incapacidade laboral.

Sucede que a doutrina pátria, em sua esmagadora maioria, ao buscar conceituar o benefício previdenciário do auxílio-acidente, o faz reiteradamente ressaltando seu caráter indenizatório $^{365}$, o que o coloca em contraposição aos outros dois benefícios previdenciários por incapacidade previstos em lei $\mathrm{i}^{366}$.

Também são reiterados os entendimentos exarados pelos nossos Tribunais pátrios no sentido de considerar o auxílio-acidente como benefício desvinculado daqueles protetivos da contingência social da incapacidade laboral, em razão de seu caráter indenizatório, logo, indeferindo sua concessão mesmo quando preenchidos os seus requisitos mediante prova técnica produzida ao longo da instrução processual, sendo exemplos as seguintes ementas de julgados proferidos em sede do Tribunal Regional Federal da Terceira Região:

PREVIDENCIÁRIO. AGRAVO LEGAL. APOSENTADORIA POR INVALIDEZ. NÃO PREENCHIDOS OS REQUISITOS LEGAIS. DECISÃO FUNDAMENTADA.

\footnotetext{
${ }^{365}$ Prova de tal enfoque é dada na seguinte passagem: “O auxílio-acidente é um benefício previdenciário pago mensalmente ao segurado acidentado como forma de indenização, sem caráter substitutivo do salário, pois é recebido cumulativamente com o mesmo, quando, após a consolidação das lesões decorrentes de acidente de qualquer natureza - e não somente de acidentes de trabalho -, resultarem sequelas que impliquem redução da capacidade para o trabalho que habitualmente exercia - Lei n. 8.213/91, art. 86, caput”. CASTRO, Carlos Alberto Pereira de; LAZZARI, João Batista. op. cit., p. 797.

${ }^{366}$ Outras definições dadas por doutrina pátria abalizada para o benefício previdenciário de auxílio-acidente, a ressaltar seu caráter indenizatório em detrimento da contingência social protegida, são encontradas em: i) IBRAHIM, Fábio Zambitte. op. cit., p. 648; ii) HORVATH JÚNIOR, Miguel. op. cit., p. 335; iii) MARTINEZ, Wladimir Novaes. Auxílio-acidente. São Paulo: LTr, 2006. p. 23-25; iv) DIAS, Eduardo Rocha; MACÊDO, José Leandro Monteiro de. op. cit., p. 227; v) AMADO, Frederico. op. cit., p. 701.
} 
I - Não procede a insurgência da parte agravante porque não preenchidos os requisitos legais para a concessão de aposentadoria por invalidez ou auxíliodoença.

(...)

V - Prejudicado o pleito de concessão de auxílio-acidente, por não constar da petição inicial, não sendo possível inovar o pedido, em sede de agravo legal.

(...)

IX - Agravo improvido.

(TRF $3^{\mathrm{a}}$ Região, $8^{\mathrm{a}}$ TURMA, AC 0005207-68.2008.4.03.6114, Rel. DESEMBARGADORA FEDERAL MARIANINA GALANTE, julgado em 05/12/2011, e-DJF3 Judicial 1 DATA:15/12/2011) (grifado)

PREVIDENCIÁRIO E PROCESSUAL CIVIL - SENTENÇA EXTRA PETITA E ARTIGO 515, $\S 1^{\circ}$ DO CPC - CONCESSÃO DE BENEFÍCIO - DECADÊNCIA - BENEFÍCIOS POR INCAPACIDADE - DATA DE INÍCIO - HONORÁRIOS ADVOCATÍCIOS.

1.O auxílio-acidente difere dos demais benefícios por incapacidade, pois sua finalidade é a compensação (indenização) pela perda da capacidade de trabalho. Por isso configura julgamento "extra petita" a sua concessão, se o segurado relata incapacidade total e permanente, com pedido de aposentadoria por invalidez, ou, subsidiariamente, o reconhecimento da incapacidade temporária e submissão a processo de reabilitação profissional, com pedido de auxílio-doença, pois nestas duas espécies de benefício o objetivo é a paralisação das atividades profissionais com substituição da renda mensal do obreiro.

(...)

9.Recurso e remessa oficial parcialmente providos.

(TRF $3^{\text {a }}$ Região, $9^{\text {a }}$ TURMA, AC 0037781-37.2005.4.03.9999, Rel. DESEMBARGADORA FEDERAL MARISA SANTOS, julgado em 26/6/2006, DJU DATA:14/9/2006) (grifado)

Não obstante os respeitáveis entendimentos, pelas razões já expostas, não posso com eles concordar.

Isso porque o caráter inegavelmente indenizatório do benefício previdenciário de auxílio-acidente decorre do fato de o mesmo não ser substitutivo da remuneração do trabalhador, diversamente da aposentadoria por invalidez e do auxílio-doença.

Porém, tal constatação leva em conta o critério de classificação do caráter substitutivo (ou não) do valor pago a título de benefício previdenciário, o qual não foi arrolado pelo legislador constituinte ou ordinário como elemento hábil a classificar as prestações previdenciárias estatais.

De se recordar, uma vez mais, que o legislador constituinte, de forma correta e louvável, adotou como elemento de discrímen o critério das contingências sociais 
protegidas, sendo que o legislador ordinário, por sua vez, adotou o critério - já questionável, diga-se de passagem - dos beneficiários.

A classificação que leva em conta o caráter substitutivo (ou não) da remuneração por parte dos benefícios previdenciários, não obstante seja possível, possui restrita utilidade prática, limitada, em termos de proteção, basicamente à garantia da percepção de um valor mínimo no caso de se tratar de benefício substitutivo da remuneração (art. 201, $\S 2^{\circ}$, da Constituição).

Ou seja, tal critério possui relevância jurídica, porém, muito limitada e restrita, jamais podendo, por isso mesmo, assumir o papel de elemento de classificação das prestações previdenciárias estatais.

Até se entendem as razões históricas da adoção de tal elemento como supostamente identificador da natureza jurídica ontológica do benefício previdenciário de auxílioacidente como indenizatório, pela constatação de uma redução da capacidade laboral do trabalhador. Afinal de contas, suas raízes históricas puseram ênfase exatamente no caráter indenizatório da redução da capacidade laboral comparativamente com os demais trabalhadores, indenizando o trabalhador que deixou de possuir a mesma capacidade de trabalho comparativamente aos demais trabalhadores ${ }^{367}$.

Porém, com o advento da Constituição de 1988 e a consolidação da previdência social em um regime jurídico único, qual seja, a seguridade social, não cabe mais tal conceituação, posto que embasada em critério defasado, não adotado pelo constituinte e que não reflete o caráter altamente protetivo e efetivo do regime jurídico atinente aos direitos humanos fundamentais.

Logo, a conceituação do benefício previdenciário de auxílio-acidente não pode mais partir de seu caráter indenizatório, cuja importância atual somente serve para diferenciá-lo dos dois outros benefícios por incapacidade, em termos de proteção e garantia de um valor mínimo a ser pago a título de benefício: garantia de um salário mínimo para os casos de aposentadoria por invalidez e auxílio-doença, o que não é assegurado ao auxílioacidente.

\footnotetext{
367“'O dealbar mais antigo do auxílio-acidente é o art. 18 do Decreto-lei n. 9.036/44 (regulamentado pelo Decreto n. 18.809/45), quando aquela Lei de Acidentes do Trabalho disciplinou a incapacidade parcial e permanente do obreiro, mediante uma prestação inominada, equivalente de três a oitenta centésimos da quantidade correspondente a quatro anos de diárias, a esse tempo com a configuração de indenização de um prejuízo causado à aptidão de trabalho do segurado". MARTINEZ, Wladimir Novaes. Auxílio-acidente, cit., p. 15.
} 
Para efeitos de conceituação, há que se partir da contingência social protegida (incapacidade laboral decorrente de doença ou invalidez), bem como do regime jurídico unificador dos benefícios por incapacidade.

Assim é que, na atual quadra, o benefício de auxílio-acidente deve ser conceituado como direito humano fundamental previdenciário à percepção de uma prestação estatal decorrente da constatação de sequelas causadoras de redução da capacidade laboral para a atividade habitual.

Em razão do exposto, concordo plenamente com as seguintes observações doutrinárias:

O auxílio-acidente é benefício previdenciário que protege as sequelas resultantes de acidente de qualquer natureza que reduza a capacidade para o trabalho que o segurado habitualmente exercia. Assim, o que se protege não é o acidente em si, e sim a consequência deste acidente, a redução da capacidade para o trabalho do segurado, pois é esta redução que vai gerar a necessidade social que deve ser protegida pela previdência social por meio do benefício em comento $^{368}$.

Lembrando uma vez mais: é decorrência inexorável da análise das prestações previdenciárias a partir das contingências sociais protegidas o reconhecimento da existência de três benefícios previdenciários protetores da incapacidade laboral decorrente de doença ou invalidez, cujos requisitos para a concessão variam unicamente em razão do grau de extensão e tempo de duração de tal incapacidade: i) aposentadoria por invalidez = incapacidade para toda e qualquer atividade laboral, sem prognóstico favorável de recuperação; ii) auxílio-doença = incapacidade total para a atividade habitual, com prognóstico favorável de recuperação em prazo previsível ou possibilidade de reabilitação para outra atividade profissional; iii) auxílio-acidente = redução da capacidade laboral para a atividade habitual, com tendência de irreversibilidade (após consolidação das lesões).

\subsection{Conclusões}

Tal enfoque, constitucional, com ênfase na proteção e efetividade do direito à previdência social como direito humano fundamental social, traz consequências jurídicas de enorme relevo em termos de proteção do direito à percepção do auxílio-acidente, inclusive com maior abrangência de seu conteúdo e alcance, a saber:

\footnotetext{
${ }^{368}$ FARIAS, Luciana Moraes de. Auxílio-acidente. São Paulo: LTr, 2012. p. 52.
} 
1. Por se tratar de benefício previdenciário também voltado à proteção da contingência social da incapacidade laboral, seu rol de beneficiários deve ser o mesmo dos benefícios de aposentadoria por invalidez e auxílio-doença, não havendo qualquer elemento constitucional de discrímen que justifique uma menor proteção em termos de beneficiários.

Por decorrência, não há outra solução jurídica possível que não reputar inconstitucional o prescrito pelo artigo $18, \$ 1^{\circ}$, da Lei $n$. 8.213/91, a saber: "somente poderão beneficiar-se do auxílio-acidente os segurados incluídos nos incisos I, VI e VII do artigo 11 desta Lei”.

Por lei, são beneficiários do auxílio-acidente unicamente as seguintes categorias de segurados: empregados (inciso I), trabalhadores avulsos (inciso VI) e segurados especiais (inciso VII). Estão excluídos da proteção, por consequência, os demais trabalhadores: empregados domésticos (inciso II), contribuintes individuais (inciso V) e facultativos (art. 13).

Sucede que, conforme já afirmado, a contingência social protegida pelo auxílioacidente é idêntica àquela protegida pela aposentadoria por invalidez e auxílio-doença: incapacidade laboral decorrente dos eventos de doença ou invalidez.

Logo, não há justificativa plausível para a menor proteção em termos de beneficiários acobertados pelo auxílio-acidente. Todos os trabalhadores contribuintes do regime geral de previdência social devem ser agraciados com o auxílio-acidente previdenciário, desde que constatada a existência de redução de sua capacidade laboral para a atividade habitual.

$\mathrm{Na}$ verdade, a restrição legal dos beneficiários do auxílio-acidente também possui raízes históricas $^{369}$, já que, até as alterações trazidas pelo advento da Lei n. 9.032/95, havia a previsão legal unicamente do auxílio-acidente de natureza acidentária, ou seja, decorrente de acidente do trabalho (arts. 19 a 21, da Lei n. 8.213/91) (370. $^{370}$

\footnotetext{
369“، A limitação deste benefício aos segurados empregados, avulsos e especiais é feita pelo art. 18 , $\S 1^{\circ}$, da Lei $\mathrm{n}^{\circ} 8.213 / 91$, apesar do art. 86 trazer previsão genérica. A restrição é oriunda da origem do benefício, o antigo auxílio-acidente ou auxílio-suplementar, previsto na Lei $\mathrm{n}^{\circ} 6.367 / 76$. À época, era benefício restrito à sequela produzida por acidente do trabalho, e daí a limitação aos segurados que são objeto de tutela do seguro de acidentes do trabalho. Atualmente, o auxílio-acidente não se limita mais a acidentes do trabalho". IBRAHIM, Fábio Zambitte. op. cit., p. 649.

${ }^{370} \mathrm{O}$ benefício de auxílio-acidente ainda padece de diversas abordagens equivocadas, posto que estanques, no tocante ao seu sentido e alcance, inclusive, no tocante ao termo inicial de advento de sua espécie previdenciária, prevalecendo, não obstante, o advento da lei n. 9.032/95 como marco temporal e legislativo,
} 
Porém, desde o advento da Constituição de 1988 já deveria ter ocorrido a modificação de compreensão acerca do grau de abrangência das prestações previdenciárias por incapacidade laboral, interpretando-se as disposições legais à luz do regime protetivo constitucional único, e não de forma literal.

De qualquer sorte, a Lei n. 9.032/95 adequou a lei ao regime jurídico constitucional, corrigindo grave distorção histórica, em prol dos trabalhadores.

A partir daí, não cabe mais a interpretação literal e isolada do prescrito pelo artigo 18, $\S 1^{\circ}$, da Lei n. 8.213/91, devendo ser estendido o rol de beneficiários do auxílioacidente para todos os segurados arrolados no artigo 11, da Lei n. 8.213/91, além do segurado facultativo (art. 13).

Não há que se falar em ofensa à exigência constitucional da prévia fonte de custeio (art. $195, \S 5^{\circ}$, da Constituição), pois não se está falando em criação de novo benefício previdenciário, mas, em evolução na interpretação do regime constitucional de proteção previdenciária, que desde o seu início assegura a todos os beneficiários do regime geral de previdência social a percepção do auxílio-acidente, desde que constatada a presença da contingência social protegida ${ }^{371}$.

2. A expressão legal “acidente de qualquer natureza" contida no artigo 86, da Lei n. $8.213 / 91$, deve ser compreendida levando-se em conta a contingência social protegida pela prestação estatal: a redução da capacidade laboral.

Disso resulta a irrelevância jurídica dos eventos deflagradores da redução da capacidade laboral para efeitos da concessão do auxílio-acidente, pois, conforme já demonstrado no capítulo 8, a doutrina pátria é praticamente uníssona ao interpretar os eventos da "doença" e "invalidez" previstos na constituição (art. 201, I, da Constituição) como correspondentes aos eventos da "doença" (internos ao corpo humano, protraídos no tempo) e do "acidente" (externos, de efeitos imediatos), logo, a abarcar ambos os fenômenos, e não apenas um deles.

a saber: i) ROCHA, Daniel Machado da; BALTAZAR JÚNIOR, José Paulo. op. cit., p. 321; ii) CASTRO, Carlos Alberto Pereira de; LAZZARI, João Batista. op. cit., p. 797; iii) FARIAS, Luciana Moraes de. op. cit., p. 56-58. Em sentido contrário, fixando o termo inicial do auxílio-acidente previdenciário apenas em 31.12.2008, quando do advento do Decreto n. 6.722/2008, confira-se: HORVATH JÚNIOR, Miguel. op. cit., p. 335-336.

${ }^{371}$ De acordo, assim, com a crítica feita a tal restrição, nos seguintes termos: "Considerando o fato de o benefício, na redação original, apenas ser devido nos casos em que caracterizado o acidente do trabalho, a restrição no âmbito subjetivo até poderia ser compreendida. Entretanto, a partir da extensão promovida para os acidentes de qualquer natureza, a limitação subjetiva torna-se difícil de ser justificada". ROCHA, Daniel Machado da; BALTAZAR JÚNIOR, José Paulo. op. cit., p. 317-318. 
Assim é que a concessão da aposentadoria por invalidez depende da constatação da incapacidade laboral para toda e qualquer atividade profissional decorrente de doença ou acidente, do mesmo modo que a concessão do auxílio-doença depende da constatação da incapacidade laboral para a atividade profissional habitual, também decorrente de qualquer dos eventos (doença ou acidente).

São afirmações pacíficas, sobre as quais não pairam divergências doutrinárias ou jurisprudenciais atualmente, válidas mesmo para o auxílio-doença, não obstante sua nomenclatura apenas faça menção a uma das duas espécies de eventos fenomênicos deflagradores da incapacidade laboral (doença).

Não há razões e justificativas plausíveis, pois, para limitar o espectro de alcance do auxílio-acidente para englobar unicamente os casos de redução da capacidade laboral deflagrados por acidentes, deixando de fora aqueles decorrentes de doenças.

Da mesma forma que na conclusão anterior, por se tratar de benefício protetivo da contingência social da incapacidade laboral, o auxílio-acidente deve seguir o mesmo regime jurídico dos dois outros benefícios por incapacidade previstos (aposentadoria por invalidez e auxílio-doença), não podendo ter seu alcance reduzido, sob pena de incidir em inconstitucionalidade.

O elemento relevante juridicamente para sua interpretação é a contingência da incapacidade laboral, e não a ocorrência de acidente ou doença.

Em assim sendo, não obstante o entendimento atual do Superior Tribunal de Justiça esteja correto em abarcar a doença profissional como fato hábil a gerar a proteção previdenciária pela via do auxílio-acidente, equivoca-se, data maxima venia, ao exigir nexo causal entre o evento incapacitante e o labor, conforme se verifica em ementa de julgado proferido em sede de recursos repetitivos:

RECURSO ESPECIAL REPETITIVO. ART. 105, III, ALÍNEA A DA CF. DIREITO PREVIDENCIÁRIO. AUXÍLIO-ACIDENTE. REQUISITOS: COMPROVAÇÃO DO NEXO DE CAUSALIDADE E DA REDUÇÃO PARCIAL DA CAPACIDADE DO SEGURADO PARA O TRABALHO. DESNECESSIDADE DE QUE A MOLÉSTIA INCAPACITANTE SEJA IRREVERSÍVEL. NÃO INCIDÊNCIA DA SÚMULA 7/STJ. PARECER MINISTERIAL PELO PROVIMENTO DO RECURSO ESPECIAL. RECURSO ESPECIAL PROVIDO.

1. Nos termos do art. 86 da Lei 8.213/91, para que seja concedido o auxílioacidente, necessário que o segurado empregado, exceto o doméstico, o trabalhador avulso e o segurado especial (art. 18, § 1o. da Lei 8.213/91), tenha redução permanente da sua capacidade laborativa em decorrência de acidente de qualquer natureza. 
2. Por sua vez, o art. 20, I da Lei 8.213/91 considera como acidente do trabalho a doença profissional, proveniente do exercício do trabalho peculiar à determinada atividade, enquadrando-se, nesse caso, as lesões decorrentes de esforços repetitivos.

3. Da leitura dos citados dispositivos legais que regem o benefício acidentário, constata-se que não há nenhuma ressalva quanto à necessidade de que a moléstia incapacitante seja irreversível para que o segurado faça jus ao auxílio-acidente.

4. Dessa forma, será devido o auxílio-acidente quando demonstrado o nexo de causalidade entre a redução de natureza permanente da capacidade laborativa e a atividade profissional desenvolvida, sendo irrelevante a possibilidade de reversibilidade da doença. Precedentes do STJ.

5. Estando devidamente comprovado na presente hipótese o nexo de causalidade entre a redução parcial da capacidade para o trabalho e o exercício de suas funções laborais habituais, não é cabível afastar a concessão do auxílio-acidente somente pela possibilidade de desaparecimento dos sintomas da patologia que acomete o segurado, em virtude de tratamento ambulatorial ou cirúrgico.

6. Essa constatação não traduz, de forma alguma, reexame do material fático, mas sim valoração do conjunto probatório produzido nos autos, o que afasta a incidência do enunciado da Súmula 7 desta Corte.

7. Recurso Especial provido.

(REsp 1.112.886/SP, Rel. Ministro NAPOLEÃO NUNES MAIA FILHO, $3^{\mathrm{a}}$ SEÇÃO, julgado em 25/11/2009, DJe 12/2/2010)

Tal entendimento, com todo o respeito, tolhe direito humano fundamental dos segurados, pois exige, sem supedâneo constitucional ou mesmo legal, a existência de nexo causal entre o evento redutor da incapacidade e o labor, elemento que não faz parte da contingência social protegida (a incapacidade laboral) ${ }^{372}$.

Defendo, assim, uma interpretação ampliativa da expressão legal "acidente de qualquer natureza", que deve ser lida de forma sistemática e teleológica como "redução, decorrente de qualquer evento, da capacidade laboral para a atividade habitual”.

Não obstante, é de se reconhecer que o entendimento doutrinário atualmente prevalente conclui em sentido oposto, qual seja, no sentido de que somente a redução da capacidade laboral levada a cabo por acidentes é que seriam hábeis a gerar a proteção previdenciária por meio do auxílio-acidente ${ }^{373}$, excluindo-se expressamente os eventos de doença.

\footnotetext{
372، $\mathrm{O}$ direito cria suas próprias realidades e dentro da estrutura do regime geral de previdência social mostrase mais adequado o alargamento da proteção social com a inclusão do benefício auxílio-acidente no rol dos benefícios previdenciários que tenham como causa, além dos acidentes de qualquer natureza, as doenças não relacionadas com o trabalho, e nas palavras de Wladimir Martinez: 'até porque ele pretende cobrir qualquer evento que diminua a capacidade para o trabalho habitual"'. FARIAS, Luciana Moraes de. op. cit., p. 61. Para maior aprofundamento, confiram-se páginas 58-64.

${ }^{373}$ Confira-se, dentre outros: i) ROCHA, Daniel Machado da; BALTAZAR JÚNIOR, José Paulo. op. cit..p. 315; ii) CASTRO, Carlos Alberto Pereira de; LAZZARI, João Batista. op. cit., p. 797; iii) IBRAHIM, Fábio Zambitte. op. cit., p. 648; iv) DIAS, Eduardo Rocha; MACÊDO, José Leandro Monteiro de. op. cit., p. 227.
} 
Espero ter apresentado novas luzes à questão, a possibilitar maiores reflexões e, futuramente, uma análise diferente para o problema, dentro de um viés mais efetivo e protetivo da pessoa humana. 


\section{IDENTIDADE ONTOLÓGICA ENTRE OS BENEFÍCIOS PREVIDENCIÁRIOS POR INCAPACIDADE E SEU COROLÁRIO: DA FUNGIBILIDADE MATERIAL ENTRE ELES}

\subsection{Introdução}

Ao se estudar o direito à previdência social dentro do enfoque dos direitos humanos fundamentais sociais, com os evidentes ganhos em termos de efetividade trazidos pela visão pós-positivista, mediante a prevalência da constituição como ápice do ordenamento jurídico estatal e norte interpretativo, obteve-se seu real sentido e alcance, com a percepção inolvidável de que seu estudo deve partir do elemento fundamental da contingência social.

Tal elemento, nuclear, permitiu o aglutinamento das prestações sociais estatais ao redor de cada contingência prevista constitucionalmente, sendo que, para efeitos do presente estudo, destacou-se aquela contingência social responsável pela junção de três benefícios previdenciários, qual seja, a incapacidade laboral decorrente de doença ou invalidez (art. 201, I, da Constituição).

Eis o porquê da utilização da expressão "benefícios por incapacidade" para se referir aos três: aposentadoria por invalidez, auxílio-doença e auxílio-acidente.

Sua junção, conforme demonstrado nos dois últimos capítulos (8 e 9), tem por razões os fatos de se prestarem à proteção da mesma contingência social (incapacidade laboral) e o de que seus requisitos legais são semelhantes, variando unicamente em relação ao grau de incapacidade laboral exigido para a concessão de cada qual, em termos de grau de extensão e tempo de duração: i) aposentadoria por invalidez = incapacidade para toda e qualquer atividade laboral que garanta o sustento, sem prognóstico de recuperação; ii) auxílio-doença $=$ incapacidade para a atividade laboral habitual, com prognóstico favorável de recuperação em intervalo de tempo previsível ou possibilidade de reabilitação para outra atividade profissional; iii) auxílio-acidente = redução da capacidade laboral para a atividade habitual, com tendência de irreversibilidade.

Ou seja, os três benefícios previdenciários, por protegerem a mesma contingência social e terem o mesmo regime jurídico em termos de requisitos legais, possuem, na verdade, uma identidade ontológica, a fundamentar a existência de um regime jurídico único, comum, a discipliná-los. 
Disso resulta, conforme já demonstrado, que a interpretação e aplicação das regras legais de disciplina de cada benefício previdenciário por incapacidade devem seguir os ditames constitucionais e o sistema jurídico comum de regência, não cabendo, nesta seara, a interpretação literal e individual de cada disposição legal, mas, ao contrário, mediante a utilização dos métodos hermenêuticos sistemático e teleológico.

Isso porque tal identidade ontológica traz, necessariamente, uma identidade em termos lógicos, que se reflete exatamente no necessário regime jurídico comum de regência dos três benefícios por incapacidade.

Veja que tal regime jurídico único não trata, portanto, de uma mera opção legislativa, mesmo que constitucional, mas, de uma exigência decorrente da identidade ontológica existente entre os três benefícios previdenciários por incapacidade.

Logo, não há margem para o legislador buscar separar ou tratar de forma estanque cada qual. Sua ligação é lógica, de substância e por decorrência exige uma identidade de tratamento jurídico, sob pena de violação do próprio direito humano fundamental social da previdência social, cujo regime altamente protetivo, de nível constitucional, já foi exaustivamente demonstrado ao longo do presente trabalho.

Tal identidade ontológica reforça, ademais, as conclusões lançadas no capítulo anterior, no sentido de que i) o benefício de auxílio-acidente integra o rol dos benefícios previdenciários por incapacidade; ii) o rol de beneficiários dos três benefícios por incapacidade deve ser idêntico, sob pena de pecha de inconstitucionalidade, e iii) o elemento relevante juridicamente para efeitos de deflagração do direito a um dos benefícios por incapacidade é a presença de incapacidade laboral, pouco importando sua causa.

\subsection{Da fungibilidade entre os benefícios previdenciários por incapacidade laboral}

Dando um passo adiante, entendo que tal identidade ontológica, geradora do necessário regime jurídico único, disciplinador dos benefícios por incapacidade, como uma teoria geral voltada à proteção de tal contingência social, gera necessariamente uma outra conclusão, de índole material, mas que gerará vários reflexos sob o ponto de vista processual: existe uma caraterística ontológica, inerente aos benefícios por incapacidade, que diz respeito à fungibilidade entre eles. 
O que isso quer dizer?

Tal afirmação significa exatamente o que tem sido defendido no presente trabalho: não se podem estudar as prestações previdenciárias de forma estanque, divorciadas das contingências sociais protegidas por cada uma delas.

A metodologia de estudo do direito humano fundamental à previdência social deve partir de cada contingência social prevista constitucionalmente, buscando-se, em seguida, identificar as prestações sociais estatais voltadas à sua proteção, aglutinandoas em um regime jurídico protetivo comum, como uma teoria geral de cada grupo identificado, a gerar uma interpretação sistemática e teleológica das normas jurídicas disciplinadoras dos benefícios inseridos naquela contingência detectada.

Observe que não se está falando aqui de mera técnica processual, de fungibilidade entre pedidos formulados em juízo, tal como acontece com as tutelas possessórias (art. 920, do $\mathrm{CPC}^{374}$; art. 554, do $\left.\mathrm{CPC} / 15\right)$, mas de característica de direito material, inerente aos benefícios protetivos de uma mesma contingência social.

Certamente um dos efeitos mais importantes dessa característica ontológica, inerente aos benefícios por incapacidade, qual seja, a existência de um regime jurídico comum protetivo (fungibilidade entre os benefícios), é o reconhecimento de que não se deve interpretar o pedido formulado na esfera administrativa ou judicial de forma literal, ou seja, partindo da espécie de benefício postulada, e sim, considerando-se o gênero, no caso, como pedido envolvendo a concessão de um dos três benefícios por incapacidade previstos em lei.

A interpretação do pedido, na esfera previdenciária, deve levar em conta a contingência social protegida, e não a espécie de benefício postulada ${ }^{375}$.

Não é só. O reconhecimento dessa característica ontológica da fungibilidade entre os benefícios previdenciários por incapacidade irradia vários outros efeitos sobre os

\footnotetext{
374““A propositura de uma ação possessória em vez de outra não obstará a que o juiz conheça do pedido e outorgue a proteção legal correspondente àquela, cujos requisitos estejam provados."

${ }^{375}$ Interessante observar, nesse particular, como o INSS se encontra em estágio mais avançado do que o próprio Poder Judiciário, pois sequer possui dentre as opções de formulação de requerimento administrativo menção a cada espécie de prestação voltada à incapacidade laboral, substituídas pelo gênero "benefício por incapacidade" (vide, a propósito, o endereço eletrônico MINISTÉRIO DA PREVIDÊNCIA SOCIAL. Agendamento. Disponível em: <http://www.previdencia.gov.br/servicos-ao-cidadao/todos-osservicos/agendamento/>. Acesso em: 15 set. 2015), enquanto que, na via judicial, ainda hoje se nega a proteção previdenciária em razão da interpretação do pedido de acordo com a prestação requerida, e não conforme a contingência social protegida, com evidente perda de efetividade do direito humano fundamental social à previdência social. Interpretação essa equivocada, que não possui mais guarida diante da atual ordem constitucional.
} 
institutos processuais, notadamente os relacionados ao pedido, à garantia de acesso à justiça, às condições da ação, à sentença e ao princípio da congruência, servindo tais institutos como norte interpretativo à luz da previdência social como direito humano fundamental social.

Em assim sendo, não obstante concorde com o reconhecimento, levado a cabo pela doutrina pátria, da característica da fungibilidade entre os benefícios por incapacidade ${ }^{376}$, discordo que tal característica tenha contornos unicamente processuais, de mitigação da exigência processual da congruência entre a sentença e o pedido formulado, sendo a fungibilidade decorrência da identidade ontológica entre tais benefícios, e fruto da proteção a uma mesma contingência social, logo, a demandar um regime jurídico unificador de regência.

Também o Superior Tribunal de Justiça pacificou a questão, ainda sob o prisma processualista, em favor dos segurados, reconhecendo a possibilidade de concessão de benefício por incapacidade diverso do postulado na inicial, conforme ementas de elucidativos julgados:

PREVIDENCIÁRIO. AGRAVO REGIMENTAL NO RECURSO ESPECIAL. PEDIDO DE CONCESSÃO DE AUXÍLIO-DOENÇA. OBTENÇÃO DO BENEFÍCIO APOSENTADORIA POR INVALIDEZ. JULGAMENTO EXTRA PETITA. NÃO CARACTERIZAČ̃̃O. PRECEDENTES DO STJ. AGRAVO REGIMENTAL A QUE SE NEGA PROVIMENTO.

1. O STJ tem entendimento consolidado de que, em matéria previdenciária, deve-se flexibilizar a análise do pedido contido na petição inicial, não entendendo como julgamento extra ou ultra petita a concessão de benefício diverso do requerido na inicial, desde que o autor preencha os requisitos legais do benefício deferido.

2. No caso, o Tribunal a quo, em sede de apelação, ao reconhecer a incapacidade definitiva da segurada para o desempenho de suas funções, reformou sentença concessiva do benefício auxílio-doença para conceder o benefício da aposentadoria por invalidez.

3. Agravo regimental a que se nega provimento.

\footnotetext{
${ }^{376}$ A constatação do fenômeno da fungibilidade entre os benefícios previdenciários por incapacidade é feita, dentre outros, por José Antonio Savaris, da seguinte forma: "Como há um núcleo a ligar o requisito específico desses quatro benefícios da seguridade social - a redução ou inexistência de capacidade para o trabalho -, tem-se admitido uma espécie de fungibilidade dos pedidos que buscam sua concessão. Isso tem dois efeitos importantes. O primeiro refere-se à correspondência entre o requerimento administrativo e a petição inicial, à luz da condicionante de prévio indeferimento administrativo. $O$ segundo toca a correspondência entre a pretensão deduzida na petição inicial e a sentença à luz do princípio da adstrição ou congruência da sentença". SAVARIS, José Antonio. Direito processual previdenciário. 4. ed. Curitiba: Juruá, 2012. p. 70. Para maior aprofundamento, confira-se, outrossim, p. 69-72.

Também os seguintes autores: i) SERAU JUNIOR, Marco Aurélio. Curso de processo judicial previdenciário. 4. ed. São Paulo: Método, 2014. p. 66-67; ii) RUBIN, Fernando. Benefícios por incapacidade no Regime Geral da Previdência Social. Porto Alegre: Livr. do Advogado, 2014. p. 132-133; iii) AMADO, Frederico. op. cit., p. 959-960.
} 
(AgRg no REsp 1.305.049/RJ, Rel. Ministro MAURO CAMPBELL

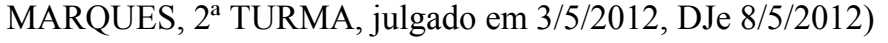

PREVIDENCIÁRIO E PROCESSUAL CIVIL. AGRAVO REGIMENTAL. AUSÊNCIA DE PREQUESTIONAMENTO. SÚMULA 211/STJ. INCAPACIDADE LABORAL. CONCESSÃO DE BENEFÍCIO DIVERSO DO PLEITEADO NA INICIAL. POSSIBILIDADE.

1. Acerca da alegada violação do art. $475, \S 2^{\circ}$, do CPC, a matéria não foi prequestionada, tampouco se provocou a manifestação da Corte de origem pela oposição de aclaratórios sobre a matéria.

2. É inadmissível Recurso Especial quanto a questão que, a despeito da oposição de Embargos Declaratórios, não foi apreciada pelo Tribunal de origem. Incidência da Súmula 211/STJ.

3. Não é extra ou ultra petita a decisão que concede benefício por incapacidade diverso do que se pleiteou na inicial, pois o juiz deve aplicar o direito incidente sobre a situação fática constatada. Precedentes do STJ: AgRg no REsp 868.911/SP, Rel. Ministro Arnaldo Esteves Lima, Quinta Turma, DJe 17.11.2008; REsp 541.695/DF, Rel. Ministro Paulo Gallotti, Sexta Turma, DJ 1.3.2004; REsp 412.676/RS, Sexta Turma, Relator Ministro Vicente Leal, DJe 19.12.2002; REsp 226.958/ES, Rel. Ministro Gilson Dipp, DJ 5.3.2001.

4. Agravo Regimental não provido.

(AgRg no AREsp 155.067/SP, Rel. Ministro HERMAN BENJAMIN, 2 TURMA, julgado em 22/5/2012, DJe 26/6/2012) (grifado)

O cerne da argumentação utilizada para efeitos de reconhecimento do caráter de fungibilidade entre os benefícios por incapacidade vem explicitado na seguinte passagem do voto do I. Ministro Relator Mauro Campbell Marques no bojo do julgamento do AgRg no REsp 1.305.049/RJ, a saber:

Deveras, o STJ tem entendimento consolidado de que, em matéria previdenciária, deve-se flexibilizar a análise do pedido contido na inicial, não entendendo como julgamento extra ou ultra petita a concessão de benefício diverso do requerido na inicial, desde que o autor preencha os requisitos legais do benefício deferido. (grifado)

Também são interessantes as seguintes observações feitas pelo I. Relator Ministro Napoleão Nunes Maia Filho no bojo do julgamento do AgRg no REsp 1.320.249/RJ, que tratava do reconhecimento da fungibilidade entre as aposentadorias por tempo de contribuição e por idade:

5. Cabe destacar que o Direito Previdenciário não deverá ser interpretado como uma relação de Direito Civil ou Direito Administrativo no rigor dos termos, mas sim como fórmula ou tutela ao hipossuficiente, ao carecido, ao excluído. Este deve, também, ser um dos nortes da jurisdição previdenciária. 


\begin{abstract}
6. Assim, tenho que o pleito contido na peça inaugural, mormente quando se trata de matéria previdenciária, deve ser analisado com certa flexibilidade. Desta forma, postulada na inicial a concessão de aposentadoria por tempo de contribuição, incensurável a decisão judicial que reconhece o preenchimento dos requisitos e concede ao autor o benefício de aposentadoria por idade, não incorrendo, dessa maneira, em julgamento extra ou ultra petita, tendo em vista a relevância da questão social que envolve a matéria. (grifado)
\end{abstract}

De se constatar, ademais, que não se trata de entendimento novo firmado pela referida Corte Superior, sendo que os primeiros julgados neste exato sentido datam de meado da década de 90, tendo como exemplos, dentre outros: REsp 64.006/SP, Rel. Min. Adhemar Maciel, DJ 7/8/1995; REsp 124.771/SP, Rel. Min. Anselmo Santiago, DJ 27/4/1998; REsp 177.267/SP, Rel. Min. Vicente Leal, DJ 21/9/1998.

De qualquer sorte, resta nítido o viés processualista adotado para efeitos de reconhecimento da possibilidade de concessão de benefício previdenciário por incapacidade diverso do postulado na exordial, a confundir a origem material $e$ constitucional do caráter de fungibilidade entre tais benefícios.

Tal orientação, não obstante represente um notório avanço em favor dos jurisdicionados, ainda fica aquém da exigência de máxima efetividade possível a ser garantida aos direitos humanos fundamentais (no caso, ao direito humano fundamental social à previdência social), uma vez que limita os reflexos processuais da fungibilidade decorrente da identidade da contingência social protegida unicamente à forma de se interpretar o princípio da congruência entre o pedido e a sentença.

Ao contrário, ao se compreender que tal fungibilidade é ontológica, inerente a cada grupo de benefícios aglutinados em razão da contingência social comum protegida, percebe-se que se trata de garantia de direito material, a irradiar diversos efeitos jurídicos benéficos, servindo tal característica como verdadeiro reforço de eficácia ao direito humano fundamental social à previdência social, com a ampliação do raio de aplicação das disposições legais garantidoras de cada benefício, bem como a ampliação da proteção na via jurisdicional.

Obtém-se, assim, aquele escopo tão difundido por Robert Alexy ${ }^{377}$ em suas obras que versam sobre os princípios jurídicos, qual seja, sua aplicação como "mandamentos de otimização".

${ }^{377}$ Vide, a propósito, o estudo realizado no bojo do capítulo 4. 
Tal reconhecimento irradia não apenas um, mas vários efeitos sobre o direito processual civil, todos garantidores de uma interpretação mais favorável de certas regras e princípios processuais em favor dos segurados: i) a propalada flexibilização na análise do princípio da congruência entre pedido e sentença; ii) uma interpretação do pedido formulado que leve em conta a contingência social protegida, ao invés da específica espécie de benefício postulada; iii) maiores poderes probatórios ao magistrado, na busca da verdade real; iv) uma certa flexibilização no tocante aos momentos de produção das provas nas demandas previdenciárias; v) menor rigor no tocante às regras procedimentais envolvendo a forma e as espécies de provas passíveis de serem produzidas; vi) possibilidade de uma melhor distribuição do ônus processual, de forma mais favorável aos segurados etc.

Assim é que, dentro da proposta ora trazida, de reconhecimento da fungibilidade entre os benefícios previdenciários por incapacidade como característica ontológica, decorrente da existência de uma identidade no tocante à contingência social protegida e, por consequência inexorável, de um regime jurídico único protetivo, chega-se a uma resposta diversa daquela apresentada pelo Superior Tribunal de Justiça quando do julgamento do AgRg no REsp 1.019.779/MG, cuja ementa é a seguinte:

PREVIDENCIÁRIO. CONCESSÃO DE BENEFÍCIO DIVERSO. DECISÃO EXTRA PETITA. OCORRÊNCIA. RECONHECIMENTO DE BENEFÍCIO FULCRADO EM FATO DIVERSO DO ALEGADO NA INICIAL. PREJUÍZO À DEFESA.

1. A jurisprudência desta Corte entende que não há nulidade quando o magistrado, verificando o implemento dos requisitos necessários, concede benefício diverso do pretendido na inicial.

2. Contudo, nos casos em que o benefício deferido não é diverso do requerido e que a concessão opera-se com fulcro em fato distinto daquele aventado na inicial, há de se reconhecer a violação aos limites da lide, com manifesto prejuízo à defesa.

3. Agravo regimental provido.

(AgRg no REsp 1.019.779/MG, Rel. Ministro NEFI CORDEIRO, 6a TURMA, julgado em 02/12/2014, DJe 3/2/2015) (grifado)

O cerne do raciocínio jurídico empregado pelo I. Ministro Relator Nefi Cordeiro é extraído da seguinte passagem de seu voto:

Nota-se que, para a não configuração de julgamento extra-petita, este Tribunal considera alguns requisitos para o reconhecimento de benefício diverso daquele inicialmente solicitado na inicial, quais sejam: i) que o benefício solicitado seja diferente do concedido, ou seja, no caso das ementas acima colacionadas, os beneficiários pugnavam pelo recebimento de auxílio-acidente e foi-lhes concedida aposentaria por invalidez; ii) que o fato objeto da solicitação inicial 
permaneça o mesmo, quer dizer, no caso de solicitação de auxílio-acidente por queimaduras, eventualmente, até poderá ser concedida a aposentadoria por invalidez, desde que a incapacidade laboral tenha sido provocada pelas queimaduras, jamais por outro fato. Portanto, tem-se que o caso em exame veicula situação diversa, apesar de aparentemente semelhante, daquela pontuada pelo Ministério Público. Isso porque, conforme analisado, o caso em apreço não se revestiu dos requisitos delineados nas ementas colacionadas nas razões recursais. A uma, porque o benefício solicitado foi exatamente o concedido. A duas, porque a concessão do benefício calcou-se em fato diverso do pretendido pelo autor da demanda. Com efeito, a concessão de benefício fulcrado em motivo diverso do requerido pelo autor inviabiliza uma intervenção exauriente, indo de encontro, inclusive, com princípios como contraditório e ampla defesa, impondo, assim, uma situação desleal e injusta para a defesa. (grifado)

Certamente uma visão processualista do fenômeno da fungibilidade entre os benefícios previdenciários por incapacidade gera tal conclusão, pois limita seu campo de atuação unicamente à forma de interpretação do princípio da congruência em sede previdenciária.

Ao passo que, dentro do aqui defendido espectro amplo de abrangência da fungibilidade como reforço eficacial ao direito humano fundamental social à previdência social, decorrente de um regime protetivo único, de nível constitucional, a conclusão deve ser diversa, pois seu espectro de atuação influencia, inclusive, a interpretação de princípios processuais basilares constitucionais, como o devido processo legal, o contraditório e a ampla defesa, a serem compreendidos dentro de um sistema processual que deve garantir e efetivar direitos humanos fundamentais sociais, atuando como garantia dos cidadãos frente à inércia estatal em tal campo de atuação. Ou seja, por se tratar de direito humano fundamental garantido constitucionalmente, o direito à previdência social modula o alcance e abrangência de outras garantias constitucionais, mediante a aplicação dos mecanismos da ponderação e da proporcionalidade, em se tratando de aparente colisão entre princípios, nos exatos termos do defendido por Alexy ${ }^{378}$ e Virgílio Afonso da Silva ${ }^{379}$, inclusive com a aplicação do ônus argumentativo de se justificar a restrição ao direito fundamental no caso concreto.

Em assim sendo, trazidos fatos novos ao longo da instrução processual, com a produção de provas submetida ao crivo do contraditório, com oportunidade de manifestação pelo réu, restam cumpridas as exigências decorrentes dos princípios constitucionais processuais supra elencados, não havendo que se falar em qualquer mácula no caso de reconhecimento e concessão da prestação inserida no direito humano

\footnotetext{
${ }^{378}$ ALEXY, Robert. Teoria dos direitos fundamentais, cit.
}

${ }^{379}$ SILVA, Virgílio Afonso da. op. cit. 
fundamental social assegurado pela constituição, e sim, justamente, na concretização da força normativa da constituição.

É o que procurarei demonstrar no próximo capítulo, com a análise das derradeiras consequências processuais favoráveis decorrentes do reconhecimento da fungibilidade entre os benefícios previdenciários por incapacidade como fenômeno ontológico, material. 


\section{DA CONTINGÊNCIA SOCIAL DA INCAPACIDADE LABORAL E SUA TUTELA JURISDICIONAL: A MÁXIMA EFETIVAÇÃO POSSÍVEL DO DIREITO HUMANO FUNDAMENTAL}

\subsection{Introdução}

Procurei demonstrar, nos capítulos anteriores, como o estudo dos benefícios previdenciários por incapacidade sob a premissa do direito à previdência social como direito humano fundamental social leva a uma interpretação maximizante de sua eficácia, notadamente sob o binômio Teoria Crítica/neoconstitucionalismo.

Isso ocorre porque, sendo a previdência social um direito humano fundamental social, previsto expressamente na Constituição, possui uma série de garantias nela plasmadas, voltadas à sua efetividade, dentro do atual contexto neoconstitucionalista, pelo qual os direitos garantidos constitucionalmente devem ser prioritariamente efetivados pelos poderes constituídos (caráter jusfundamental, conforme Jorge Reis Novais).

Ademais, sob a premissa da Teoria Crítica, o direito à previdência social surge dentro de um contexto histórico de lutas pelo reconhecimento do ser humano como sujeito de direitos, em um processo evolutivo protetivo necessariamente universalizante.

O binômio Teoria Crítica/neoconstitucionalismo leva ao estudo das prestações previdenciárias a partir do elemento da contingência social deflagradora de cada necessidade protegida, com a decorrência inexorável da aglutinação de algumas prestações inseridas dentro de um regime jurídico único, formado exatamente a partir de cada contingência social comum deflagradora da proteção estatal. Trata-se do fenômeno da fungibilidade ontológica entre certas espécies de benefícios.

E, se ao analisar a questão da proteção jurisdicional dos direitos fundamentais sociais chegou-se à conclusão, inarredável, de que tais direitos contam com um regime jurídico altamente protetivo - na verdade, um regime jurídico comum protetivo de todos os direitos humanos fundamentais -, com plena sindicabilidade judicial, a mesma conclusão passa a ser o ponto de partida da análise dos benefícios por incapacidade e sua tutela jurisdicional. 
Assim, no estudo dedicado à proteção jurisdicional dos trabalhadores no caso de ocorrência da contingência social da incapacidade laboral decorrente de doença e/ou invalidez (art. 201, I, da Constituição), há que se ter em mente que se está tratando da proteção de direito humano fundamental social, garantido expressamente pela Lei Maior.

Logo, a metodologia necessária a tal abordagem diz respeito, invariavelmente, ao estudo dos aparentes conflitos existentes entre o direito humano fundamental à previdência social e os princípios processuais constitucionais conformadores dos principais institutos fixados pela legislação ordinária em termos de acesso à justiça e modelo processual a ser aplicado para o deslinde da controvérsia ${ }^{380}$.

Tratando-se de choques entre direitos humanos fundamentais garantidos constitucionalmente, será da apreciação de tais conflitos, sempre aparentes ${ }^{381}$, analisados dentro de cada assunto, que se obterá o maior sentido e alcance possíveis para a proteção jurisdicional do direito humano fundamental à previdência social, sem a aniquilação ou subjugação dos direitos fundamentais de índole processual, os quais restarão assegurados para todos os potenciais participantes da relação jurídica adjetiva (autor e réu).

Não é preciso muito esforço para se inferir que as conclusões a serem sacadas neste estudo serão, no mais das vezes, diversas daquelas obtidas em um estudo estanque dos princípios processuais informadores de nosso sistema adjetivo, dentro de uma abordagem disciplinar clássica.

Isso se deve a que os processualistas analisam tais princípios unicamente dentro da lógica processual, ou seja, com enfoque exclusivo no instrumento garantidor necessário ao pronunciamento do Estado-juiz.

\footnotetext{
${ }^{380}$ Retomo, aqui, os ensinamentos de Robert Alexy e Virgílio Afonso da Silva, no concernente ao estudo e solução dos aparentes conflitos existentes entre princípios jurídicos, figura normativa da qual se revestem os principais direitos envolvidos na questão da proteção jurisdicional do direito humano fundamental à previdência social, dentro da contingência social da incapacidade laboral, a saber: i) direito à previdência social (art. 201, I, da Constituição); ii) inafastabilidade do controle jurisdicional de ameaça ou lesão a direito (art. 5 $5^{\circ}, \mathrm{XXXV}$, da Constituição); iii) devido processo legal (art. 5, LIV, da Constituição); iv) contraditório e ampla defesa (art. $5^{\circ}, \mathrm{LV}$, da Constituição). Para tanto, sugiro o retorno aos estudos desenvolvidos no capítulo 4, item 4.2.1. Interessante notar, outrossim, que o aparente conflito se dá entre direito fundamental social e direitos fundamentais individuais, para o que foi de extremo relevo a demonstração da ausência de hierarquia normativa entre as diversas dimensões de direitos humanos fundamentais, contraposta à existência de um regime jurídico protetivo único, de índole constitucional. Para tanto, retomar os estudos desenvolvidos nos capítulos 1, itens 1.3 e 1.5; 2, item 2.4; e 3, item 3.4.

${ }^{381} \mathrm{De}$ se recordar que os conflitos entre princípios jurídicos não são reais, logo, não levam ao afastamento de um deles para a aplicação do outro. Não se trata de antinomia, mas, de uma necessária análise conjunta, para se extrair o campo de alcance e aplicação de cada princípio. Ainda mais entre aqueles princípios arrolados expressamente pela Constituição, em face da qual se aplica o entendimento hermenêutico de sua unidade.
} 
Na presente obra, como a perspectiva é de direito material, dentro do contexto dos direitos humanos fundamentais, os princípios processuais sofrerão o influxo do direito material fundamental logo em sua interpretação, enfatizando-se a força normativa do direito material, tudo com vistas à sua maior eficácia possível. Trata-se de uma análise interdisciplinar, com ganhos em termos de sistematização e coerência interna do sistema jurídico.

\subsection{Esclarecimentos prévios}

Antes de adentrar nas análises concretas, reputo necessários alguns esclarecimentos conceituais prévios, para a correta compreensão das análises a serem desenvolvidas em seguida.

A primeira delas diz respeito à forma de interpretação do direito humano fundamental à previdência social (e dos demais princípios colidentes).

Utilizo nessa análise o mesmo método de interpretação dos direitos humanos fundamentais como princípios, levado a cabo por Virgílio Afonso da Silva, qual seja, partindo de um suporte fático amplo e da teoria externa em termos de sua restrição ${ }^{382}$.

Isso significa que, prima facie, os direitos humanos fundamentais não encontram limites ou resistências no tocante ao seu sentido e alcance, decorrendo tais óbices do aparente conflito com outros direitos fundamentais, em cada caso concreto, e cuja solução envolve a aplicação das técnicas da proporcionalidade ou do sopesamento.

Logo, por serem prescritos, em sua maioria, por normas jurídicas revestidas da natureza de princípios, os direitos humanos fundamentais - inclusive e notadamente os sociais - são direitos prima facie, garantidos dentro das máximas possibilidades fáticas e jurídicas existentes no momento de sua aplicação (mandamentos de otimização).

O sentido e o alcance do direito humano fundamental à previdência social (e dos demais princípios colidentes) serão sacados, em cada caso concreto, da aplicação das técnicas da proporcionalidade e do sopesamento sobre os princípios jurídicos colidentes envolvidos em cada situação fática.

Em segundo lugar, deve-se entender minimamente o que vem a ser o princípio processual basilar do "devido processo legal".

\footnotetext{
${ }^{382}$ Remeto o leitor às referências trazidas no capítulo 4 .
} 
Por não se tratar de uma obra processualista, o que se deve ter em mente é o seu duplo significado: i) devido processo legal processual (procedural due process), que significa a existência de um sistema normativo processual prévio, fixado em lei, a que as pessoas possuam acesso antes do ajuizamento de uma ação, como impedimento de utilização de procedimentos ad hoc; ii) devido processo legal material (substantive due process), que diz respeito à necessidade de garantia aos direitos humanos fundamentais, a assegurar o poder de controle da atividade legislativa e executiva pelo Poder Judiciário ${ }^{383} 384$.

Em terceiro lugar, é de se ter em mente que o princípio do devido processo legal abarca os outros princípios processuais basilares, estruturantes de nosso sistema processual civil pátrio, sobre eles exercendo influência ${ }^{385}$, notadamente nestes: i) princípios constitucionais expressos da inafastabilidade do controle jurisdicional de ameaça ou lesão a direito (art. $5^{\circ}, \mathrm{XXXV)}$ e do contraditório e da ampla defesa ${ }^{386}$ (art. $\left.5^{\circ}, \mathrm{LV}\right)$; ii) princípios constitucionais implícitos da congruência e dispositivo.

383“'O devido processo legal é direito fundamental que pode ser compreendido em duas dimensões. Há o devido processo legal formal ou procedimental, cujo conteúdo é composto pelas garantias processuais que vimos no item antecedente: direito ao contraditório, ao juiz natural, a um processo com duração razoável, etc. Trata-se da dimensão mais conhecida do devido processo legal. Nos EUA, desenvolveu-se a dimensão substancial do devido processo legal. Um processo devido não é apenas aquele em que se observam exigências formais: devido é o processo que gera decisões jurídicas substancialmente devidas". DIDIER JUNIOR, Fredie. Curso de direito processual civil. 14. ed. Salvador: JusPODIVM, 2012. v. 1, p. 49-50.

${ }^{384}$ Para aprofundamento acerca do conceito e da dupla faceta do princípio constitucional do devido processo legal, confira-se, dentre os processualistas: i) SERAU JUNIOR, Marco Aurélio. op. cit., p. 73-136; ii) DINAMARCO, Candido Rangel. Instituições de direito processual civil. 4. ed. São Paulo: Malheiros Ed., 2004. v. 1, p. 244-248; iii) DIDIER JUNIOR, Fredie. Curso de direito processual civil, cit., v. 1, p. 45-56.

385“A expressa garantia do due process of law, contida no inc. LIV do art. $5^{\circ}$ da Constituição Federal, tem o significado sistemático de fechar o círculo das garantias e exigências constitucionais relativas ao processo, numa fórmula sintética destinada a afirmar a indispensabilidade de todas e reafirmar a autoridade de cada uma. Esse enunciado explícito vale ainda como norma de encerramento portadora de outras exigências não tipificadas em fórmulas mas igualmente associadas à ideia democrática que deve prevalecer na ordem processual $\left(\right.$ art. $5^{\circ}, \S 2^{\circ}$ ). (...) O perfil de processo que resulta dessa garantia é o do processo justo e équo que, na voz da mais moderna doutrina, é o processo regido por garantias mínimas de meios e de resultado, com emprego de instrumental técnico-processual adequado e conducente a uma tutela adequada e efetiva (Luigi Paolo Comoglio). O contexto de garantias tipificadas e atípicas contidas na fórmula due process of law oferece aos litigantes um direito ao processo justo, com oportunidades reais e equilibradas". DINAMARCO, Candido Rangel. Instituições de direito processual civil, cit., v. 1, p. 244-247.

386، OO princípio do contraditório é reflexo do princípio democrático na estruturação do processo. Democracia é participação, e a participação no processo opera-se pela efetivação da garantia do contraditório. $\mathrm{O}$ princípio do contraditório deve ser visto como exigência para o exercício democrático de um poder. $\mathrm{O}$ princípio do contraditório pode ser decomposto em duas garantias: participação (audiência; comunicação; ciência) e possibilidade de influência na decisão. A garantia da participação é a dimensão formal do princípio do contraditório. Trata-se da garantia de ser ouvido, de participar do processo, de ser comunicado, poder falar no processo. Esse é o conteúdo mínimo do princípio do contraditório e concretiza a visão tradicional a respeito do tema. De acordo com esse pensamento, o órgão jurisdicional efetiva a garantia do contraditório simplesmente ao dar ensejo à ouvida da parte. Há, porém, ainda, a dimensão substancial do princípio do contraditório. Trata-se do 'poder de influência'. Não adianta permitir que a parte simplesmente participe do processo. Apenas isso não é o suficiente para que se efetive o princípio do contraditório. É necessário que se permita que ela seja ouvida, é claro, mas em condições de poder influenciar a decisão do 
De se esclarecer, desde já, que os princípios processuais basilares possuem por escopos maiores os seguintes: i) servir de limites aos poderes estatais, inclusive, aos instrutórios e decisórios dos magistrados; ii) impedir surpresas para cada uma das partes ao longo da instrução processual e quando da prolação das decisões judiciais; iii) garantir o amplo acesso à justiça, bem como a sua efetividade em termos de proteção aos direitos materiais ${ }^{387}$.

Também quero deixar claro que a chave argumentativa principal a influenciar o deslinde das questões a serem estudadas a seguir diz respeito ao instituto da contingência social, já que se trata do elemento deflagrador do direito material à previdência social. No caso em tela, a contingência social da incapacidade laboral é a deflagradora do direito a uma das três prestações estatais fixadas em lei: aposentadoria por invalidez, auxíliodoença ou auxílio-acidente. Aqui também fica evidente a influência do caráter de fungibilidade material para o deslinde das questões.

\subsection{Análises processuais}

Três serão as análises processuais a serem empreendidas: i) forma de interpretação do pedido judicial e do princípio da inércia da jurisdição; ii) forma de interpretação do princípio da congruência entre pedido e sentença; iii) forma de interpretação dos poderes instrutórios do magistrado e dispositivo e da produção da prova pericial médica para constatação da (in)capacidade laboral.

\subsubsection{Direito à previdência social e pedido inicial}

A primeira das análises diz respeito à forma como deve ser interpretado o pedido inicial envolvendo a proteção do direito humano fundamental à previdência social, diante da alegação de ocorrência da contingência social da incapacidade laboral decorrente de doença e/ou invalidez.

magistrado”. DIDIER JUNIOR, Fredie. Curso de direito processual civil, cit., v. 1, p. 56-57. Confira-se, outrossim, DINAMARCO, Candido Rangel. Instituições de direito processual civil, cit., v. 1, p. 214-225.

387، As promessas e limitações residentes nas diversas garantias constitucionais e interligadas pelo fio condutor que é o devido processo legal têm um só e único objetivo central, que é o acesso à justiça. $\mathrm{O}$ processo justo, celebrado com meios adequados e produtor de resultados justos, é o portador de tutela jurisdicional a quem tem razão, negando proteção a quem não a tenha. Nem haveria justificativa para tanta preocupação com o processo, não fora para configurá-lo, de aperfeiçoamento em aperfeiçoamento, como autêntico instrumento de condução à ordem jurídica justa. Tal é o que se propõe quando se fala em processo civil de resultados". DINAMARCO, Candido Rangel. Instituições de direito processual civil, cit., v. 1, p. 248. 
Assim é porque, no atual e vigente sistema processual civil pátrio, vigem as regras da determinação e especificação dos pedidos formulados na petição inicial ${ }^{388}{ }^{389}$, bem como da interpretação literal e restritiva dos mesmos 390 391, fundadas nos princípios processuais estruturantes da inércia da jurisdição ${ }^{392}$, dispositivo ${ }^{393}$ e da não surpresa com relação à parte contrária.

Trata-se, portanto, de visão fulcrada em uma análise interna do sistema processual civil, buscando-se o máximo de segurança em termos de pronunciamento judicial por parte do Estado-juiz, de molde a evitar a prolação de decisões que envolvam fatos e aspectos jurídicos não abordados pela parte autora em sua petição inicial. É o máximo possível de garantia quanto a limitação da atividade jurisdicional e da não surpresa em relação à parte contrária.

Sucede que o sistema processual tem por escopo a pacificação social ${ }^{394}$, servindo de instrumento $^{395}$ à efetividade dos direitos materiais violados, que devem ser assegurados pelo Estado-juiz.

Em assim sendo, há que se encontrar uma solução compatibilizadora entre os limites e contornos precisos de que devem se revestir os pedidos iniciais e o escopo maior de efetividade dos direitos materiais buscados pela via processual.

Dentro de nosso objeto de estudo, qual seja, uma análise dos benefícios previdenciários por incapacidade laboral, a chave para a solução de tal equação está na

388“"O pedido deve ser certo ou determinado" (art. 286, caput, $1^{\mathrm{a}}$ parte, do CPC). No novo CPC (Lei n. 13.105/15), a redação ficou da seguinte forma: "O pedido deve ser determinado" (novo art. 324).

${ }^{389}$ A propósito, confira-se: "Entende-se por certo o pedido expresso, pois não se admite que possa o pedido do autor ficar apenas implícito. Já a determinação se refere aos limites da pretensão. O autor deve ser claro, preciso, naquilo que espera obter da pretensão jurisdicional". THEODORO JÚNIOR, Humberto. Curso de direito processual civil. 43. ed. Rio de Janeiro: Forense, 2005. v. 1, p. 395.

390“'Os pedidos são interpretados restritivamente compreendendo-se, entretanto, no principal os juros legais" (art. 293, do CPC). No novo CPC (Lei n. 13.105/15) a redação ficou da seguinte forma: "O pedido deve ser certo. $\S 1^{\circ}$. Compreendem-se no principal os juros legais, a correção monetária e as verbas de sucumbência, inclusive os honorários advocatícios" (novo art. 322).

${ }^{391}$ Confira-se: "Como será examinado adiante, não se admite, como regra, o pedido implícito nem se permite interpretação extensiva do pedido. 'Não se admite, a teor da melhor técnica, pedido obscuro, dúbio e vago, substituído parcial ou integralmente, através de expressões elípticas, por exemplo, condenar o réu 'no que couber' ou, ainda, 'no que reputar justo', e outras, infelizmente comuns"'. DIDIER JUNIOR, Fredie. Curso de direito processual civil, cit., v. 1, p. 454.

392“Nenhum juiz prestará a tutela jurisdicional senão quando a parte ou o interessado a requerer, nos casos e formas legais" (art. $2^{\circ}$, do CPC, sem correspondência no novo CPC, Lei n. 13.105/15). Trata-se de um dos instrumentos mais eficazes em termos de limitação do poder jurisdicional do Estado.

${ }^{393}$ Também conhecido como princípio da liberdade das partes. Confira-se, a propósito, DINAMARCO, Candido Rangel. Instituições de direito processual civil, cit., v. 1, p. 225-235.

394“Nesse quadro é que se avulta a grande valia social do processo como elemento de pacificação. O escopo de pacificar pessoas mediante a eliminação de conflitos com justiça é, em última análise, a razão mais profunda pela qual o processo existe e se legitima na sociedade". DINAMARCO, Candido Rangel. Instituições de direito processual civil, cit., v. 1, p. 128.

${ }^{395}$ Trata-se da consagrada visão instrumental do processo, valendo conferir, para tanto, o livro DINAMARCO, Candido Rangel. A instrumentalidade do processo. 15.ed. São Paulo: Malheiros ed., 2013. 


\section{utilização da contingência social da incapacidade laboral como vetor interpretativo do pedido formulado na petição inicial.}

Ou seja, não cabe exigir - em uma demanda previdenciária que tenha na incapacidade laboral a causa de pedir de uma prestação previdenciária estatal garantidora de tal necessidade social (=pedido) - que seja arrolada qual a espécie de prestação estatal a ser concedida mediante a prolação de uma tutela jurisdicional de mérito, até mesmo porque as prestações passíveis de serem concedidas como medida de concretização do direito humano fundamental à previdência social estão arroladas prévia e expressamente em lei (aposentadoria por invalidez, auxílio-doença ou auxílio-acidente).

O que se deve exigir na petição inicial é a descrição pormenorizada dos males incapacitantes (um, alguns ou vários), a forma pela qual tais problemas levam à incapacidade laboral diante das funções desempenhadas pelo postulante, e o pedido de condenação do ente estatal na concessão de um dos três benefícios previdenciários por incapacidade previstos em lei, de acordo com o grau e o alcance de incapacidade laboral comprovados ao longo da instrução processual.

Somente assim restará garantida a máxima efetividade possível ao direito humano fundamental à previdência social, como direito material, resguardando-se, ao mesmo tempo, os direitos processuais de ambas as partes do processo (segurado e INSS), respeitando-se as exigências de certeza e determinação no pedido inicial, mas sem que tais deveres inviabilizem a obtenção, pela via judicial, do direito humano fundamental negado.

De se recordar, neste ponto, que os próprios princípios constitucionais processuais da inafastabilidade do controle jurisdicional de ameaça ou lesão a direito (art. $5^{\circ}, \mathrm{XXXV}$ ), do devido processo legal (art. 5\%, LIV) e do contraditório e ampla defesa (art. $5^{\circ}$, LV) asseguram ao titular do direito material violado no caso concreto o acesso amplo e irrestrito ao Poder Judiciário, como forma de fazer valer seu direito, mediante a obtenção de uma tutela jurisdicional adequada, dotada de caráter vinculante e coercitivo, logo, que deve ser cumprida e efetivada pela parte vencida ${ }^{396}$. O que se deve observar é o fato de que

\footnotetext{
${ }^{396}$ Tal preocupação foi objeto de abordagem por DINAMARCO: "Mas essa cautela do juiz não deve ir além dos casos em que haja dúvida invencível quanto às intenções do autor. Não seria legítimo converter o zelo pela integridade da máxima ne eat judex ultra vel extra petita partium em motivo para denegar justiça mediante julgamentos citra petita. Que o juiz jamais conceda coisas não pedidas ou em quantidade maior que a pedida, ou por fundamento diverso do invocado pelo autor (arts. 128 e 460), mas também que não se negue a decidir sobre todo o pedido e por todos os fundamentos trazidos. Não sendo suficientemente forte a dúvida sobre a extensão da demanda, a solene promessa constitucional de acesso à justiça impede as opções pelo mais estrito (Const., art. $5^{\circ}$, inc. XXXV). Entre dois riscos opostos - o de ir além e o de ficar aquém dos reais limites da demanda do autor - sendo eles razoavelmente equilibrados, é dever do juiz a assunção
} 
o processo configura um procedimento em contraditório, logo, com a participação de partes antagônicas, às quais devem ser assegurados os instrumentos e meios processuais necessários ao exercício dos direitos, faculdades, ônus e deveres fixados previamente em lei, com vistas à garantia da paridade de armas.

Logo, o sistema processual é estruturado de modo a garantir uma resposta estatal efetiva e impessoal, sem quaisquer privilégios ou arbitrariedades. É dentro deste contexto que atuam os princípios processuais constitucionais supra elencados, jamais podendo ser utilizados como fundamento para a negativa de proteção a direitos materiais legítimos, ainda mais de envergadura constitucional, como são os direitos humanos fundamentais. Apenas possuem uma faceta de controle para se coibir eventuais abusos e pedidos descabidos por aquele que não possui direito material a ser assegurado pelo Estado-juiz.

Por fim, de se salientar que a ação judicial tendente à obtenção de benefício previdenciário por incapacidade possui, como antecedente necessário, um prévio processo administrativo instaurado e decidido perante a autoridade administrativa competente (no caso, inserida na estrutura administrativa do INSS, como autarquia federal), de forma desfavorável aos interesses do trabalhador filiado e segurado do regime geral de previdência social.

Forçoso reconhecer, do exposto, que a parte ré da relação jurídica processual já teve a oportunidade de receber e analisar previamente o pedido agora formulado em juízo, negando-o, o que significa que as exigências voltadas a não surpresa devem ser mitigadas, em prol de uma maior garantia e efetividade ao direito humano fundamental à previdência social, uma vez que a parte ré já teve contato prévio e profundo com os fatos objeto da controvérsia.

Assim, no choque aparente entre direitos humanos fundamentais sociais (previdência social) e individuais (princípios processuais estruturantes), há que prevalecer a interpretação voltada à máxima efetividade possível: i) do direito humano fundamental à

do primeiro, sob pena de denegar justiça. O risco de extrapolar os limites da demanda inicial fica neutralizado quando as próprias partes houverem discutido amplamente a causa, a ponto de se manifestarem explicitamente sobre a parte do pedido ou sobre os fundamentos sobre cuja inclusão naquela o juiz possa ter alguma dúvida. Em casos assim, a garantia constitucional do contraditório não fica maculada”. DINAMARCO, Candido Rangel. Instituições de direito processual civil, cit., v. 2, p. 135-136. 
previdência social ${ }^{397}$; ii) da própria finalidade do processo, que é a prolação de uma tutela jurisdicional de mérito, adequada e pacificadora dos conflitos sociais.

Não obstante por fundamentos diversos, em tal sentido restou consagrada a jurisprudência do Superior Tribunal de Justiça, ao firmar a tese da necessária interpretação lógico-sistemática da petição inicial, de modo a extrair de seu conjunto o pedido formulado em sede de proteção ao direito humano fundamental à previdência social, a conferir:

AGRAVO REGIMENTAL NO RECURSO ESPECIAL. CIVIL.
PREVIDÊNCIA PRIVADA. VIOLAÇÃO DO ART. 535 DO CPC. NÃO
OCORREENCIA. JULGAMENTO EXTRA PETITA. NÃO OCORRÊNCIA.
BENEFÍCIO PREVIDENCIÁRIO COMPLEMENTAR. REVISÃO DE RENDA
MENSAL INICIAL. PRESCRIÇÃO. RELAÇÃO DE TRATO SUCESSIVO.

1. Não há falar em negativa de prestação jurisdicional se o tribunal de origem motiva adequadamente sua decisão, solucionando a controvérsia com a aplicação do direito que entende cabível à hipótese, apenas não no sentido pretendido pela parte.

2. Não há falar em julgamento extra petita quando o órgão julgador não afronta os limites objetivos da pretensão inicial, tampouco concede providência jurisdicional diversa da requerida, respeitando o princípio da congruência. Ademais, os pedidos formulados devem ser examinados a partir de uma interpretação lógico-sistemática, não podendo o magistrado se esquivar da análise ampla e detida da relação jurídica posta, mesmo porque a obrigatória adstrição do julgador ao pedido expressamente formulado pelo autor pode ser mitigada em observância aos brocardos da mihi factum dabo tibi ius (dá-me os fatos que te darei o direito) e iura novit curia (o juiz é quem conhece o direito).

(...)

5. Agravo regimental não provido.

(AgRg no REsp 1.385.134/RN, Rel. Ministro RICARDO VILLAS BÔAS CUEVA, $3^{\text {a }}$ TURMA, julgado em 19/3/2015, DJe 31/3/2015)

PREVIDENCIÁRIO. APOSENTADORIA POR INVALIDEZ. CARACTERIZAÇÃO DA INCAPACIDADE LABORATIVA, NOS TERMOS DO ARTIGO 42 DA LEI 8.213/91. CONCESSÃO DO BENEFÍCIO. ASSISTÊNCIA PERMANENTE. ARTIGO 45 DA LEI 8.213/91. OBSERVÂNCIA. LAUDO PERICIAL.

1. O pedido feito com a instauração da demanda emana de interpretação lógico-sistemática da petição inicial, não podendo ser restringido somente ao capítulo especial que contenha a denominação "dos pedidos", devendo ser levado em consideração, portanto, todos os requerimentos feitos ao longo da peça inaugural, ainda que implícitos.

2. O juiz, ao acolher um dos pedidos implícitos veiculados pela demandante, que expôs expressamente a situação de dependência e necessidade de assistência permanente de parentes e amigos, não julgou de modo extra ou ultra petita,

\footnotetext{
397“"No princípio, portanto, o significado da cláusula do devido processo legal era exclusivamente o de um anteparo à ação estatal que pudesse violar o trinômio vida, propriedade e liberdade. Contudo, atualmente o devido processo legal impõe-se muito mais como uma cláusula que determina a implementação ou efetivação dos direitos fundamentais do que uma mera proteção dos mesmos". SERAU JUNIOR, Marco Aurélio. op. cit., p. 118.
} 
quando concedeu o acréscimo de $25 \%$ no valor da aposentadoria por invalidez do segurado, nos termos do artigo 45 da Lei 8.213/91.

3. Agravo regimental a que se nega provimento.

(AgRg no REsp 891.600/RJ, Rel. Ministro VASCO DELLA GIUSTINA (DESEMBARGADOR CONVOCADO DO TJ/RS), $6^{\text {a }}$ TURMA, julgado em 15/12/2011, DJe 6/2/2012) (grifado)

Única observação crítica a ser feita está no sentido da desnecessidade de se confrontar as regras da certeza e determinação do pedido, bem como de sua interpretação restrita, em se tratando de lide previdenciária, devendo-se interpretar o(s) pedido(s) formulado(s) levando-se em conta a contingência social geradora da necessidade de proteção estatal para, a partir daí, fixar o benefício previdenciário cabível no caso concreto, com o pleno respeito e observância ao contraditório e à ampla defesa em favor do INSS.

\subsubsection{Direito à previdência social e princípio da congruência ${ }^{398}$}

Questão processual umbilicalmente ligada ao pedido inicial e sua interpretação $0^{399}$ diz respeito à necessária adstrição do magistrado ao pedido formulado na exordial quando do julgamento ${ }^{400}$, uma vez mais em atenção aos princípios processuais constitucionais basilares da inércia da jurisdição, dispositivo e da não surpresa, impedindo-se que o juiz analise questões diversas daquelas estritamente trazidas ao processo pelas partes.

\footnotetext{
398“"Como, ainda, a sentença não pode versar senão sobre o que pleiteia o demandante, forçoso é admitir que o pedido é também o limite da jurisdição (arts. 128 e 460). Iudex secundum allegata partium iudicare debet. (...) A segunda afirmativa traduz o princípio da congruência entre o pedido e a sentença (CF, art. $\left.5^{\circ}, \mathrm{LV}\right)$. É preciso que o objeto do processo fique bem claro e preciso para que sobre ele possa manifestar-se a defesa do réu. Daí por que, sendo o objeto da causa do pedido do autor, não pode o juiz decidir fora dele, sob pena de surpreender o demandado e cercear-lhe a defesa, impedindo-lhe o exercício do pleno contraditório. O princípio da congruência, que impede o julgamento fora ou além do pedido, insere-se, destarte, no âmbito maior da garantia do devido processo legal. (...) Em síntese, o pedido é a condição e o limite da prestação jurisdicional, de maneira que a sentença, como resposta ao pedido, não pode ficar aquém das questões por ele suscitadas (decisão citra petita) nem se situar fora delas (decisão extra petita), nem tampouco ir além delas (decisão ultra petita)". THEODORO JÚNIOR, Humberto. op. cit., v. 1, p. 553. Para maior aprofundamento, confiram-se: i) DINAMARCO, Candido Rangel. Instituições de direito processual civil, cit., v. 3, p. 273-292; ii) DIDIER JUNIOR, Fredie; BRAGA, Paula Sarno; OLIVEIRA, Rafael. Curso de direito processual civil. 7. ed. Salvador: JusPODIVM, 2012. v. 2, p. 311-329.

${ }^{399}$ Esta ligação íntima restou muito bem captada por Fredie Didier Júnior: "Note que os requisitos do pedido (certeza, determinação, clareza e coerência) são os mesmos requisitos da sentença (cf. v. 2 deste Curso). Se o pedido é um projeto de sentença, nada mais razoável do que exigir dessa os mesmos requisitos exigidos daquele". DIDIER JUNIOR, Fredie. Curso de direito processual civil, cit., v. 1, p. 455.

${ }^{400 “} \mathrm{O}$ juiz decidirá a lide nos limites em que foi proposta, sendo-lhe defeso conhecer de questões, não suscitadas, a cujo respeito a lei exige a iniciativa da parte" (art. 128, do CPC). Tal redação restou parcialmente modificada no novo CPC (Lei n. 13.105/15) para os seguintes termos: "O juiz decidirá o mérito nos limites propostos pelas partes, sendo-lhe vedado conhecer de questões não suscitadas a cujo respeito a lei exige iniciativa da parte" (novo art. 141).
} 
Os objetivos maiores de tal restrição são: i) a limitação no exercício do poder jurisdicional, coibindo-se o arbítrio; ii) impedir que as partes sejam surpreendidas com decisões judiciais contrárias a seus interesses em face das quais não se oportunizou o exercício do contraditório e do direito de defesa; iii) a garantia de segurança e previsibilidade durante o trâmite processual e na prolação da decisão de mérito, assegurando-se que somente aquilo pedido pelas partes seja objeto da tutela jurisdicional.

A preocupação com a congruência entre o pedido formulado inicialmente e a sentença de mérito proferida é tão grande que o Código de Processo Civil eleva seu descumprimento à categoria de vício processual ${ }^{401}$, conforme redação do artigo 460: "É defeso ao juiz proferir sentença, a favor do autor, de natureza diversa da pedida, bem como condenar o réu em quantidade superior ou em objeto diverso do que lhe foi demandado" 402 .

Não obstante, da mesma forma como se deu em relação à análise do pedido inicial, não se pode levar tal princípio às últimas consequências, sob pena de negativa de proteção ao direito humano fundamental à previdência social.

Uma vez mais, a solução para o aparente impasse entre os direitos fundamentais à previdência social, à inafastabilidade do controle jurisdicional de ameaça ou lesão a direito e ao devido processo legal, por um lado, e os direitos fundamentais ao contraditório e ampla defesa, à inércia da jurisdição, à congruência entre pedido e sentença e princípio

\footnotetext{
${ }^{401}$ Não obstante viciadas, nem sempre será o caso de se decretar a nulidade das sentenças citra, ultra e extra petita, conforme escólio de Humberto Theodoro Júnior: "Já vimos que, em face dos arts. 128 e 460, o limite da sentença válida é o pedido, de sorte que é nula a sentença extra petita e a citra petita (cf. n $\mathrm{n}^{\mathrm{o}} \mathrm{s} 488 \mathrm{e}$ 493-b, retro). A sentença extra petita incide em nulidade porque soluciona causa diversa da que foi proposta através do pedido. (...) O defeito da sentença ultra petita, por seu turno, não é totalmente igual ao da extra petita. Aqui, o juiz decide o pedido, mas vai além dele, dando ao autor mais do que fora pleiteado (art. 460). A nulidade, então, é parcial, não indo além do excesso praticado, de sorte que, ao julgar o recurso da parte prejudicada, o tribunal não anulará todo o decisório, mas apenas decotará aquilo que ultrapassou o pedido. A sentença, enfim, é citra petita quando não examina todas as questões propostas pelas partes. (...) Mas o exame imperfeito ou incompleto de uma questão não induz nulidade da sentença, porque o tribunal tem o poder de, no julgamento da apelação, completar tal exame, em face do efeito devolutivo assegurado pelo art. $515, \S 1^{\circ}$. (...) A nulidade da sentença citra petita, portanto, pressupõe questão debatida e não solucionada pelo magistrado, entendida por questão o ponto de fato ou de direito sobre que dissentem os litigantes, e que, por seu conteúdo, seria capaz de, fora do contexto do processo, formar, por si só, uma lide autônoma. Só se anula, destarte, uma sentença em grau de recurso, pelo vício do julgamento citra petita, quando a matéria omitida pelo decisório de origem não esteja compreendida na devolução que o recurso de apelação faz operar para o conhecimento do Tribunal". THEODORO JÚNIOR, Humberto. op. cit., v. 1, p. 555-557. Para maior aprofundamento, confira-se: DINAMARCO, Candido Rangel. Instituições de direito processual civil, cit., v. 3, p. 292-294.

${ }^{402} \mathrm{Tal}$ redação restou aprimorada com o novo CPC (Lei n. 13.105/15), garantindo-se tal proteção em favor de ambas as partes processuais (autor e réu), conforme novo artigo 492: "É vedado ao juiz proferir decisão de natureza diversa da pedida, bem como condenar a parte em quantidade superior ou em objeto diverso do que lhe foi demandado".
} 
dispositivo, por outro lado, está na utilização do instituto da contingência social como chave interpretativa e de controle da sentença de mérito proferida.

Desse modo, o exercício de controle a ser feito diz respeito ao cotejo entre a contingência social comprovada durante a instrução processual e o benefício previdenciário concedido por meio da tutela jurisdicional de mérito. Caso o benefício concedido esteja inserido dentre aqueles previstos em lei para o atendimento da contingência social constatada, restará observado o princípio da congruência entre o pedido e a sentença $a^{403}$. Caso contrário, restará caracterizado o vício processual (sentença citra, extra ou ultra petita).

Também nesse sentido se firmou a jurisprudência do Superior Tribunal de Justiça, porém uma vez mais se utilizando de fundamento diverso, por meio da fixação da tese da análise flexível do pedido contido na petição inicial, admitindo-se a concessão de benefício diverso do expressamente postulado, conforme precedentes:

PROCESSUAL CIVIL. PREVIDENCIÁRIO. BENEFÍCIO MAIS
VANTAJOSO. JULGAMENTO EXTRA PETITA E REFORMATIO IN PEJUS
NÃO CONFIGURADOS.
1. Em relação à propositura com fulcro no art. 485, V, do CPC, a Ação
Rescisória por violação de literal disposição de lei só é cabível quando a
interpretação conferida pelo acórdão rescindendo for teratológica, revelando total
descompasso com a jurisprudência amplamente predominante à época do
julgado.
2. É firme o posicionamento do STJ, de que em matéria previdenciária deve
flexibilizar a análise do pedido contido na petição inicial, não se entendendo
como julgamento extra ou ultra petita a concessão de benefício diverso do
requerido na inicial. Precedentes: (AgRg no REsp 1.367.825/RS, Rel. Ministro
Humberto Martins, Segunda Turma, DJe 29/4/2013) e (AgRg no REsp
861.680/SP, Rel. Ministro Arnaldo Esteves Lima, Quinta Turma, DJe
17/11/2008).
3. Recurso Especial não provido. (REsp 1.499.784/RS, Rel. Ministro HERMAN BENJAMIN, 2 ${ }^{\mathrm{a}}$ TURMA, julgado em 3/2/2015, DJe 11/2/2015)

PROCESSUAL CIVIL E PREVIDENCIÁRIO. AGRAVO REGIMENTAL NO RECURSO ESPECIAL. BENEFÍCIO PREVIDENCIÁRIO. AÇÃO REQUERENDO CONCESSÃO DO BENEFÍCIO DE APOSENTADORIA POR TEMPO DE CONTRIBUIÇÃO. ACÓRDÃO QUE CONCEDE APOSENTADORIA POR IDADE. GARANTIA DE MELHOR BENEFÍCIO AO SEGURADO. INOCORRÊNCIA DE JULGAMENTO EXTRA PETITA. AGRAVO REGIMENTAL DO INSS DESPROVIDO.

\footnotetext{
403“De fato, a concepção de que em sentença em benefícios por incapacidade declarará o julgador, de acordo com a integralidade do material probatório coligido aos autos, o direito às prestações previstas em lei, independentemente do pedido específico formulado na exordial, está devidamente assentado". RUBIN, Fernando. op. cit., p. 133.
} 
1. O Direito Previdenciário não deverá ser interpretado como uma relação de Direito Civil ou Direito Administrativo no rigor dos termos, mas sim como fórmula ou tutela ao hipossuficiente, ao carecido, ao excluído. Este deve, também, ser um dos nortes da jurisdição previdenciária.

2. É firme a orientação desta Corte de que não constitui julgamento extra ou ultra petita a decisão que, verificando a inobservância dos pressupostos para concessão do benefício pleiteado na inicial, concede benefício diverso por entender preenchidos seus requisitos, tendo em vista a relevância da questão social que envolve a matéria. Precedentes.

3. Agravo Regimental do INSS desprovido.

(AgRg no REsp 1.320.249/RJ, Rel. Ministro NAPOLEÃO NUNES MAIA FILHO, $1^{\text {a }}$ TURMA, julgado em 07/11/2013, DJe 02/12/2013) (grifado)

Comentário crítico a ser feito diz respeito ao fato de não se tratar de análise flexível da petição inicial, mas de interpretação do regramento processual de acordo com os vetores constitucionais da efetividade do processo e da máxima proteção possível ao direito humano fundamental à previdência social.

Assim como se deu com relação à petição inicial, também o princípio da congruência deve ser entendido, nas lides previdenciárias, a partir de sua leitura sob a lupa da contingência social presente no caso concreto para, a partir daí, fixar-se o benefício previdenciário adequado à proteção da necessidade social comprovada.

No caso dos benefícios previdenciários por incapacidade laboral, não basta a comprovação da contingência social deflagradora da proteção estatal. A instrução probatória deverá ser abrangente a ponto de esclarecer em qual grau e alcance a mesma está presente, a fim de que seja concedida a prestação prevista em lei para aquela situação específica, com garantia da proteção integral ao direito humano fundamental.

Trata-se de nuance decorrente da fungibilidade ontológica existente entre os benefícios protetivos da incapacidade laboral, utilizada como mecanismo de controle para se assegurar proteção integral à contingência social constatada.

É mais um mecanismo de controle a atuar em prol da máxima eficácia possível do direito humano fundamental à previdência social, a exigir que a sentença conceda o benefício previdenciário mais adequado à proteção da contingência social, de modo que tal proteção seja integral.

Por isso mesmo andou bem o Superior Tribunal de Justiça ao não reconhecer qualquer ofensa ao princípio da congruência no caso de concessão de benefício por incapacidade mais completo do que aquele postulado na exordial, após restar comprovada 
a presença da contingência social da incapacidade laboral em grau e alcance mais elevados do que aqueles exigidos em lei para a concessão do benefício requerido na petição inicial, com respeito à fungibilidade, a conferir:

PREVIDENCIÁRIO. AGRAVO REGIMENTAL NO RECURSO ESPECIAL. PEDIDO DE CONCESSÃO DE AUXÍLIO-DOENÇA. OBTENÇÃO DO BENEFÍCIO APOSENTADORIA POR INVALIDEZ. JULGAMENTO EXTRA PETITA. NÃO CARACTERIZAÇÃO. PRECEDENTES DO STJ. AGRAVO REGIMENTAL A QUE SE NEGA PROVIMENTO.

1. O STJ tem entendimento consolidado de que, em matéria previdenciária, deve-se flexibilizar a análise do pedido contido na petição inicial, não entendendo como julgamento extra ou ultra petita a concessão de benefício diverso do requerido na inicial, desde que o autor preencha os requisitos legais do benefício deferido.

2. No caso, o Tribunal a quo, em sede de apelação, ao reconhecer a incapacidade definitiva da segurada para o desempenho de suas funções, reformou sentença concessiva do benefício auxílio-doença para conceder o benefício da aposentadoria por invalidez.

3. Agravo regimental a que se nega provimento.

(AgRg no REsp 1.305.049/RJ, Rel. Ministro MAURO CAMPBELL MARQUES, $2^{\text {a }}$ TURMA, julgado em 3/5/2012, DJe 8/5/2012)

PREVIDENCIÁRIO E PROCESSUAL CIVIL. CONCESSÃO DE BENEFÍCIO PREVIDENCIÁRIO DIVERSO DO PEDIDO. POSSIBILIDADE. PRECEDENTES.

1. É possível a concessão de benefício previdenciário diverso do pedido na inicial nos casos em que, do conjunto probatório dos autos, restar evidente o cumprimento dos requisitos necessários, aplicando-se, assim, o princípio da fungibilidade.

2. Agravo interno ao qual se nega provimento.

(AgRg no REsp 637.163/SP, Rel. Ministro CELSO LIMONGI (DESEMBARGADOR CONVOCADO DO TJ/SP), $6^{\mathrm{a}}$ TURMA, julgado em 17/9/2009, DJe 03/11/2009) (grifado)

\subsubsection{Direito à previdência social e atividade probatória ${ }^{404}$}

Mantendo a mesma linha de raciocínio desenvolvida nas duas questões anteriores, qual seja, a de se priorizar uma interpretação voltada à efetividade do direito humano fundamental à previdência social e do processo e ao amplo acesso à justiça, e tratando-se de questão ligada à forma de comprovação da alegada incapacidade laboral, como contingência social deflagradora do direito à percepção de uma das três prestações previdenciárias previstas em lei (aposentadoria por invalidez, auxílio-doença ou auxílioacidente), buscarei demonstrar a necessidade de se assegurar ampla oportunidade de

\footnotetext{
${ }^{404 ،} \mathrm{Na}$ dinâmica do processo e dos procedimentos, prova é um conjunto de atividades de verificação $e$ demonstração, mediante as quais se procura chegar à verdade quanto aos fatos relevantes para o julgamento". DINAMARCO, Candido Rangel. Instituições de direito processual civil, cit., v. 3, p. 43.
} 
produção probatória para a verificação da efetiva ocorrência (ou não) da contingência social, sob pena de violação ao direito humano fundamental social.

Nesse diapasão, é de se apontar que a própria doutrina processualista e jurisprudência pátrias têm temperado os rigores formais no tocante à iniciativa e momento da produção probatória no processo.

Assim é que, não obstante as garantias constitucionais processuais da inércia da jurisdição e dispositiva, tendentes à vedação de iniciativa processual por parte do magistrado, como parte imparcial - e que na questão probatória assumem o formato do princípio da liberdade das partes em sua produção -, restam assegurados alguns poderes instrutórios aos juízes, nos termos do artigo 130, do CPC: “Caberá ao juiz, de ofício ou a requerimento da parte, determinar as provas necessárias à instrução do processo, indeferindo as diligências inúteis ou meramente protelatórias" ${ }^{\prime 45}$.

Tal iniciativa probatória por parte dos magistrados tem por finalidades precípuas garantir $^{406}:$ i) a paridade efetiva de armas entre as partes litigantes, compensando eventuais hipossuficiências; ii) o contraditório e a ampla defesa ${ }^{407}$; iii) o interesse público, já que a atividade jurisdicional diz respeito a uma importante função do Estado, que é o monopólio da coerção legítima; iv) a entrega do bem da vida para quem de direito, com a pacificação social.

Também justifica a atribuição de poderes instrutórios ao magistrado a grande importância assumida pelo direito à prova no processo civil moderno, como corolário dos princípios constitucionais estruturantes do devido processo legal, do contraditório e da ampla defesa, voltados à garantia de um processo civil justo e équo, que entregue a tutela

\footnotetext{
${ }^{405}$ De acordo com o novo CPC (Lei n. 13.105/15), tal regime resta aperfeiçoado, da seguinte forma: “Caberá ao juiz, de ofício ou a requerimento da parte, determinar as provas necessárias ao julgamento do mérito. $\mathrm{O}$ juiz indeferirá, em decisão fundamentada, as diligências inúteis ou meramente protelatórias". (novo art. 370).

${ }^{406}$ Confira-se, a propósito: i) DINAMARCO, Candido Rangel. Instituições de direito processual civil, cit., v. 3, p. 51-57; ii) DIDIER JUNIOR, Fredie; BRAGA, Paula Sarno; OLIVEIRA, Rafael. Curso de direito processual civil, cit., v. 2, p. 20-26; iii) THEODORO JÚNIOR, Humberto. op. cit., v. 1, p. 460-461.

${ }^{407 ،} \mathrm{Na}$ Constituição, o direito à prova é inerência do conjunto de garantias do justo processo, que ela oferece ao enunciar os princípios do contraditório e ampla defesa, culminando por assegurar a própria observância destes quando garante a todos o due process of law (art. 5, incs. LIV e LV - supra, nn. 94 e 97). Pelo aspecto constitucional, direito à prova é a liberdade de acesso às fontes e meios segundo o disposto em lei e sem restrições que maculem ou descaracterizem o justo processo". DINAMARCO, Candido Rangel. Instituições de direito processual civil, cit., v. 3, p. 48-49.
} 
jurisdicional adequada a quem de direito, assegurando os direitos fundamentais materiais $^{408}$.

Em se tratando de direitos humanos fundamentais sociais, é de se acrescentar o argumento justificador da atividade probatória pelos magistrados atinente à busca da verdade real, de molde a proteger o direito material da parte processual mais fraca, hipossuficiente, reequilibrando-se a relação jurídica processual, com a redistribuição dos ônus e da própria atividade probatória. Evita-se, assim, a negativa do direito fundamental por razões meramente formais, de cunho processual ${ }^{409}$.

Como decorrência da importância do direito à prova no processo e dos poderes instrutórios do magistrado, voltada à efetividade do processo e à garantia dos direitos humanos fundamentais, tem-se a estruturação dos princípios: i) da aquisição da prova pelo processo, pelo qual a atividade probatória é voltada à instrução processual, e não ao benefício de uma das partes processuais ${ }^{410}$; ii) da liberdade das fontes de prova, pela qual

408“Direito à prova é o conjunto de oportunidades oferecidas à parte pela Constituição e pela lei, para que possa demonstrar no processo a veracidade do que afirmam em relação aos fatos relevantes para o julgamento. Ele é exercido mediante o emprego de fontes de prova legitimamente obtidas e a regular aplicação das técnicas representadas pelos meios de prova. A imensa importância da prova na experiência do processo erigiu o direito à prova em um dos mais respeitados postulados inerentes à garantia política do devido processo legal, a ponto de se constituir em um dos fundamentais pilares do sistema processual contemporâneo. Sem sua efetividade não seria efetiva a própria garantia constitucional do direito ao processo. O tema da prova é de particular importância na ciência processual 'não só pelo valor da reconstrução dos fatos na formação do provimento jurisdicional, mas sobretudo por constituir ponto de observação privilegiado para o estudo das íntimas e complexas relações entre o processo e as estruturas sociais' (Antonio Magalhães Gomes Filho)". DINAMARCO, Candido Rangel. Instituições de direito processual civil, cit., v. 3, p. 47.

409،"Extrai-se inegavelmente da $\mathrm{CF} / 88$, a máxima de que a prova é algo fundamental para o processo, que não é algo acessório, que não pode ser simplesmente indeferido pelo magistrado sem maiores repercussões. Se é bem verdade que há disposição expressa a respeito do macro princípio da 'efetividade', conforme preconiza o novel inciso LXXVIII do art. $5^{\circ}$, há dispositivos constitucionais - embora menos explícitos que se colocam mais propriamente a favor da prova, voltados ao macro princípio da 'segurança jurídica', no sentido de garantia de aproximação do juiz da verdade no caso concreto. Dentre os fundamentos constitucionais do direito prioritário à prova, podemos elencar: art. $5^{\circ}, \mathrm{XXXV}$ : acesso (adequado) ao Judiciário; art. $5^{\circ}$, LIV: devido processo legal (processo justo); art. $5^{\circ}$, LV: contraditório e ampla defesa (com os meios de prova inerentes); art. $5^{\circ}$, LVI: provas lícitas (processo que aceita número amplo de provas lícitas). Tais dispositivos - relevantíssimos dentro do contexto processo-constitucional - podem (devem) ser interpretados articuladamente a fim de que o procedimento judicial em Direito Social seja não só célere, mas também qualificado - o que, diante do nosso objeto de investigação, é obtido por meio da não limitação excessiva do direito de provar. Nesse diapasão, a doutrina especializada destaca que embora o direito à prova não seja absoluto (como nenhum direito pode desta forma ser concebido), deve ser reconhecido como prioritário para o sistema processual, não podendo ser indevidamente limitado, a ponto de seu exercício ser meramente residual”. RUBIN, Fernando. op. cit., p. 148-149. Para aprofundamento sobre a questão da busca da verdade material e sua importância nas lides previdenciárias, confira-se: i) TAVARES, Marcelo Leonardo. O devido processo legal previdenciário e as presunções de prova. In: TAVARES, Marcelo Leonardo et al. (Coords.). Direito processual previdenciário: temas atuais. Niterói: Ímpetus, 2009. p. 13-18; ii) SERAU JUNIOR, Marco Aurélio. op. cit., p. 220-231.

410“"A prova, uma vez produzida, desgarra-se daquele que a produziu e é incorporada ao processo - não podendo ser dele extraída ou desentranhada, salvo exceções ( $\S 1^{\circ}$ e $2^{\circ}$ do art. 1.215 do CPC). A prova adere ao processo, sendo irrelevante saber quem a trouxe. O que importa é a sua existência e, não, sua 
todos os meios de prova são idôneos à prova dos fatos alegados, desde que lícitos ${ }^{411}$; iii) da livre valoração motivada das provas pelo magistrado, sem existir hierarquia entre as mesmas $^{412}$.

Já no tocante ao momento da produção probatória, concentrado em nosso sistema processual em duas oportunidades bastante destacadas - após a decisão saneadora ${ }^{413}$ e na audiência de instrução e julgamento ${ }^{414}$ - de há muito resta consolidada a jurisprudência do Superior Tribunal de Justiça no sentido de que: i) a produção da prova documental pode ocorrer até a prolação da sentença de mérito, desde que observado o contraditório, nos termos do art. 398 , do $\mathrm{CPC}^{415}$; ii) o juiz não pode indeferir a produção de prova requerida pela parte no momento processual oportuno e utilizar como fundamento da sentença de improcedência exatamente o argumento da falta de provas ${ }^{416}$, iii) o depósito intempestivo dos quesitos não importa em preclusão da produção da prova pericial ${ }^{417}$; iv) a atividade probatória do juiz não se submete ao regime da preclusão processual ${ }^{418}$.

Trata-se de entendimentos voltados à mitigação de exigências formais em termos de prazos e procedimentos necessários ao exercício do direito à prova, cujas finalidades

proveniência (origem). Quando trazida aos autos, a prova sai da esfera de disposição daquele que a providenciou (parte, MP, terceiro ou juiz), tornando-se pública, comum e parte integrante do conjunto probatório, para favorecer ou desfavorecer quem quer que seja. Produzida pela parte pode servir até mesmo aos seus litisconsortes (o que se verá a seguir) ou ao seu adversário. Afinal, a prova não pertence à parte, mas ao processo. É produzida para o processo. Eis o teor da chamada aquisição processual ou comunhão da prova, por muitos designada como princípio probatório. (...) Assim, cabe ao juiz considerar e valorar todo o material probatório constante nos autos - 'tudo que está nos autos está também no universo a ser considerado pelo juiz' -, sem qualquer preocupação acerca da sua fonte ou origem, desde que lícita”. DIDIER JUNIOR, Fredie; BRAGA, Paula Sarno; OLIVEIRA, Rafael. Curso de direito processual civil, cit., v. 2, p. 26-27.

411“Todos os meios legais, bem como os moralmente legítimos, ainda que não especificados neste Código, são hábeis para provar a verdade dos fatos, em que se funda a ação ou a defesa" (art. 332, do CPC). O Novo CPC (Lei n. 13.105/15) aperfeiçoou a redação, para a seguinte forma: "As partes têm o direito de empregar todos os meios legais, bem como os moralmente legítimos, ainda que não especificados neste Código, para provar a verdade dos fatos em que se funda o pedido ou a defesa e influir eficazmente na convicção do juiz" (novo art. 369).

412“O juiz apreciará livremente a prova, atendendo aos fatos e circunstâncias constantes dos autos, ainda que não alegados pelas partes; mas deverá indicar, na sentença, os motivos que lhe formaram o convencimento" (art. 131, do CPC). Redação aperfeiçoada pelo Novo CPC (Lei n. 13.105/15), nos seguintes termos: "O juiz apreciará a prova constante dos autos, independentemente do sujeito que a tiver promovido, e indicará na decisão as razões da formação de seu convencimento" (novo art. 371).

${ }^{413}$ Art. 331, $\S 2^{\circ}$ e $3^{\circ}$, do CPC (no novo CPC - Lei n. 13.105/15 - art. 357, II).

${ }^{414}$ Arts. 451 e 452 do CPC (no novo CPC - Lei n. 13.105/15 - art. 361).

${ }^{415}$ REsp 1.159.937/RJ, Rel. Min. Og Fernandes, DJe 28/8/2014; REsp 888.467/SP, Rel. Min. Luis Felipe Salomão, DJe 6/10/2011.

${ }^{416} \mathrm{AgRg}$ no REsp 1.454.129/BA, Rel. Min. Benedito Gonçalves, DJe 4/8/2015; AgRg no REsp 1.415.970/MT, Rel. Min. Nancy Andrighi, DJe 15/8/2014.

${ }^{417}$ AgRg no AREsp 520.640/SC, Rel. Min. Moura Ribeiro, DJe 26/5/2015; REsp 1.109.357/RJ, Rel. Min. Nancy Andrighi, DJe 1/7/2010.

${ }^{418}$ AgRg no AREsp 536.364/SC, Rel. Min. Raul Araújo, DJe 3/9/2015; AgRg no AREsp 668.463/GO, Rel. Min. Maria Isabel Gallotti, DJe 20/4/2015; REsp 896.072/DF, Rel. Min. Francisco Falcão, DJe 5/5/2008. 
são a efetivação do processo dentro do seu escopo de pacificação social e priorização da garantia do direito material.

Ora, se assim o é na processualística moderna, com muito mais razão deverá ser nas lides previdenciárias, voltadas à efetivação do direito humano fundamental à previdência social.

Logo, a atividade de produção probatória deverá ser garantida e incentivada nas lides previdenciárias em geral, mediante ampla liberdade probatória pelas partes, utilização dos poderes instrutórios pelo juiz e mitigação dos prazos e exigências formais no tocante à produção probatória. Tudo com o escopo da busca da verdade real, utilizando-se o processo como instrumento de garantia e efetivação dos direitos humanos fundamentais ${ }^{419}$.

Especificamente no tocante à tutela jurisdicional da contingência social da incapacidade laboral decorrente de doença e/ou invalidez e seus respectivos benefícios previdenciários, há de ser garantida, invariavelmente, a produção da prova pericial na via judicial, mesmo que, para tanto, seja necessária a utilização dos poderes instrutórios pelo magistrado ${ }^{420}$.

Não cabe seu indeferimento ao argumento da realização de prova similar na via administrativa, por meio de exame médico a cargo de perito do INSS, em razão da impessoalidade da Administração Pública (princípio constitucional expresso no seu art. 37) e dos predicados da presunção de legalidade e de legitimidade dos atos administrativos ${ }^{421}$, uma vez que se trata de prova produzida unilateralmente, de forma parcial, não se

\footnotetext{
419“'Assim, o processo deve estar adequado à tutela efetiva dos direitos fundamentais (dimensão subjetiva) e, além disso, ele próprio deve ser estruturado de acordo com os direitos fundamentais (dimensão objetiva). No primeiro caso, as regras processuais devem ser criadas de maneira adequada à tutela dos direitos fundamentais (daí que, por exemplo, o $\S 5^{\circ}$ do art. 461 do CPC permite ao magistrado a determinação de qualquer medida executiva para efetivar a sua decisão, escolhendo-a à luz das peculiaridades do caso concreto). No segundo caso, o legislador deve criar regras processuais adequadas aos direitos fundamentais, aqui encarados como normas, respeitando, por exemplo, a igualdade das partes e o contraditório". DIDIER JUNIOR, Fredie. Curso de direito processual civil, cit., v. 1, p. 41.

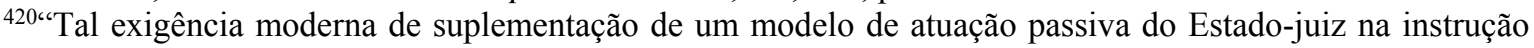
processual orienta então o julgador a buscar a verdade independente da preclusão para as partes em matéria de prova - valendo-se de todos os meios probatórios lícitos e legítimos, típicos ou atípicos". RUBIN, Fernando. op. cit., p. 143.

421“'Quanto ao espaço de produção da prova pericial, já se decidiu que sendo insuficiente a prova pericial produzida pela autarquia previdenciária, imprescindível é a realização da prova pericial em juízo, sob pena de cerceamento de defesa e consequente anulação da decisão de primeiro grau". SERAU JUNIOR, Marco Aurélio. op. cit., p. 267.
} 
revestindo das garantias constitucionais do devido processo legal, do contraditório e da ampla defesa ${ }^{422}$, como direitos fundamentais garantidos aos litigantes em geral ${ }^{423}$.

Mesmo que assim não o fosse, a imperiosidade da produção de tal prova na via judicial resta garantida pelo direito humano fundamental constitucional à previdência social em razão da contingência social da incapacidade laboral (art. 201, I, da Constituição) e pelo princípio da inafastabilidade do controle jurisdicional de ameaça ou lesão a direito (art. 5 XXXV, da Constituição) $)^{424}$.

Ademais, reveste-se de extrema importância o princípio do livre convencimento motivado do magistrado nesta seara, na medida em que "o juiz não está adstrito ao laudo pericial, podendo formar a sua convicção com outros elementos ou fatos provados nos autos" 425.

Evidente, pois a perícia médica judicial, não obstante sua enorme relevância para o deslinde das demandas envolvendo benefícios por incapacidade laboral, não passa de um dos elementos de prova colhidos ao longo da instrução processual, portanto, esclarecedora de fatos relacionados à lide, mas nem por isso possuindo o condão de vincular a decisão de mérito a ser proferida.

${ }^{422}$ Confira-se, nesse exato sentido, importante precedente do STJ: REsp 822.207/RS, Rel. Min. Humberto Gomes de Barros, DJ 18/12/2006.

423“"Nesse ponto, vale dizer que nossa legislação previdenciária exige a comprovação da invalidez, requisito indispensável à concessão de alguns benefícios previdenciários, nos seguintes casos: aposentadoria por invalidez; restabelecimento de aposentadoria por invalidez; auxílio-acidente; auxílio-doença; restabelecimento de auxílio-doença; renda mensal vitalícia ou benefício de assistência social; conversão do auxílio-doença em aposentadoria por invalidez; e, finalmente, concessão de pensão por morte de segurado para filha maior inválida. Tal prova ocorre, indubitavelmente, pela via da realização da prova pericial desenvolvida por profissional da área médica. O cabimento da prova pericial, nos casos citados, decorre da 'própria natureza da demanda envolver a necessidade de apuração de fatos sob ótica de critérios médicocientíficos, em especial da definição do real quadro (...) do autor para fins previdenciários, evidencia-se que o magistrado carece de conhecimento e juízo técnicos para, por si só, qualificar e valorar apriorística e peremptoriamente dita realidade fática, razão por que revela-se imprescindível a produção de prova pericial devidamente requerida pela parte'. O desatendimento dessa imposição é tido como 'frontal lesão à garantia constitucional do devido processo legal procedimental (procedural due process of law), por violação do primado do direito fundamental ao pleno contraditório, ínsito no inc. LV do art. $5^{\circ}$ da CF, conceito que transcende ao mero direito de resposta, constituindo-se, em verdade, a garantia conferida às partes de plena dedução de todo instrumental contido no ordenamento jurídico processual'. Sua consequência é a verificação do cerceamento de defesa, que acarreta nulidade processual, cujos termos serão mais bem apreciados adiante". SERAU JUNIOR, Marco Aurélio. op. cit., p. 261-263.

424“'Da mesma forma, não se aceita a tese de que a perícia médica idônea à comprovação da incapacidade laboral para fins previdenciários seja privativa do INSS. Tal alegação 'é desprovida de amparo legal, já que a decisão administrativa não impede que a questão venha a ser também apreciada judicialmente, a teor do Princípio da Inafastabilidade do Controle Jurisdicional, estabelecido na Constituição Federal, em seu art. $5^{\circ}$, XXXV"”. Id. Ibid., p. 268.

${ }^{425}$ Art. 436, do CPC, mantido, em sua essência, pelo novo CPC (Lei n. 13.105/15), conforme novo art. 479. 
Outrossim, é certo que a contingência social deflagradora do direito à prestação previdenciária, no caso em tela, é a incapacidade laboral - não a mera constatação de doença e/ou invalidez -, conceito jurídico que exige o cotejo dos males com a atividade profissional desempenhada pelo segurado para aferição da afetação de sua capacidade laboral (e em que grau e alcance), a demandar uma análise conjunta e sistemática dos elementos de prova trazidos ao processo. Há que se cotejar a prova pericial, essencial para a verificação dos aspectos relacionados aos males (doença e/ou lesões), com as provas documentais e orais produzidas no tocante à prova da atividade profissional e funções exercidas pelo segurado.

Tal é o entendimento sufragado pelo Superior Tribunal de Justiça, conforme precedentes:

PREVIDENCIÁRIO. AUXÍLIO-DOENÇA OU APOSENTADORIA POR INVALIDEZ. ACÓRDÃO QUE, À LUZ DAS PROVAS DOS AUTOS, CONCLUIU PELA INEXISTÊNCIA DOS SEUS REQUISITOS. PROVA PERICIAL. LIVRE CONVENCIMENTO DO JULGADOR. REVISÃO DA CONCLUSÃO ADOTADA NA ORIGEM. IMPOSSIBILIDADE. SÚMULA 7/STJ. PRECEDENTES. AGRAVO REGIMENTAL IMPROVIDO.

I. De acordo com os precedentes desta Corte a respeito da matéria, "o magistrado não está vinculado aos laudos médicos oficiais, podendo decidir o feito de acordo com outras provas juntadas aos autos, sendo livre seu convencimento" (STJ, AgRg no AREsp 371.436/MS, Rel. Ministro SÉRGIO KUKINA, PRIMEIRA TURMA, DJe de 11/04/2014).

II. Conforme entendimento reiterado deste Superior Tribunal de Justiça, "a análise da preexistência ou não de patologia à época da filiação do agravante ao RGPS e/ou a análise da progressão ou agravamento da patologia de que o agravante é portador implica, necessariamente, o reexame do quadro fáticoprobatório delineado nas instâncias ordinárias, providência esta vedada em sede de recurso especial, nos termos da Súmula 7/STJ" (STJ, AgRg no AREsp 402.361/SP, Rel. Ministro MAURO CAMPBELL MARQUES, SEGUNDA TURMA, DJe de 04/12/2013), tal como se pretende, in casu.

III. Agravo Regimental improvido.

(AgRg no AREsp 616.970/SP, Rel. Ministra ASSUSETE MAGALHÃES, $2^{\mathrm{a}}$ TURMA, julgado em 8/9/2015, DJe 18/9/2015)

PREVIDENCIÁRIO. APOSENTADORIA POR INVALIDEZ. REEXAME DOS REQUISITOS PARA CONCESSÃO DO BENEFÍCIO. REEXAME DO CONJUNTO FÁTICO-PROBATÓRIO DOS AUTOS. SÚMULA 7/STJ. CONSIDERAÇÃO DOS ASPECTOS SOCIOECONÔMICOS, PROFISSIONAIS E CULTURAIS DO SEGURADO. DESNECESSIDADE DE VINCULAÇÃO DO MAGISTRADO À PROVA PERICIAL.

I - A inversão do julgado, na espécie, demandaria o reexame do conjunto fáticoprobatório dos autos, razão pela qual incide o enunciado da Súmula 7/STJ.

III - Esta Corte Superior firmou entendimento no sentido de que a concessão da aposentadoria por invalidez deve considerar, além dos elementos previstos no art. 42 da Lei n. 8.213/91, os aspectos socioeconômicos, profissionais e culturais do segurado, ainda que o laudo pericial apenas tenha concluído pela sua incapacidade parcial para o trabalho (AgRg no AREsp 574.421/SP, Rel. Ministro Humberto Martins, Segunda Turma, DJe 14/11/2014).

III - Agravo regimental improvido. 
(AgRg no AREsp 35.668/SP, Rel. Ministro NEFI CORDEIRO, 6 ${ }^{\mathrm{a}}$ TURMA, julgado em 5/2/2015, DJe 20/2/2015) (grifado)

Por fim, conclusão inarredável do exposto é aquela no sentido de que o perito médico judicial deverá avaliar as reais condições de saúde do segurado quando da realização da perícia, mediante análise de exames médicos e físicos, sem qualquer restrição relacionada aos fatos narrados na exordial, sob pena de negativa de proteção e efetividade do direito humano fundamental social.

Uma vez mais resta salientar a necessidade de interpretação dos institutos processuais nas lides previdenciárias à luz da contingência social alegada na petição inicial. É a contingência social o elemento controlador e limitador do âmbito da lide em cada caso concreto, não havendo que se falar em limitações outras.

Não há que se falar em qualquer violação aos princípios processuais da inércia da jurisdição, do contraditório e ampla defesa, dispositivo e da congruência entre pedido e sentença, uma vez que o INSS, como parte ré, já teve desde a citação ciência inequívoca acerca da contingência social arrolada como objeto do processo judicial, bem como contato prévio, no âmbito administrativo, com os fatos narrados, aliás, negando o direito à prestação previdenciária, além do que será devidamente intimado acerca da produção da prova pericial, bem como das demais provas trazidas ao processo, podendo acompanhá-las, influenciá-las e impugná-las ${ }^{426}$.

Por tais razões, discordo do entendimento cristalizado em sede do Superior Tribunal de Justiça, no sentido de vedar a concessão de benefício previdenciário por incapacidade quando comprovada mediante o reconhecimento de fatos diversos daqueles arrolados na petição inicial, enxergando em tal vedação violação ao direito humano fundamental social, bem como ao caráter de fungibilidade, ontológico e material, de que se revestem os benefícios previdenciários por incapacidade ${ }^{427}$.

\footnotetext{
${ }^{426}$ Para maior aprofundamento acerca da dinâmica da produção da prova pericial, confira-se: A) no âmbito processual: i) DINAMARCO, Candido Rangel. Instituições de direito processual civil, cit., v. 3, p. 585597; ii) DIDIER JUNIOR, Fredie; BRAGA, Paula Sarno; OLIVEIRA, Rafael. Curso de direito processual civil, cit., v. 2, p. 227-260; B) no âmbito previdenciário: i) SAVARIS, José Antonio. op. cit., p. 221-237; ii) SERAU JUNIOR, Marco Aurélio. op. cit., p. 261-274; iii) AMADO, Frederico. op. cit., p. 951-959.

${ }^{427}$ Trata-se do AgRg no REsp 1.019.779/MG, Rel. Min. Nefi Cordeiro, DJe 3/2/2015, transcrito e já criticado no capítulo 10 , ao qual remeto o leitor.
} 


\section{CONSIDERAÇÕES FINAIS DE ORDEM PROCESSUAL}

Quero aproveitar este capítulo para trazer uma última questão fulcral dentro da linha de raciocínio desenvolvida ao longo deste trabalho.

Trata-se de exigência decorrente da adoção da seguinte conclusão lançada por Virgílio Afonso da Silva em sua obra "Direitos Fundamentais: conteúdo essencial, restrições e eficácia": ao se adotar as teorias do suporte fático amplo e externa em termos de restringibilidade dos direitos humanos fundamentais enquanto princípios jurídicos, impõe-se um ônus argumentativo à autoridade competente em termos de negativa de implementação do direito humano fundamental no caso concreto ${ }^{428}$.

A meu ver, tal conclusão também se aplica às lides judiciais concessivas de benefícios previdenciários, exigindo do julgador maior rigor em termos de fundamentação da negativa de condenação do Estado na prestação do benefício postulado.

Razão disso é que estou tratando de negativa de proteção jurisdicional a direito humano fundamental social, o que somente poderá ocorrer em duas situações básicas: i) ausência de comprovação da ocorrência de contingência social deflagradora do direito fundamental à previdência social; ii) existência de princípios constitucionais aparentemente colidentes e que, no caso concreto, deverão prevalecer sobre o direito humano fundamental social, como solução decorrente da utilização dos métodos da proporcionalidade ou do sopesamento na análise dos princípios jurídicos envolvidos.

Quanto ao primeiro caso, conforme já demonstrado no capítulo anterior, deverá ser assegurada a máxima efetividade possível ao direito probatório ${ }^{429}$, com a decorrente mitigação na interpretação das demais exigências processuais, quais sejam: as de certeza e determinação do pedido inicial; de congruência entre pedido e sentença; da inércia da jurisdição e do princípio dispositivo, bem como aquelas relacionadas ao regime processual das preclusões, a fim de que a instrução processual seja a mais ampla e profunda, buscando-se a verdade real, com a máxima proteção possível ao direito humano

\footnotetext{
${ }^{428}$ Remeto o leitor ao capítulo 4 desta obra, nota de rodapé 169 , que faz menção à transcrição da passagem da obra de Virgílio Afonso da Silva ora retomada.

${ }^{429}$ Confira-se, nesta mesma linha: SERAU JUNIOR, Marco Aurélio. op. cit., p. 220-231.
} 
fundamental social, impedindo-se a negativa do direito material por questões meramente formais, de ordem processual.

Quanto ao segundo caso, deverão ser asseguradas, na medida do possível, todas as condições possíveis e necessárias à solução de mérito do processo, com a entrega da tutela jurisdicional em favor da parte, bem como à execução da tutela jurisdicional favorável, com a utilização de todos os meios e poderes processuais conferidos aos juízes para se assegurar a entrega do bem da vida concedido em favor do segurado.

Ademais, a negativa do direito material postulado deverá se revestir de fundamentação sólida, pormenorizada e individualizada, com a menção expressa às razões de fato e de direito que levaram à improcedência do pedido; além do que o magistrado gozará de maior autonomia e liberdade para exercer o controle difuso de constitucionalidade de leis e atos normativos infralegais ${ }^{430}$ que sirvam de óbice à concessão da proteção previdenciária pelo Estado.

É verdade que o dever de fundamentação das decisões judiciais constitui garantia e controle dos atos jurisdicionais praticados pelo Estado-juiz em face dos cidadãos, configurando verdadeiro direito humano fundamental individual ${ }^{431}$ à luz do artigo 93, IX, da Constituição ${ }^{432}$. Logo, o dever de fundamentação se aplica de forma plena às decisões judiciais, inclusive, àquelas negativas da prestação previdenciária requerida ${ }^{433}$.

430“"Vale lembrar, ainda, que é também na fundamentação que o órgão jurisdicional deverá deliberar sobre a constitucionalidade ou inconstitucionalidade de ato normativo, acaso a questão seja suscitada pelas partes ou mesmo analisada de ofício - o que é possível, por se tratar, igualmente, de questão de direito. Como cediço, no nosso sistema, qualquer magistrado pode conhecer da questão relativa à inconstitucionalidade de um ato normativo, mas a solução que der a essa questão somente valerá, a princípio, para aquele caso concreto, não se estendendo às pessoas que não participaram do processo". DIDIER JUNIOR, Fredie; BRAGA, Paula Sarno; OLIVEIRA, Rafael. Curso de direito processual civil, cit., v. 2, p. 296.

431،A garantia da motivação das decisões judiciais possui natureza de direito fundamental do jurisdicionado. A própria Constituição Federal, em seu art. 93, IX, estabelece que toda decisão judicial deve ser motivada e, fugindo um pouco à sua linha, normalmente principiológica e descritiva, prescreve norma sancionadora, cominando pena de nulidade para as decisões judiciais desmotivadas. Ainda, porém, que não houvesse expressa disposição constitucional nesse sentido, a regra da motivação não deixaria de ser um direito fundamental do jurisdicionado, eis que é consectário da garantia do devido processo legal e manifestação do Estado de Direito".

432، "Todos os julgamentos dos órgãos do Poder Judiciário serão públicos, e fundamentadas todas as decisões, sob pena de nulidade, podendo a lei limitar a presença, em determinados atos, às próprias partes e a seus advogados, ou somente a estes, em casos nos quais a preservação do direito à intimidade do interessado no sigilo não prejudique o interesse público à informação". DIDIER JUNIOR, Fredie; BRAGA, Paula Sarno; OLIVEIRA, Rafael. Curso de direito processual civil, cit., v. 2, p. 291.

${ }^{433}$ Confira-se visão processualista abalizada sobre o dever de fundamentação das decisões judiciais: "Para conferir racionalismo e legitimidade a toda essa independência de que goza o juiz, é preciso exigir que preste contas do que decide, explicitando as razões pelas quais chega às conclusões adotadas. Daí a exigência de motivação, ditada também na lei ordinária ao estabelecer a tríplice estrutura das sentenças (relatório-motivação-dispositivo: CPC, art. 458). Disposição como essa existe também com relação à sentença arbitral (art. 26 LA). O art. 131 do Código de Processo Civil, ao fixar a regra do livre 
O que defendo aqui é uma espécie de "inversão" no método de raciocínio a ser desenvolvido quando da prolação da sentença de mérito nas lides previdenciárias concessivas de benefício: ao invés de se partir do "status quo ante", que é a negativa administrativa do benefício, exigindo-se, a partir daí, a comprovação de todos os elementos necessários à comprovação do direito postulado, com exigências maiores de fundamentação para o decreto de procedência do pedido em comparação com o de improcedência, deve-se partir de uma postura protetiva do direito humano fundamental à previdência social, para, a partir daí, se perquirir acerca da ocorrência de razões fáticas e jurídicas fundamentadoras da negativa de proteção ao direito postulado, logo, com maiores exigências argumentativas em termos de indeferimento da pretensão, se comparadas às de seu deferimento.

Veja que tal conclusão, além de ser totalmente coerente com a noção impositiva de ônus argumentativo à autoridade competente para negar o direito humano fundamental no caso concreto, também gera alguns reflexos sobre a própria atividade processual probatória, notadamente em termos de relativização da regra processual de distribuição do ônus da prova.

Interessante notar que o novo Código de Processo Civil (Lei n. 13.105/15) traz algumas evoluções neste exato sentido, se comparado ao regramento atual, a conferir:

\footnotetext{
“Art. 489. São elementos essenciais da sentença:

I - o relatório, que conterá os nomes das partes, a identificação do caso, com a suma do pedido e da contestação, e o registro das principais ocorrências havidas no andamento do processo;
}

\footnotetext{
convencimento, manda que este se forme com base nos elementos de prova existentes nos autos, o que levou a doutrina a definir a regra do livre convencimento motivado (José Rogério Cruz e Tucci). Motivando adequadamente, o juiz presta contas de sua conduta às próprias partes, aos órgãos superiores da Magistratura e à opinião pública, para os devidos controles e particularmente para aquele que se faz em via recursal. Para cumprir seu objetivo político e atender às exigências da Constituição e da lei, a motivação deve ser tal que traga ao leitor a sensação de que o juiz decidiu de determinado modo porque assim impunham os fundamentos adotados, mas decidiria diferentemente se tivesse adotado outros fundamentos seja no exame da prova, seja na interpretação do sistema jurídico. Tal é a exigência de coerência na motivação, sem a qual ela é irregular e a sentença, nula. Exige-se também que a motivação seja completa, sem omitir pontos cuja solução pudesse conduzir o juiz a concluir diferentemente. Sempre que a sentença seja repartida em capítulos, cada um deles consistindo no julgamento de uma pretensão, todos eles devem ser precedidos de uma motivação que justifique a conclusão assumida pelo juiz (infra, nn. 890-891). A exigência de inteireza da motivação (Michele Taruffo) não chega ao ponto de mandar que o juiz se manifeste especificamente sobre todos os pontos, mais relevantes ou menos, ou mesmo sem relevância alguma ou quase sem relevância, que as partes hajam suscitado no processo. O essencial é motivar no tocante aos pontos relevantes e essenciais, de modo que a motivação lançada em sentença mostre que o juiz tomou determinada decisão porque assumiu determinados fundamentos com que esta guarda coerência. A regra de equilíbrio é esta: motiva-se no essencial e relevante, dispensa-se relativamente a motivação no periférico e circunstancial". DINAMARCO, Candido Rangel. Instituições de direito processual civil, cit., v. 1, p. 242-244. Confira-se, outrossim: DIDIER JUNIOR, Fredie; BRAGA, Paula Sarno; OLIVEIRA, Rafael. Curso de direito processual civil, cit., v. 2, p. 290-297.
} 
II - os fundamentos, em que o juiz analisará as questões de fato e de direito;

III - o dispositivo, em que o juiz resolverá as questões principais que as partes lhe submeterem.

§ 10 Não se considera fundamentada qualquer decisão judicial, seja ela interlocutória, sentença ou acórdão, que:

I - se limitar à indicação, à reprodução ou à paráfrase de ato normativo, sem explicar sua relação com a causa ou a questão decidida;

II - empregar conceitos jurídicos indeterminados, sem explicar o motivo concreto de sua incidência no caso;

III - invocar motivos que se prestariam a justificar qualquer outra decisão;

IV - não enfrentar todos os argumentos deduzidos no processo capazes de, em tese, infirmar a conclusão adotada pelo julgador;

V - se limitar a invocar precedente ou enunciado de súmula, sem identificar seus fundamentos determinantes nem demonstrar que o caso sob julgamento se ajusta àqueles fundamentos;

VI - deixar de seguir enunciado de súmula, jurisprudência ou precedente invocado pela parte, sem demonstrar a existência de distinção no caso em julgamento ou a superação do entendimento.

§ 20 No caso de colisão entre normas, o juiz deve justificar o objeto e os critérios gerais da ponderação efetuada, enunciando as razões que autorizam a interferência na norma afastada e as premissas fáticas que fundamentam a conclusão.

§ 30 A decisão judicial deve ser interpretada a partir da conjugação de todos os seus elementos e em conformidade com o princípio da boa-fé". (grifado)

“Art. 373. O ônus da prova incumbe:

I - ao autor, quanto ao fato constitutivo de seu direito;

II - ao réu, quanto à existência de fato impeditivo, modificativo ou extintivo do direito do autor.

$\S 1$ 1 - Nos casos previstos em lei ou diante de peculiaridades da causa relacionadas à impossibilidade ou à excessiva dificuldade de cumprir o encargo nos termos do caput ou à maior facilidade de obtenção da prova do fato contrário, poderá o juiz atribuir o ônus da prova de modo diverso, desde que o faça por decisão fundamentada, caso em que deverá dar à parte a oportunidade de se desincumbir do ônus que lhe foi atribuído.

$\S 2$ 20 A decisão prevista no $\S 1$ o deste artigo não pode gerar situação em que a desincumbência do encargo pela parte seja impossível ou excessivamente difícil.

§ 3o A distribuição diversa do ônus da prova também pode ocorrer por convenção das partes, salvo quando:

I - recair sobre direito indisponível da parte;

II - tornar excessivamente difícil a uma parte o exercício do direito.

$\S 4^{\circ}$ A convenção de que trata o $\S 3^{\circ}$ pode ser celebrada antes ou durante o processo". (grifado)

Duas conclusões surgem inarredáveis de tais dispositivos:

I) $\mathrm{O}$ novo $\mathrm{CPC}$, em vez de se limitar a reproduzir a fórmula genérica do vigente art. 458, II ("os fundamentos, em que o juiz analisará as questões de fato e de direito"), passa a 
traçar alguns limites e controles objetivos ao dever de fundamentação por parte dos juízes, o que está de acordo com a ideia aqui defendida, exatamente a de impor um ônus argumentativo qualificado no caso das ações previdenciárias concessivas de proteção estatal em face da ocorrência de contingências sociais protegidas.

II) O novo $\mathrm{CPC}$, não obstante mantenha como regra o regime estático de distribuição do ônus probatório ${ }^{434}$ (art. 373, I e II), passa a autorizar expressamente a adoção, pelo magistrado $\left(\S \S s 1^{\circ}\right.$ e $2^{\circ}$ ) ou pelas próprias partes $\left(\S 3^{\circ}\right)$, do regime de distribuição dinâmica do ônus probatório ${ }^{435}$, o que se encaixa perfeitamente nas lides previdenciárias concessivas de benefício, em razão da posição claramente hipossuficiente assumida pelos segurados em termos processuais, já que os elementos de prova mais decisivos se encontram de posse do INSS, em face do qual tramitou previamente o requerimento administrativo voltado à obtenção da mesma proteção agora buscada pela via judicial.

Defendo, assim, com base no ônus argumentativo qualificado imposto ao magistrado para negar a proteção previdenciária postulada como direito humano fundamental social, a necessidade de se garantir o direito à ampla produção probatória pelas partes e pelo próprio magistrado, bem como a utilização da técnica da distribuição dinâmica do ônus probatório nas lides concessivas de benefício previdenciário, assegurando-se a busca da verdade real, rechaçando-se a utilização de critérios

\footnotetext{
${ }^{434}$ Trata-se da manutenção, via de regra, do regime atualmente vigente previsto no artigo 333, do CPC, que não mais atende, de forma satisfatória, a todos os tipos de demandas judiciais, em razão da grande variedade dos direitos materiais postulados em juízo. Realidade muito bem observada nos seguintes termos: "Com isso, adotou o nosso CPC uma concepção estática do ônus da prova, que é distribuído a priori, sem a observância das peculiaridades do caso concreto. Mas esse regramento tem-se revelado insatisfatório e artificial, por desprezar as especificidades do direito material em jogo e a realidade concretamente vivida, de modo que vem ganhando força a teoria da distribuição dinâmica do ônus da prova, logo mais examinada". DIDIER JUNIOR, Fredie; BRAGA, Paula Sarno; OLIVEIRA, Rafael. Curso de direito processual civil, cit., v. 2 , p. 82 .

435“Parece-nos que a concepção mais acertada sobre a distribuição do ônus da prova é essa última: a distribuição dinâmica do ônus da prova, segundo a qual a prova incumbe a quem tem melhores condições de produzi-la, à luz das circunstâncias do caso concreto. Em outras palavras: prova quem pode. Esse posicionamento justifica-se nos princípios da adaptabilidade do procedimento às peculiaridades do caso concreto, da cooperação e da igualdade, todos examinados no volume 1 deste Curso. (...) Enfim, de acordo com essa teoria: i) o encargo não deve ser repartido prévia e abstratamente, mas, sim, casuisticamente; ii) sua distribuição não pode ser estática e inflexível, mas, sim, dinâmica; iii) pouco importa, na sua subdivisão, a posição assumida pela parte na causa (se autor ou réu); iv) não é relevante a natureza do fato probando - se constitutivo, modificativo, impeditivo ou extintivo do direito - ou o interesse em prová-lo, mas, sim, quem tem mais possibilidades de fazer a prova". Id. Ibid., v. 2, p. 96-97. Para maior aprofundamento, confiram-se p. 95-102.
} 
interpretativos outros, como a mera inversão do ônus probatório ou a adoção do princípio do in dubio pro misero ${ }^{436}$.

A justificativa para se rechaçar tais técnicas está, a meu ver, no fato de que a sua utilização leva à perda do necessário equilíbrio processual real, agora em desfavor do Estado-administração, violando-se as garantias constitucionais processuais do devido processo legal, do contraditório e da ampla defesa, mediante a imposição de pesadíssimos ônus e deveres processuais - quase que invencíveis - para a parte ré da relação jurídica processual previdenciária, notadamente na seara probatória ${ }^{437}$, com o desvirtuamento das finalidades do processo, quais sejam: i) pacificação social; ii) garantia da tutela jurisdicional meritória a quem de direito.

${ }^{436}$ Para uma defesa na utilização da técnica da inversão do ônus da prova e do princípio do in dubio pro misero - contrariamente, pois, ao aqui defendido -, confira-se: RUBIN, Fernando. op. cit., p. 148-149.

${ }^{437}$ Trata-se da vedada probatio diabolica, entendida como sendo "aquela que é impossível, senão muito difícil, de ser produzida". DIDIER JUNIOR, Fredie; BRAGA, Paula Sarno; OLIVEIRA, Rafael. Curso de direito processual civil, cit., v. 2, p. 92. Para maior aprofundamento, confira-se p. 92-94. 


\section{CONCLUSÃO}

Conforme fiz questão de advertir na introdução, o objeto de estudo deste trabalho é bastante amplo, ao abarcar desde os fundamentos filosóficos dos direitos humanos fundamentais como verdadeiras conquistas civilizatórias e pilares evolutivos do ser humano, a partir da linha da Teoria Crítica, passando por sua evolução histórica e como tal influenciou e se imbricou com o movimento constitucionalista.

A partir de tal análise, foi possível evidenciar que, atualmente, os direitos humanos fundamentais foram alçados à categoria de pilares dos ordenamentos jurídicos estatais, ganhando uma série de instrumentos garantidores de sua especial e elevada posição dentro das atuais ordens constitucionais espalhadas pelo mundo, como reflexo da atual vertente neoconstitucionalista/concretista do direito constitucional enquanto teoria jurídica.

Por evidente que tais modificações levaram a um incremento nos níveis de abrangência e de proteção de tais direitos, porém ainda remanescem grandes resistências e celeumas doutrinárias acerca do assunto, razão pela qual envidei grandes esforços no sentido de desconstituir os principais óbices à garantia e eficácia dos direitos humanos fundamentais como verdadeiros direitos subjetivos, judicializáveis, tendentes à universalização em termos de proteção e cobertura, com pesados ônus ao Estado em termos de sua efetivação (concretização).

De tais análises surgiram os principais contornos de um regime jurídico próprio e único, de envergadura constitucional, altamente protetivo dos direitos humanos fundamentais, perfeitamente aplicável ao direito humano fundamental à previdência social.

Foi a partir daí que se possibilitou o desenvolvimento de uma análise do direito humano fundamental à previdência social a partir das suas disposições constitucionais garantidoras, com o corolário da necessária análise a partir das contingências sociais prescritas pelo constituinte, e não a partir das prestações previstas em lei.

Tal viragem conceitual foi fundamental na análise dos demais temas relacionados à previdência social como direito humano fundamental social: a unificação do elemento de discrímen permitiu uma análise sistemática e teleológica do sistema de proteção estatal previdenciário, entendido inequivocamente como um regime jurídico único, altamente protetivo, tendente à universalização em termos de cobertura. 
Não sem razão algumas das conclusões apresentadas em cada capítulo, ao tratar de temas palpitantes dentro do espectro dos benefícios previdenciários por incapacidade, divergem daquelas mais comumente apresentadas pela doutrina e pela jurisprudência pátrias.

Sucede que, com todo o respeito, as divergências apresentadas são voltadas a uma crítica construtiva da forma de análise até hoje empreendida sobre tais benefícios, que leva a negativas de proteção por razões ancilares, fulcradas na lei, em total descompasso e desrespeito à Constituição.

$\mathrm{O}$ que se procurou enfatizar com o presente estudo, até mesmo de forma persistente, diz respeito à conclusão nodal deste trabalho: o estudo dos benefícios previdenciários por incapacidade deve levar em conta o regime jurídico único, altamente protetivo, dos direitos humanos fundamentais sociais, de envergadura constitucional, cuja dinâmica leva, inexoravelmente, à sua universalização, tanto em termos de pessoas beneficiárias, como em termos de contingências sociais protegidas.

Tal é a chave interpretativa a reinar quando das análises dos diversos conflitos existentes em tal seara, como verdadeira lupa, como norte a guiar as soluções a serem apresentadas nos casos concretos.

Por isso tanto se falou, nesta obra, sobre a busca da máxima efetividade possível em termos de proteção ao direito humano fundamental à previdência social. 


\section{REFERÊNCIAS}

ABREU, João Paulo Pirôpo de. A autonomia financeira do Poder Judiciário: limites traçados pelo princípio da independência e harmonia dos Poderes. Brasília: Conselho da Justiça Federal, 2013.

AFONSO, Lívia de Paula Ziti. O papel do Poder Judiciário na efetividade dos direitos fundamentais sociais. 2010. Dissertação (Mestrado) - Faculdade de Direito, Universidade de São Paulo, São Paulo, 2010.

ALBUQUERQUE, Felipe Braga. Direito \& política: pressupostos para a análise de questões políticas pelo judiciário à luz do princípio democrático. Florianópolis: Conceito, 2013.

ALEXY, Robert. Teoria dos direitos fundamentais. Tradução de Virgílio Afonso da Silva. 2. ed. São Paulo: Malheiros Ed., 2011.

- Teoria discursiva do direito. Tradução de Alexandre Travessoni Gomes Trivisonno. Rio de Janeiro: Forense Universitária, 2014.

ALMANSA PASTOR, Jose Manuel. Derecho de la seguridad social. 7. ed. Madrid: Tecnos, 1991.

ALMEIDA, Luiz Antônio Freitas de. Direitos fundamentais sociais e ponderação: ativismo irrefletido e controle jurídico racional. Porto Alegre: Sérgio Antonio Fabris, 2014.

ALVES, Cleber Francisco. O princípio constitucional da dignidade da pessoa humana: o enfoque da doutrina social da igreja. Rio de Janeiro: Renovar; 2001.

AMADO, Frederico. Curso de direito e processo previdenciário. 6. ed. Salvador: JusPODIVM, 2015.

AMARAL JÚNIOR, José Levi Mello do (Org.). Estado de direito e ativismo judicial. 1. ed. São Paulo: Quartier Latin, 2010.

APPIO, Eduardo. Controle judicial das políticas públicas no Brasil. 1. ed. 4. reimp. Curitiba: Juruá, 2007.

ÁVILA, Humberto. Teoria dos princípios: da definição à aplicação dos princípios jurídicos. 12. ed. ampl. São Paulo: Malheiros Ed., 2011.

BADIN, Arthur. Controle judicial das políticas públicas: contribuição ao estudo do tema da judicialização da política pela abordagem da análise institucional comparada de Neil K. Komesar. São Paulo: Malheiros Ed., 2013. 
BAGGIO, Moacir Camargo. Jurisdição e previdência em tempos de crise de solidariedade. São Paulo: LTr, 2008.

BARCELlOS, Ana Paula de. A eficácia jurídica dos princípios constitucionais: o princípio da dignidade da pessoa humana. 3. ed. Rio de Janeiro: Renovar, 2011.

BARRETTO, Vicente de Paulo. Reflexões sobre os direitos sociais. In: SARLET, Ingo Wolfgang (Org.). Direitos fundamentais sociais: estudos de direito constitucional, internacional e comparado. Rio de Janeiro: Renovar, 2003.

BARROS, Sérgio Resende de. Contribuição dialética para o constitucionalismo. Campinas: Millennium, 2008.

BARROSO, Luís Roberto. Curso de direito constitucional contemporâneo. 4. ed. São Paulo: Saraiva, 2013.

. A dignidade da pessoa humana no direito constitucional contemporâneo. Belo Horizonte: Fórum, 2012.

. O direito constitucional e a efetividade de suas normas. 8. ed. Rio de Janeiro: Renovar, 2006.

. Temas de direito constitucional. 2. ed. Rio de Janeiro: Renovar, 2008. v. 3.

BATIFFOL, Henri. A filosofia do direito. Tradução Neide de Faria. São Paulo: Difusão Européia do Livro, 1968.

BATISTA, Flávio Roberto. Benefícios previdenciários por incapacidade no Regime Geral de Previdência Social. 2008. Dissertação (Mestrado) - Faculdade de Direito, Universidade de São Paulo, São Paulo, 2008.

BELTRAN, Ari Possidonio. Direito do trabalho e direitos fundamentais. São Paulo: LTr, 2002.

BITENCOURT, Caroline Müller. Controle jurisdicional de políticas públicas. Porto Alegre: Nuria Fabris, 2013.

BITENCOURT NETO, Eurico. O direito ao mínimo para uma existência digna. Porto Alegre: Livr. do Advogado, 2010.

BOBBIO, Norberto. A era dos direitos. Tradução Carlos Nelson Coutinho. 18. tir. Rio de Janeiro: Elsevier, 2004.

BONTEMPO, Alessandra Gotti. Direitos sociais em juízo: mecanismos de aferição de resultado e controle do retrocesso social. 2009. Tese (Doutorado) - Pontifícia Universidade Católica de São Paulo, São Paulo, 2009. 
BUCCI, Maria Paula Dallari. O conceito de política pública em direito. In: BUCCI, Maria Paula Dallari (Org.). Políticas públicas: reflexões sobre o conceito jurídico. São Paulo: Saraiva, 2006.

2006.

(Org.). Políticas públicas: reflexões sobre o conceito jurídico. São Paulo: Saraiva,

CAMPILONGO, Celso Fernandes. Direito e democracia. São Paulo: Max Limonad, 1997.

CAMPOS, Marcelo Barroso Lima Brito de. Curso de processo previdenciário. Curitiba: Juruá, 2013. v. 1.

CANELA JUNIOR, Osvaldo. Controle judicial de políticas públicas. São Paulo: Saraiva, 2011.

CANOTILHO, José Joaquim Gomes. Direito constitucional e teoria da Constituição. 7. ed. 11. reimp. Coimbra: Almedina, 2003.

CARBONELL, Miguel. Teoría del neoconstitucionalismo: ensayos escogidos. Madrid: Trotta, 2007.

CASTILHO, Ricardo. Direitos humanos: processo histórico - evolução no mundo, direitos fundamentais: constitucionalismo contemporâneo. São Paulo: Saraiva, 2010.

CASTRO, Carlos Alberto Pereira de; LAZZARI, João Batista. Manual de direito previdenciário. 16. ed. Rio de Janeiro: Forense, 2014.

CERQUEIRA, Marcello. A Constituição na história: origem \& reforma. Rio de Janeiro: Revan, 1993.

CESARINO JUNIOR, Antônio Ferreira. Direito social. São Paulo: LTr, 1980.

CONCEIÇÃO, Apelles J. B. Segurança social: manual prático. 8. ed. Coimbra: Almedina, 2008.

CORREIA, Marcus Orione Gonçalves. Direito adquirido social. Revista do Advogado, São Paulo, v. 24, n. 80, p. 45-54, Nov. 2004.

. Legislação previdenciária comentada. 2. ed. São Paulo: DPJ, 2009.

; CORREIA, Érica Paula Barcha. Curso de direito da seguridade social. 6. ed. São Paulo: Saraiva, 2012.

CRUZ, Rômulo Lago e (Org.). A realização do espaço constitucional. São Luís: Faculdade São Luís, 2004.

CUTAIT NETO, Michel. Auxílio-doença. Leme: J.H. Mizuno, 2006. 
DAHL, Robert Alan. Democracy and its critics. New Haven: Yale University Press, 1989.

DALLARI, Dalmo de Abreu. A Constituição na vida dos povos. São Paulo: Saraiva, 2010.

DE LUCCA, Newton; MEYER-PFLUG, Samantha Ribeiro; NEVES, Mariana Barboza Baeta (Orgs.). Direito constitucional contemporâneo. São Paulo: Quartier Latin, 2012.

DERBLI, Felipe. O princípio da proibição de retrocesso social na Constituição de 1988. 1. ed. Rio de Janeiro: Renovar, 2007.

DIAS, Eduardo Rocha; MACÊDO, José Leandro Monteiro de. Curso de direito previdenciário. 3. ed. São Paulo: Método, 2012.

DIDIER JUNIOR, Fredie. Curso de direito processual civil. 14. ed. Salvador: JusPODIVM, 2012. v. 1.

; BRAGA, Paula Sarno; OLIVEIRA, Rafael. Curso de direito processual civil. 7. ed. Salvador: JusPODIVM, 2012. v. 2.

DINAMARCO, Candido Rangel. Instituições de direito processual civil. 4. ed. São Paulo: Malheiros Ed., 2004. v. 1, v. 2 e v. 3.

. A instrumentalidade do processo. 15.ed. São Paulo: Malheiros ed., 2013.

DUGUIT, León. Fundamentos do direito. Tradução Márcio Pugliesi. 2. ed. São Paulo: Ícone, 2006.

. Las transformaciones del derecho (público y privado). Traducido del francês por Adolfo G. Posada y Ramón Jaén. Buenos Aires: Heliasta, [2001].

FACHIN, Melina Girardi. Universalismo versus relativismo: superação do debate maniqueísta acerca dos fundamentos dos direitos humanos. In: PIOVESAN, Flávia; IKAWA, Daniela (Coords.). Direitos humanos: fundamento, proteção e implementação; perspectivas e desafios contemporâneos. Curitiba: Juruá, 2008. v. 2, p. 75-93.

FARIA, José Eduardo. Justiça e conflito: os juízes em face dos novos movimentos sociais. 2. ed., rev. e ampl. São Paulo: Ed. Revista dos Tribunais, 1992.

(Org.). Direitos humanos, direitos sociais e justiça. 1. ed. 3. tir. São Paulo: Malheiros Ed., 2002.

FARIAS, Luciana Moraes de. Auxílio-acidente. São Paulo: LTr, 2012.

FERRAJOLI, Luigi. Por uma teoria dos direitos e dos bens fundamentais. Tradução de Hermes Zaneti Jr. Porto Alegre: Livr. do Advogado, 2011. 
FERREIRA FILHO, Manoel Gonçalves. Direitos humanos fundamentais. 13. ed. São Paulo: Saraiva, 2011.

FIRMINO, Nelson Flávio. Curso de direitos fundamentais. Curitiba: Juruá, 2013.

FREIRE JÚNIOR; Américo Bedê. O controle judicial de políticas públicas. São Paulo: Ed. Revista dos Tribunais, 2005.

GALDINO, Flávio. Introdução à teoria dos custos dos direitos: direitos não nascem em árvores. Rio de Janeiro: Lumen Juris, 2005.

GALVÃO, Jorge Octávio Lavocat. O neoconstitucionalismo e o fim do Estado de Direito. 2012. Tese (Doutorado) - Faculdade de Direito, Universidade de São Paulo, São Paulo, 2012.

GARGARELLA, Roberto. La justicia frente al gobierno: sobre el carácter contramayoritario del poder judicial. Barcelona: Ariel, 1996.

. Theories of democracy, the judiciary and social rights. In: GARGARELLA, Roberto; DOMINGO, Pilar; ROUX, Theunis (Orgs.). Courts and social transformation in new democracies: an institutional voice for the poor. London: Ashgate Publishing Limited, 2006.

; DOMINGO, Pilar; ROUX, Theunis (Orgs.). Courts and social transformation in new democracies: an institutional voice for the poor. London: Ashgate Publishing Limited, 2006.

GLOPPEN, Siri et al. Courts and power in Latin America and Africa. New York: Palgrave Macmillan, 2010.

GOMES, Dinaura Godinho Pimentel. Direito do trabalho e dignidade da pessoa humana, no contexto da globalização econômica: problemas e perspectivas. São Paulo: LTr, 2005.

GONÇALVES, Cláudia Maria da Costa. Direitos fundamentais sociais: releitura de uma constituição dirigente. Curitiba: Juruá, 2010.

GRINOVER, Ada Pellegrini; WATANABE, Kazuo (Orgs.). O controle jurisdicional de políticas públicas. 1. ed. Rio de Janeiro: Forense, 2011.

GURVITCH, Georges. L’idée du droit social. Paris: Scientia Verlag Aalen, 1972.

HABERMAS, Jürgen. Um ensaio sobre a Constituição da Europa. Tradução Marian Toldy e Teresa Toldy. 1. ed. Lisboa: Edições 70, 2012.

HEGEL, Georg Wilhelm Friedrich. Princípios da filosofia do direito. Tradução Orlando Vitorino. São Paulo: Martins Fontes, 2000. 
HERRERA, Carlos Miguel. Estado, Constituição e direitos sociais. In: SOUZA NETO, Claudio Pereira de; SARMENTO, Daniel (Orgs.). Direitos sociais: fundamentos, judicialização e direitos sociais em espécie. Rio de Janeiro: Lumen Juris, 2008.

HESSE, Konrad. Constituição e direito constitucional. In: HESSE, Konrad. Temas fundamentais do direito constitucional. Tradução Carlos dos Santos Almeida, Gilmar Ferreira Mendes e Inocêncio Mártires Coelho. São Paulo: Saraiva, 2009.

. Elementos de direito constitucional da República Federal da Alemanha. Tradução da 20. ed. alemã. Porto Alegre: Sergio Antonio Fabris, 1998.

A força normativa da Constituição. Tradução de Gilmar Ferreira Mendes. Porto Alegre: Sergio Antonio Fabris, 1991.

. A interpretação constitucional. In: HESSE, Konrad. Temas fundamentais do direito constitucional. Tradução Carlos dos Santos Almeida, Gilmar Ferreira Mendes e Inocêncio Mártires Coelho. São Paulo: Saraiva; 2009. p. 108-116.

HONNETH, Axel. Luta por reconhecimento: a gramática moral dos conflitos sociais. Tradução Luiz Repa. 1. ed. São Paulo: Ed. 34, 2003.

HORVATH JÚNIOR, Miguel. Direito previdenciário. 9. ed. São Paulo: Quartier Latin, 2012.

HUBERMAN, Leo. História da riqueza do homem. Tradução de Waltensir Dutra. 8. ed. Rio de Janeiro: ZAHAR, 1972.

IBRAHIM, Fábio Zambitte. Curso de direito previdenciário. 16. ed. Niterói: Ímpetus, 2011.

JACOB, Cesar Augusto Alckmin. A "reserva do possível": obrigação de previsão orçamentária e de aplicação da verba. In: GRINOVER, Ada Pellegrini; WATANABE, Kazuo (Orgs.). O controle jurisdicional de políticas públicas. 1. ed. Rio de Janeiro: Forense, 2011.

JOAS, Hans. A sacralidade da pessoa: nova genealogia dos direitos humanos. Tradução Nélio Schneider. São Paulo: Unesp, 2012.

JORGE NETO, Nagibe de Melo. O controle jurisdicional das políticas públicas: concretizando a democracia e os direitos sociais fundamentais. Salvador: JusPODIVM, 2008.

KELBERT, Fabiana Okchstein. Reserva do possível e a efetividade dos direitos sociais no direito brasileiro. Porto Alegre: Livr. do Advogado, 2011. 
KELSEN, Hans. A democracia. Tradução de Ivone Castilho Benedetti, Jefferson Luiz Camargo, Marcelo Brandão Cipolla $e$ Vara Barkow. 2. ed. São Paulo: Martins Fontes, 2000.

. Teoria pura do direito. Tradução João Baptista Machado. 6. ed., 3 tir. São Paulo: Martins Fontes, 1999.

KOMESAR, Neil K. Imperfect alternatives: choosing Institutions in law, economics, and public policy. Chicago: The University of Chicago Press, 1996.

LAFER, Celso. A reconstrução dos direitos humanos: um diálogo com o pensamento de Hannah Arendt. 6. reimp. São Paulo: Companhia das Letras, 2006.

LASSALLE, Ferdinand. A essência da Constituição. Prefácio e organização Aurélio Wander Bastos. 9. ed. Rio de Janeiro: Freitas Bastos, 2014.

LAZARI, Rafael José Nadim de. Reserva do possível e mínimo existencial: a pretensão da eficácia da norma constitucional em face da realidade. Curitiba: Juruá, 2012.

LENZA, Pedro. Direito constitucional esquematizado. 18. ed. São Paulo: Saraiva, 2014.

LEWANDOWSKI, Enrique Ricardo. Proteção dos direitos humanos na ordem interna e internacional. 1. ed. Rio de Janeiro: Forense, 1984.

LOPES, José Reinaldo de Lima. Direito subjetivo e direitos sociais: o dilema do Judiciário no Estado Social de Direito. In: FARIA, José Eduardo (Org.). Direitos humanos, direitos sociais e justiça. 1. ed. 5. tir. São Paulo: Malheiros Ed., 2010. p. 113-143.

. Direitos sociais: teoria e prática. São Paulo: Método, 2006.

MARMELSTEIN, George. Curso de direitos fundamentais. 4. ed. São Paulo: Atlas, 2013.

MARTIGNAGO, Gisella. Controle de constitucionalidade e o ativismo judicial. 2009. Dissertação (Mestrado) - Faculdade de Direito, Universidade de São Paulo, São Paulo, 2009.

MARTINEZ, Wladimir Novaes. Auxílio-acidente. São Paulo: LTr, 2006.

. Curso de direito previdenciário. 6. ed. São Paulo: LTr, 2014.

. Princípios de direito previdenciário. 5. ed. São Paulo: LTr, 2011.

MARTINS, Sérgio Pinto. Direito da seguridade social. 34. ed. São Paulo: Atlas, 2014.

Direitos fundamentais trabalhistas. São Paulo: Atlas, 2008. 
MASSUD, Leonardo. Universalismo e relativismo cultural. In: PIOVESAN, Flávia; IKAWA, Daniela (Coords.). Direitos humanos: fundamento, proteção e implementação; perspectivas e desafios contemporâneos. Curitiba: Juruá, 2008. v. 2, p. 59-73.

MAUSS, Marcel. Sociologia e antropologia. Tradução de Paulo Neves. São Paulo: Cosac \& Naify, 2003.

MAZOTTI, Marcelo. Jurisdição constitucional e ativismo judiciário: análise comparativa entre a atuação do Supremo Tribunal Federal brasileiro e da Suprema Corte estadunidense. São Paulo: USP, 2012. Dissertação (Mestrado) - Faculdade de Direito, Universidade de São Paulo, São Paulo, 2012.

MELLO, Celso Antônio Bandeira de. Eficácia das normas constitucionais e direitos sociais. 1. ed. 3. tir. São Paulo: Malheiros Ed., 2011.

MENDONÇA, Eduardo. Da faculdade de gastar ao dever de agir: o esvaziamento contramajoritário de políticas públicas. In: SOUZA NETO, Claudio Pereira de; SARMENTO, Daniel (Orgs.). Direitos sociais: fundamentos, judicialização e direitos sociais em espécie. Rio de Janeiro: Lumen Juris, 2008.

MINISTÉRIO DA PREVIDÊNCIA SOCIAL. Agendamento. Disponível em: $<$ http://www.previdencia.gov.br/servicos-ao-cidadao/todos-os-servicos/agendamento/>. Acesso em: 15 set. 2015.

MIRANDA, Jorge. Manual de direito constitucional. 3. ed. Coimbra: Coimbra Ed., 2000. v. 4.

MOHNHAUPT, Heinz; GRIMM, Dieter; Constituição: história do conceito desde a antiguidade até nossos dias. Tradução Peter Naumann. Belo Horizonte: Tempus, 2012.

MORAES, Alexandre de. Direito constitucional. 23. ed. São Paulo: Atlas, 2008.

. Direitos humanos fundamentais. 9. ed. São Paulo: Atlas, 2011.

. Jurisdição constitucional e tribunais constitucionais: garantia suprema da Constituição. 3. ed. São Paulo: Atlas, 2013.

MORAIS, Jose Luis Bolzan de. A ideia de direito social: o pluralismo jurídico de Georges Gurvitch. Porto Alegre: Livr. do Advogado, 1997.

MOREIRA, Alinie da Matta. As restrições em torno da reserva do possível: uma análise crítica. Belo Horizonte: Fórum, 2011.

MORRIS, Clarence (Org.). Os grandes filósofos do direito. Tradução de Reinaldo Guarany. São Paulo: Martins Fontes, 2002. 
NASSAR, Elody Boulhosa. Previdência social na era do envelhecimento. São Paulo: Saraiva, 2013.

NERY JÚNIOR, Nelson; NERY, Rosa Maria de Andrade. Código de Processo Civil comentado. 9. ed. São Paulo: Ed. Revista dos Tribunais, 2006.

NOBRE, Marcos (Org.). Curso livre de teoria crítica. Campinas: Papirus, 2008.

NOVAIS, Jorge Reis. Direitos sociais: teoria jurídica dos direitos sociais enquanto direitos fundamentais. 1. ed. Coimbra: Coimbra Ed., 2010.

OLIVEIRA, Fernando Fróes. Direitos sociais, mínimo existencial e democracia deliberativa. Rio de Janeiro: Lumen Juris, 2013.

OLIVEIRA, Márcio Luís de. A Constituição juridicamente adequada: transformações do constitucionalismo e atualização principiológica dos direitos, garantias e deveres fundamentais. Belo Horizonte: Arraes, 2013.

ORGANIZAÇÃO INTERNACIONAL DO TRABALHO. Disponível em: $<$ http://www.oitbrasil.org.br/node/468>.

PASSOS, Daniel Silva. Intervenção judicial nas políticas públicas: o problema da legitimidade. São Paulo: Saraiva, 2014.

PEREIRA, Caio Mário da Silva. Instituições de direito civil. 18. ed. Rio de Janeiro: Forense, 2004. v. 4.

PEREIRA, Milena Carla Azzolini. Direitos humanos no século XXI: a redução da pobreza e a proteção dos direitos sociais na Constituição Federal de 1988. 2010. Dissertação (Mestrado) - Pontifícia Universidade Católica de São Paulo - PUC/SP, São Paulo, 2010.

PESSOA, Flávia Moreira Guimarães. Curso de direito constitucional do trabalho: uma abordagem à luz dos direitos fundamentais. Salvador: JusPODIVM, 2009.

PINTO, Airton Pereira. Direito do trabalho, direitos humanos sociais e a Constituição Federal. 1. ed. São Paulo: LTr, 2006.

PIOVESAN, Flávia. Direitos humanos e o direito constitucional internacional. 9. ed. São Paulo: Saraiva, 2008.

Proteção internacional dos direitos econômicos, sociais e culturais. In: SARLET, Ingo Wolfgang (Org.). Direitos fundamentais sociais: estudos de direito constitucional, internacional e comparado. Rio de Janeiro, Renovar, 2003. 
PIOVESAN, Flávia; IKAWA, Daniela (Coords.). Direitos humanos: fundamento, proteção e implementação; perspectivas e desafios contemporâneos. Curitiba: Juruá, 2008. v. 2.

RAMOS, André de Carvalho. Teoria geral dos direitos humanos na ordem internacional. 2. ed. São Paulo: Saraiva, 2012.

RAMOS, Elival da Silva. Ativismo judicial: parâmetros dogmáticos. 1. ed. São Paulo: Saraiva, 2010.

RIBEIRO, Fernando José Armando. Constitucionalismo e teoria do direito. Belo Horizonte: Del Rey, 2013.

RICARDO, Carolina de Mattos. Reflexões kantianas na construção histórica dos direitos humanos. In: PIOVESAN, Flávia; IKAWA, Daniela (Coords.). Direitos humanos: fundamento, proteção e implementação; perspectivas e desafios contemporâneos. Curitiba: Juruá, 2008. v. 2.

RIDOLA, Paolo. A dignidade humana e o "princípio liberdade” na cultura constitucional europeia. Tradução Carlos Luiz Strapazzon e Tula Wesendonck. Porto Alegre: Livr. do Advogado, 2014.

ROCHA, Daniel Machado da; BALTAZAR JÚNIOR, José Paulo. Comentários à Lei de benefícios da previdência social. 7. ed. Porto Alegre: Livr. do Advogado, 2007. 2014. v. 1.

; SAVARIS, José Antonio. Curso de direito previdenciário. Curitiba: Alteridade,

RUBIN, Fernando. Benefícios por incapacidade no Regime Geral da Previdência Social. Porto Alegre: Livr. do Advogado, 2014.

SAMPAIO, José Adércio Leite. Teoria da Constituição e dos direitos fundamentais. Belo Horizonte: Del Rey, 2013.

SAMPAIO, Marcos. O conteúdo essencial dos direitos sociais. São Paulo: Saraiva, 2013.

SANTOS, Marisa Ferreira dos. Direito previdenciário esquematizado. 3. ed. São Paulo: Saraiva, 2013.

SARLET, Ingo Wolfgang. Dignidade da pessoa humana e direitos fundamentais na Constituição Federal de 1988. 5. ed. Porto Alegre: Livr. do Advogado, 2007. 2007. . A eficácia dos direitos fundamentais. 8. ed. Porto Alegre: Livr. do Advogado, ; MARINONI, Luiz Guilherme; MITIDIERO, Daniel. Curso de direito constitucional. 1. ed. 2. tir. São Paulo: Ed. Revista dos Tribunais, 2012. 
SARLET, Ingo Wolfgang; TIMM, Luciano Benetti (Orgs.). Direitos fundamentais, orçamento e "reserva do possível”. 2. ed. Porto Alegre: Livr. do Advogado, 2010.

(Org.). Direitos fundamentais sociais: estudos de direito constitucional, internacional e comparado. Rio de Janeiro: Renovar, 2003.

SARMENTO, Daniel. Por um constitucionalismo inclusivo: história constitucional brasileira, teoria da Constituição e direitos fundamentais. Rio de Janeiro: Lumen Juris, 2010.

SAVARIS, José Antonio. Direito processual previdenciário. 4. ed. Curitiba: Juruá, 2012.

SCHÄFER, Jairo. Classificação dos direitos fundamentais: do sistema geracional ao sistema unitário. 2. ed. Porto Alegre: Livr. do Advogado, 2013.

SCHWARZ, Rodrigo Garcia. Os direitos sociais e a sindicabilidade judicial das políticas públicas sociais no Estado Democrático de Direito. São Paulo: LTr, 2013.

SERAU JUNIOR, Marco Aurélio. Curso de processo judicial previdenciário. 4. ed. São Paulo: Método, 2014.

SILVA, José Afonso da. Curso de direito constitucional positivo. 34. ed. São Paulo: Malheiros Ed., 2011.

SILVA, Sandoval Alves da. Direitos sociais: leis orçamentárias como instrumento de implementação. Curitiba: Juruá, 2007.

SILVA, Virgílio Afonso da. Direitos fundamentais: conteúdo essencial, restrições e eficácia. 2. ed. 2 tir. São Paulo: Malheiros Ed., 2011.

SIMM, Zeno. Os direitos fundamentais e a seguridade social. São Paulo: LTr, 2005.

SIMÕES, Carlos. Teoria \& crítica dos direitos sociais: o Estado Social e o Estado Democrático de Direito. São Paulo: Cortez, 2013.

SOARES, Ricardo Maurício Freire. O princípio constitucional da dignidade da pessoa humana. São Paulo: Saraiva, 2010.

SOUZA NETO, Cláudio Pereira de; SARMENTO, Daniel. Direito constitucional: teoria, história e métodos de trabalho. Belo Horizonte: Fórum, 2013.

(Orgs.). Direitos sociais: fundamentos, judicialização e direitos sociais em espécie. 1. ed. Rio de Janeiro: Lumen Juris, 2008.

SUPIOT, Alain. Critique du droit du travail. Paris: PUF, 2007. 
TAVARES, Marcelo Leonardo. O devido processo legal previdenciário e as presunções de prova. In: TAVARES, Marcelo Leonardo et al. (Coords.). Direito processual previdenciário: temas atuais. Niterói: Ímpetus, 2009.

TAVARES, Marco Aurélio Romagnoli. Ativismo judicial e políticas públicas. Porto Alegre: Sérgio Antonio Fabris, 2011.

THEODORO JÚNIOR, Humberto. Curso de direito processual civil. 43. ed. Rio de Janeiro: Forense, 2005. v. 1.

TORRES, Ricardo Lobo. O direito ao mínimo existencial. Rio de Janeiro: Renovar, 2009.

TRINDADE, Antônio Augusto Cançado. Tratado de direito internacional dos direitos humanos. 1. ed. Porto Alegre: Sergio Antonio Fabris, 1997. v. 1.

VIDA SORIA, José et al. Manual de seguridad social. 7. ed. Madrid: Tecnos, 2011.

VIDAL NETO, Pedro. Natureza jurídica da seguridade social. 1993. Tese (Titular de Direito do Trabalho) - Faculdade de Direito, Universidade de São Paulo, São Paulo, 1993.

VIEIRA, Oscar Vilhena. Direitos fundamentais: uma leitura da jurisprudência do STF. São Paulo: Malheiros Ed., 2006.

WEFFORT, Francisco Correa (Org.). Os clássicos da política. São Paulo: Ática, 2006. v. 2.

ZUBA, Thais Maria Riedel de Resende. O direito previdenciário e o princípio da vedação do retrocesso. São Paulo: LTr, 2013. 